\title{
Preparation of $\alpha, \beta$-unsaturated trifluoromethylketones and their application in the synthesis of heterocycles
}

\author{
Valentine G. Nenajdenko* and Elizabeth S. Balenkova \\ Department of Chemistry, Moscow State University, Leninskie Gory, Moscow 119992, Russia \\ E-mail:nen@acylium.chem.msu.ru
}

\begin{abstract}
The review is devoted to the preparation of $\alpha, \beta$-unsaturated trifluoromethyl ketones and the application of these building blocks in the synthesis of three- to seven-membered fluorinated heterocycles. The literature up to 2010 is highlighted.
\end{abstract}

Keywords: Fluorine, heterocycle, trifluoromethyl group, synthesis, $\alpha, \beta$-unsaturated $\mathrm{CF}_{3}$-ketones

\section{Table of Contents}

1. Introduction

2. Synthesis of $\alpha, \beta$-Unsaturated Trifluoromethylketones

2.1. Synthesis of enones

2.1.1 Trifluoroacylation of alkenes, acetylenes and dienes

2.1.2 Trifluoroacylation of organometallics

2.1.3 Condensations and similar reactions

2.1.4 Nucleophilic substitution at the $\beta$-position

2.1.5 Modification of the $\alpha$-position

2.1.6 Other methods

2.2. Synthesis of acetylenic $\mathrm{CF}_{3}$-ketones

3. Application of $\alpha, \beta$-Unsaturated $\mathrm{CF}_{3}$-Ketones in the Synthesis of Heterocycles

3.1. Synthesis of three- and four-membered heterocycles

3.1.1 Synthesis of pyrrole derivatives

3.1.2 Synthesis of furan derivatives

3.1.3 Synthesis of thiophene derivatives

3.1.4 Synthesis of pyrazoles and their derivatives

3.1.5 Synthesis of isoxazole (isoselenazole) derivatives

3.1.6 Synthesis of oxazoles

3.1.7 Synthesis of triazoles

3.2. Synthesis of six-membered heterocycles

3.2.1 Synthesis of pyridines and their derivatives 
3.2.2 Synthesis of quinolines and benzoquinolines

3.2.3 Synthesis of pyrans, thiopyrans and their derivatives

3.2.4 Synthesis of pyrimidines and their derivatives

3.2.5 Synthesis of 1,2- , 1,3- and 1,4-thiazines

3.2.6 Synthesis of 1,3-oxazines and 1,2,3-oxathiazines

3.3. Synthesis of seven-membered heterocycles

3.3.1 Synthesis of 1,4-diazepines (benzoanalogues) and 1,5-benzoxazepines

3.4. Synthesis of other condensed heterocycles

4. Conclusion

5. References

\section{Introduction}

The trifluoromethyl group is a very important substituent in medicinal chemistry, due to its unique stereoelectronic properties. A trifluoromethyl group usually increases the lipophilicity of a molecule, improving its transport characteristics in vivo. Furthermore, the strength and durability of the C-F bond compared with the $\mathrm{C}-\mathrm{H}$ bond (116 and $100 \mathrm{kcal} / \mathrm{mol}$ respectively) allows undesirable metabolic transformations to be avoided. So the introduction of trifluoromethyl groups into bioactive molecules has become very important in pharmaceutical studies, stimulating work directed towards the elaboration of synthetic methodology for compounds containing trifluoromethyl groups. Because of all these factors, organofluorine chemistry has been vigorously developing during the past two decades.

Most of the known approaches to the synthesis of $\mathrm{CF}_{3}$-containing organic compounds suffer from serious drawbacks. First of all, the starting materials required for these methods are rather difficult to obtain, or they are fairly toxic and inconvenient to work with. Additionally, methods for direct fluorination and trifluoromethylation do not always allow the introduction of the $\mathrm{CF}_{3}$-group at the required position of a molecule. As a result the more flexible "synthon" approach, based on the application of simple and readily available fluorine-containing compounds gains substantial interest. $\alpha, \beta$-Unsaturated trifluoromethyl ketones are easily available compounds which can be prepared by various methods ${ }^{1}$ and fairly convenient building blocks to prepare heterocyclic compounds containing a trifluoromethyl group.

\section{Synthesis of $\alpha, \beta$-Unsaturated Trifluoromethylketones}

\subsection{Synthesis of enones}

2.1.1 Trifluoroacylation of alkenes, acetylenes and dienes. Activated alkenes 1 can be trifluoroacetylated with trifluoroacetic acid anhydride (TFAA). This is a widely applied method due to its simplicity and adaptability for a wide range of substrates such as vinyl ethers ${ }^{2}$ vinyl sulfides, ${ }^{3}$ 
ketene dithioacetals, vinyl tellurides, ${ }^{4}$ vinyl amides, cyclic enamines, ${ }^{5}$ O-vinyloximes, ${ }^{6}$ and some activated dienes. $^{7}$

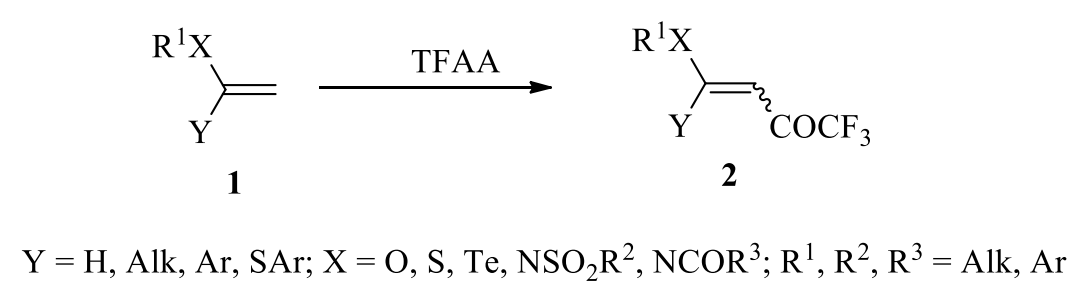

\section{Scheme 1}

Orthoacetates, ${ }^{8}$ acetals and trithioorthoacetates $\mathbf{3}$ react with excess trifluoroacetic anhydride with elimination of alkyl or aryl trifluoroacetate (thioacetate) to give trifluoromethyl enones $\mathbf{4}$, i.e., they are transformed into the corresponding activated alkenes in situ.

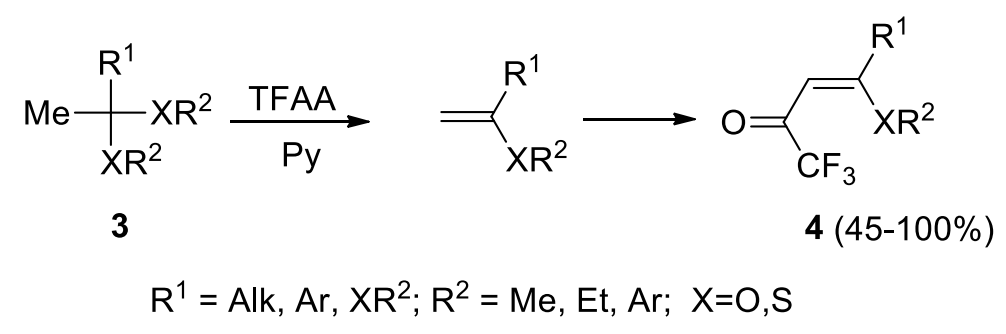

\section{Scheme 2}

Under higher temperature the reactions of vinyl ethers $\mathbf{5}$ with a threefold excess of TFAA in the presence of pyridine result in the formation of diones $\mathbf{6}$ in high yields. ${ }^{9}$

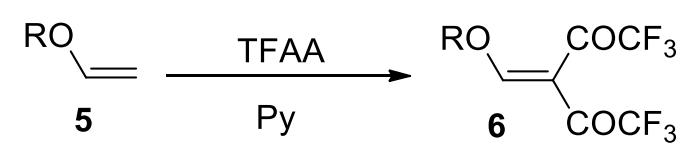

\section{Scheme 3}

Chloro(bromo) anhydrides of perfluoro carboxylic acids 7 can be also applied for acylation of alkenes 8. ${ }^{10}$ Trifluoroacylation of 1,1-dichloroethene $\mathbf{1 0}$ is performed with trifluoroacetyl bromide and chloride 7 in the presence of aluminum halides because of low double bond activity. ${ }^{11}$ Noteworthy using $\mathrm{AlBr}_{3}$ the only product formed is 2,2-dibromovinyltrifluoromethyl ketone 11b, whereas $\mathrm{AlCl}_{3}$ gives the corresponding dichloroketone 11a. 

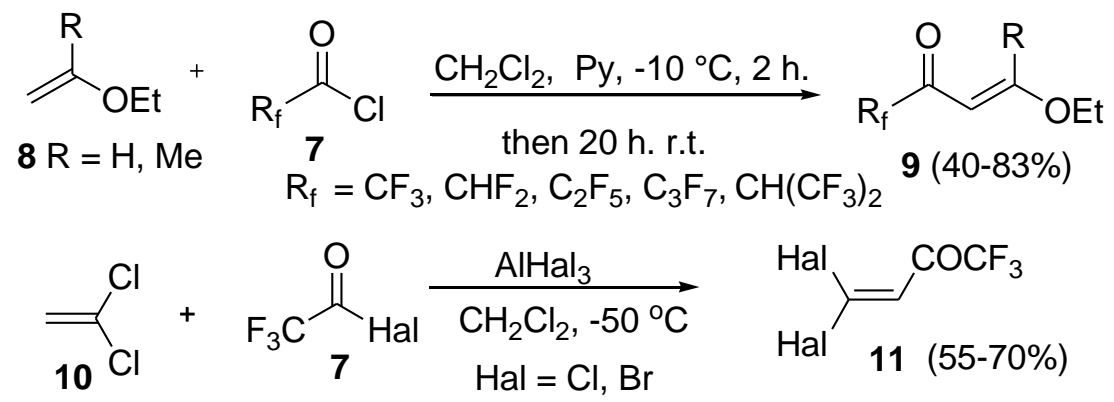

\section{Scheme 4}

As a rule trifluoroacetylation of enamines leads to a complex mixture of products. However, less reactive 1-morpholinocyclohept-1-ene 12 gave doubly trifluoroacetylated product 13. Trifluoroacetylimidazole ${ }^{12} 14$ and the complex 16 prepared from 4-dimethylaminopyridine ${ }^{13}$ gave better results. ${ }^{14}$

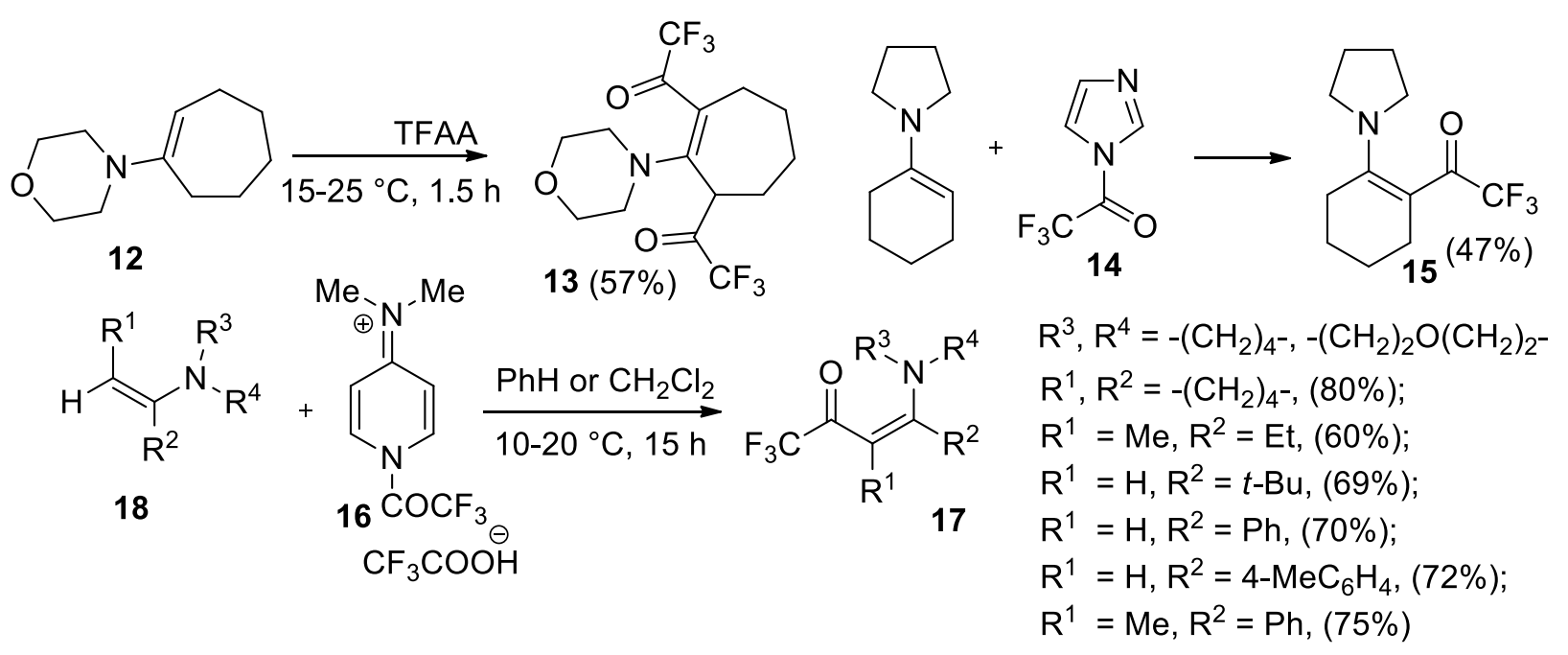

\section{Scheme 5}

It was demonstrated that $\mathrm{N}$-oxides 19 of tertiary amines can be transformed into $\mathrm{CF}_{3}$-enones $\mathbf{2 0}$ under treatment with TFAA via intermediate enamine formation. This reaction is called PotierPolonovski rearrangement and has been applied for synthesis of alkaloids $22 .{ }^{15}$

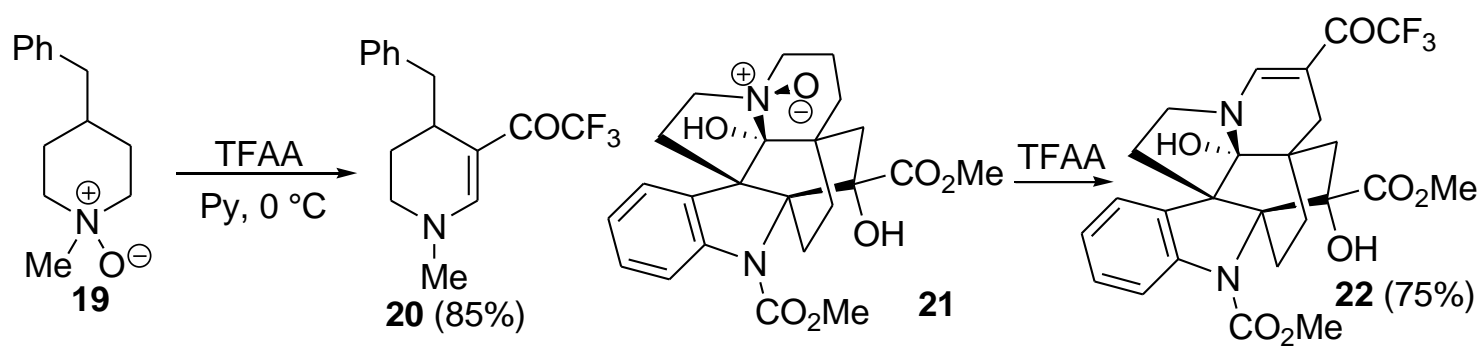

\section{Scheme 6}


The reaction of triethylamine with trifluoroacetyl chloride 24 at $-30{ }^{\circ} \mathrm{C}$ leads to 4-diethylamino1,1,1-trifluorobut-3-en-2-one $\mathbf{2 3}$. $^{16}$

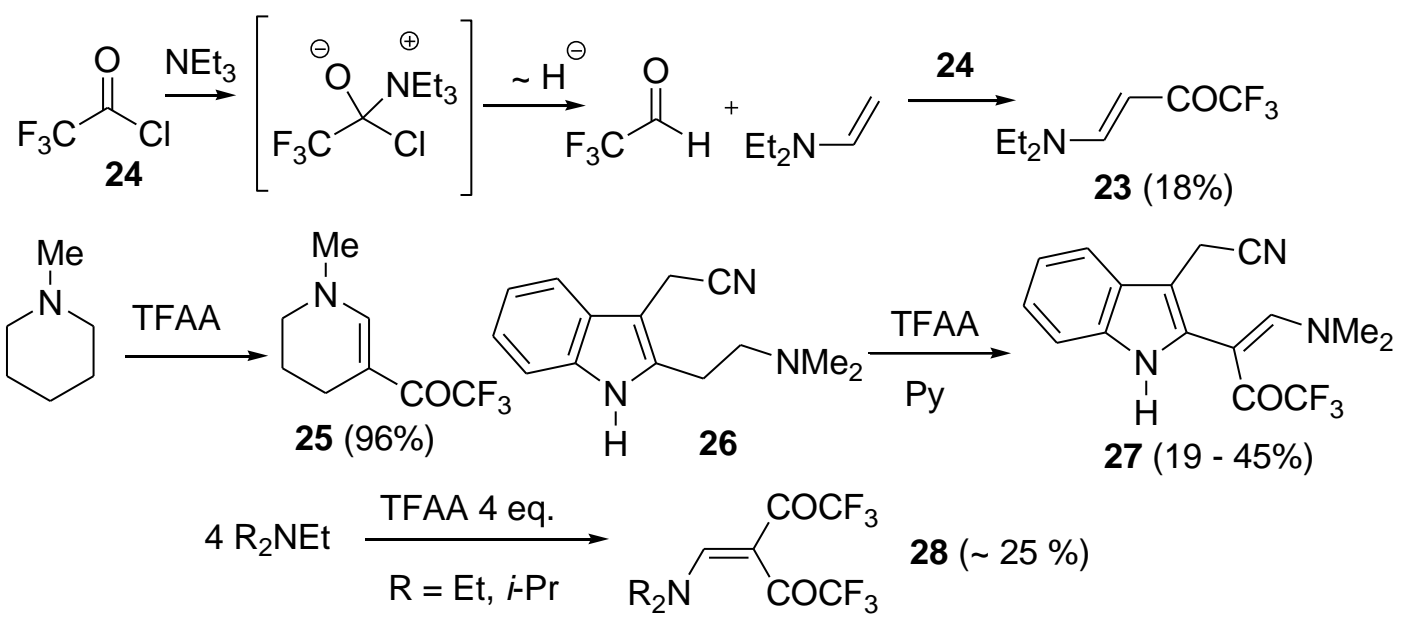

\section{Scheme 7}

The proposed reaction mechanism includes oxidation of triethylamine by one equivalent of trifluoroacetyl chloride to give diethyl(vinyl)amine and the subsequent trifluoroacylation. Cyclic amines react in a similar way, for example, N-methylpiperidine is converted into enaminone 25 in 96\% yield. Iso-tryptamine 26 can be trifluoroacetylated with TFAA to form enone $27 .{ }^{17}$ The reaction of triethylamine or diisopropylethylamine with TFAA leads to doubly trifluoroacetylated products $28 .^{18}$

Several examples for trifluoroacylation of enamides generated in situ from N-protected prolines 29 are known. The corresponding cyclic enaminoketones 30 were obtained in moderate to good yields. N-tosylpyrroline-2 $\mathbf{3 1}$ reacts with TFAA and salen-manganese complex $\mathbf{3 2}$ as the catalyst to give cyclic enaminonone 33 in moderate yield. ${ }^{19}$ The derivative of 5-hydroxypyrrolidin-2-one $\mathbf{3 4}$ can be converted to enamide $\mathbf{3 5}$ under treatment with acetic anhydride. However, the formation of heterocyclic enaminoketone $\mathbf{3 6}$ is observed under treatment with more electrophilic TFAA. ${ }^{20}$ 


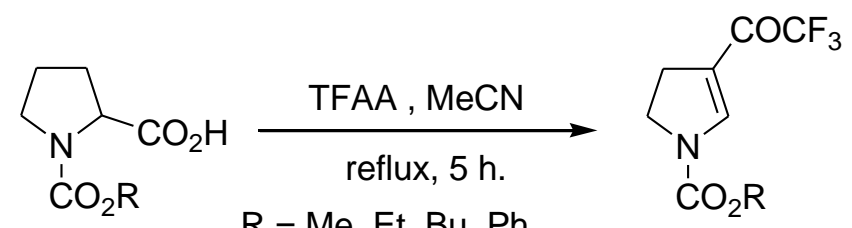

29

$\mathrm{R}=\mathrm{Me}, \mathrm{Et}, \mathrm{Bu}, \mathrm{Ph}$,

$30(34-68 \%)$

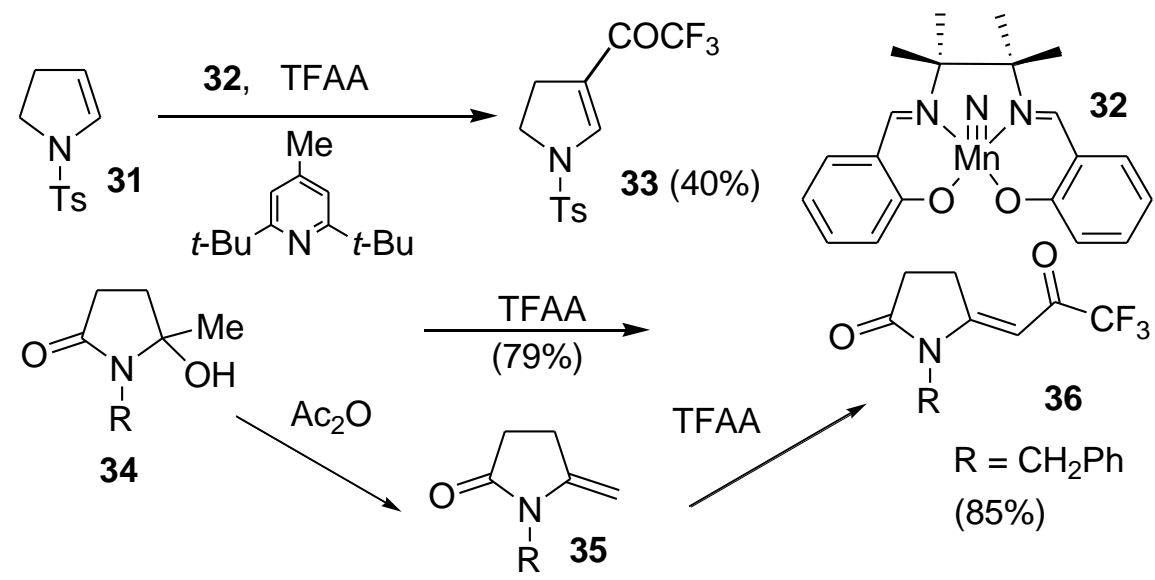

\section{Scheme 8}

The unusual disubstituted $\mathrm{CF}_{3}$-derivative of fulvene $\mathbf{3 7}$ was obtained by trifluoroacylation of cyclopentadiene with TFAA at room temperature using dimethylformamide as a solvent. ${ }^{21}$

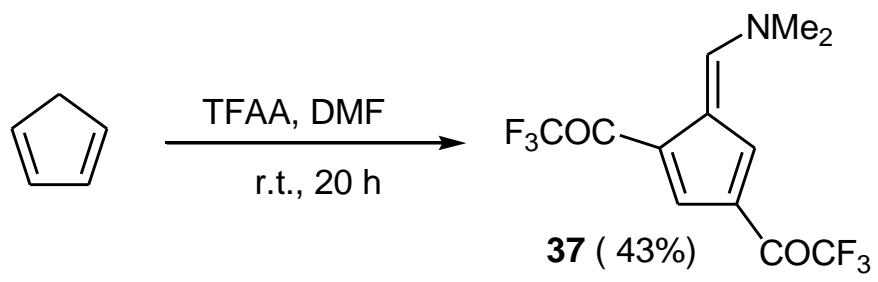

\section{Scheme 9}

The electrophilicity of trifluoroacetic anhydride and other derivatives of trifluoroacetic acid is insufficient for trifluoroacetylation of non-activated alkenes. ${ }^{22}$ The attempts of activation with Lewis acids were successful only for trifluoroacylation of aromatic compounds. However, TFAA can be activated by $\mathrm{Me}_{2} \mathrm{~S}_{-}-\mathrm{BF}_{3}$ complex. The trifluoroacylation in this case proceeds with alkenes able to form benzyl, allyl, cyclopropyl or tertiary cations. Arylsubstituted alkynes $\mathbf{3 8}$ can be trifluoroacylated as well to give sulfonium salts 39. ${ }^{23}$ The demethylation of these salts results in the formation of enones $\mathbf{4 0}$. Subsequent oxidation of $\mathbf{4 0}$ by hydrogen peroxide makes it possible to synthesize sulfones $\mathbf{4 1}$. Alternatively sulfides $\mathbf{4 2}$ can be prepared by the Pt-catalyzed regioselective trifluoroacetylthiolation of alkynes using thioesters $\mathbf{4 3}{ }^{24}$ 


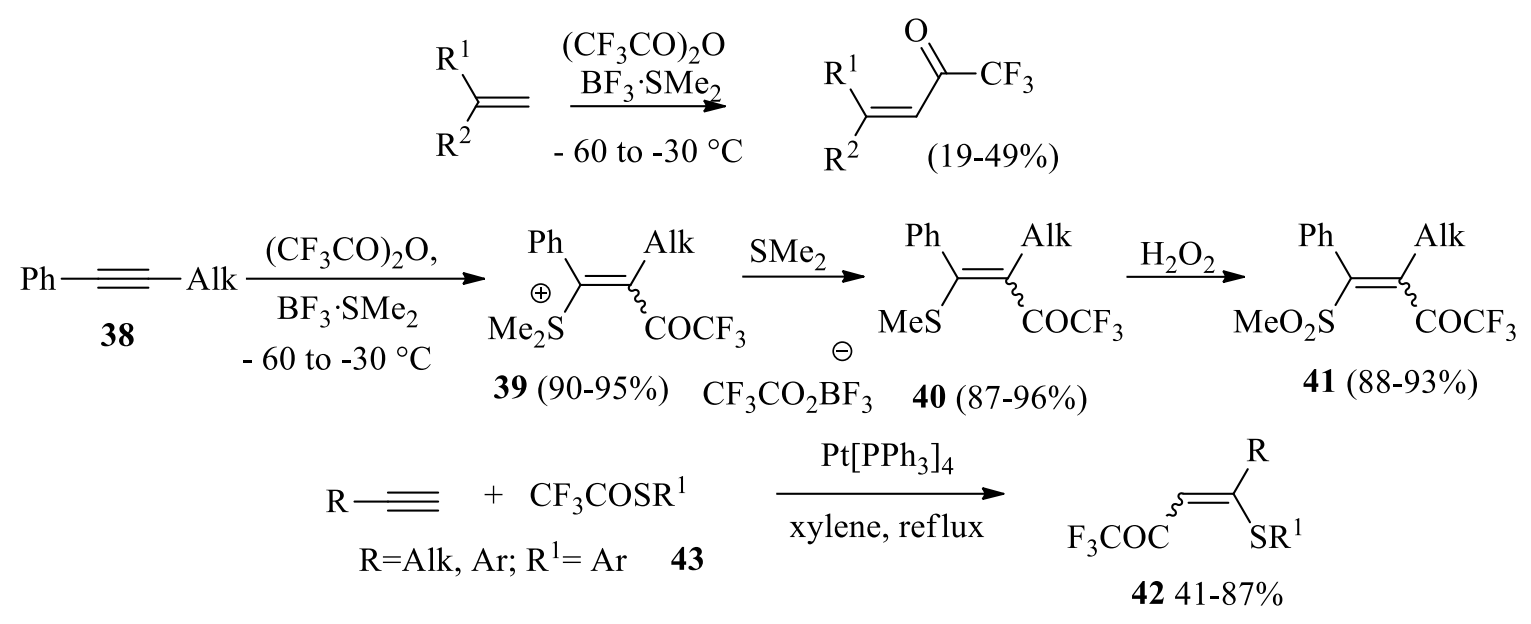

\section{Scheme 10}

2.1.2 Trifluoroacylation of organometallics. $\mathrm{CF}_{3}$-enones can be prepared by acylation of vinylic organometallic compounds. The first trifluoromethyl containing enone, 1,1,1-trifluoro-4-phenylbut-3-en-2-one 45, was synthesized in low yield by the reaction of styrylmagnesium bromide with trifluoroacetic acid in $1959 .^{25}$

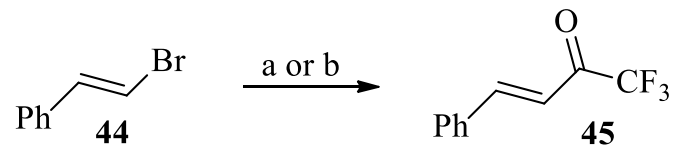

(a) $\mathrm{Mg}, \mathrm{Et}_{2} \mathrm{O} ; \mathrm{CF}_{3} \mathrm{COOH}(11 \%)$

(b) $\mathrm{Li}, \mathrm{Et}_{2} \mathrm{O} ; \quad \mathrm{F}_{3} \mathrm{COC}-\mathrm{N} \quad(63 \%)$

\section{Scheme 11}

Azaenolates 46 can be acylated by $\mathrm{N}$-substituted trifluoroacetimidoyl chlorides 47 to lead after hydrolysis $\beta$-enaminoketones $\mathbf{4 8} .^{26}$ Alternatively the trifluoroacylation of $\mathbf{4 9}$ with ethyl trifluoroacetates allows obtaining enaminoketones $\mathbf{5 0}$ directly in one stage. ${ }^{27}$

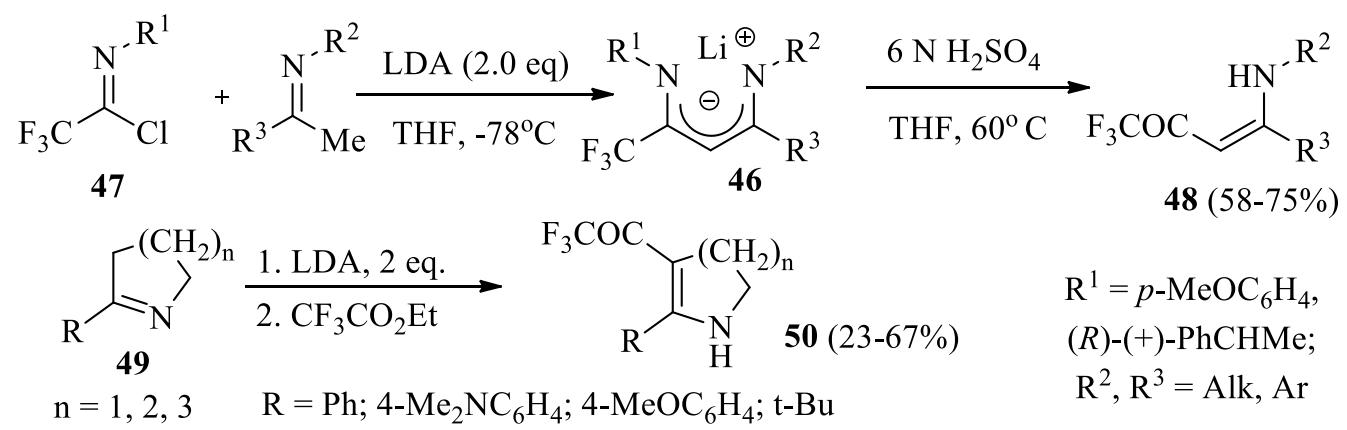

\section{Scheme 12}


Reaction of trifluoroacetimidoyl iodides $\mathbf{5 1}$ with various alkenes and alkynes in the presence of a palladium catalyst can be used for preparation of imino-derivatives of alkenyl $\mathbf{5 2}$ and alkynyl ketones 53. ${ }^{28}$ Similarly, phosphonates 56 were prepared via reaction of diethyl allylphosphonate $\mathbf{5 5}$ with 54. Subsequently compound 56 easily undergoes the migration of double bonds and after deprotonation, Wittig reaction and hydrolysis gave dienones $\mathbf{5 7} .^{29}$
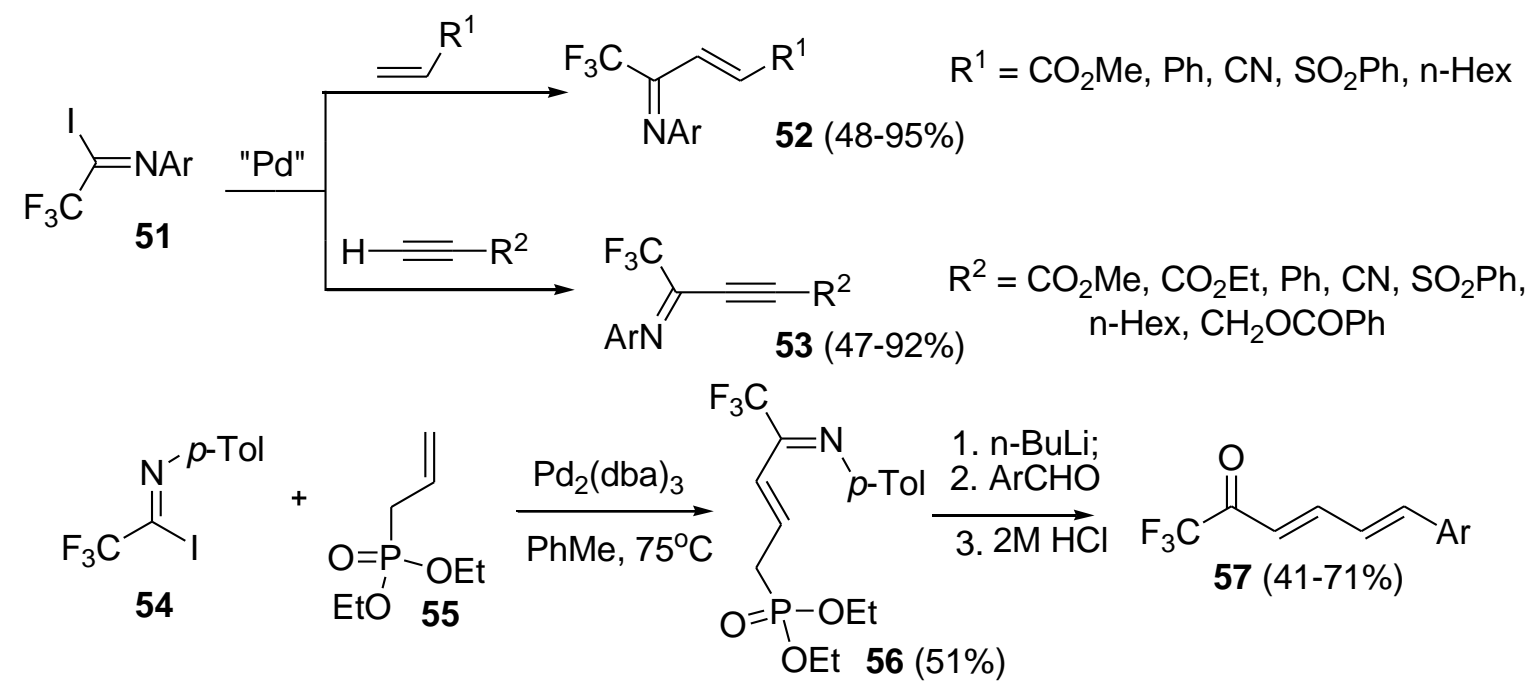

\section{Scheme 13}

Pd-catalyzed cross-coupling reaction of thioesters $\mathbf{5 8}$ with the corresponding alkenyl boronic acids $\mathbf{5 9}$ was used for the preparation of $\beta$-aryl- $\mathrm{CF}_{3}$-enones $\mathbf{6 0}{ }^{30}$

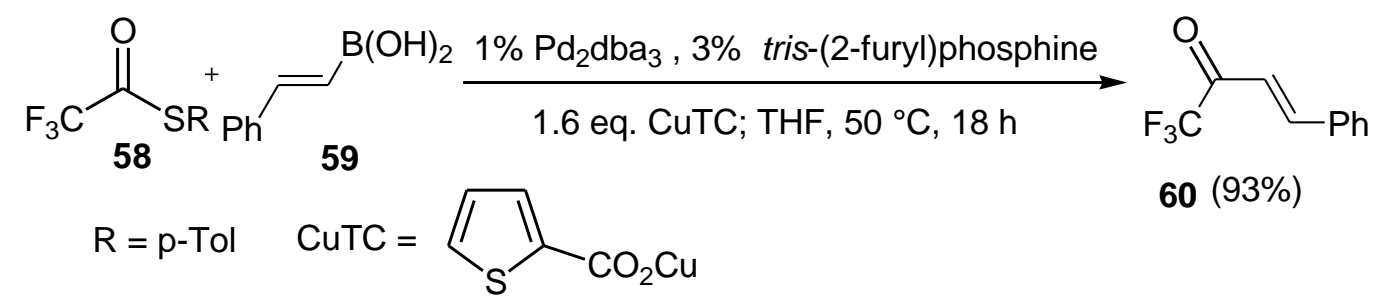

\section{Scheme 14}

2.1.3 Condensations and similar reactions. The condensation of 1,1,1-trifluoroacetone 61 with aromatic or $\alpha, \beta$-unsaturated aldehydes is catalyzed by the piperidine - acetic acid system in THF and makes it possible to prepare trifluoromethyl containing conjugated enones, dienones and polyenones (retinoids) 62. A drawback of this method is self-condensation of 1,1,1-trifluoroacetone. Therefore this reagent should be taken in more than 10 -fold excess. ${ }^{31}$ 


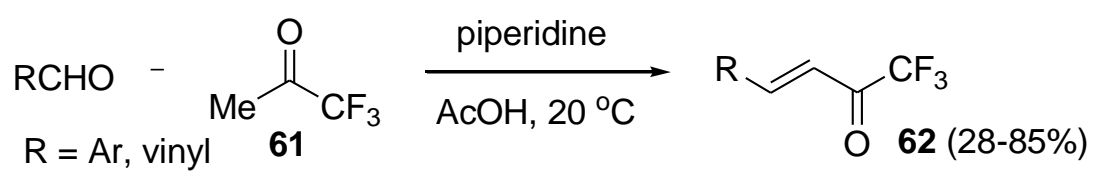

\section{Scheme 15}

$\alpha, \beta$-Unsaturated ketones are often prepared by condensation of $\beta$-dicarbonyl compounds with aldehydes and ketones. However, $\beta$-dicarbonyl compounds (for example 63) containing a perfluoroalkyl substituent yields a mixture of products in a relatively low yield. ${ }^{32}$

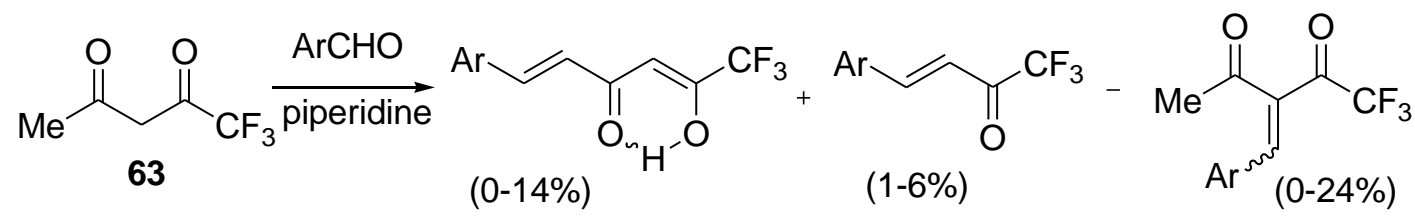

\section{Scheme 16}

Conjugated $\mathrm{CF}_{3}$-diene-dione $\mathbf{6 4}$ has been synthesized in high yield by reaction (catalyzed by $[\mathrm{Ru}] / \mathrm{CF}_{3} \mathrm{CO}_{2} \mathrm{H}$ ) of terminal propargylic alcohol 65 with hexafluoroacetylacetone 66 via MeyerSchuster rearrangement and subsequent aldol-type condensation. ${ }^{33}$

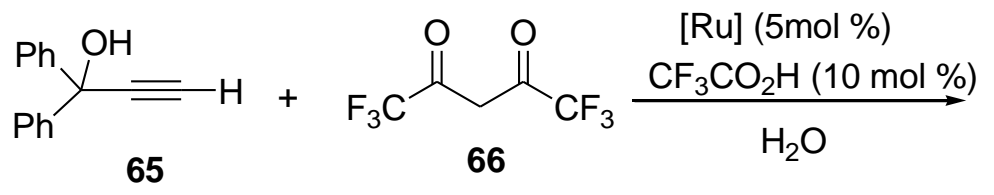<smiles>O=C(OC(F)(F)F)C(=CC=C(c1ccccc1)c1ccccc1)C(F)(F)F</smiles>

\section{Scheme 17}

The condensation of trifluoroacetoacetic acid esters 67 with aldehydes in the presence of traditional catalysts leads to $\mathrm{CF}_{3}$-enones $\mathbf{6 8}$ in moderate yields, better yields gave silica gel treated with (3-aminopropyl)triethoxysilane. ${ }^{34}$ Derivative 69 is formed by the reaction of 67 and triethylorthoformiate. Subsequent reaction with urea gives $\beta$-enamidoketone $69 \mathbf{a}^{35}$

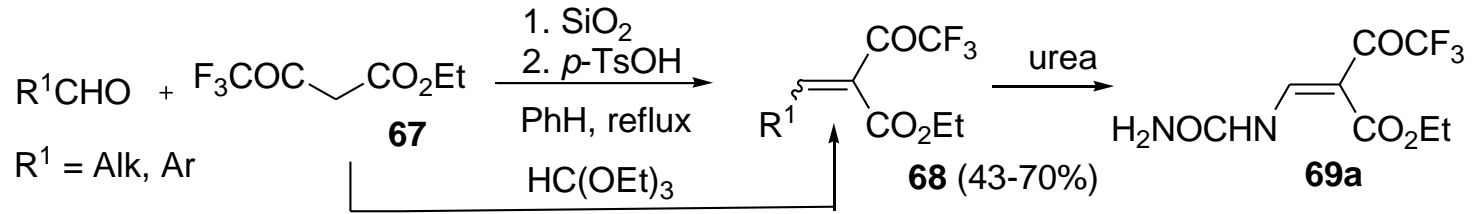

\section{Scheme 18}


The reaction of $\beta$-iminophosphonate anions with aldehydes (the Horner - Emmons reaction) yields perfluoroalkylated enones $\mathbf{7 2}$ as the final products.

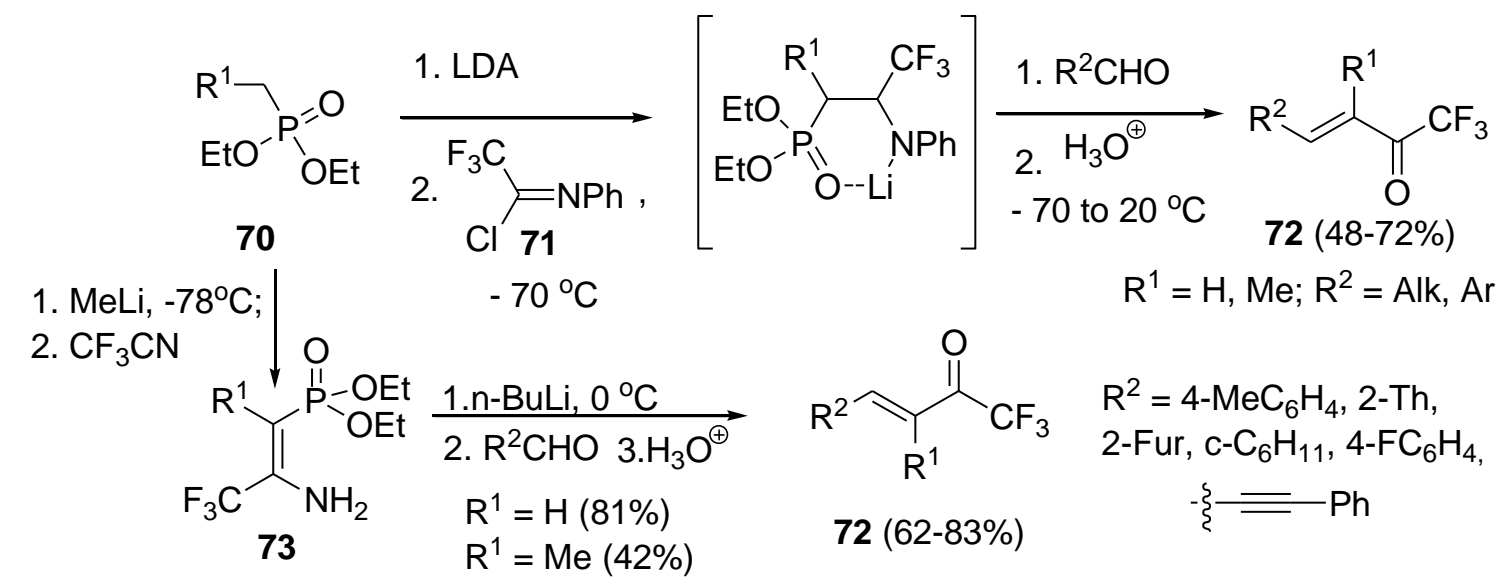

\section{Scheme 19}

$\beta$-Iminophosphonate anions can be obtained from diethyl alkylphosphonates $\mathbf{7 0}$ and trifluoroacetimidoyl chlorides $\mathbf{7 1}$ as a one-pot procedure. Subsequent reaction with aldehydes leads to $\mathbf{7 2}$ in good yields. Enaminophosphonates $\mathbf{7 3}$ can be prepared by condensation of phosphonates $\mathbf{7 0}$ with trifluoroacetonitrile. ${ }^{36}$

Sulfanyl substituted ethyl (1,1,1-trifluoromethyl)vinyl ethers $\mathbf{7 4}$ can be easily lithiated with $n$ BuLi. Structurally similar selenium compounds 77 can be converted to lithium derivatives by lithiation to vinyl position or by Se-Li exchange. In both cases the reactions with various aldehydes form allylic alcohols $\mathbf{7 8}$ or $\mathbf{8 0}$ correspondingly. Subsequent acidic treatment leads to trifluoromethylketones $\mathbf{7 9}$ or $\mathbf{8 1} .^{37}$

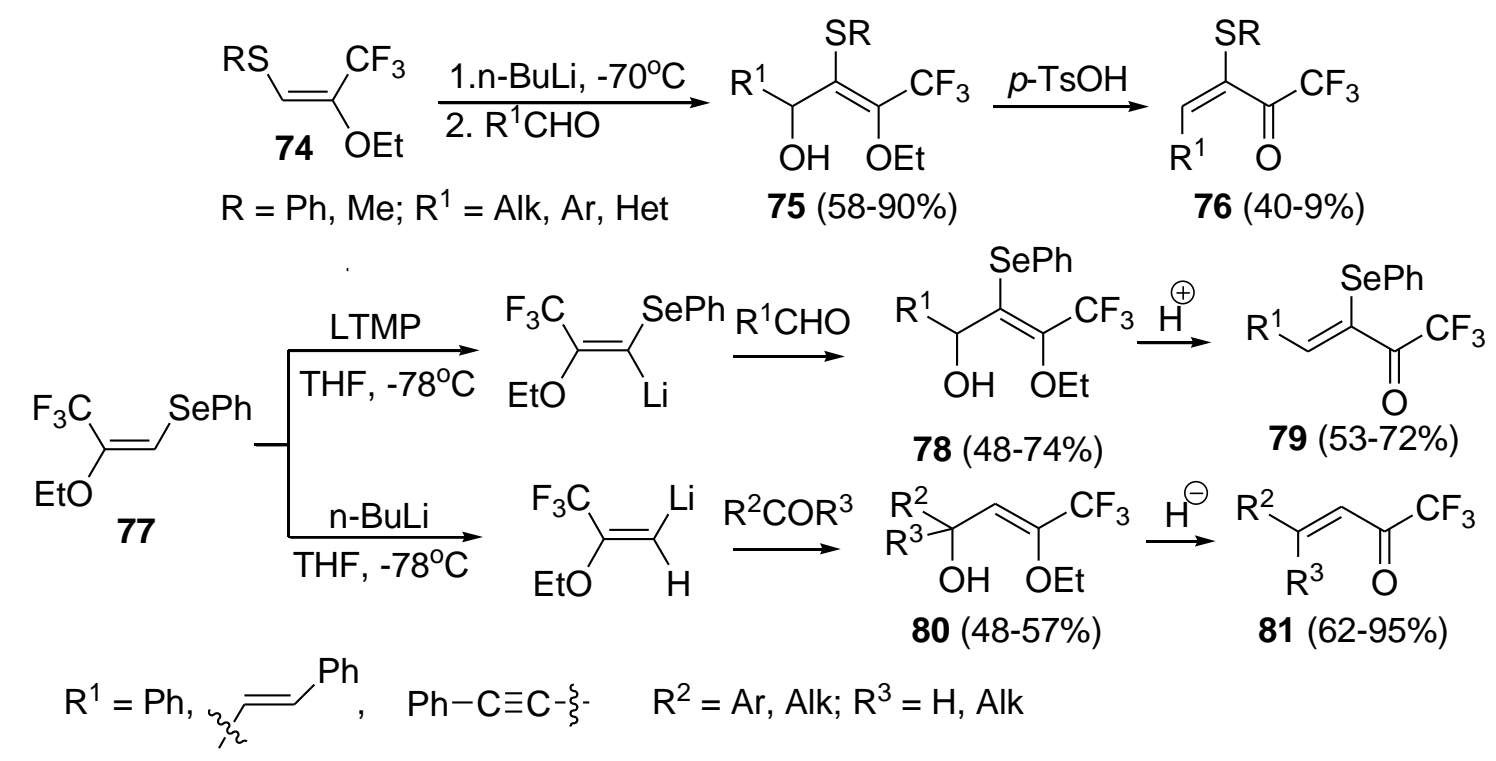

\section{Scheme 20}


Claisen rearrangement has been also used for synthesis of $\mathrm{CF}_{3}$-dienones. 1-Phenylsulfanyl-2bromo-3,3,3-trifluoropropene $\mathbf{8 2}$ served as starting material.

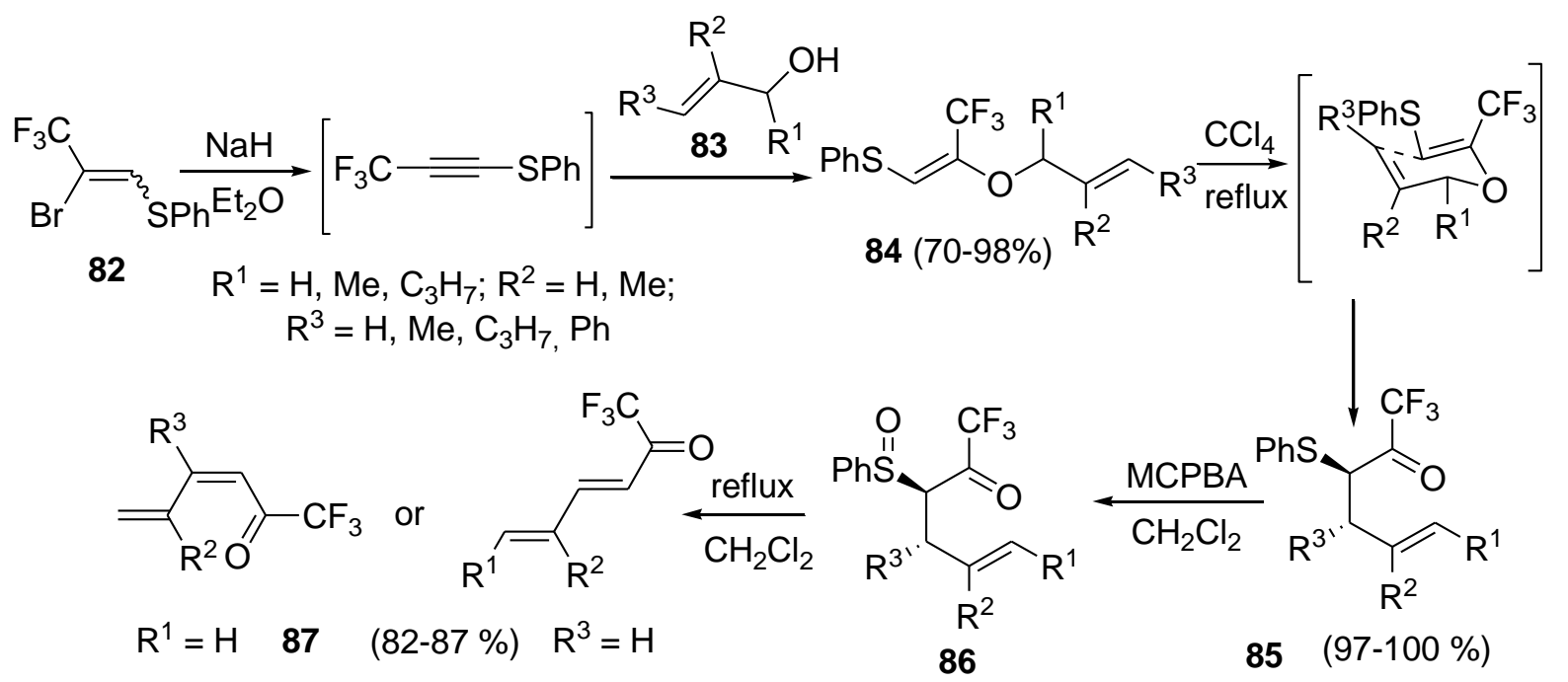

\section{Scheme 21}

The reaction of $\mathbf{8 2}$ with sodium hydride leads to $\mathrm{CF}_{3}$-acetylene which reacted with various allylic alcohols $\mathbf{8 3}$ to form vinyl ethers $\mathbf{8 4}$. Subsequent heating generate $\gamma, \delta$-unsaturated ketones $\mathbf{8 5}$. Target dienone $\mathbf{8 7}$ was formed by oxidation of phenylsulfanyl group in $\mathbf{8 5}$ with $m$-chloroperbenzoic acid and syn-elimination of sulfenic acid from sulfoxide $\mathbf{8 6} .^{38}$

Claisen reaction was also studied for vinyl propargyl ethers. $\mathbf{8 8}$ reacted with propargylic alcohols 89 to form vinyl ether $\mathbf{9 0}$. Claisen rearrangement with further double-bond migration takes place under heating in toluene at $80^{\circ} \mathrm{C}$ leading to 91 as a mixture of $Z / E$ isomers. ${ }^{39}$

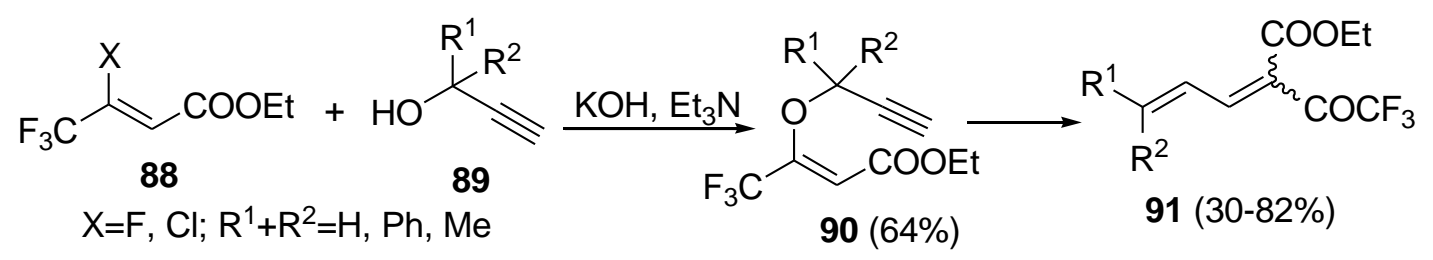

\section{Scheme 22}

2.1.4 Nucleophilic substitution at the $\beta$-position. $\alpha, \beta$-Unsaturated trifluoromethylketones having heteroatom in $\beta$-position (e.g. alkoxy-, dialkylamino-substituted) can be involved into the reactions with nucleophiles by "addition-elimination" mechanism with further formation of new $\alpha, \beta$ unsaturated trifluoromethyl ketones. Trifluoromethyl enaminones 94 can be synthesized by the reaction of 1,3-dicarbonyl compounds 92 containing trifluoroacetyl fragment with primary and secondary amines and diamines. ${ }^{40}$ Lewis acids (ether $-\mathrm{BF}_{3}$ complex and $\mathrm{Zn}\left(\mathrm{ClO}_{4}\right)_{2}$ ) accelerate the reaction. $^{41}$ 


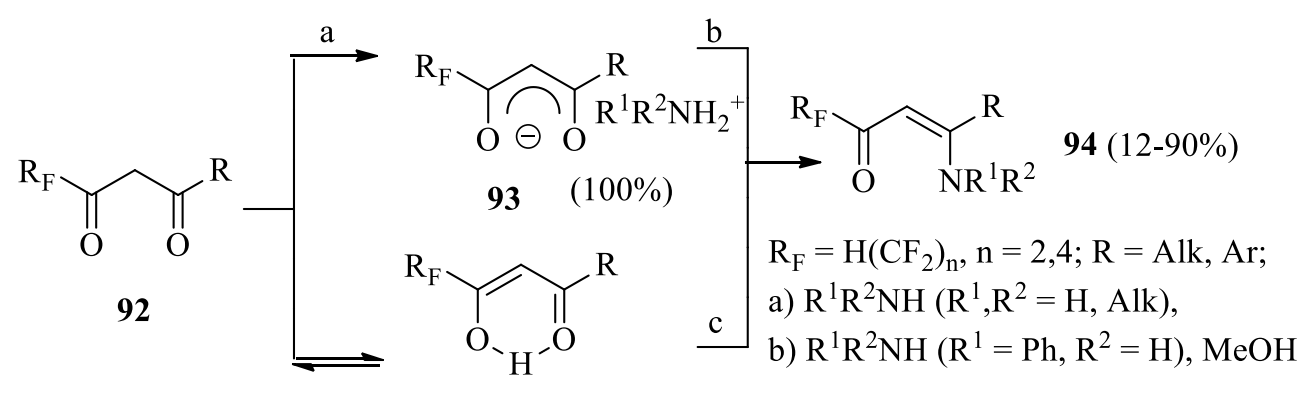

\section{Scheme 23}

Enaminones 95 can be obtained by the reaction of ammonia or amines with $\beta$-chlorovinyl ketones 97 prepared by reaction of polyfluorinated $\beta$-diketones with $\mathrm{SOCl}_{2}$ in the presence of $\mathrm{DMF}$ as a catalyst or with the Vilsmeier reagents $\left(\mathrm{DMF} / \mathrm{POCl}_{3}\right.$ or $\left.\mathrm{DMF} /(\mathrm{COCl})_{2}\right)$. This approach has also been used to synthesize hexafluoromono-thioacetylacetone $\mathbf{9 8}$ existing in enol form. ${ }^{42}$

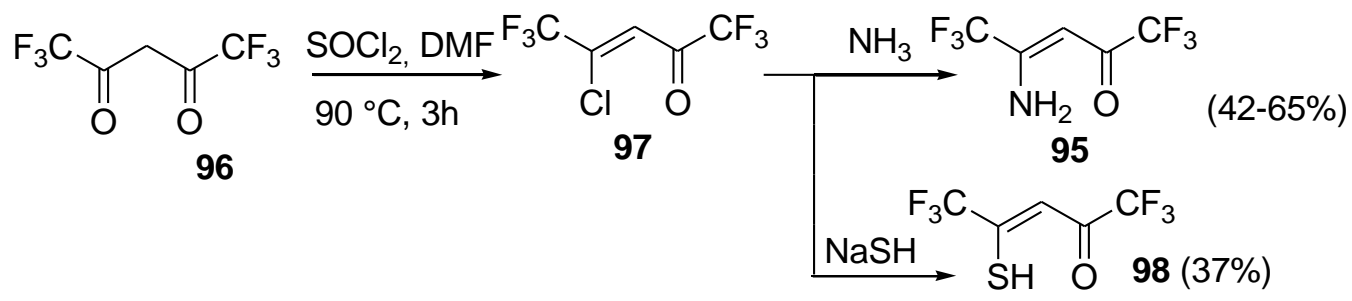

\section{Scheme 24}

The alkoxy enones 99 react easily with various amines. They can be used as selective protecting groups for $\alpha$-amino group of $\alpha$-aminoacids $\mathbf{1 0 0}$ to form 101. The cleavage of this protective group is performed by treatment with hydrogen chloride in methanol. ${ }^{43}$

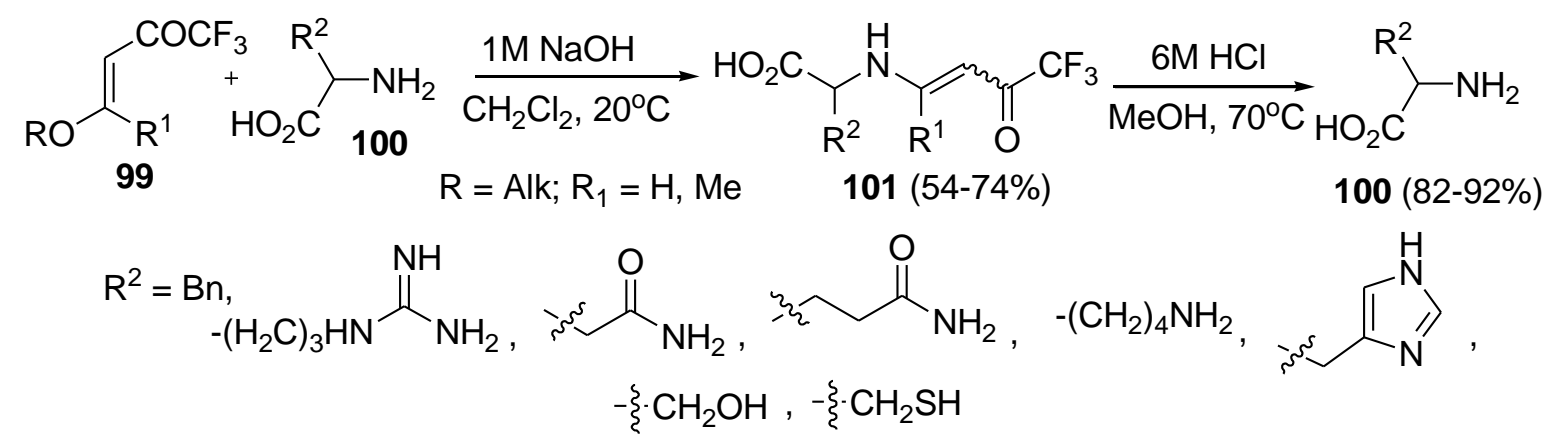

\section{Scheme 25}

5-Trifluoroacetyl-3,4-dihydro-2H-pyran 102 reacts with many nucleophiles such as amines and Grignard reagents to give the ring opening products $\mathbf{1 0 3}$. Hydrazine and hydroxylamine attack the carbonyl carbon of the title compound to form hydrazone or oxime $104 .{ }^{44}$ 


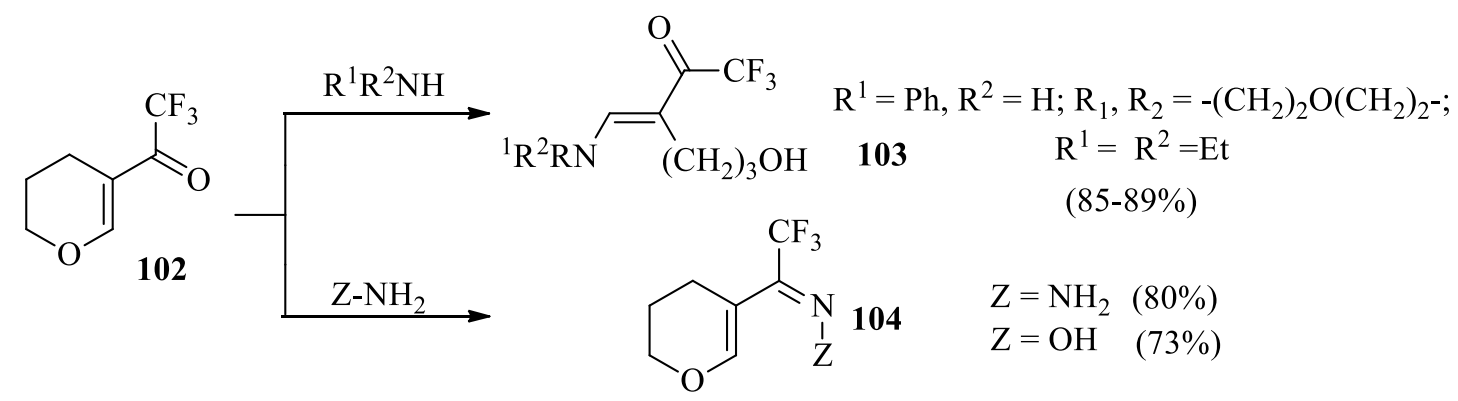

\section{Scheme 26}

Ketones 105 containing aziridine fragment in $\beta$-position were prepared by reaction of cis-1,2diphenylaziridine 106 with $\mathrm{CF}_{3}$-enone 107 containing chlorine atom in the $\beta$-position. Reaction proceeds with the formation of mixture of $E$-Z-isomers of ketone $\mathbf{1 0 5} .^{45}$
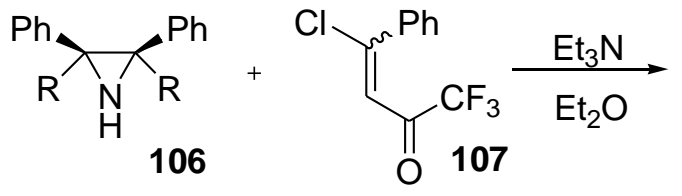

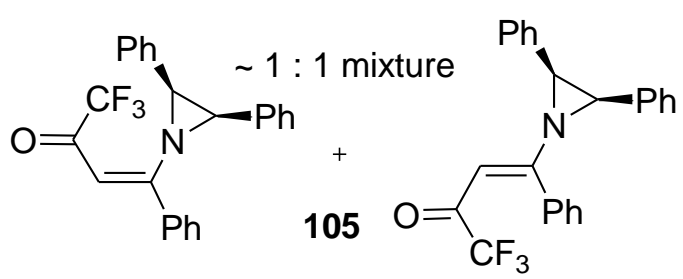

$$
R=H,(77 \%) R=M e,(15 \%)
$$

\section{Scheme 27}

The enone 108 reacts with the phenylmagnesium bromide to give a mixture of $\beta$ trifluoroacetylstyrene 109 and allylic alcohol 110 in overall yield of 40-60\%. The reaction of phenylmagnesium bromide with 4-diethylamino-1,1,1-trifluorobut-3-en-2-one 111 occurs more unambiguously. It gives only $\beta$-trifluoroacetylstyrene 109 in moderate yield. ${ }^{46}$

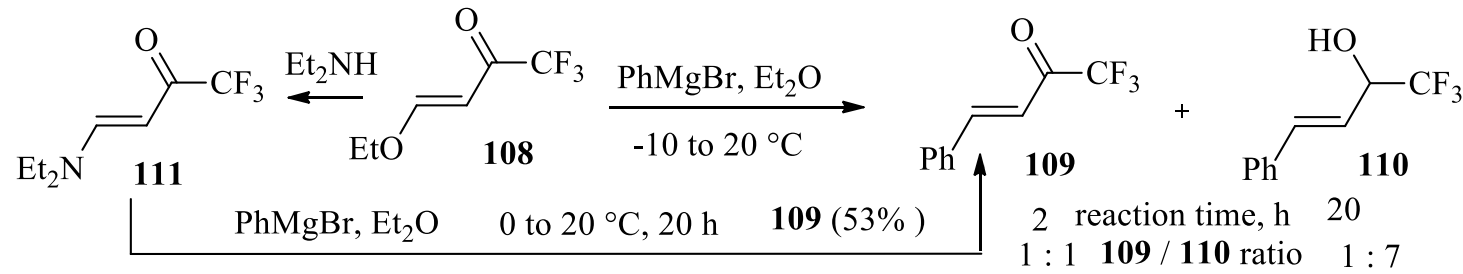

\section{Scheme 28}

The reactions of various Grignard and organolithium reagents with enones 112a,b proceed stereoselectively leading to the formation of $\mathrm{CF}_{3}$-enones 113a. Using the reaction of lithiated ferrocene allows preparing the corresponding $\mathrm{CF}_{3}$-enones 114-116. ${ }^{47}$ Additionally enones 112a were used for the preparation of conjugated trifluoromethylenones $113 \mathbf{b}$ containing acetylenic fragment by the reaction with lithiated acetylenes. ${ }^{48}$ 

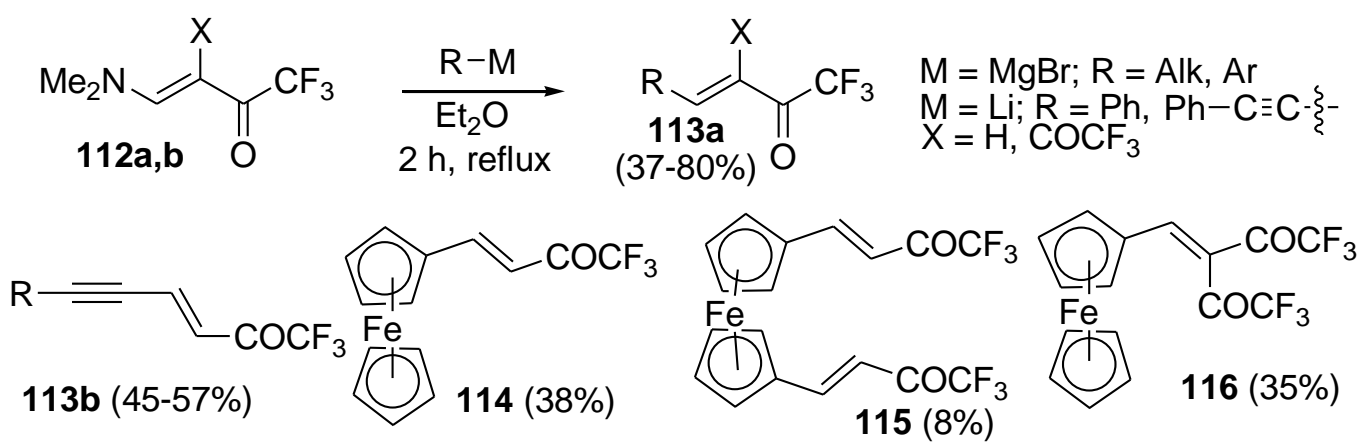

\section{Scheme 29}

The similar reaction of organolithium derivatives with cyclic enaminoketones 117 was applied to the synthesis of cyclobutene ketones 118. The formation of corresponding hydroxyketones 119 as byproducts was observed. ${ }^{49}$

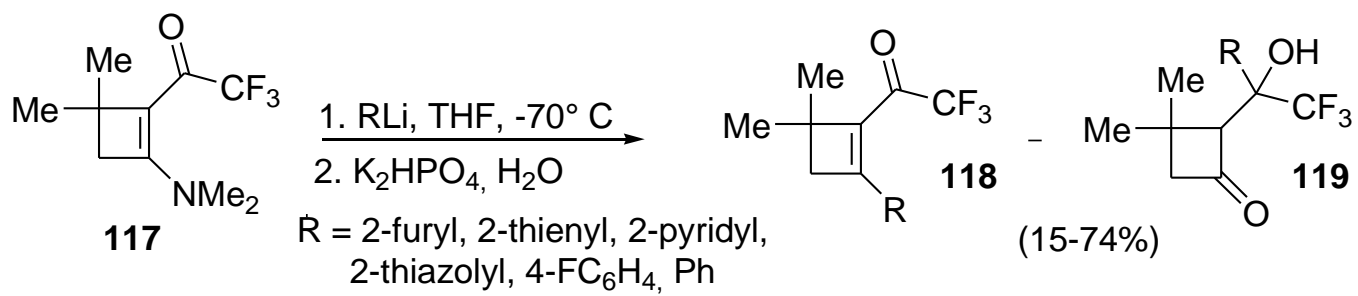

\section{Scheme 30}

The cross-coupling reaction for the synthesis of bicyclic cyclobutene ketones $\mathbf{1 2 0}$ containing substituents in $\beta$-position was applied. The reaction of arylzinc-derivatives with the corresponding bromide 121 in the presence of $\left(\mathrm{Ph}_{3} \mathrm{P}\right)_{4} \mathrm{Pd}$ catalyst was used. ${ }^{50}$

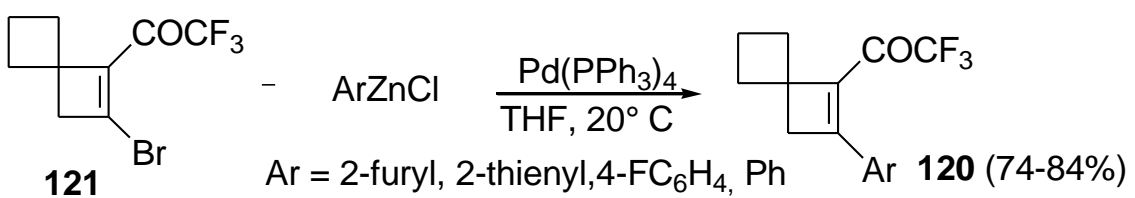

\section{Scheme 31}

Trifluoromethyl enones 122 can also be synthesized using the reaction of various zinc dialkyland diaryl-cuprates with 123. In the case of zinc dialkylcuprates, the reaction is accompanied by side formation of the double addition products $124 .{ }^{51}$ 


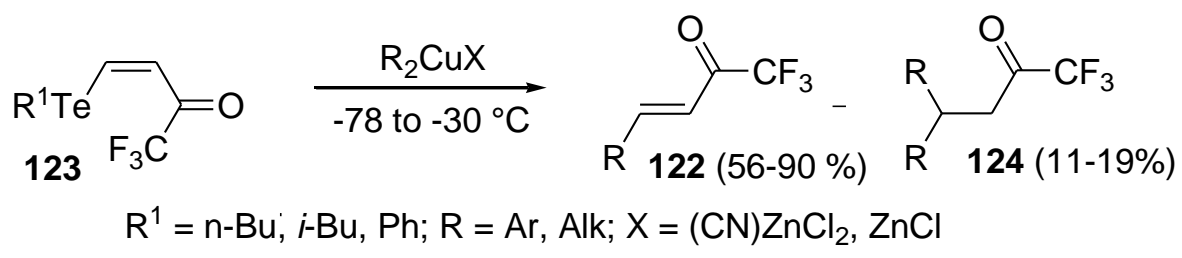

\section{Scheme 32}

The reactions of trifluoroacetylated vinyl ethers 125 with organoboron compounds 126 allows to prepare highly stereoselectively the corresponding dienones $\mathbf{1 2 7}$ and enynones $\mathbf{1 2 8}{ }^{52}$

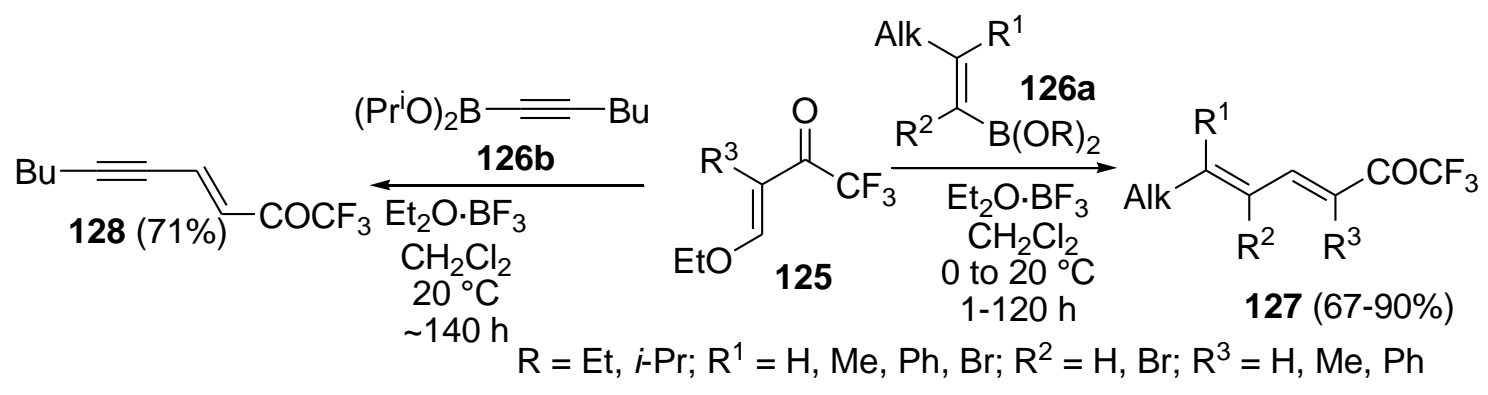

\section{Scheme 33}

$\beta$-Alkoxy substituted trifluoromethyl enones $\mathbf{1 2 9}$ are used as the starting compounds in a large number of syntheses, such as the reactions with diverse nucleophiles - electron rich aromatic compounds. This reaction in the presence of zinc chloride can be carried out only for reactive aromatic compounds such as indoles, pyrroles and $\mathrm{N}, \mathrm{N}$-dimethylaniline. Other heterocyclic compounds such as furan, 2-methylfuran and thiophene do not reacted. Also this reaction was used for preparation of $\beta$-uracil substituted $\mathrm{CF}_{3}$-enone 131. ${ }^{46,53}$

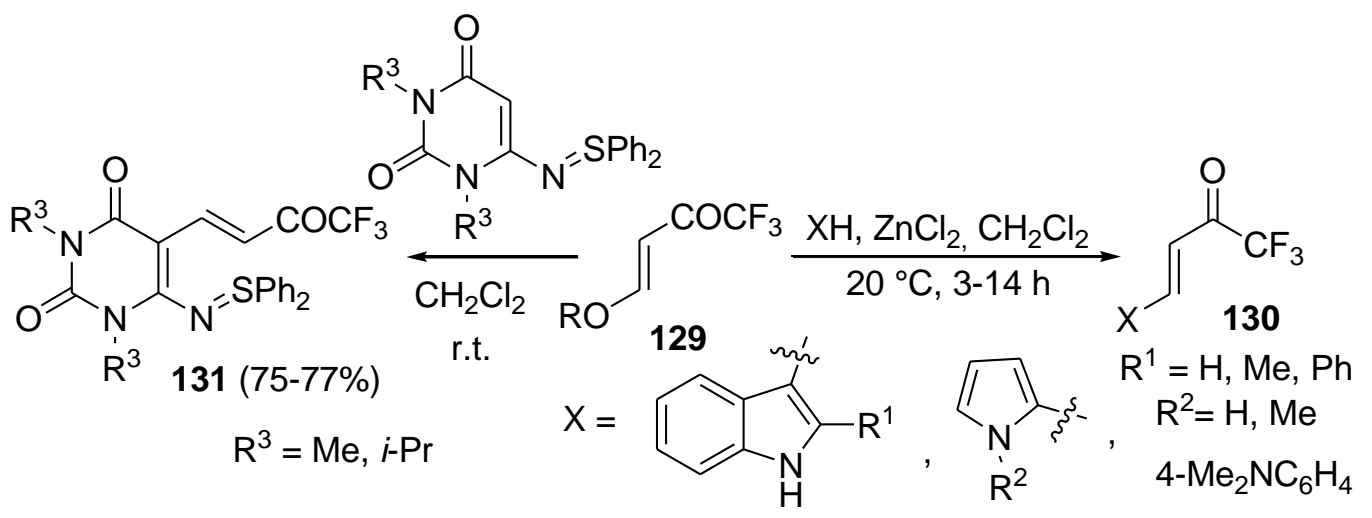

\section{Scheme 34}


A number of works is devoted to application of 4-sulfonyl-1,1,1-trifluorobut-3-en-2,2-diols 132 for synthesis of various $\beta$-amino and $\beta$-thio- $\alpha, \beta$-unsaturated trifluoromethylketones. Compounds 132 can be prepared by oxidation of $\beta$-thiosubstituted enones 133 using $50 \% \mathrm{H}_{2} \mathrm{O}_{2}$ in the presence of trifluoroacetic acid or utilizing $98 \% \mathrm{H}_{2} \mathrm{O}_{2}$ solution in the presence of trifluoroacetic acid anhydride. Similarly sulfoxide $\mathbf{1 3 4}$ can be prepared. ${ }^{54}$

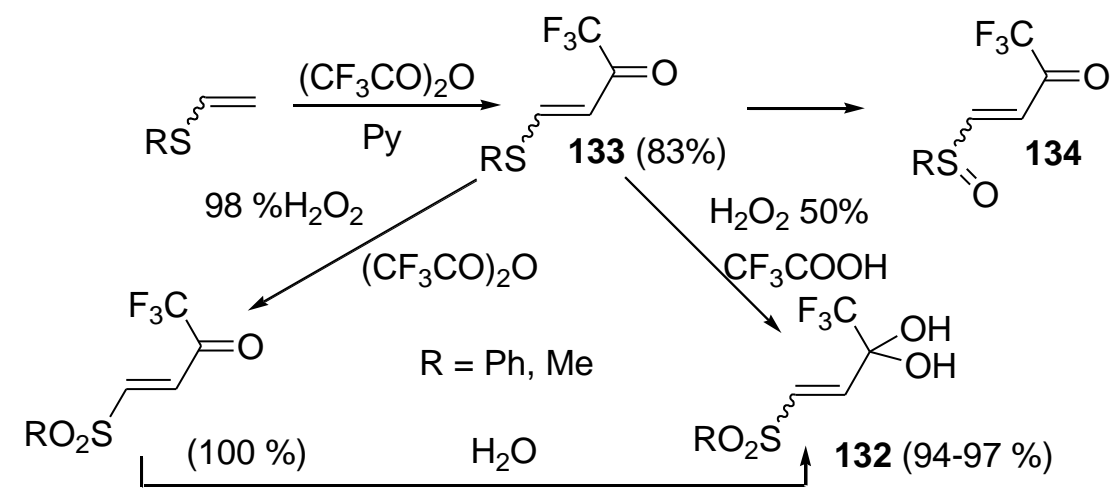

\section{Scheme 35}

The reaction of $\mathbf{1 3 2}$ with various amines leads to the corresponding enaminoketones $\mathbf{1 3 5}$ in high yields. The reaction of $\mathbf{1 3 2}$ with various thiols shows the new pathway to $\beta$-sulfanylenones $\mathbf{1 3 6}{ }^{55}$ Compounds 132 are very reactive electrophiles and were used for the preparation of $\mathrm{CF}_{3}$-enones 137 containing heterocyclic substituent in $\beta$-position by the reaction with furans, indoles, pyrroles, triazole, imidazole, pyrazole and their benzo-derivatives. ${ }^{56}$

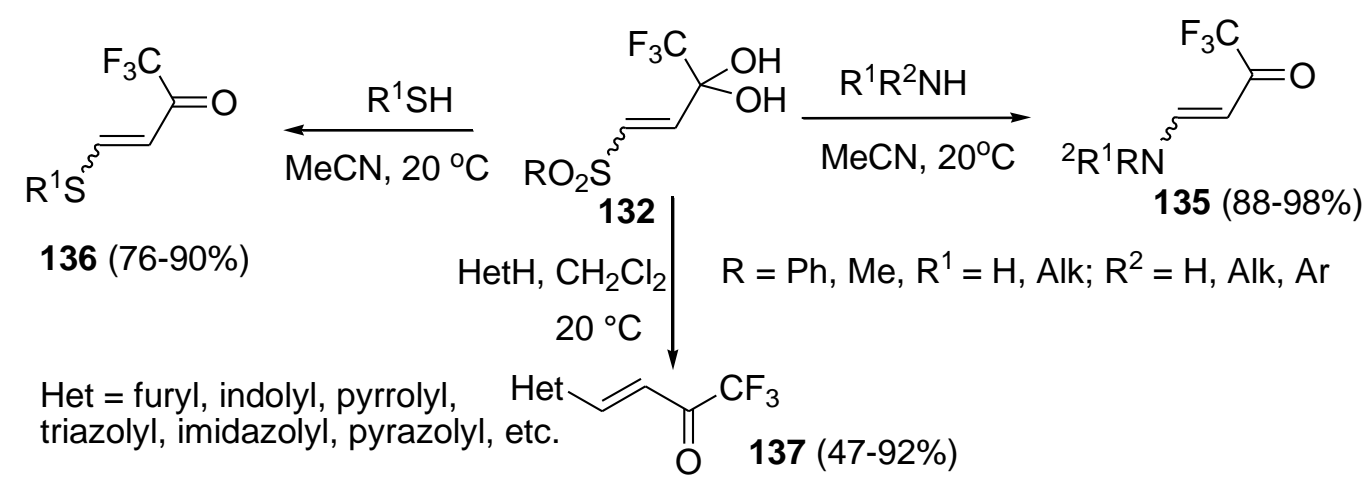

\section{Scheme 36}

New highly electrophilic reagent 138 obtained by oxidation of 139 was applied for the synthesis of $\alpha$-phenylsulfonyl enones 140, 141 by reaction with aromatics and heteroaromatics. ${ }^{57}$ 


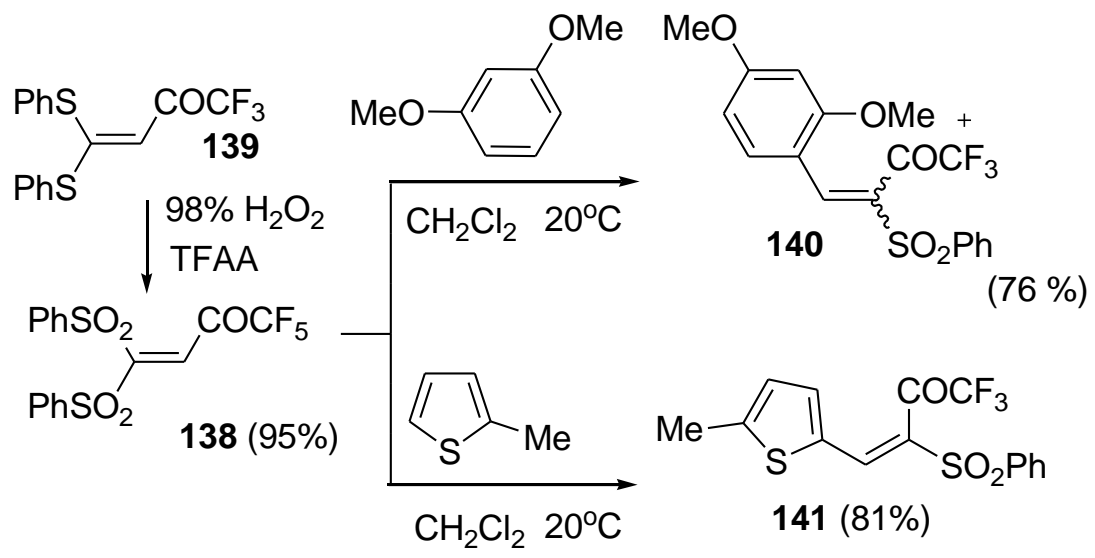

\section{Scheme 37}

Enones 142 containing OTs group in $\alpha$-position to carbonyl group are formed under treatment of allylic alcohols 143 with sulfuric acid. Compounds 143 were prepared from lithium derivative 144 and carbonyl compounds. Intermediate lithium derivative 144 can be synthesized from fluoroalkene 145 and also by direct metallation of 146 with 2 equivalents of $n$-BuLi. ${ }^{58}$

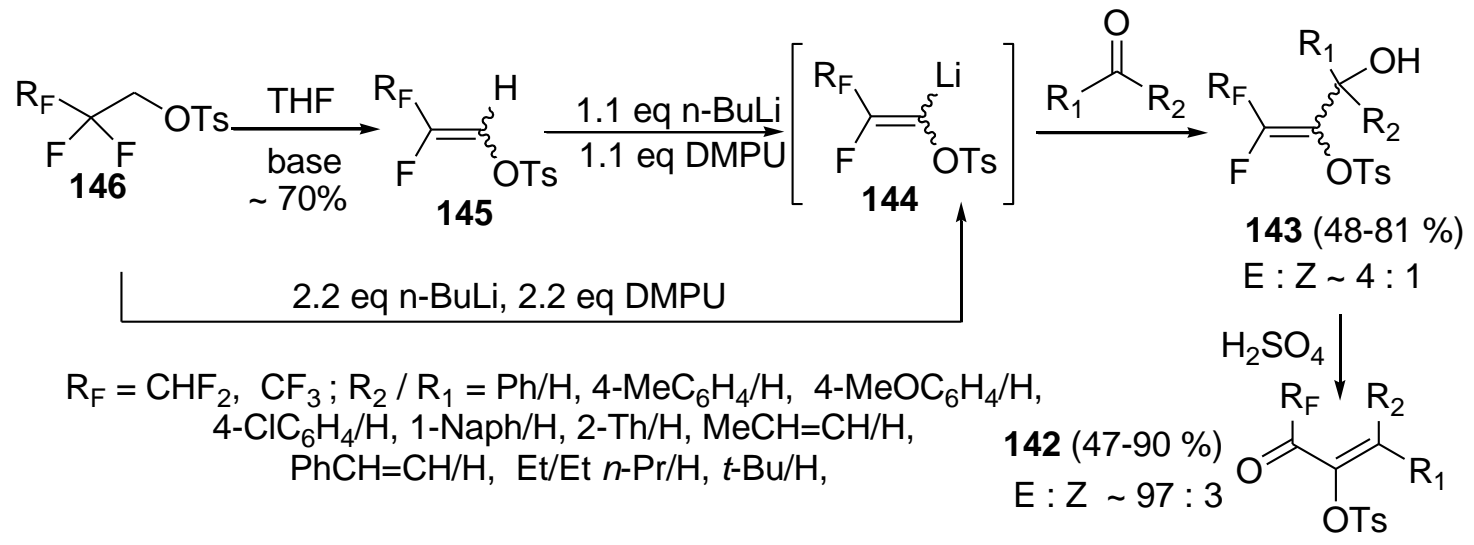

\section{Scheme 38}

Polyfluorinated aldehydes 147 were used for synthesis of $\beta$-enaminoketones 148. Target $\mathrm{N}$ substituted $\beta$-enaminoketones $\mathbf{1 4 8}$ are formed in good yields by reflux of acetonitrile solution of polyfluorinated aldehydes with various amines in the presence of water. ${ }^{59}$

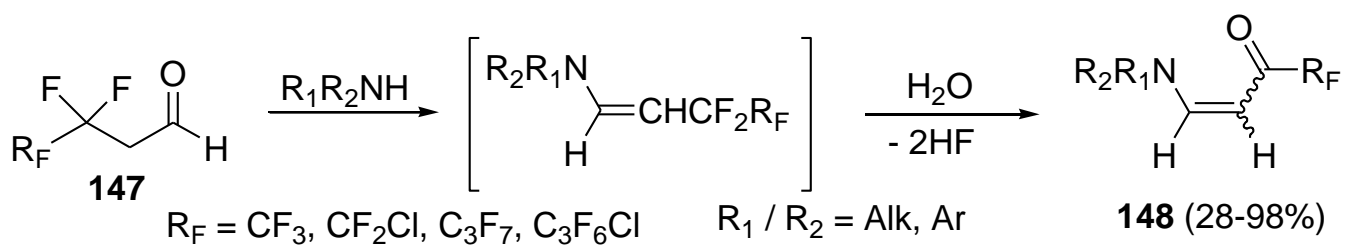

\section{Scheme 39}


$\beta$-(Thio)alkoxy-substituted trifluoromethyl enones 149 and 150 react with ammonia and primary and secondary amines (including aromatic ones) to give $\beta$-amino-substituted enones (enaminones) 151 in high yields. ${ }^{60}$

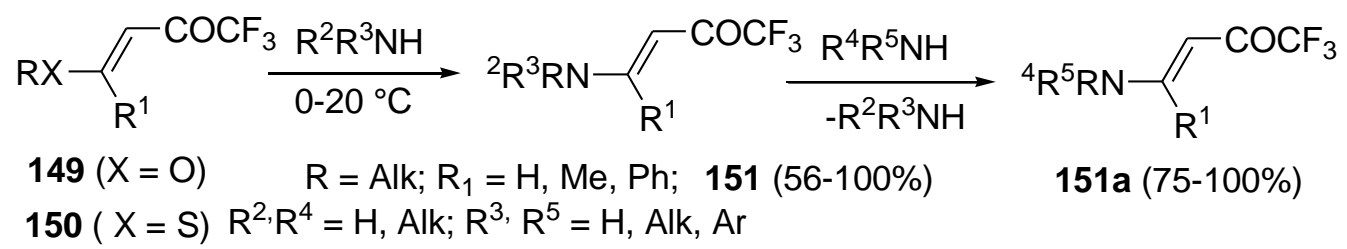

\section{Scheme 40}

The substitution of one alkoxy-group in enone 152 was used for synthesis of O,N-acetalsaminals of trifluoroacetylketene $\mathbf{1 5 3}$ in aqueous medium. ${ }^{61}$

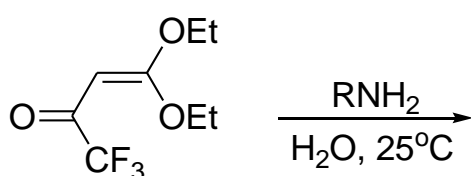

152<smiles>CCO/C(=C/C(=O)C(F)(F)F)NP</smiles>

$153(60-89 \%)$

\section{Scheme 41}

The example of synthesis of $\beta$-selenoenones 154 using the reaction of methoxyenones 155 with methyl- and phenylselenol in the presence of $\mathrm{BF}_{3}$-diethyl etherate was described. ${ }^{62}$

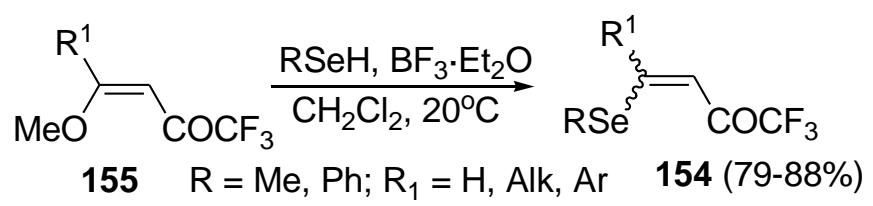

\section{Scheme 42}

The introduction of cyano-group in the $\beta$-position of $\alpha, \beta$-unsaturated trifluoromethyl ketones can essentially broaden their synthetic potential as building blocks. Depending on the solvent and catalyst applied individual products 156 and 157 or their mixture can be obtained. $\beta$-Cyanoenone $\mathbf{1 5 8}$ was also prepared by treatment of $\mathbf{1 5 6}$ with concentrated sulfuric acid. ${ }^{63}$ 


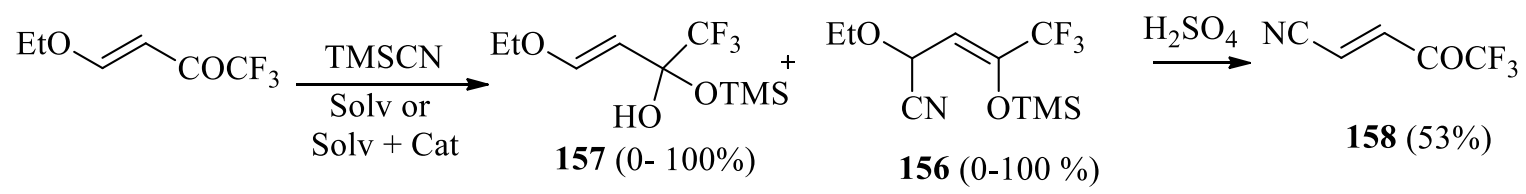

$\mathrm{Cat}=\mathrm{Et}_{3} \mathrm{~N}, \mathrm{i}-\mathrm{Pr}_{2} \mathrm{NEt}$, DMAP, N-methylephedrine, $\mathrm{LiBr}$,

$\mathrm{TiCl}_{4}, \mathrm{Et}_{2} \mathrm{O} \cdot \mathrm{BF}_{3},(\mathrm{i}-\mathrm{PrO})_{4} \mathrm{Ti}_{1} \mathrm{CF}_{3} \mathrm{SO}_{3} \mathrm{TMS}, \mathrm{I}_{2}, \mathrm{ZnI}_{2}, \mathrm{LiClO}_{4}, \mathrm{Hg}\left(\mathrm{CF}_{3} \mathrm{COO}\right)_{2}$

\section{Scheme 43}

2.1.5 Modification of the $\alpha$-position. The addition of halogen to the double bond of enones followed by dehydrohalogenation of intermediate dihaloketone 159 allows preparation of $\alpha$ chloro(bromo)- $\alpha, \beta$-unsaturated trifluoromethyl ketones $\mathbf{1 6 0}$. The iodoenone was prepared using ICl in $75 \%$ yield. ${ }^{64}$
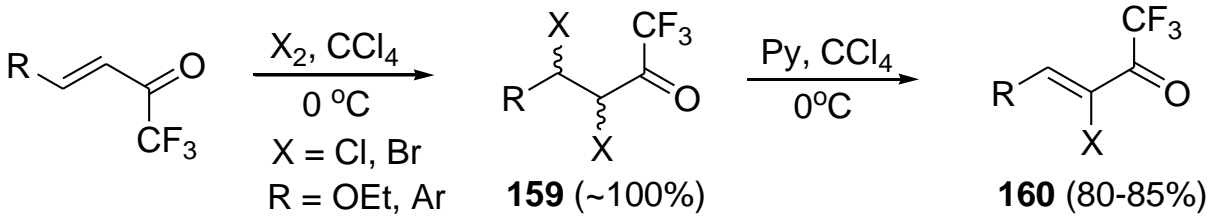

\section{Scheme 44}

The reaction of $\mathrm{CF}_{3}$-enaminoketones $\mathbf{1 6 1}$ with tosylisocyanate leads to mixture of the adducts 162 and 163 depending on the substituent in the enaminoketone. ${ }^{65}$

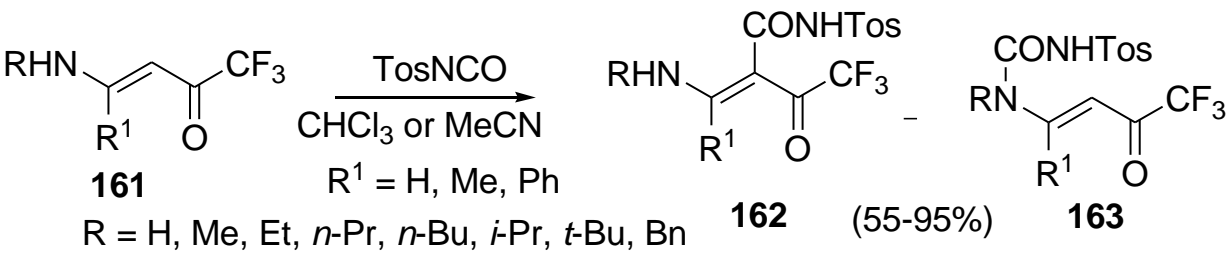

\section{Scheme 45}

The acylation reaction of secondary $\mathrm{CF}_{3}-\beta$-enamino ketones with TFAA or ethoxyoxalyl chloride led regioselectively to $\mathrm{N}$-acylated enaminones $\mathbf{1 6 4}$ in good yields. On the other hand, when tertiary enaminones were used, the acylation reaction led to $\mathrm{C}$-acylated enaminones $\mathbf{1 6 5} .{ }^{66}$

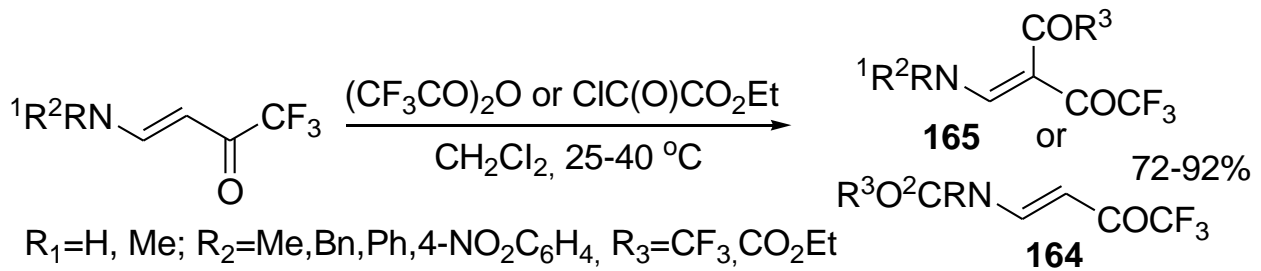

\section{Scheme 46}


2.1.6 Other methods. The standard way for preparation of $\alpha, \beta$-unsaturated ketones from aliphatic ketones is the treatment with phenylselenyl chloride followed by oxidation and elimination of $\mathrm{PhSeOH}$. This method was used for preparation of cyclic $\mathrm{CF}_{3}$-enone 166 from 1,3-diketone $167 .{ }^{67}$

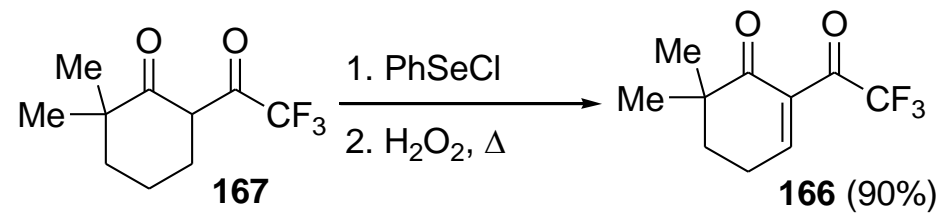

\section{Scheme 47}

Trifluoromethyl-containing allylic alcohols 168 can be oxidized into the corresponding enones 169 on treatment with the Dess-Martin reagent or Swern reagent (DMSO oxalylchloride/triethylamine). Manganese dioxide in $\mathrm{CH}_{2} \mathrm{Cl}_{2}$ was also used for this purpose. Nowadays this method has become customary because of development of synthetic approach to allylic alcohols using Ruppert reagent $\left(\mathrm{TMS}-\mathrm{CF}_{3}\right){ }^{68}$

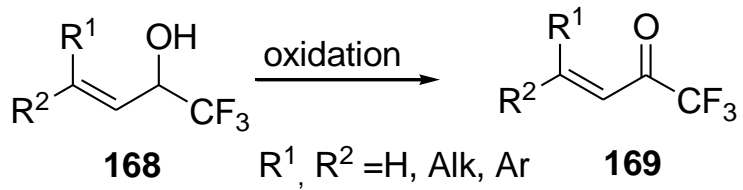

\section{Scheme 48}

The corresponding acrylic esters can be converted into $\alpha, \beta$-unsaturated trifluoromethyl ketones 171 by addition of Ruppert reagent $\left(\mathrm{TMS}-\mathrm{CF}_{3}\right)$ using cesium fluoride as the catalyst. The intermediate acetals $\mathbf{1 7 0}$ can be hydrolyzed by acid. ${ }^{69}$ The reactions of the acyl chlorides with trifluoromethylsilver generated in situ proceed selectively in EtCN giving the corresponding trifluoromethylketones $\mathbf{1 7 1}$ in moderate yields. ${ }^{70}$

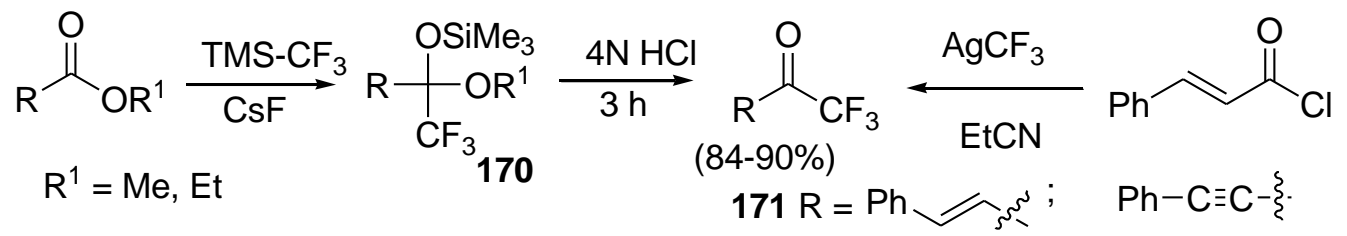

\section{Scheme 49}

\subsection{Synthesis of acetylenic $\mathrm{CF}_{3}$-ketones}

The set of methods for preparation of acetylenic $\mathrm{CF}_{3}$-ketones is much narrow than the set for preparation of $\mathrm{CF}_{3}$-enones. There are only several universal methods for preparation of acetylenic 
$\mathrm{CF}_{3}$-ketones. The classical method is the trifluoroacylation of anions $\mathbf{1 7 2}$ generated from terminal alkynes with TFAA, ethyl or trifluoroethyl trifluoroacetate to form $\mathbf{1 7 3} .^{71}$

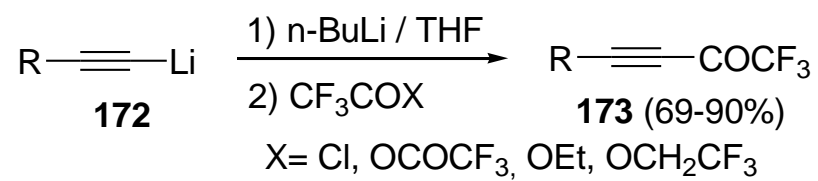

\section{Scheme 50}

Another convenient method is the sequence for the preparation of secondary propargylic alcohols 174 starting with acetylenes and fluoral with further oxidation into ketones $175 .{ }^{72} \mathrm{The}^{\mathrm{CF}_{3}-}$ containing alkynone 176 was synthesized by reaction of aldehyde 177 with $\mathrm{TMSCF}_{3}$ followed by oxidation of alcohol 178 with Dess-Martin periodinane. ${ }^{73}$

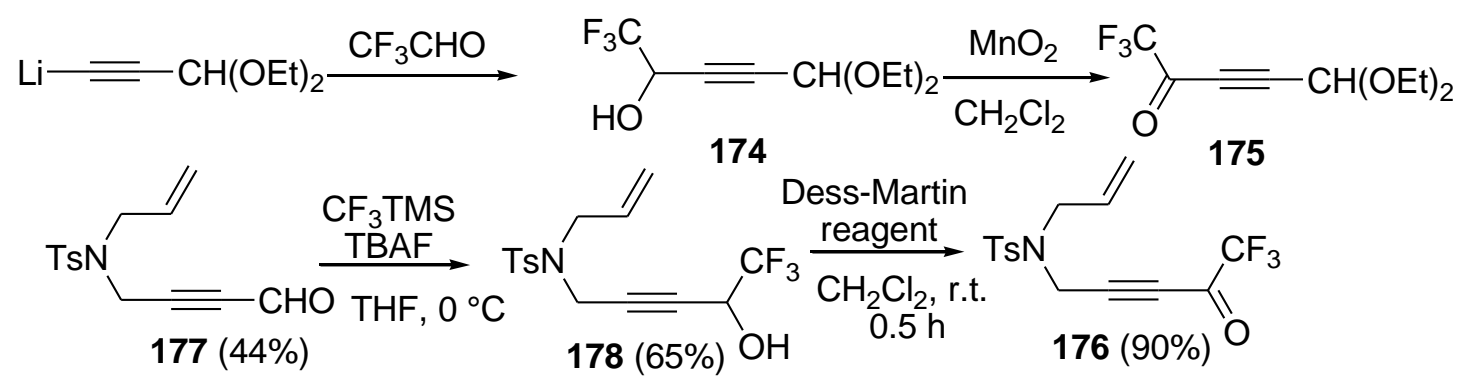

\section{Scheme 51}

Electrophilic substitution of trimethylstannyl-group under the treatment with molecular halogens of trimethylstannyl trifluoroacetylacetylene $\mathbf{1 8 0}$ was used for the preparation of halogenderivatives of trifluoroacetylacetylenes 181. The acetylene 180 can be prepared using the reaction of bis- trimethylstannylacetylene $\mathbf{1 7 9}$ and TFAA. Analogous synthesis of parent trifluoroacetylacetylene was proposed by the reaction with trifluoroacetic acid. ${ }^{74}$

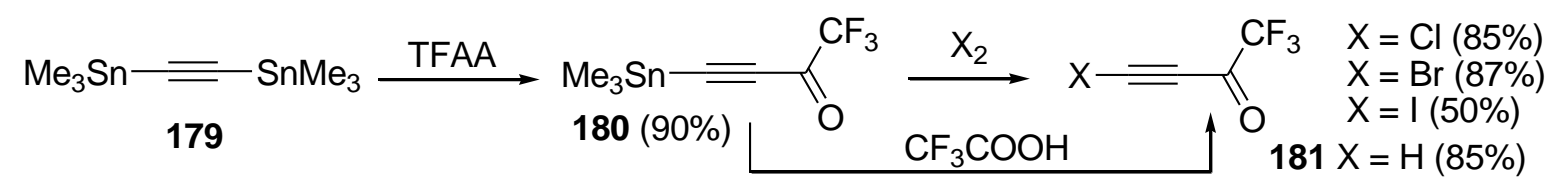

\section{Scheme 52}

1,4-Addition of dialkylcuprates to acetylenic ketones $\mathbf{1 8 2}$ is highly regioselective but it is not stereoselective and gives products $\mathbf{1 8 3}$ in moderate yields. The application of cyanocuprates results in higher yields and in a nearly $100 \%$ regioselectivity of the reaction. However, in some cases cyanohydrins are the products of the reaction. ${ }^{75}$ The reactions of alkynyl trifluoromethyl ketones with aromatic amines afford $\beta$-amino-substituted $\mathrm{CF}_{3}$-enones 185 in good yields. ${ }^{76}$ 


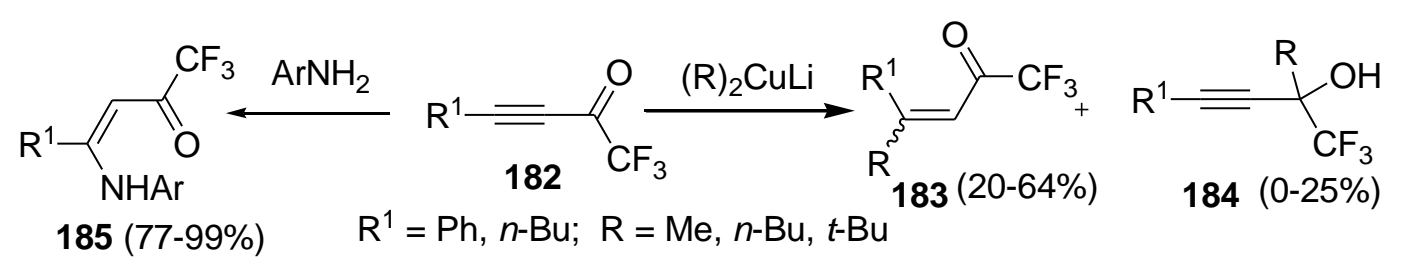

\section{Scheme 53}

\section{Application of $\alpha, \beta$-Unsaturated CF3-Ketones to the Synthesis of Heterocycles}

\subsection{Synthesis of three- and four-membered heterocycles}

The perfluorinated $\mathrm{CF}_{3}$-enone 186 was produced by pyrolysis of perfluorodihydrofuran 187 which in turn is prepared by high temperature hydrolysis of tetrafluoroethene tetramer $\mathbf{1 8 8} .^{77}$ The fluorinated oxirane 189 and azetidine 190 were prepared using the reaction of 186 with $\mathrm{NaOCl}$ and primary amines correspondingly.

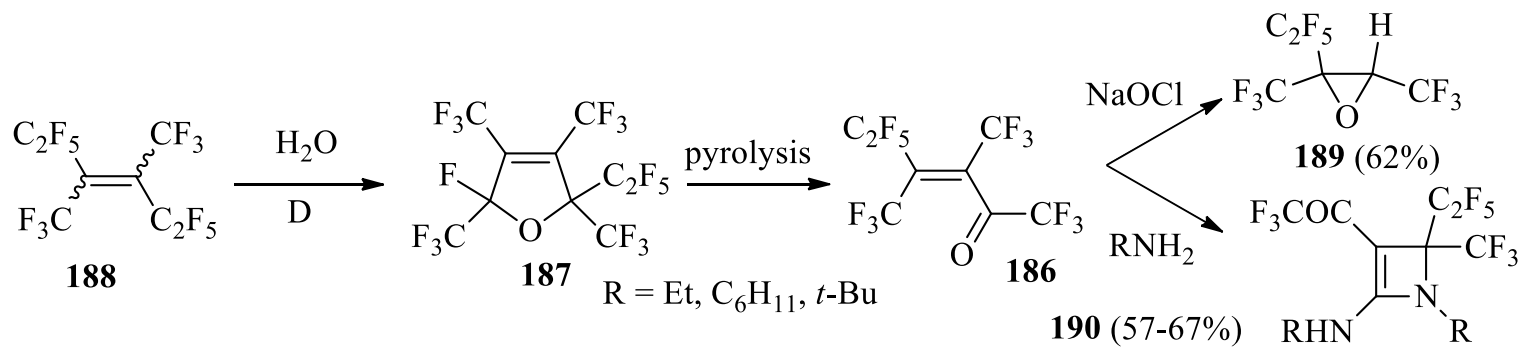

\section{Scheme 54}

3.1.1 Synthesis of pyrrole derivatives. The reaction of diethoxyenone 191 with $\mathrm{NaCN}$ was described for the synthesis of the corresponding pyrrolidone $192 .{ }^{78}$ It was shown that various enones 193 react with $\mathrm{NaCN}$ to give the corresponding pyrrolidones 194 as the mixture of diastereomers. ${ }^{79}$ Subsequent dehydration proceeds with migration of double bond and leads to formation of pyrroline-3-one-2 195.

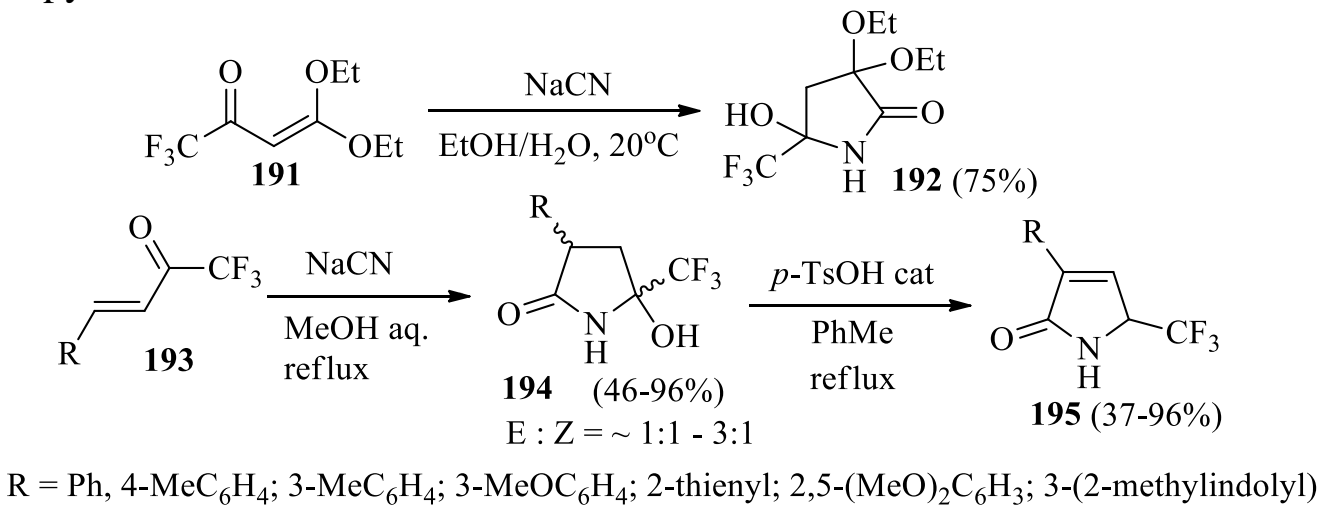

\section{Scheme 55}


Other derivatives of trifluoromethyl pyrrole 196 were prepared using reaction of dithiazole 197 (prepared from Appel salt) with primary amines. ${ }^{80}$

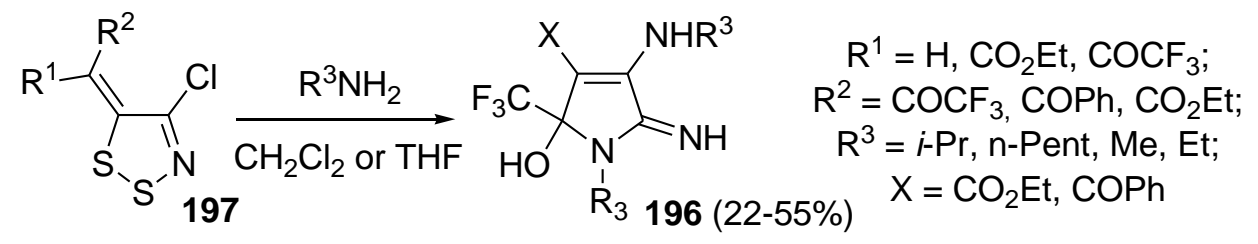

\section{Scheme 56}

Photolytic rearrangement of aziridine-substituted enaminoketones 198 was used for the preparation of the $\mathrm{CF}_{3}$-pyrrole derivatives. ${ }^{81}$ Depending on the substituents of starting ketone 198 the pyrrole 199 or the mixture of diphenylpyrrole 200 and dibenzoindole 201 were formed.

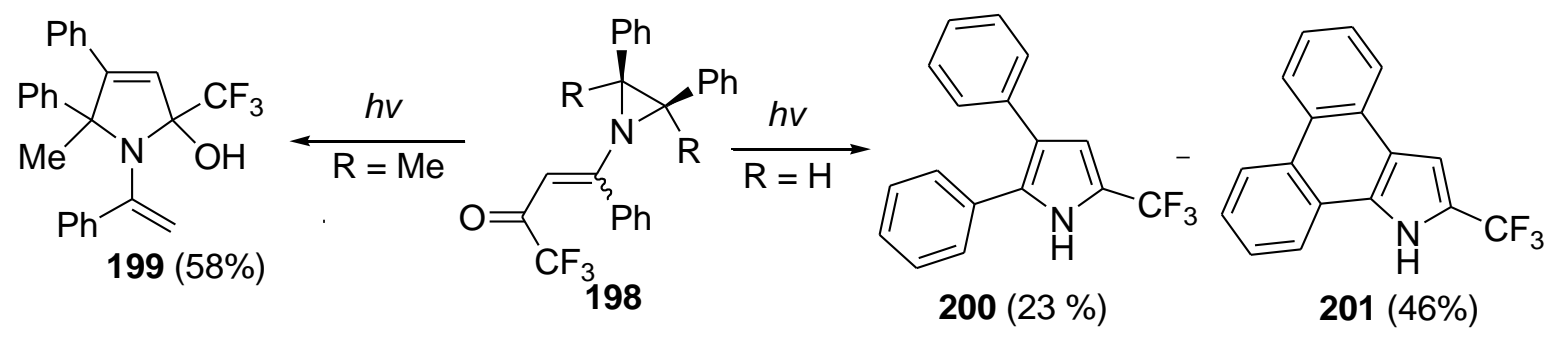

\section{Scheme 57}

The acylation of enaminoketones 202 with oxalyl chloride was applied for the preparation of $1 H$-pyrrole-2,3-diones 203. ${ }^{82}$<smiles>[R7]N/C([R7])=C\C(=O)C(F)(F)F</smiles>

202<smiles>O=C(Cl)C(=O)Cl</smiles>

$\mathrm{R}^{1}=\mathrm{Me}, t-\mathrm{Bu} ; \mathrm{R}^{2}=\mathrm{H}, \mathrm{Ph}$<smiles>[R7]C1=C(C(=O)C(F)(F)F)C(=O)C(=O)N1</smiles>

$\mathrm{R}^{2} 203$

\section{Scheme 58}

Novel approach for the synthesis of alkoxy and amino pyrrole derivatives 204a,b has been elaborated using the reaction of azidomethylenones $\mathbf{2 0 5 a}, \mathbf{b}$ with trimethylphosphine. ${ }^{83}$ 


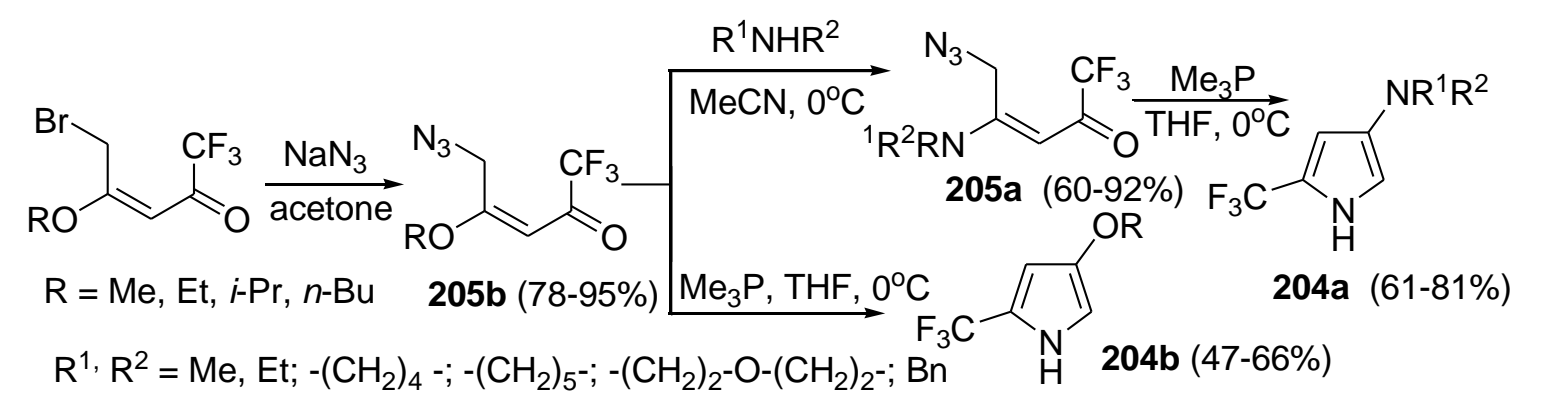

\section{Scheme 59}

The viability of a reaction sequence based on the reaction of $\alpha$-amino acids with the alkoxy enone 206 followed by a cyclization promoted by TFAA was established. ${ }^{84}$ All steps of the synthesis can be done in one-pot to give various $\mathrm{CF}_{3}$-pyrroles $\mathbf{2 0 7}$ including condensed pyrroles.

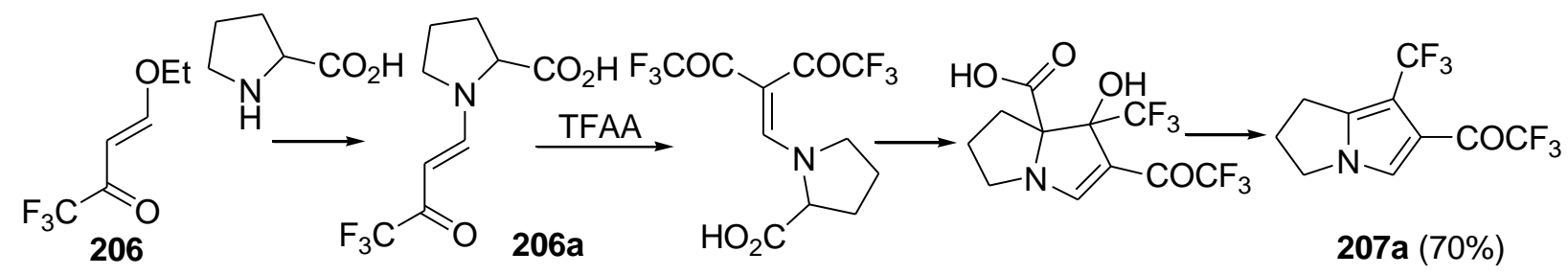<smiles>CCOC(=O)c1c(C(F)(F)F)c(C(=O)OC(F)(F)F)cn1Cc1ccccc1</smiles>

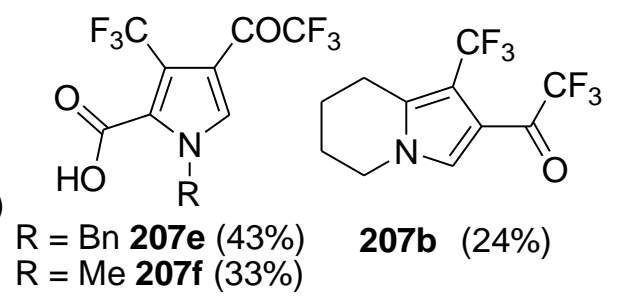<smiles>O=C(c1cn2c(c1C(F)(F)F)CSC2)C(F)(F)F</smiles><smiles>FC(F)(F)c1ccn2c1CSC2</smiles>

\section{Scheme 60}

Dimethoxyethylamine substituted enaminones 208 can be cyclized easily in the presence of TFA to the corresponding 3-trifluoroacetylpyrroles 209 in good yield. ${ }^{85}$

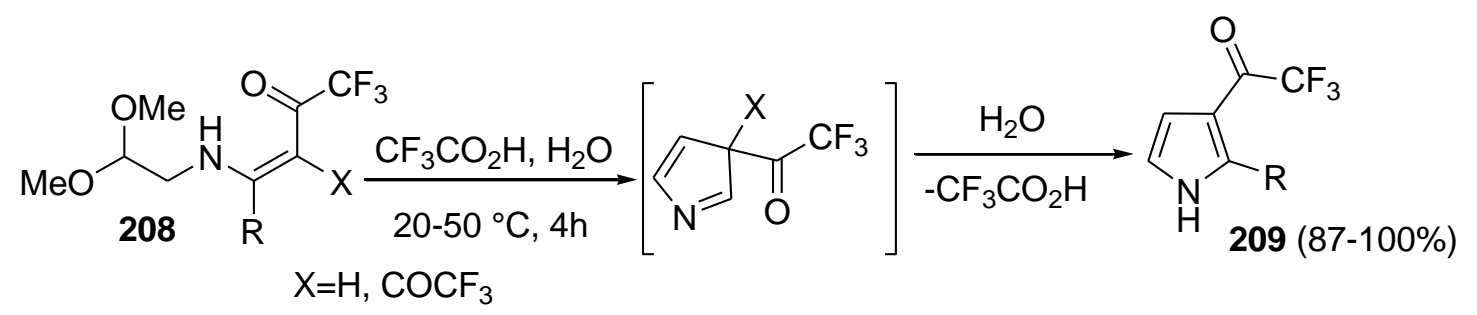

\section{Scheme 61}

Imino-derivative of unsaturated trifluoromethyl-containing ketones $\mathbf{2 1 0}$ was cyclized in the presence of palladium on carbon to 5-trifluoromethylpyrrolidone $211 .{ }^{28}$ 
<smiles>COC(=O)/C=C\C(=Nc1ccc(C)cc1)C(F)(F)F</smiles>

\section{Scheme 62}

$\alpha, \beta$ - Unsaturated ketones are efficient dipolarophiles in catalytic asymmetric 1,3-dipolar cycloaddition with azomethine ylides 212. The efficiency of this protocol strongly relies on the use of CuI-Fesulphos catalysts, leading to highly functionalized $\mathrm{CF}_{3}$-substituted pyrrolidine $\mathbf{2 1 3}$ in good yields, moderate to high endo/ exo-selectivities and high enantiocontrol (81-96\% ee) ${ }^{86}$

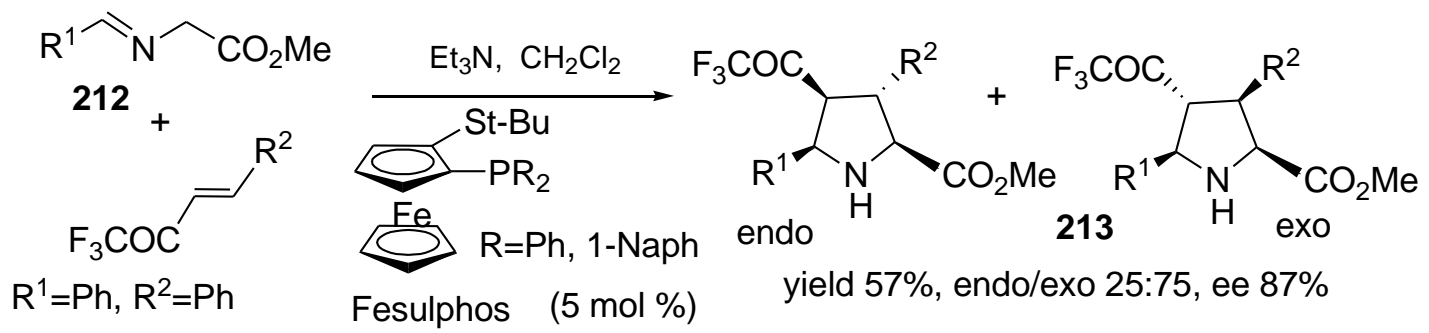

\section{Scheme 63}

A new one-pot strategy for the synthesis of 3-trifluoroacetyl pyrroles 214 was elaborated. ${ }^{87}$ The reaction of $\mathbf{2 1 5}$ with primary amines followed by oxidation with PCC leads to 1,1,1-trifluoro-3-(2ethanal)-4-alkylaminobut-3-en-2-ones cyclizing to pyrroles 214.

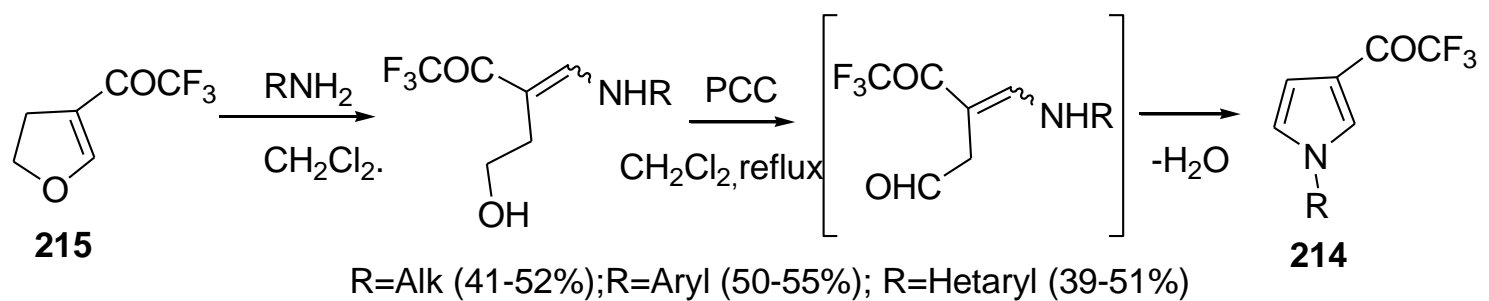

\section{Scheme 64}

Reaction of $\mathrm{CF}_{3} \mathrm{CO}$-substituted primary ketene $N, O$-acetals 216 with 1,2,4,5-tetrazine-3,6dicarboxylate 217 yields by [4+2] cycloaddition tetrafunctionalized pyridazines 218 converted into aminopyrrole derivatives 219 under reductive conditions. ${ }^{88}$ 


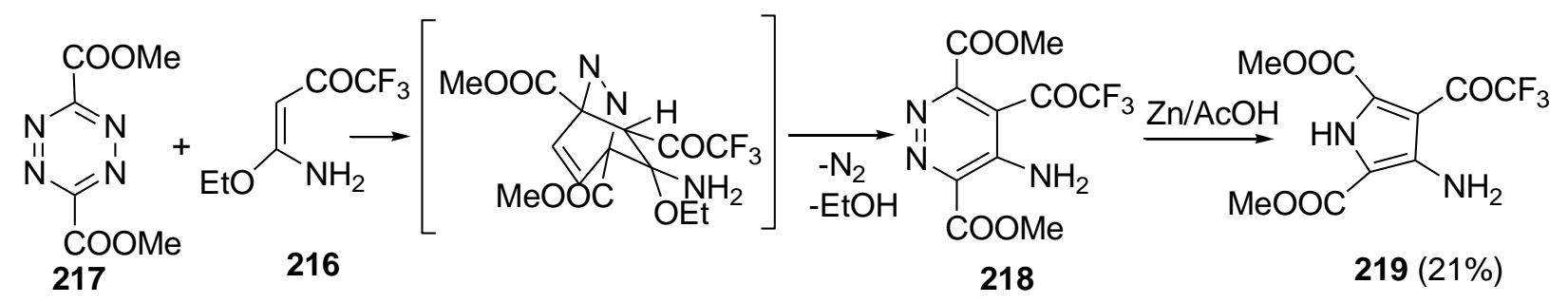

\section{Scheme 65}

3.1.2 Synthesis of furan derivatives. The oxidative dimerization of acetylenic ketone $\mathbf{2 2 0}$ under the treatment with $\mathrm{PbO}_{2}$ results in formation of substituted furan 221 bearing $\mathrm{CF}_{3}-$ and $\mathrm{COCF}_{3}$ groups in moderate yields. ${ }^{89}$

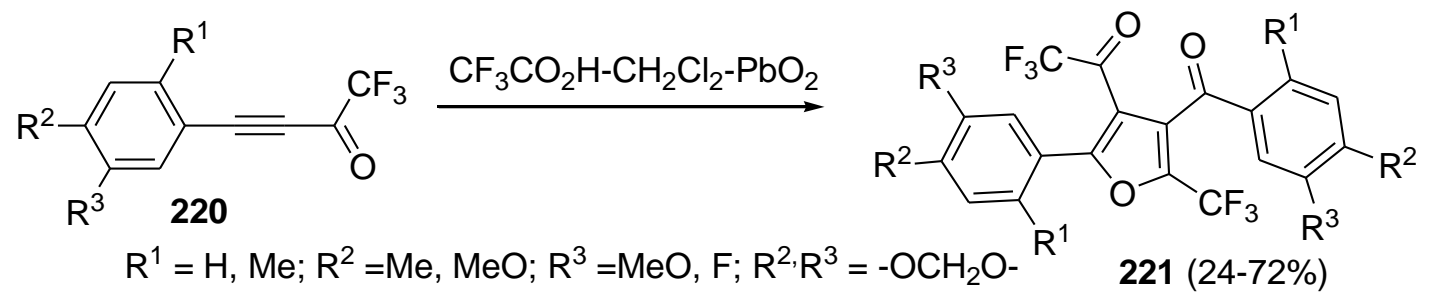

\section{Scheme 66}

Trifluoromethyl furan derivatives $\mathbf{2 2 2}$ were prepared by reaction of dithiazole $\mathbf{2 2 3}$ with secondary amines. ${ }^{80}$

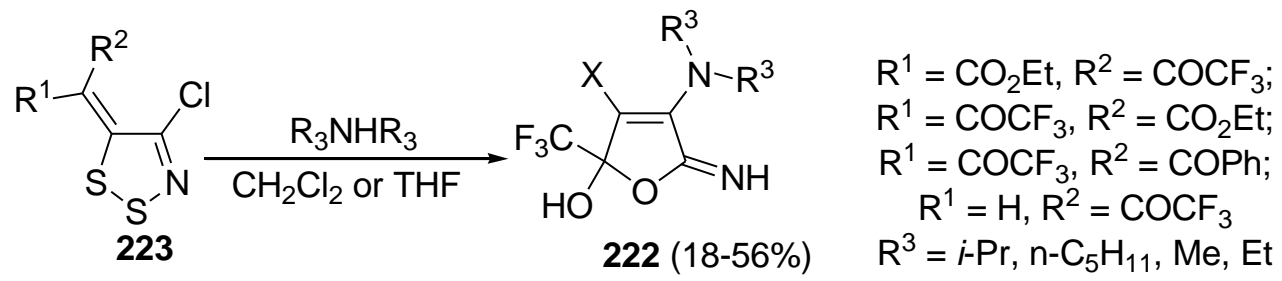

\section{Scheme 67}

The reaction of $\gamma$-hydroxy enone $\mathbf{2 2 4}$ with thiophenol leads to tetrahydrofuran derivative $\mathbf{2 2 5}$. The compound 225 eliminates water and thiophenol to give the corresponding furan $\mathbf{2 2 6}{ }^{68 \text { a }}$

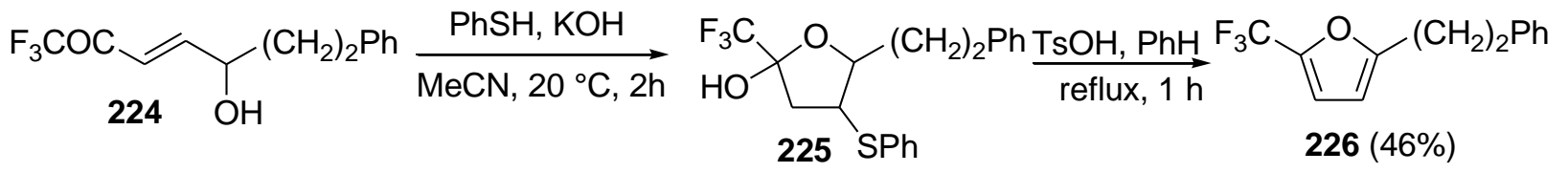

\section{Scheme 68}


The reaction of $\mathbf{2 2 7}$ with isocyanides occur at room temperature without catalysts to give stable 1,4-cycloaddition products - substituted dihydrofurans $\mathbf{2 2 8} . .^{90}$

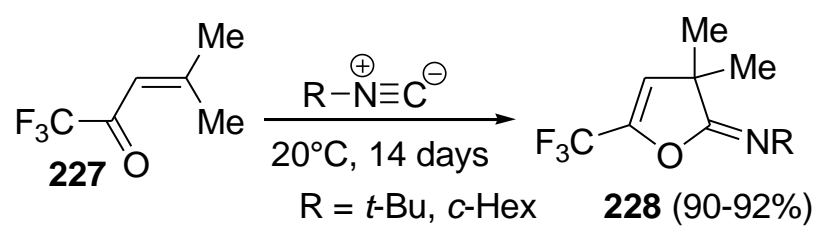

\section{Scheme 69}

The ketones 229 were iodinated and subsequently reduced to give the corresponding alcohols 231 which are then subjected to coupling with phenylacetylene to furnish alcohols 232. Final cyclization by means of AgOTf leads to 2-(trifluoromethyl)furans 233 in fair yield. ${ }^{91}$

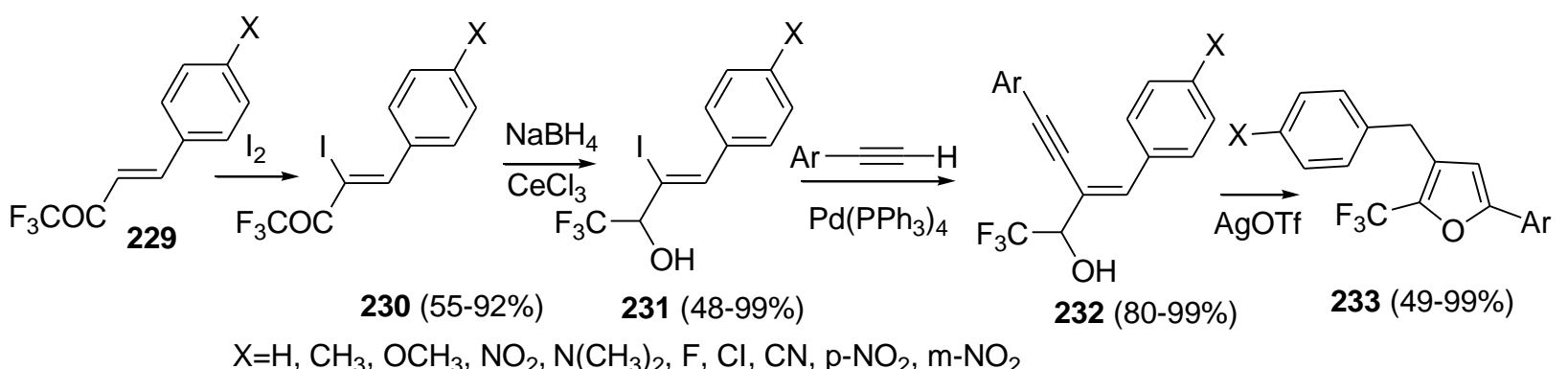

\section{Scheme 70}

3.1.3 Synthesis of thiophene derivatives. Acetylenic ketone 234 was successfully applied as starting compound for preparation of 3-CF 3 -thiophene-2-carboxylates 235 by reaction with methyl thioglycolate. ${ }^{72}$ The cyclization of sulfide derivatives $\mathbf{2 3 6}$ in the presence of a base demonstrated the formation of $237.9^{92}$

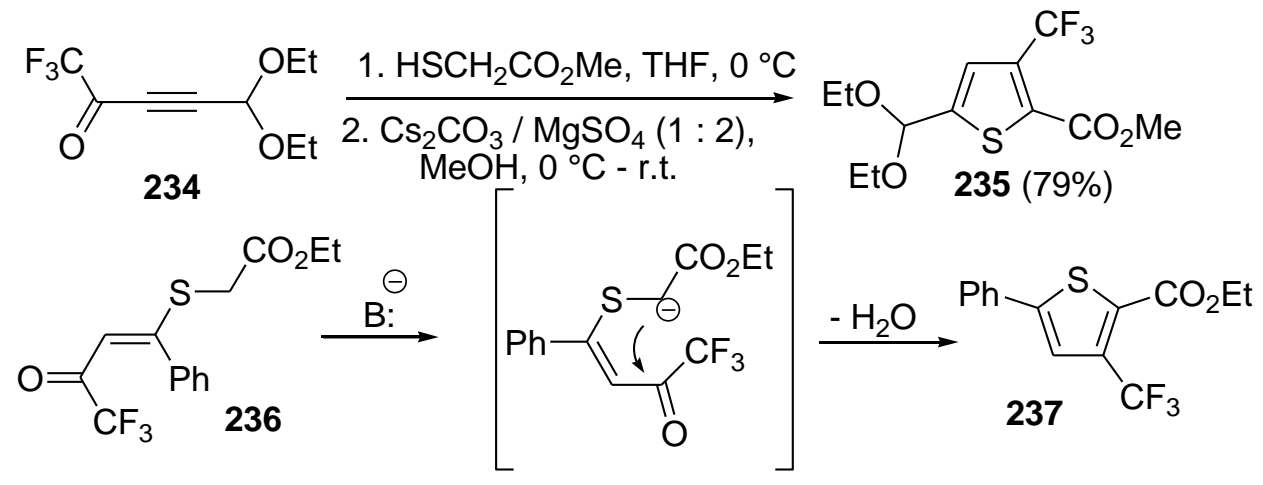

\section{Scheme 71}


3.1.4 Synthesis of pyrazoles and their derivatives. The first example of using a trifluoromethyl enone ( $\beta$-trifluoroacetylstyrene) for the synthesis of pyrazole derivatives dates back to $1959 .{ }^{25}$ However, vigorous studies of the reactions of $\mathrm{CF}_{3}$-enones have been investigated only in recent years. ${ }^{93}$ The reactions of ketone 238 with $\mathrm{N}$-substituted hydrazines depending on structure of starting hydrazine lead to individual pyrazole or to the mixture of regioisomers 239 and 240.

\section{Scheme 72}<smiles>CCNC=C(C(=O)C(F)(F)F)c1ccccc1</smiles>

238<smiles>[R20]n1cc(-c2ccccc2)c(C(F)(F)F)n1</smiles>

$\mathrm{R}=4-\mathrm{NO}_{2} \mathrm{C}_{6} \mathrm{H}_{4},(0 \%)$

$\mathrm{R}=\mathrm{Ph},(7 \%)$

$\mathrm{R}=\mathrm{Me},(58 \%)$<smiles>[R]n1ncc(-c2ccccc2)c1C(F)(F)F</smiles>

240

$(23 \%)$

The reactions of hydrazines with $\beta$-alkoxy-substituted enones have been investigated. ${ }^{94}$ The reaction of 241 with $\mathrm{N}$-methylhydrazine gives two isomeric dihydropyrazoles 242 and 243 in various ratios. These pyrazolines undergo dehydration to form pyrazoles 244 and 245.
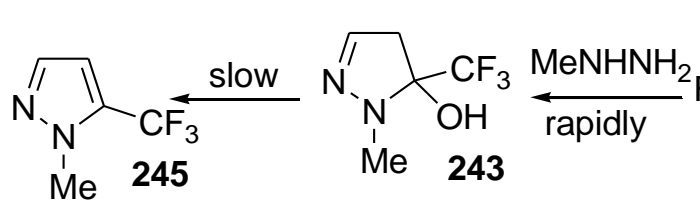<smiles>[Z10]O/C=C/C(=O)C(F)(F)F</smiles><smiles>CC(C)N1C=CC(O)(C(F)(F)F)N1</smiles><smiles>Cn1ccc(C(F)(F)F)n1</smiles>

\section{Scheme 73}

Depending on condition applied the reactions of $\beta$-methoxy- $\mathrm{CF}_{3}$-enones $\mathbf{2 4 6}$ with phenylhydrazine give pyrazoles $\mathbf{2 4 7 , 2 4 8}$ or pyrazoline $\mathbf{2 4 9} .^{95}$

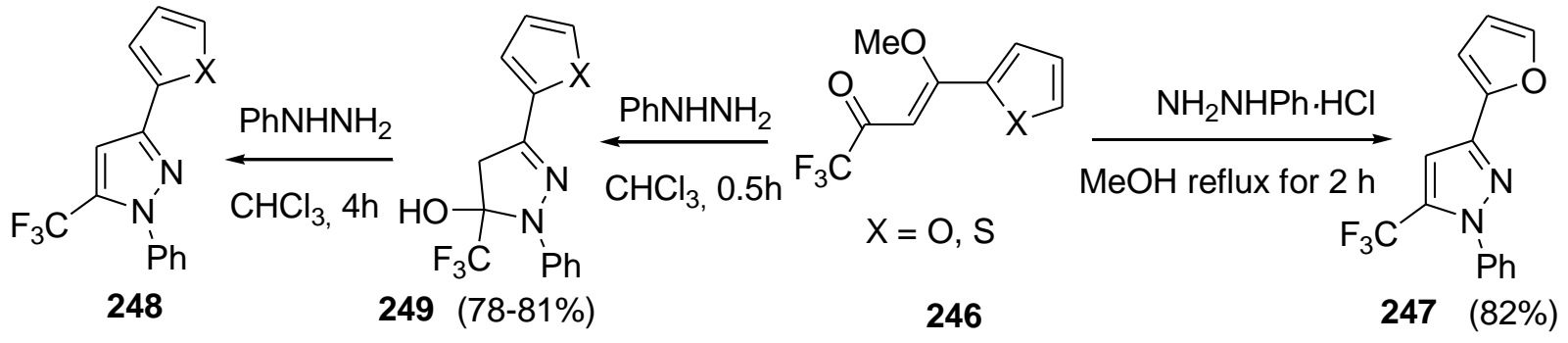

\section{Scheme 74}

The reaction of 4-hydrazo-7-chloroquinoline 250a with 251 was investigated for antimalarial screening of $\mathbf{2 5 2}$ and 253. The corresponding pyrimidine derivatives $\mathbf{2 5 5}$ containing dihydropyrazole substituent are potential analgesics and antipyretics. Similarly prepared 
trifluoromethyl substituted pyrazolines 256a,b exhibit antimicrobial activity against yeast, fungi, bacteria, and alga. The compounds bearing indole moiety 256c were found dual inhibitors of cyclooxygenases (COXs ) and lipoxygenases (LOXs). ${ }^{96}$
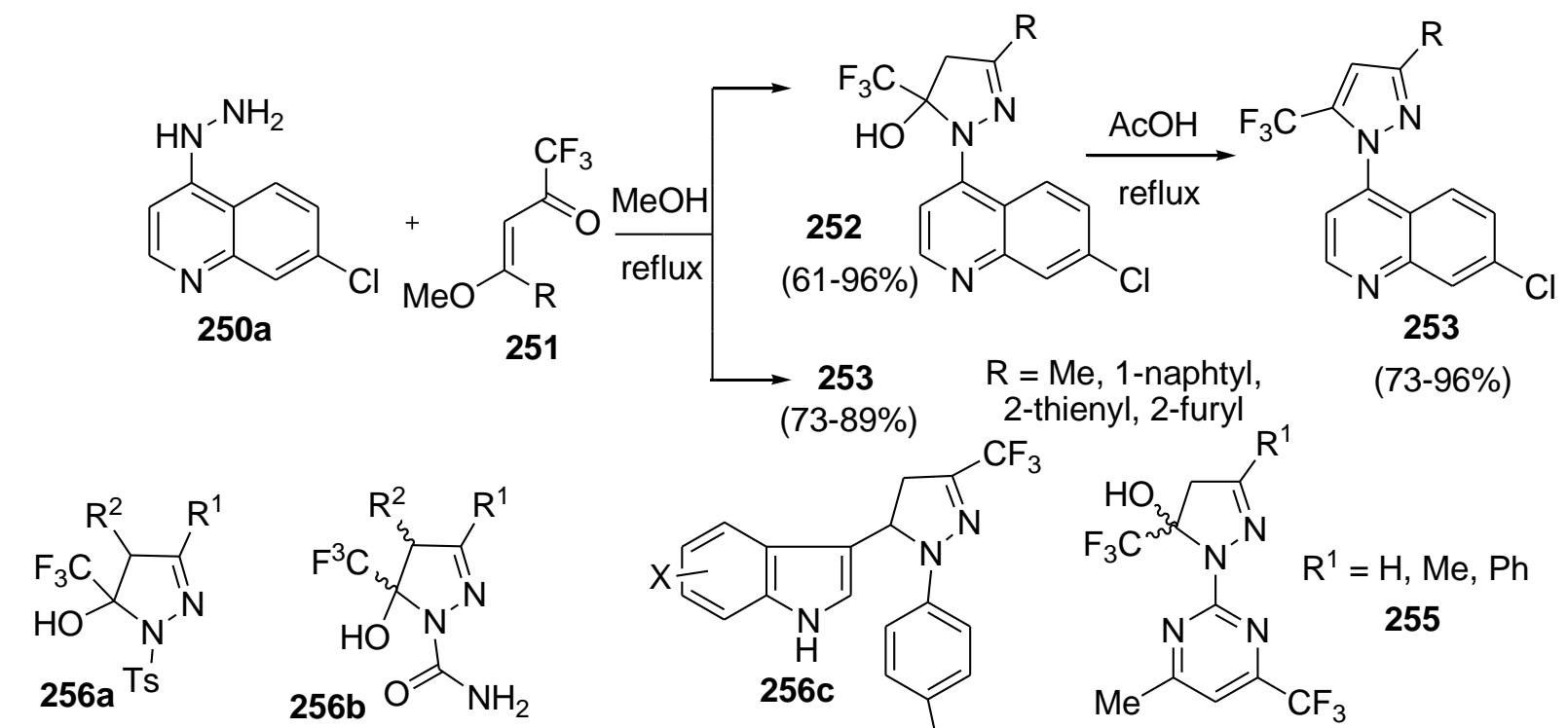

$\mathrm{X}=\mathrm{H}, \mathrm{Hal}, \mathrm{NO}_{2}, \mathrm{NH}_{2}, \mathrm{CN}, \mathrm{OMe}, \mathrm{COOH}, \mathrm{CH}_{3} \quad \mathrm{R}^{2}=\mathrm{H}, \mathrm{Ph} \quad \mathrm{SO}_{2} \mathrm{NH}_{2}$
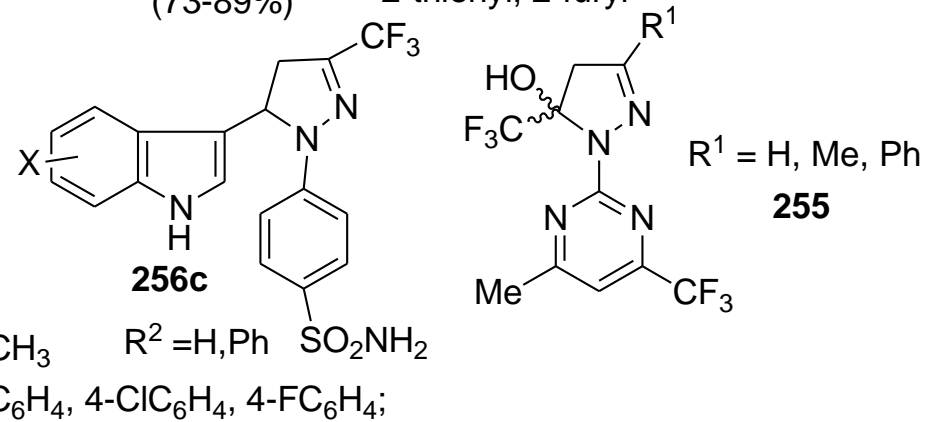

$\mathrm{R}^{1}=\mathrm{H}, \mathrm{Ph}, 4-\mathrm{MeC}_{6} \mathrm{H}_{4}, 4-\mathrm{MeOC}_{6} \mathrm{H}_{4}, 4-\mathrm{BrC}_{6} \mathrm{H}_{4}, 4-\mathrm{ClC}_{6} \mathrm{H}_{4}, 4-\mathrm{FC}_{6} \mathrm{H}_{4}$;

\section{Scheme 75}

The reactions of various aryl- and hetaryl substituted hydrazines with 257 containing acetyl group in $\alpha$-position lead the heterocyclization is directed to acetyl-group for arylhydrazines and to trifluoroacetyl-group for methylhydrazine to form pyrazoles $\mathbf{2 5 8}, \mathbf{2 5 9} .{ }^{97}$

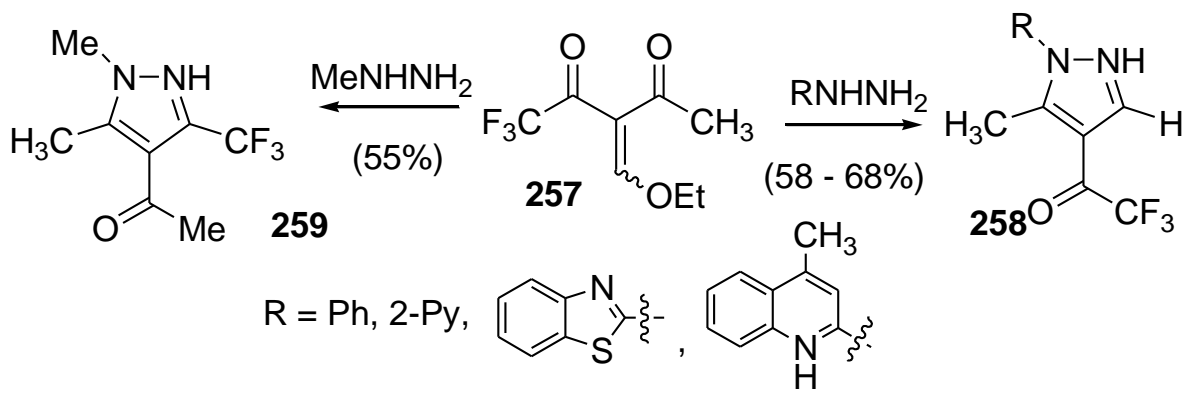

\section{Scheme 76}

The pathway of the reaction for ketone $\mathbf{2 6 0}$ with perfluorophenylhydrazine due to its reduced basicity differs from that of reaction with phenylhydrazine. The reaction of $\mathbf{2 6 0}$ with phenylhydrazine leads to pyrazole $\mathbf{2 6 1}$ while the same reaction with pentafluorophenylhydrazine leads to the formation of pyrazoline $\mathbf{2 6 2}$ dehydrated into $\mathbf{2 6 3}$ using $\mathrm{P}_{2} \mathrm{O}_{5} .{ }^{98}$ 
<smiles>FC(F)(F)c1ccnn1C(F)(F)F</smiles>

$263(65 \%)$

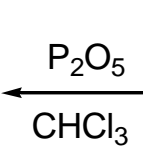

$\mathrm{CHCl}_{3}$

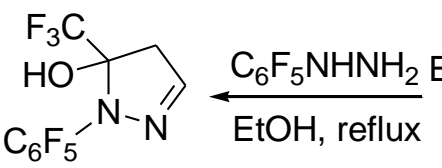

$262(80 \%)$

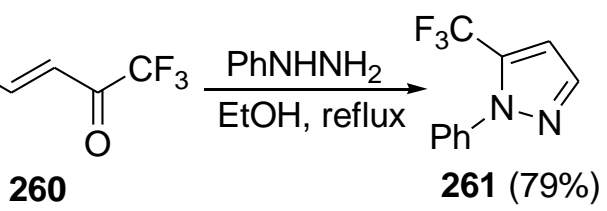

\section{Scheme 77}

Ethoxy-, hydroxy- and aminopyrazole derivatives 265 were obtained in good yields by the reaction of diethoxyenone $264\left(\mathrm{O}, \mathrm{N}\right.$-acetals-aminals of 266) with hydrazines. ${ }^{78,99}$

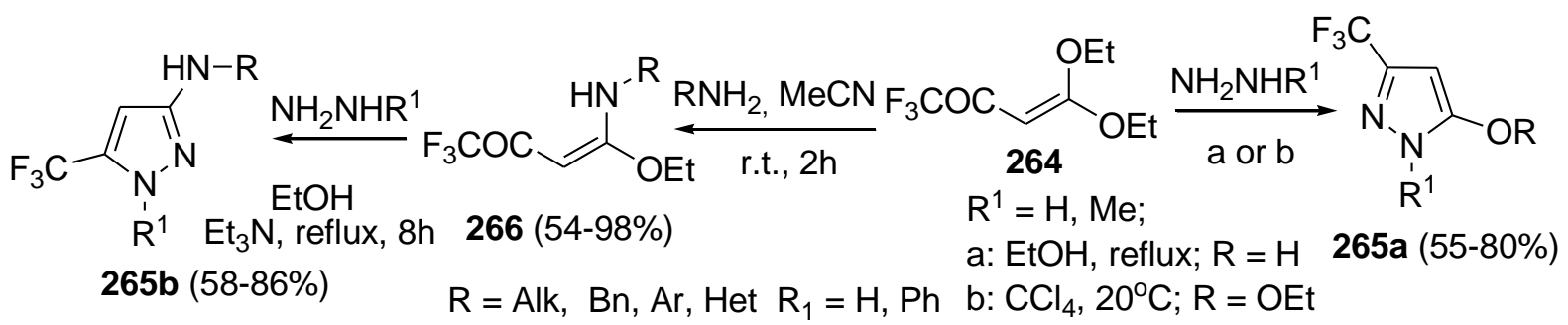

\section{Scheme 78}

The reaction of $\alpha$-bromo- $\beta$-ethoxy- $\mathrm{CF}_{3}$-enone $\mathbf{2 6 7}$ with aryl hydrazines proceeds $100 \%$ regioselectively to open new effective way to the synthesis of 4-bromo-5- $\mathrm{CF}_{3}$-pyrazoles $\mathbf{2 6 8}{ }^{100}$

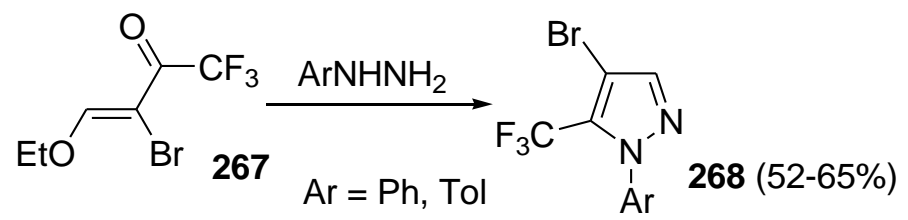

\section{Scheme 79}

Isomeric 5-chloro (bromo) substituted pyrazoles 272 were prepared by the reaction of $\beta, \beta$ dihalogen-substituted trifluoromethylketones 269 with $N, N$-dimethylhydrazine. ${ }^{101}$ The mechanism of the reaction consists of initial dimethylhydrazone $\mathbf{2 7 0}$ formation with subsequent intramolecular attack of nucleophilic fragment on $\beta$-carbon atom of vinyl group and demethylation of 271 with dimethylhydrazine. Isomeric salts $\mathbf{2 7 3}$ with potential high herbicide activity were prepared in the reaction of enones $\mathbf{2 7 4}$ with $N, N^{\prime}$-dimethylhydrazine. ${ }^{102}$ 


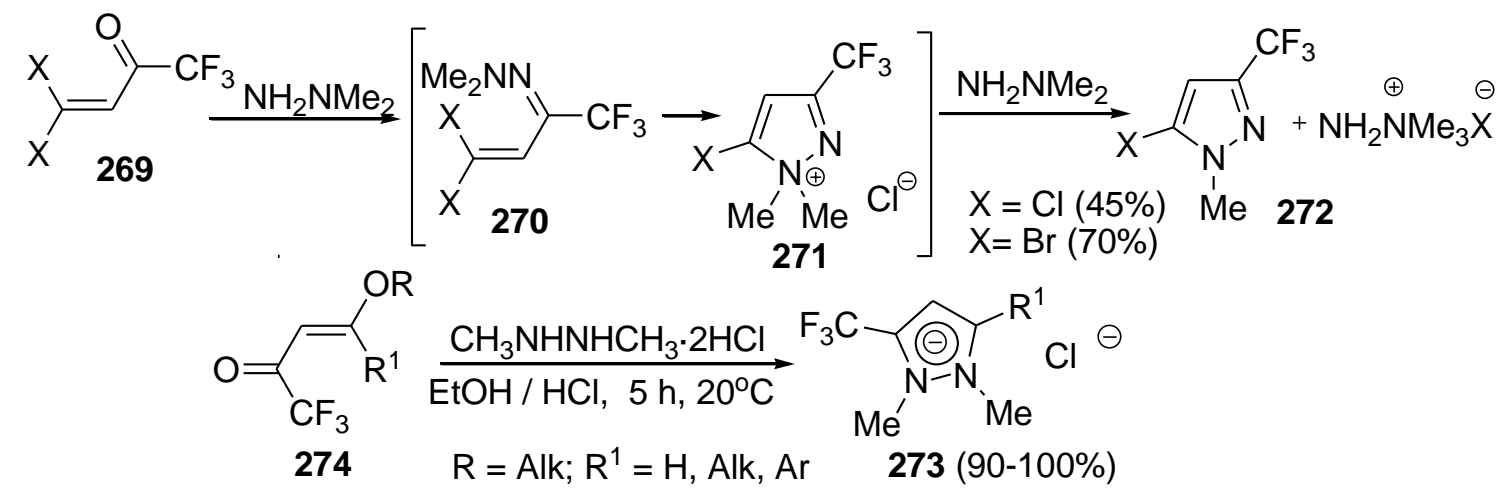

\section{Scheme 80}

An interesting example of application of trifluoroacetyl pyrroline 275 for preparation of pyrazoles 276 was described. ${ }^{103}$ In view of the pharmacological interest in heterocycles bearing both $\mathrm{CF}_{3}$-appendage and $\beta$-aminoethyl side chain the method is very attractive. The reaction of cyclic enaminoketones 277 with hydrazine leads to pyrazoles 278 containing aminoalkyl side chain. ${ }^{27 \mathrm{~b}}$ The reaction of hydrazine with $\beta$-trifluoroacetyldihydropyran and $\beta$ trifluoroacetyldihydrofuran $\mathbf{2 7 9}$ leads to the corresponding pyrazole $\mathbf{2 8 0} .^{71 \mathrm{~b}}$

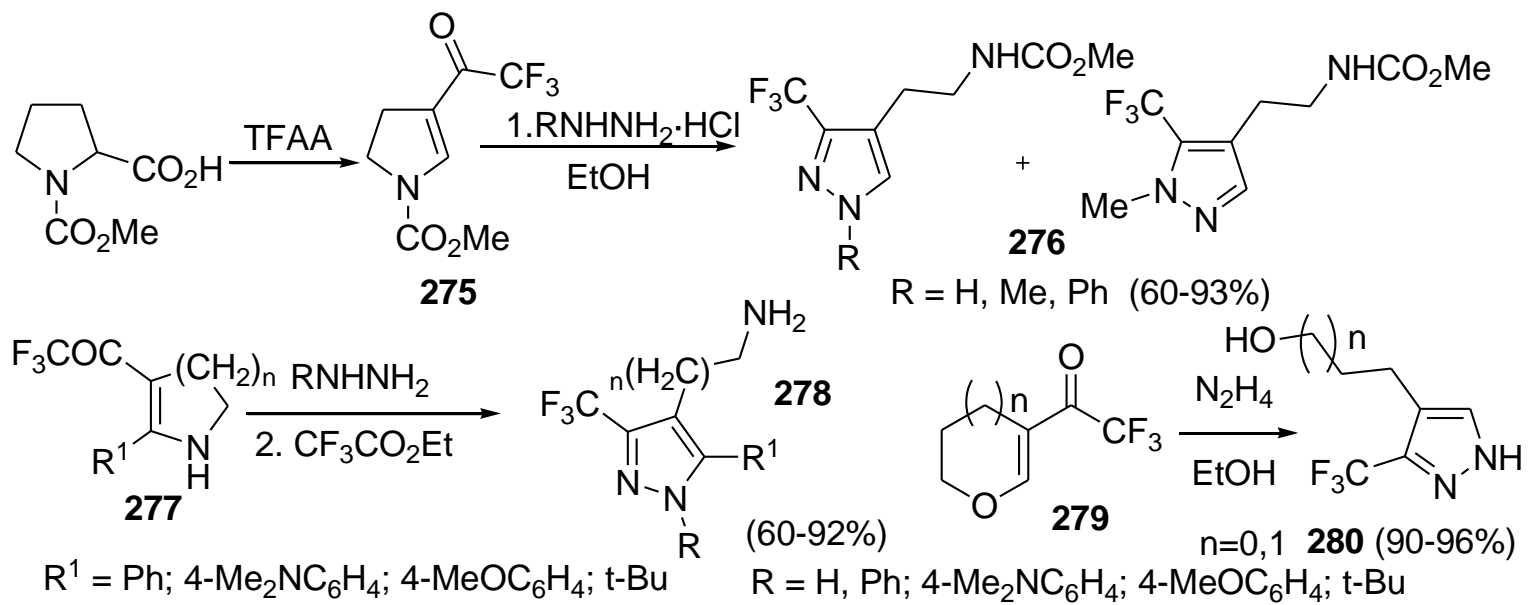

\section{Scheme 81}

Similarly the pyrazoles 282 containing 1,3-dithiopropyl substituent were prepared from $\mathrm{CF}_{3}$ enones containing a dialkyldithio-fragment in the $\beta$-position 281. ${ }^{104}$

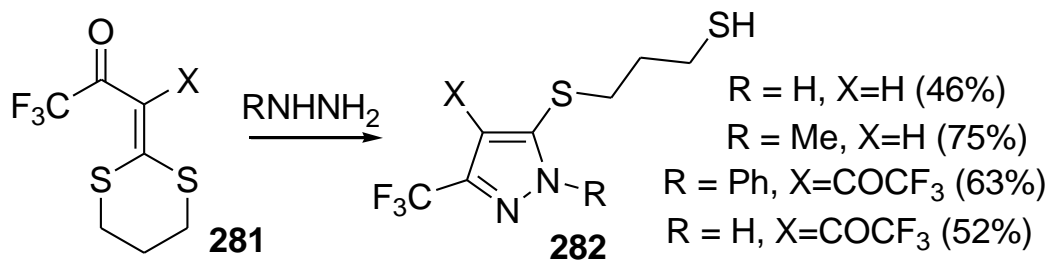

\section{Scheme 82}


An efficient synthesis of 1-cyanoacetyl-5-trifluoromethyl-4,5-dihydro-1H-pyrazoles 283 in the ionic liquid ([bmim] $\left.\left[\mathrm{BF}_{4}\right]\right)$ has been reported. ${ }^{105}$

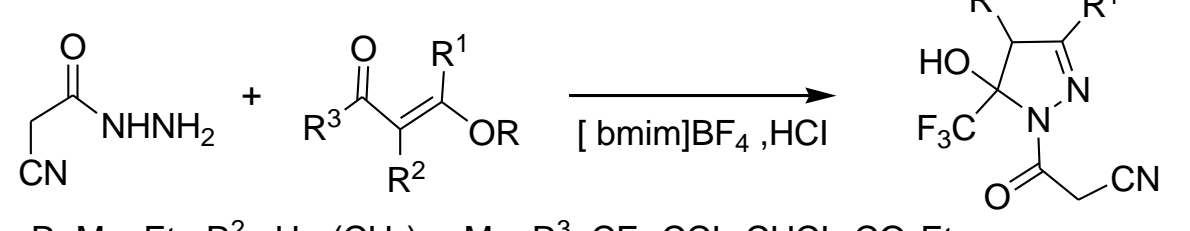

$\mathrm{R}=\mathrm{Me}, \mathrm{Et} ; \mathrm{R}^{2}=\mathrm{H},-\left(\mathrm{CH}_{2}\right)_{4^{-}}, \mathrm{Me} ; \mathrm{R}^{3}=\mathrm{CF}_{3}, \mathrm{CCl}_{3}, \mathrm{CHCl}_{2}, \mathrm{CO}_{2} \mathrm{Et} \quad 28362-90 \%$

\section{Scheme 83}

Using double excess of ketones 284 in the reaction with aminoguanidine carbonate the formation of pyrazolinepyrimidines $\mathbf{2 8 5}$ is observed. These compounds can be easily dehydrated into the corresponding pyrazolylpyrimidines $\mathbf{2 8 6}$. $^{106}$<smiles>[R]/C(=C/C(=O)C(F)(F)F)OC</smiles>

$284 \mathrm{R}=$ Alk, $\mathrm{Ar}$<smiles>[R]C1=NN(c2nc([R])cc(C(F)(F)F)n2)C(O)(C(F)(F)F)C1</smiles>

$285(39-85 \%)$<smiles>[R]c1cc(C(F)(F)F)nc(-n2nc([R])cc2C(F)(F)F)n1</smiles>

$286(70-76 \%)$

\section{Scheme 84}

The reaction of $\mathbf{2 8 4}$ with thiosemicarbazide leds to the corresponding hydroxy dihydropyrazoles 287 in high yields. ${ }^{107}$ They can be transformed into N-unsubstituted pyrazoles 288 in high yields using acidic hydrolysis. The ketone $\mathbf{2 8 9}$ has the hidden bromoketone fragment; it was applied for forming thiazole connected with pyrazoline 291. ${ }^{108}$<smiles>[R]C([R20])=C([R7])C(=O)C(F)(F)F</smiles>

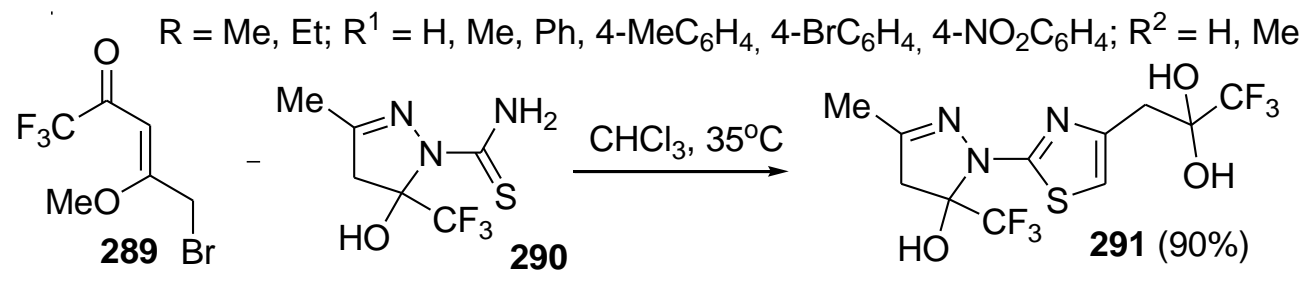

\section{Scheme 85}


The reaction of $\mathbf{2 8 4}$ with 2-pyridylcarboxamidrazone 292 leads to pyrazoline 293. Reaction is accompanied with imine fragment of amidrazone hydrolysis. The compounds 294 react with copper (II) chloride to give 1:1 adducts in which the donor fragment of the molecules is isomerized into their cyclic pyrazolic forms. ${ }^{109}$

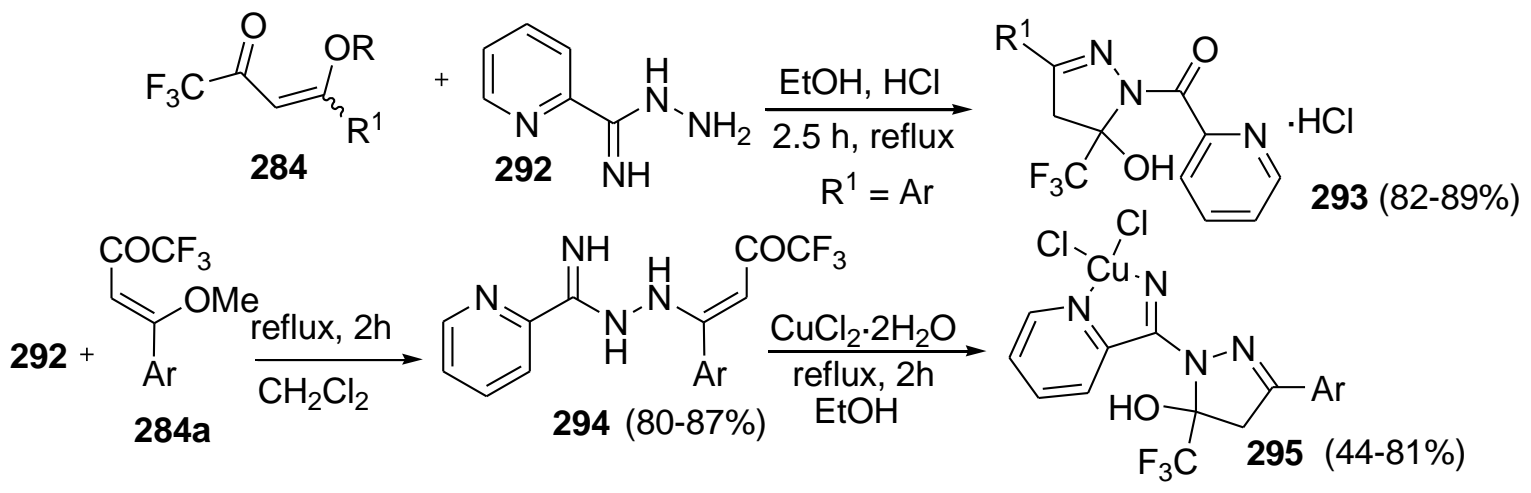

\section{Scheme 86}

Enones 296 containing no replaceable $\beta$-substituents form pyrazolidines 297 which can be dehydrated to the corresponding pyrazolines 298. In case of the reaction of ketone 299 with phenylhydrazine tetrahydropyrazole 300 was obtained 100\% stereoselectively. ${ }^{110}$

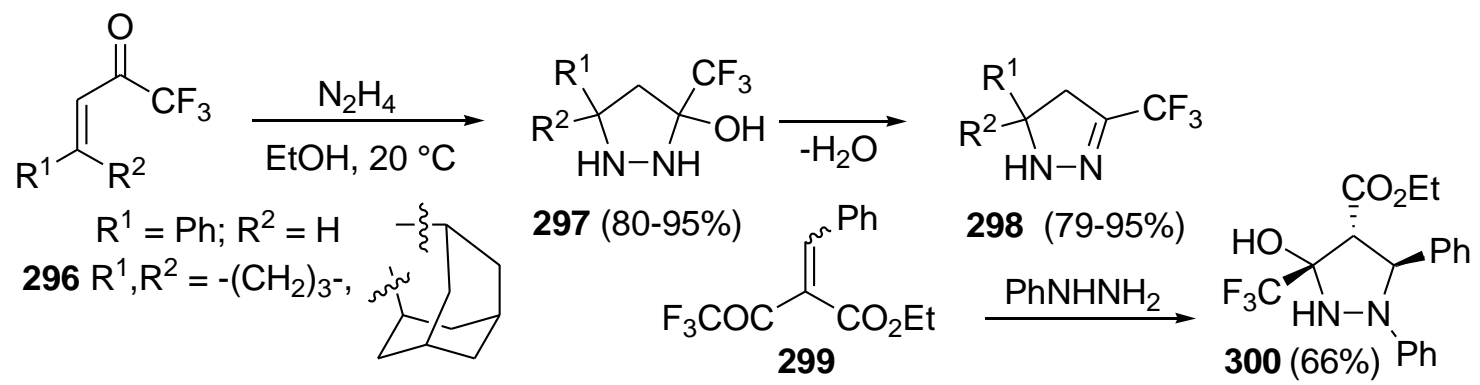

\section{Scheme 87}

$\beta$-Trifluoroacetylstyrene 301 reacts with hydrazines to afford pyrazolines $\mathbf{3 0 2}$. Oxidation of 302 with lead tetraacetate affords the corresponding pyrazole 303 in a moderate yield. ${ }^{111}$ When $\beta$ trifluoroacetylstyrene reacts with methylhydrazine, a mixture of isomeric pyrazolines 305a,b (in $\sim 1$ : 3 ratio) is formed. The reaction with 1,2-dimethylhydrazine gives pyrazolidine. ${ }^{110 a}$ 


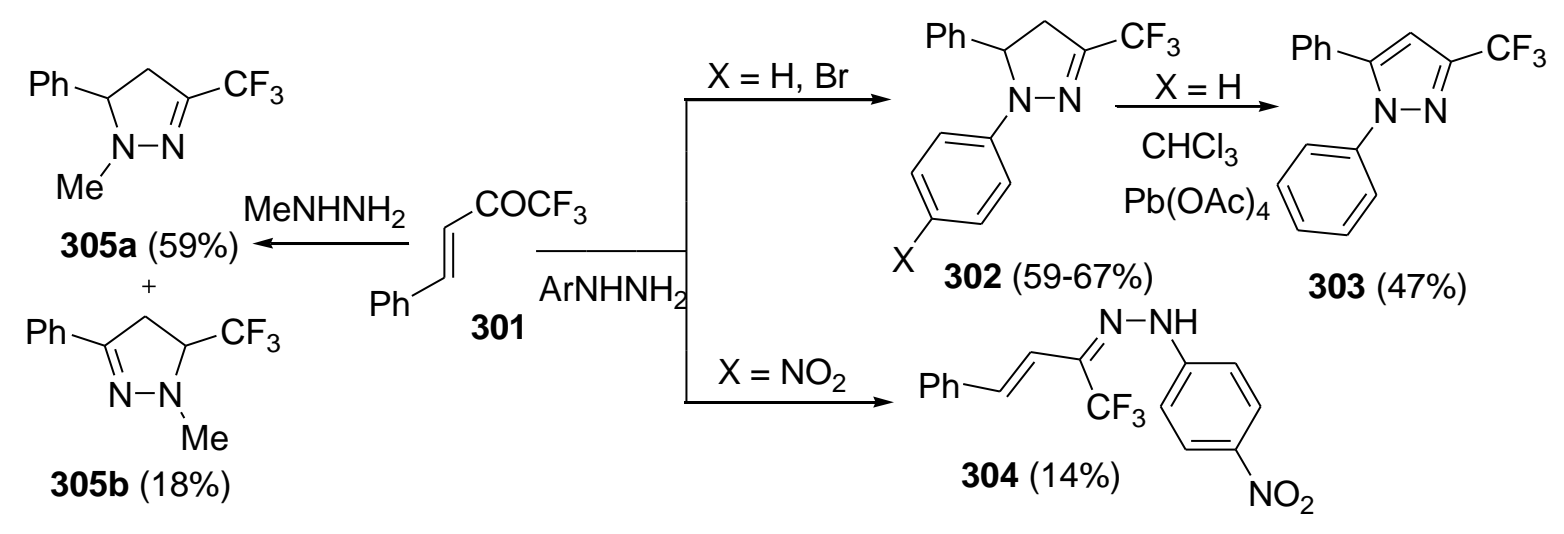

\section{Scheme 88}

Enone 301 reacted with semicarbazide or thiosemicarbazide in an acidic medium to afford semicarbazone 306a or thiosemicarbazone 306b cyclized in the presence of EtONa to 307. ${ }^{112}$

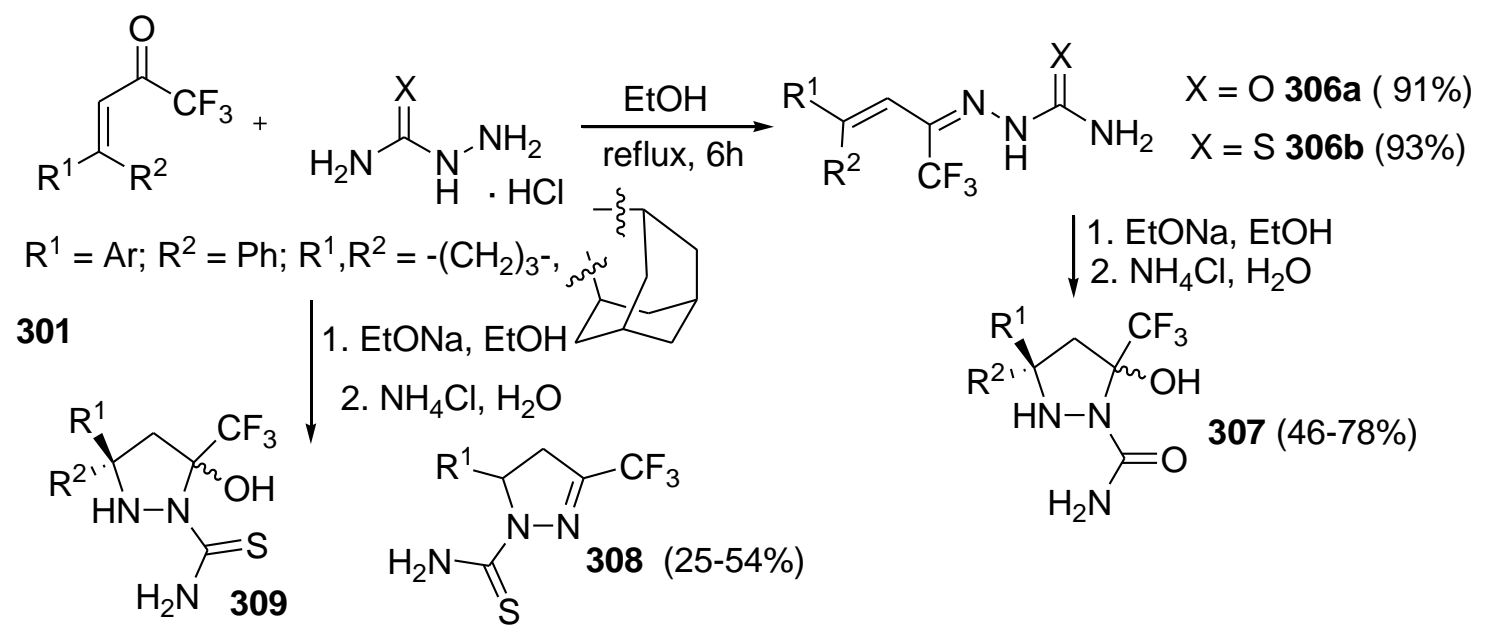

\section{Scheme 89}

The perfluorinated derivative of pyrazolidine $\mathbf{3 1 0}$ was obtained by the reaction of $\mathbf{3 1 1}$ with hydrazine. This product $\mathbf{3 1 0}$ is a stable solid subliming in vacuum without decomposition. ${ }^{77}$

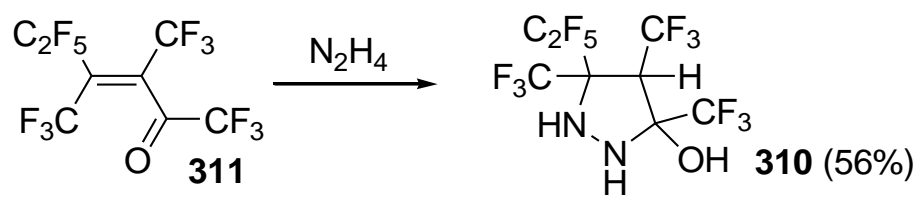

\section{Scheme 90}

The reaction of acetylenic $\mathrm{CF}_{3}$-ketones $\mathbf{3 1 2}$ with hydrazines was also used for the preparation of $\mathrm{CF}_{3}$-substituted pyrazoles 313 in excellent yield. ${ }^{113}$ 


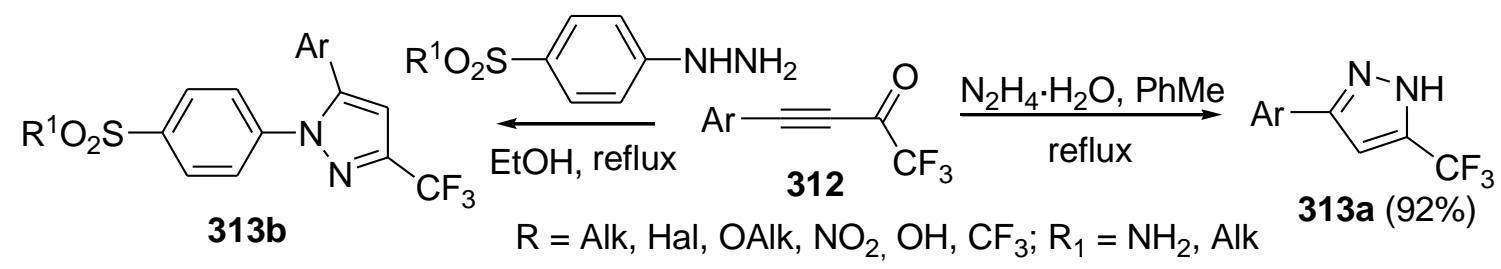

\section{Scheme 91}

tert-Butylhydrazones 314 react with enone 315 giving rise to 4-trifluoroacetylpyrazoles 318 . A possible mechanism includes replacement of the ethoxy group by the hydrazone, subsequent cyclization to pyrazolines 317 and oxidation to pyrazoles 318 by atmospheric oxygen. ${ }^{114}$

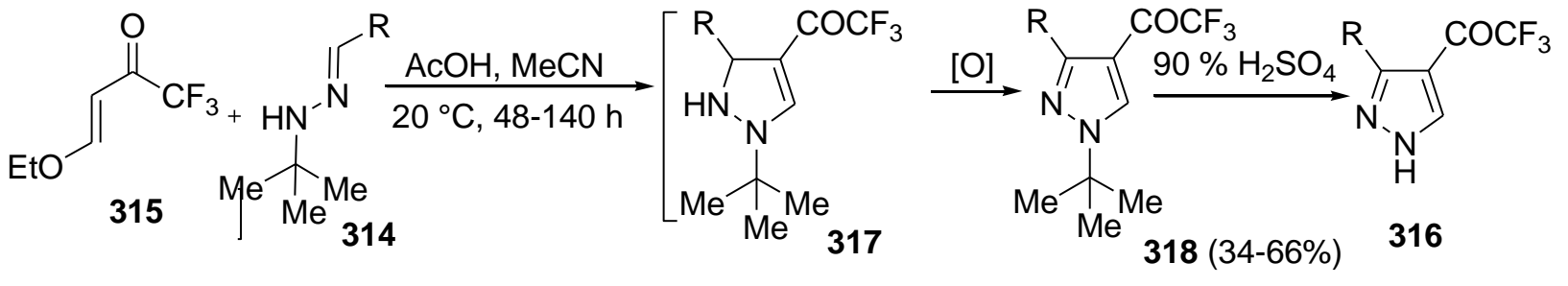

\section{Scheme 92}

The ketones 320 react with diazoalkanes 319 forming pyrazolines 321 100\% regioselectively and highly stereoselectively. Using the trifluoroacetylated acetylene $\mathbf{3 2 2}$ in the reaction with ethyl diazoacetate allows preparing the pyrazole 323. ${ }^{115}$

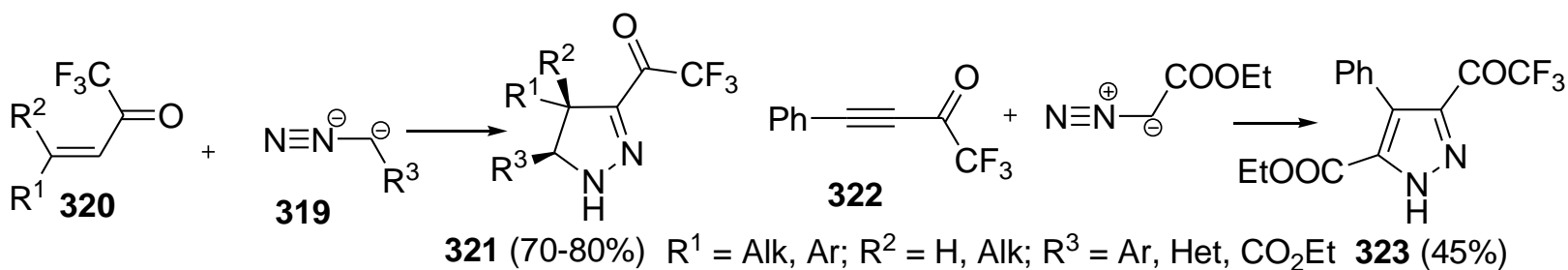

\section{Scheme 93}

3.1.4 Synthesis of isoxazole (isoselenoazole) derivatives. The reactions of $\beta$-alkoxy-substituted enones 324 with hydroxylamine follow different pathways depending on the structure of the enone. Thus acyclic enones and enones containing no oxygen atom in the ring are converted into isoxazolines 325, ${ }^{60 a, 78}$ which can be dehydrated on treatment with $\mathrm{P}_{2} \mathrm{O}_{5}$ or concentrated $\mathrm{H}_{2} \mathrm{SO}_{4}$ to give the corresponding isoxazoles $\mathbf{3 2 6}$ or $\mathbf{3 2 7}$. 


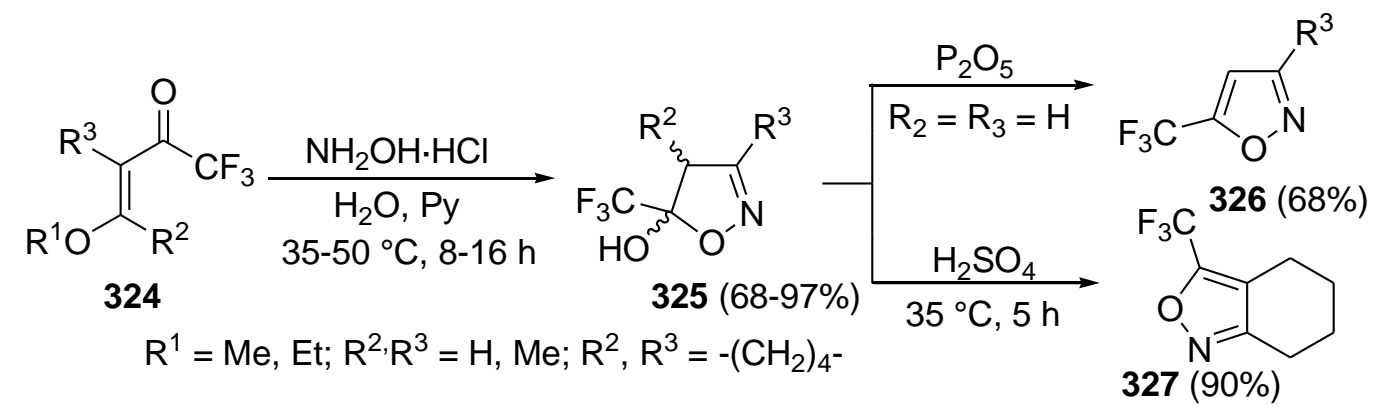

\section{Scheme 94}

$O$-Vinyl oximes 328 react readily with trifluoroacetic anhydride to give $\mathrm{CF}_{3}$-enones $\mathbf{3 2 9}$. 4,5Dihydro-1,2-oxazole 330 was isolated as the single product when the reaction mixture was treated after trifluoroacylation with aqueous $\mathrm{NaHCO}_{3}{ }^{116}$

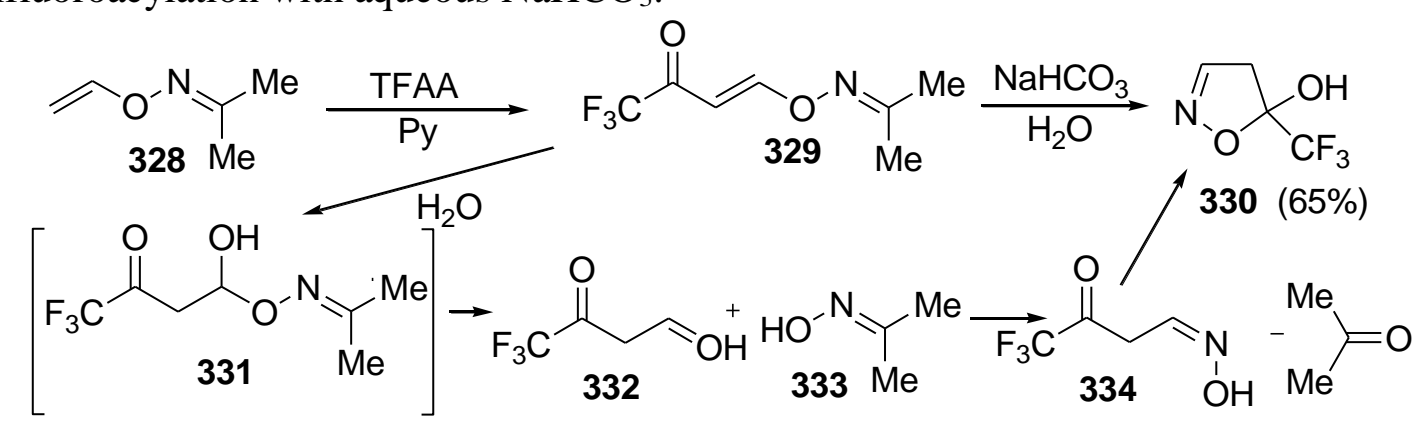

\section{Scheme 95}

The reaction of $\beta$-methoxy $\mathrm{CF}_{3}$-enones 335 with hydroxylamine hydrochloride was investigated. 4,5-Dihydroisoxazoles 336 were obtained in high yields and they can be transformed into the corresponding isoxazoles $\mathbf{3 3 7}$ using concentrated sulfuric acid, or directly using the excess of $\mathrm{HCl}^{117}$

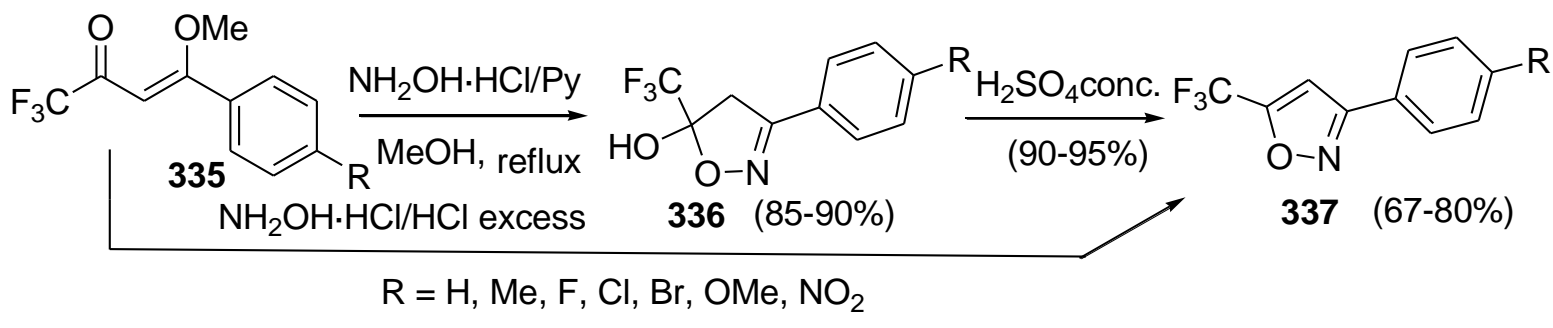

\section{Scheme 96}

The use of cyclic $\beta$-alkoxy- $\mathrm{CF}_{3}$-enone 338 allows preparing isoxazoles 341 and 342 and their dihydro-derivatives 339 and $\mathbf{3 4 0}$ containing functional groups in high yields. ${ }^{118}$ 


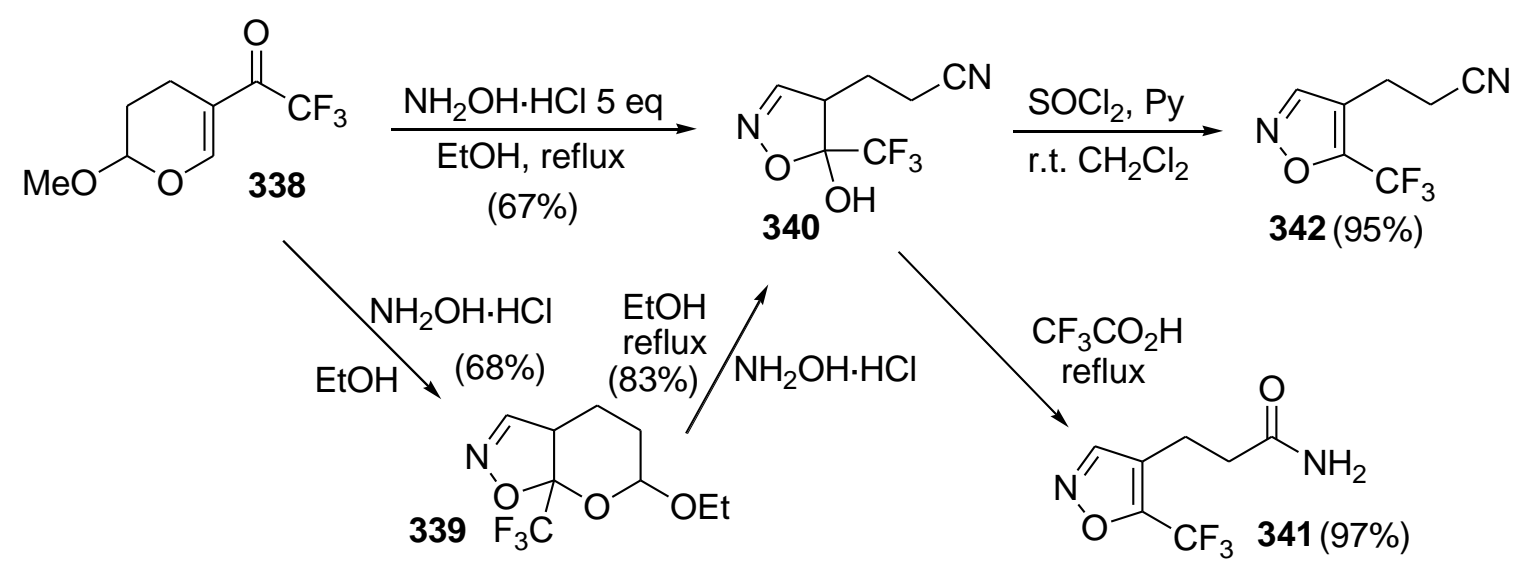

\section{Scheme 97}

Analogously enones 343 were converted into isoxazolines 346, which result from opening of the furan or pyran ring. However, when the reaction is carried out at higher temperatures, it gives rise to tetrahydrofuran and tetrahydropyran derivatives 345, formed apparently upon dehydration of aldehyde oximes $\mathbf{3 4 4}$, resulting from recyclization of the starting enones. The reactions of cyclic enaminoketones 347 with hydroxylamine lead to dihydroisoxazoles 348 containing aminoalkyl side chain as the single diastereomers. Compounds 348 can be dehydrated with sulfuric acid into isoxazoles 349 in high yields. ${ }^{27 b}$

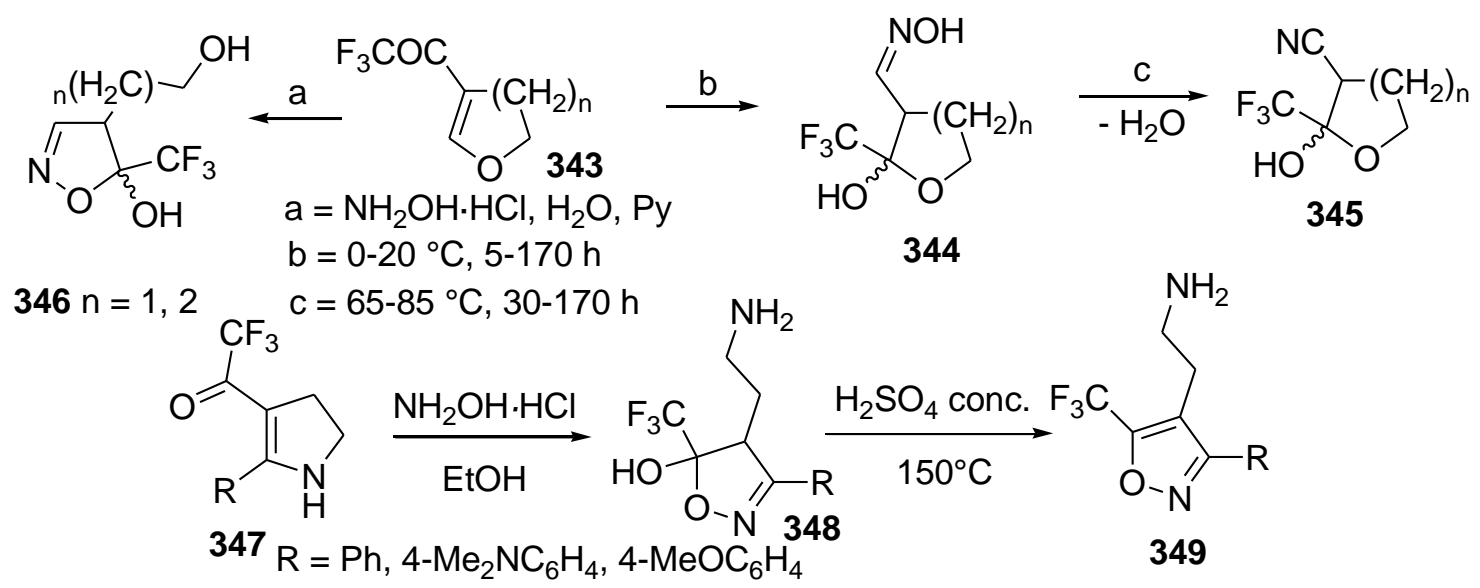

\section{Scheme 98}

The reaction of $\mathbf{3 5 0}$ with N-methylhydroxylamine hydrochloride proceeds as Michael addition forming 351 or the isoxazoles 352 depending on the substituent in 350. ${ }^{119}$

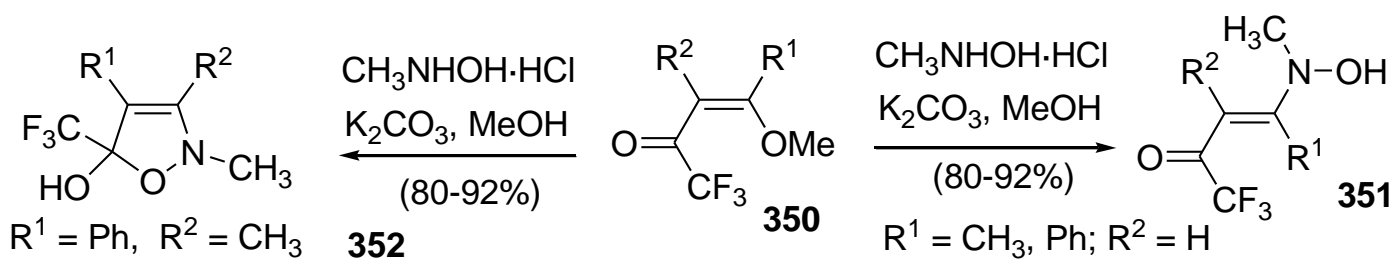

\section{Scheme 99}


The reaction of $\mathbf{3 5 3}$ or $\mathbf{3 5 4}$ with hydroxylamine hydrochloride gave the corresponding ethoxyderivative of isoxazoline $\mathbf{3 5 5}$ or amino-substituted isoxazoles $\mathbf{3 5 6}$ in good yield. ${ }^{99}$

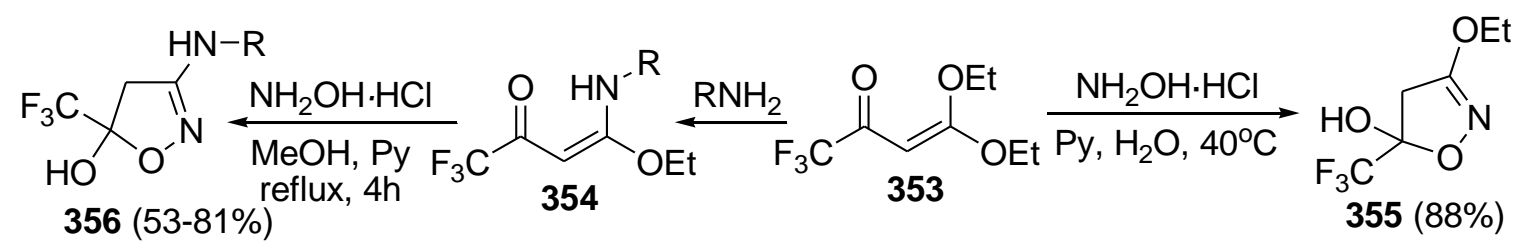

\section{Scheme 100}

In case of 1,3-dipolar cycloaddition of ketone 357 with nitrile oxides both $\mathrm{C}=\mathrm{C}$ and $\mathrm{C}=\mathrm{O}$ participating in the formation of isoxazole rings to afford 1,4,2-dioxazole 359. ${ }^{120}$

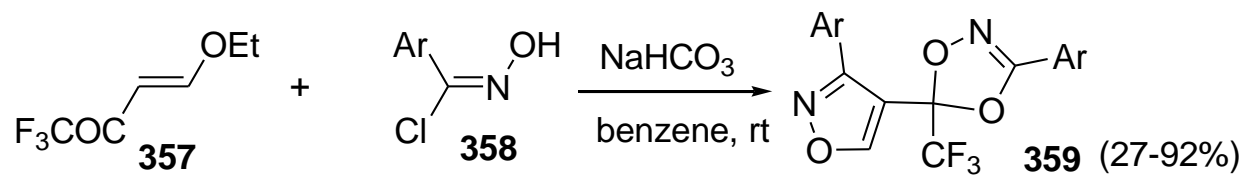

\section{Scheme 101}

[2+3]-Cycloaddition of $\beta$-ethoxy- $\mathrm{CF}_{3}$-enone 357 with $\mathrm{N}$-methyl-C-arylnitrones 360 results in the isoxazolidines 361. These compounds can not be isolated due to transformation to diol $\mathbf{3 6 2}$ and ethanol elimination product 363 under column chromatography purification. ${ }^{121}$

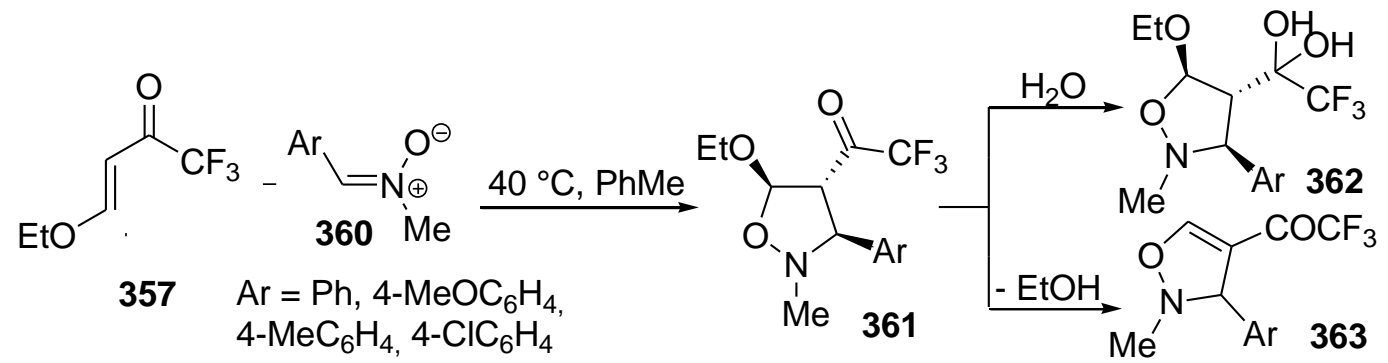

\section{Scheme 102}

Ketones containing no alkoxy-groups in $\beta$-position 364 can also be used for the preparation of isoxazoles 365. Diaryl-substituted isoxazole with unusual regiochemistry 365 was synthesized using the reaction with hydroxylamine with further aromatization by treatment with iodine. ${ }^{121}$

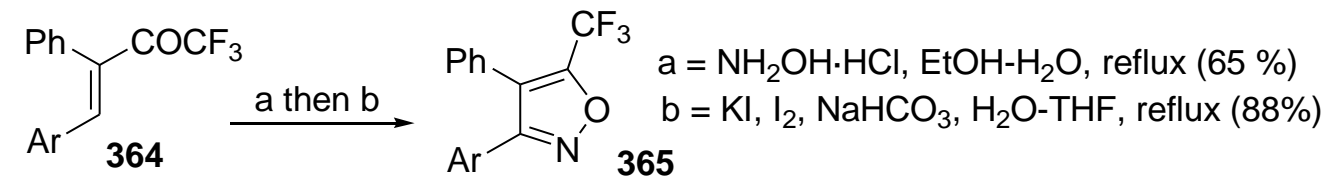

\section{Scheme 103}


The reaction of $\mathbf{3 6 6}$ with hydroxylamine in an acidic medium gives rise to oxime $\mathbf{3 6 7}$, which does not tend to cyclize. The reaction with hydroxylamine in the presence of an equimolar amount of sodium ethoxide gives isoxazolidines $\mathbf{3 6 8}$ in good yields. ${ }^{122}$

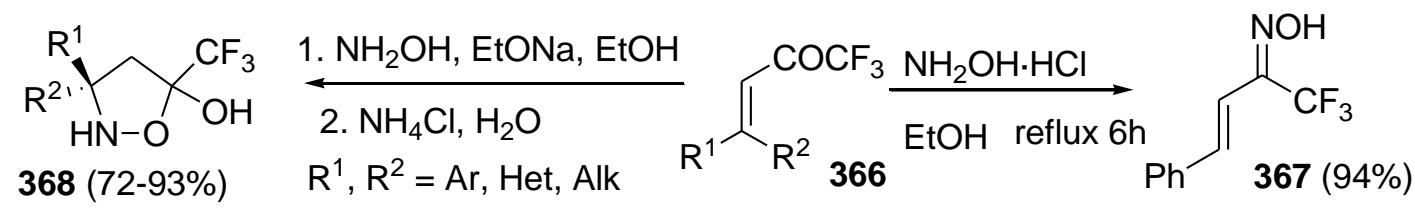

\section{Scheme 104}

Isoxazolines $\mathbf{3 7 2}$ and isoxazoles $\mathbf{3 7 3}$ were also obtained in good yields in the reaction of alkynyl ketones 369 with hydroxylamine. This reaction performed in an acid medium gives oxime 370, which cyclizes to isomeric isoxazole $371 .{ }^{113}$

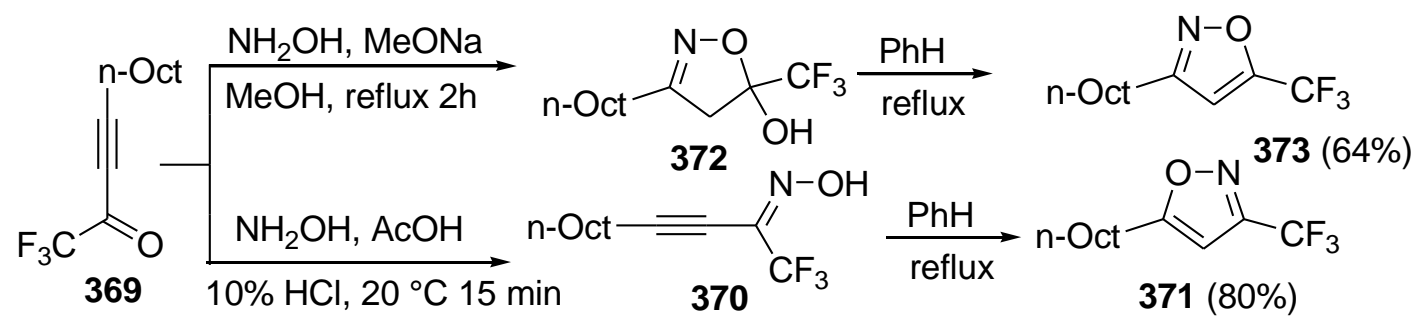

\section{Scheme 105}

Isoselenoazoles 374, otherwise available only with difficulty, can easily be prepared by consecutive treatment of enones $\mathbf{3 7 5}$ with bromine and ammonia. ${ }^{62}$

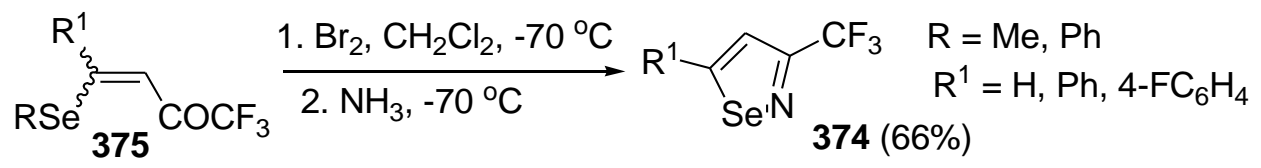

\section{Scheme 106}

3.1.5 Synthesis of oxazoles. The reaction of acetylenic $\mathrm{CF}_{3}$-ketones $\mathbf{3 7 6}$ with methyl isocyanoacetate catalyzed with $\mathrm{AgClO}_{4}$ leads to the formation of the dihydrooxazole 377 in high yields. ${ }^{123}$

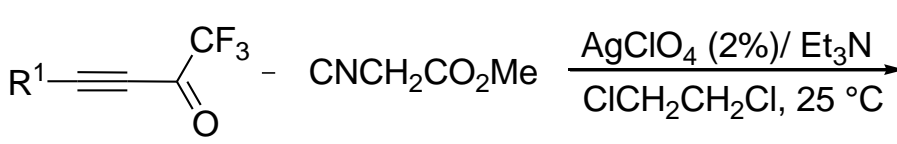

$\left.376 \mathrm{R}^{1}=\mathrm{Ph}, \mathrm{n}-\mathrm{Hex}\right)$

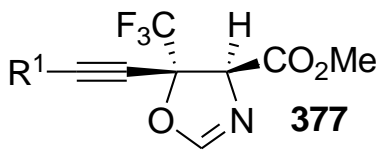

$91-96 \%$

\section{Scheme 107}


4-Oxazolines $\mathbf{3 7 8}$ were obtained by the amination of $\mathbf{3 7 9}$ with nosyloxycarbamates through a domino reaction involving a fast rearrangement of unstable 2-trifluoroacetyl aziridines $\mathbf{3 8 0}{ }^{124}$

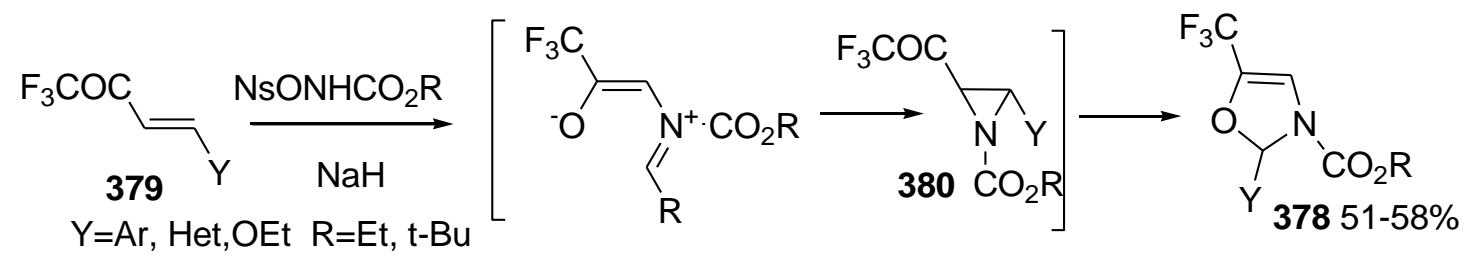

\section{Scheme 108}

3.1.6 Synthesis of triazoles. The reaction of ketone $\mathbf{3 8 1}$ with various azides leads to the formation of the corresponding trifluoroacetyl triazoles $\mathbf{3 8 2}$ hydrated to diols $\mathbf{3 8 3} .{ }^{125}$

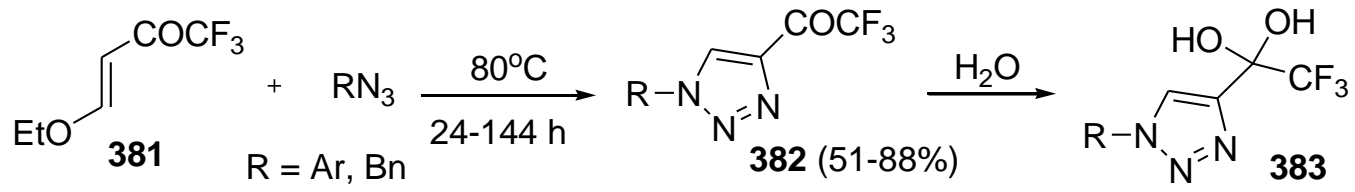

\section{Scheme 109}

\subsection{Synthesis of six-membered heterocycles}

3.2.1 Synthesis of pyridines and their derivatives. Though there are few methods for preparation of $\mathrm{CF}_{3}$-containing pyridines. The synthesis of the $6-\mathrm{CF}_{3}$-nicotinonitrile 384 based on the reaction with $\beta$-dimethylaminoacrylonitrile 385 followed by the treatment of intermediate product 386 with ammonium acetate was proposed. ${ }^{126}$

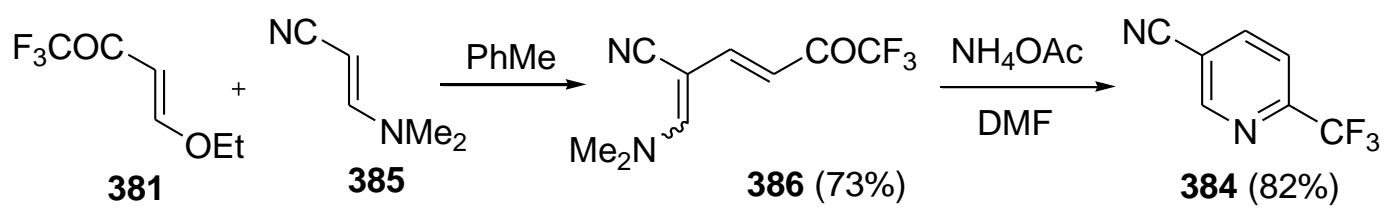

\section{Scheme 110}

The synthesis of 2-arylamino 6- $\mathrm{CF}_{3}$-derivatives of the nicotinonitrile $\mathbf{3 8 7}$ was elaborated using enone 388. The key step of the method is the cyclization of ketone $\mathbf{3 8 8}$ with $\beta$, $\beta$-diaminosubstituted acrylonitrile $\mathbf{3 8 9}$ generated in situ by the reaction of $\mathbf{3 9 0}$ with anilines. ${ }^{127}$

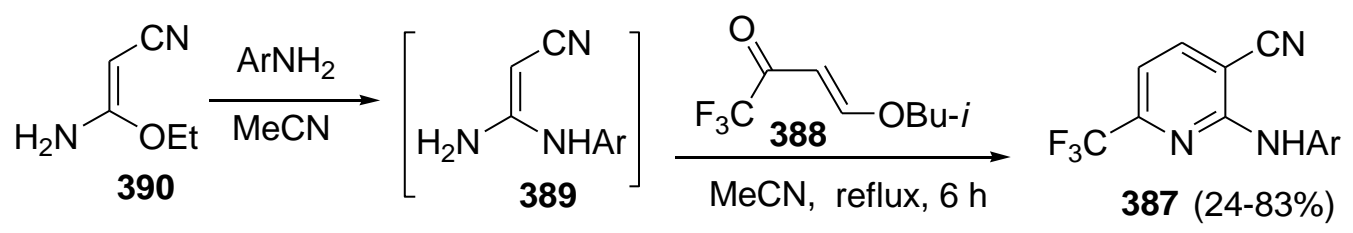

\section{Scheme 111}


The reaction of the enone 391 with $\beta$-aminocrotononitrile results in the formation of 6trifluoromethyldihydropyridine $\mathbf{3 9 2}$ in a low yield; oxidation of this product leads to the corresponding aromatic derivative 393. ${ }^{128}$<smiles>C/C(C#N)=C/N</smiles>

\section{Scheme 112}

The reaction of enone 381 with $\mathrm{N}$-acylacetamidrazones 394 allows to prepare 2-hydrazoderivatives of ethyl 6-trifluoromethylnicotinate $\mathbf{3 9 5}$ in good yields. ${ }^{129}$

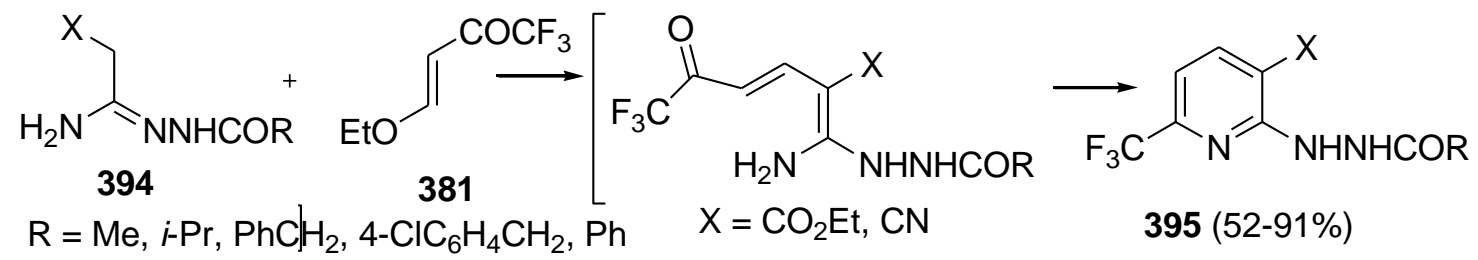

\section{Scheme 113}

Enaminophosphonates containing fluoroalkyl substituents 396 were used for the regioselective preparation of polysubstituted pyridine derivatives 398 by the reaction with fluorinated $\alpha, \beta$ unsaturated ketones 397 at high temperature in the absence of solvent. ${ }^{130}$

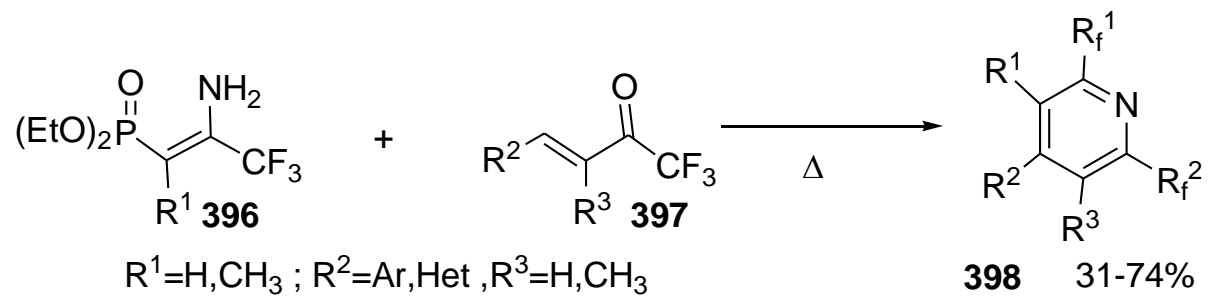

\section{Scheme 114}

New approach for the synthesis of $2-\mathrm{CF}_{3}$ pyridines 399 containing various arylaminosubstituents in the 4-position exploits the reaction of $\mathrm{CF}_{3}$-enone $\mathbf{4 0 0}$ with various aromatic amines including heterocyclic ones. The subsequent reaction of formed enaminoketone 401 with the DMF dimethylacetal leads to dienones $\mathbf{4 0 2}$ which undergo cyclization in high yields to the targeted 2$\mathrm{CF}_{3}$-4-arylaminopyridines 399 with ammonium acetate. Analogous approach is based on the use of 2-aminopyridine derivatives for the synthesis of the 2- $\mathrm{CF}_{3}-4$-pyridylaminopyridines 403 . The same 
method was used for the preparation of $2-\mathrm{CF}_{3}$-pyridine derivatives 404 possessing anticancer activity. ${ }^{131}$

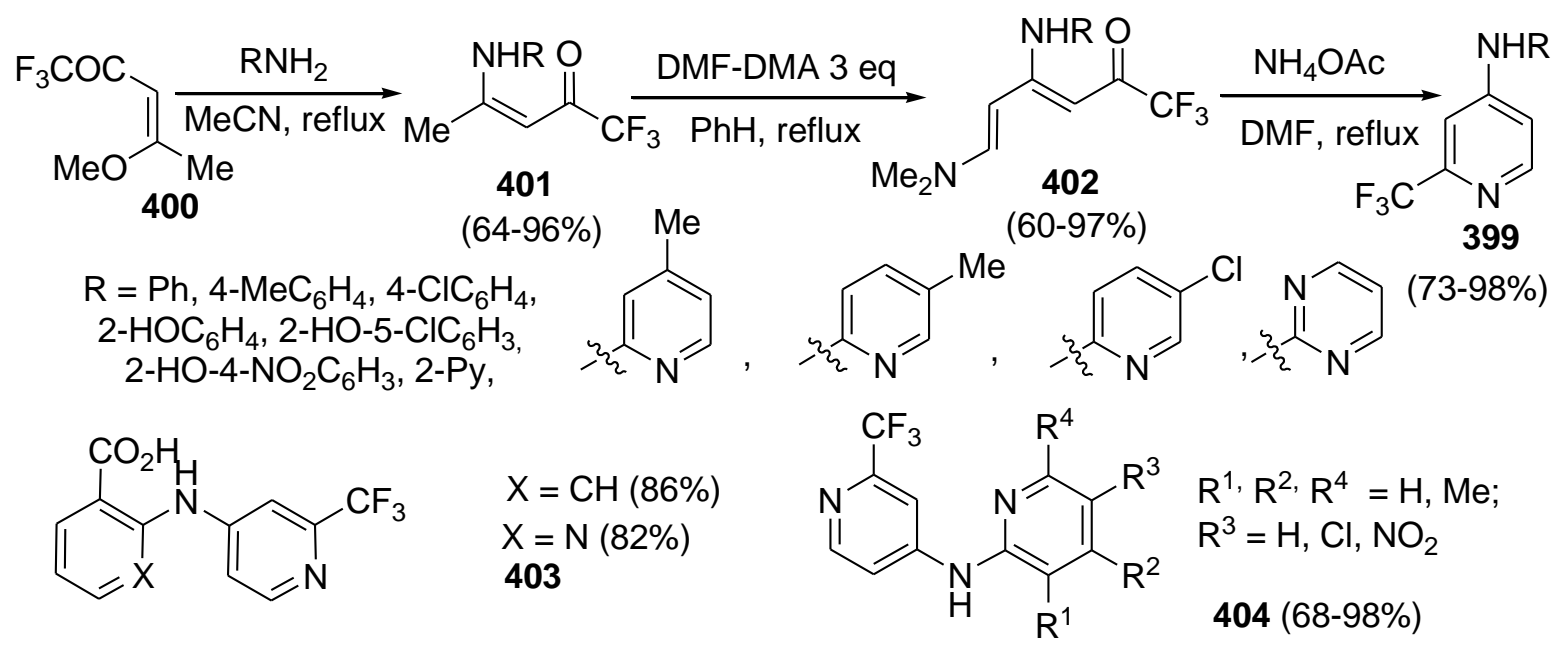

\section{Scheme 115}

$\mathrm{CF}_{3}$-enones $\mathbf{4 0 5}$ react with enamino esters $\mathbf{4 0 6}$ to afford fairly stable hydroxypyridines $\mathbf{4 0 7}$. The hydroxypyridines $\mathbf{4 0 7}$ were dehydrated to form dihydropyridines $\mathbf{4 0 8} .^{132}$

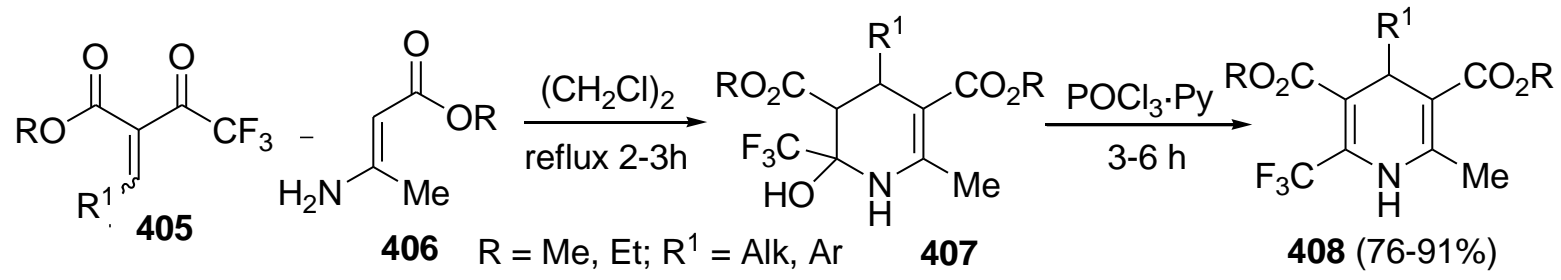

\section{Scheme 116}

The Gantsch type synthesis of the 1,4-dihydropyridines $\mathbf{4 0 9}$ used the reaction of dihydrothiophene-3(2H)-one-1,1-dioxide 410 with $\mathrm{CF}_{3}$-enone 411. The intermediate compound 412 was isolated as the mixture of diastereomers and without further purification utilized in the next step. The target 1,4-dihydropyridine derivative $\mathbf{4 0 9}$ was prepared in good yield. ${ }^{133}$<smiles>O=C(/C=C/Br)C(F)(F)F</smiles><smiles>NC(O)C1CC(=O)CC1=O</smiles><smiles>[Z16]C1=C(S(=O)(=O)[O-])N[C@@](O)(C(F)(F)F)C[C@H]1Br</smiles><smiles>O=S1(=O)CCC2=C1C(Br)C=C(C(C(F)(F)F)C(F)(F)F)N2</smiles>

\section{Scheme 117}


4-Amino-2- $\mathrm{CF}_{3}$-pyridine $\mathbf{4 1 3}$ was prepared in moderate yield using the reaction of ketone 414 with ammonia under heating at high pressure. ${ }^{71 b}$

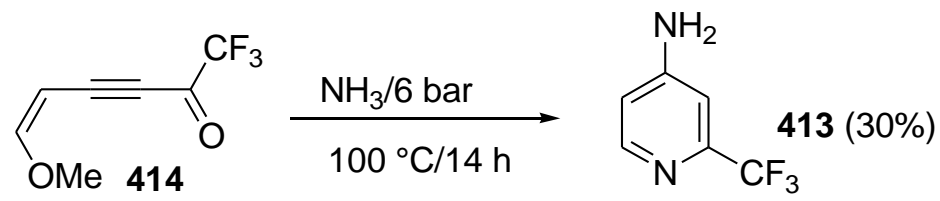

\section{Scheme 118}

Several works are devoted to the methods for the synthesis of the pyridine derivatives using iminates. For instance, ketone $\mathbf{4 1 5}$ was involved in the reaction with iminate $\mathbf{4 1 6}$ prepared from lithiated alkyltrimethylsilanes $\mathbf{4 1 7}$ and aromatic nitriles. The ketone $\mathbf{4 1 9}$ was used for the synthesis of the trifluoromethylpyridine $\mathbf{4 2 0}$ by the reaction with lithiated imine $\mathbf{4 2 1}$. $^{134}$

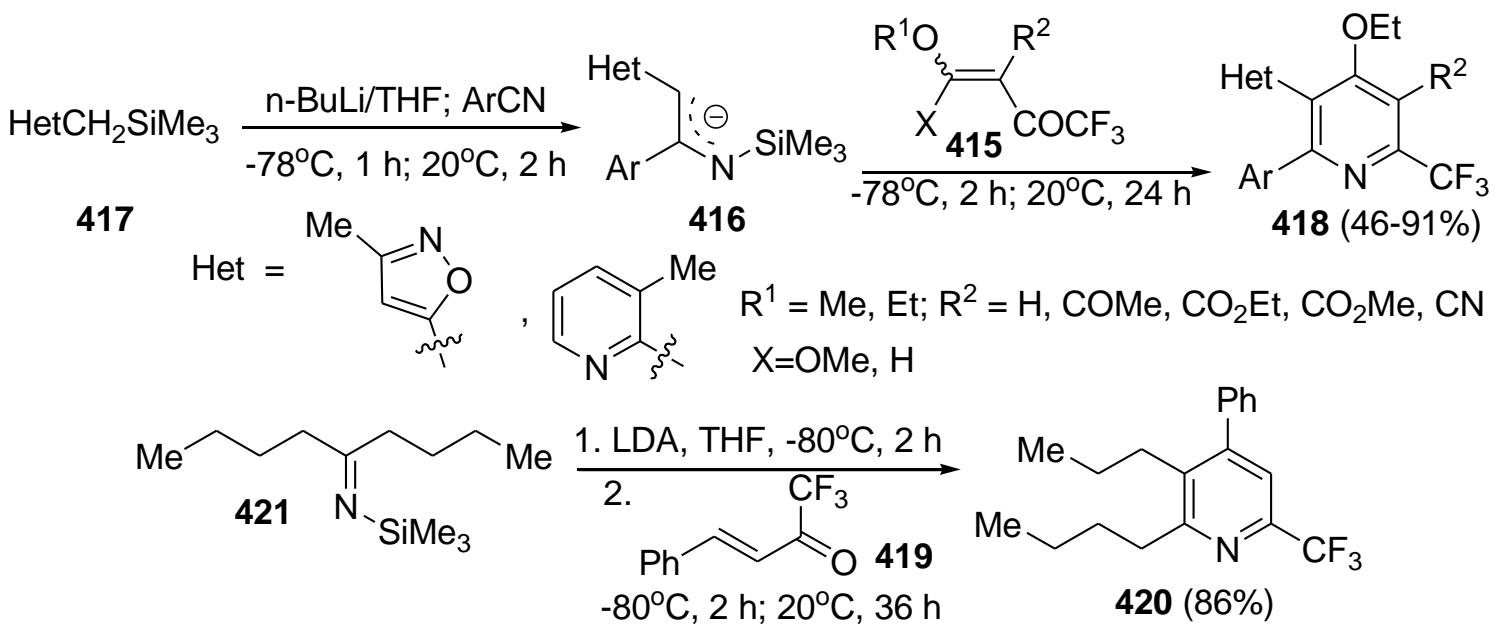

\section{Scheme 119}

Ketone 421a reacts easily with 1,3-diketones and 1,3-ketoesters 423 in the presence of trifluoroacetic acid to give $\alpha$-trifluoromethylpyridines 422a. Similar methods for preparation of pyridines $\mathbf{4 2 2} \mathbf{b}, \mathbf{c}$ involving the reaction of alkoxyenones $\mathbf{4 2 4}$ with $\mathrm{CH}$-acids were described. ${ }^{135}$ 


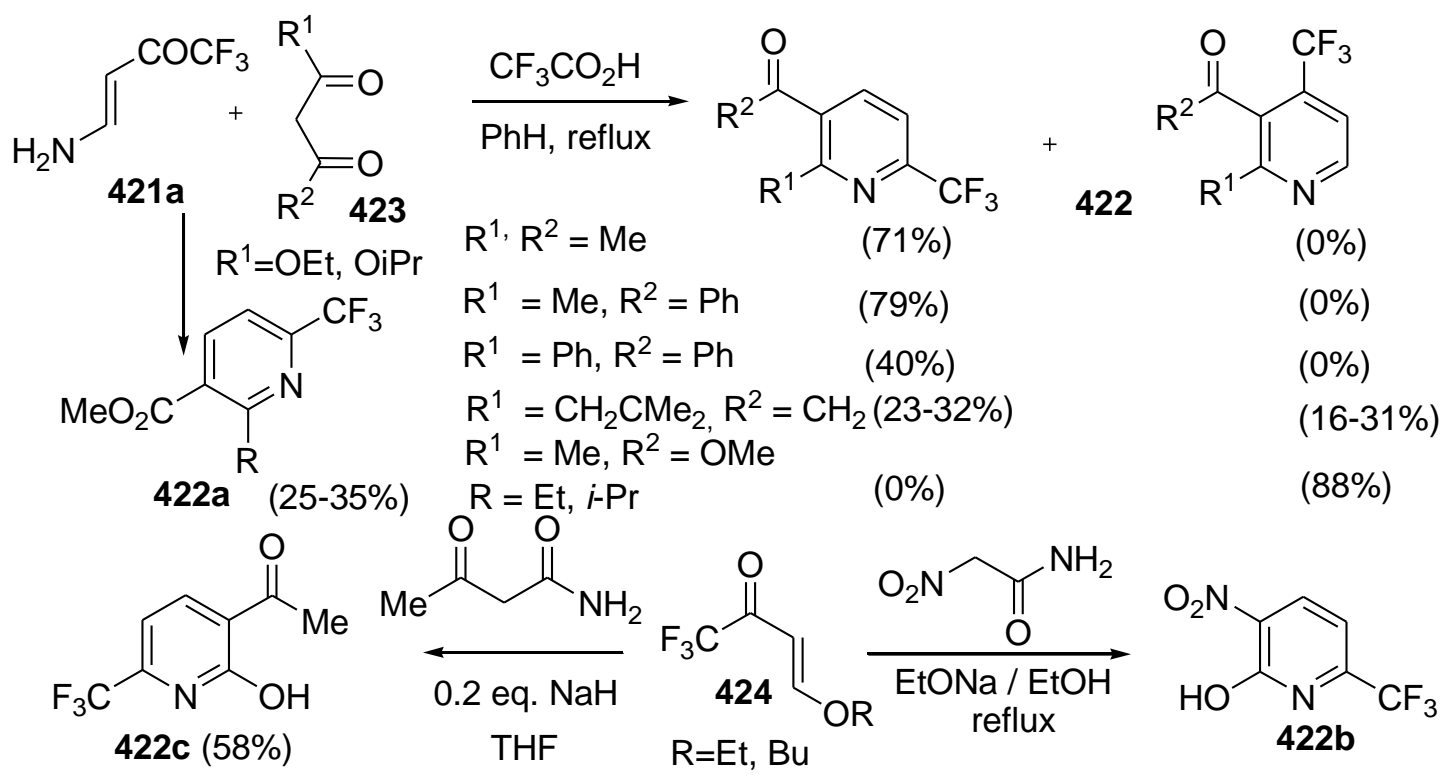

\section{Scheme 120}

2- $\mathrm{CF}_{3}$-pyridine 425 was prepared in very low yield by the reaction of the enamine 426 with ammonium acetate and the ketone $\mathbf{4 2 7}$ by reflux in triglyme. ${ }^{136}$

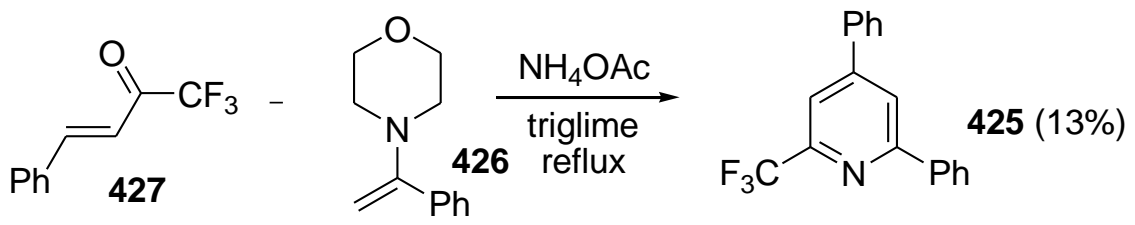

\section{Scheme 121}

The reaction of trifluoromethyl ketones $\mathbf{4 2 8}$ with cyanoacetamide in isopropanol in the presence of calcinated KF leads to stereoselective formation of piperidones $429 \mathbf{a}, \mathbf{b}$ in high yields. Dehydration gives dihydropyridines $430 \mathbf{a}, \mathbf{b}{ }^{137}$

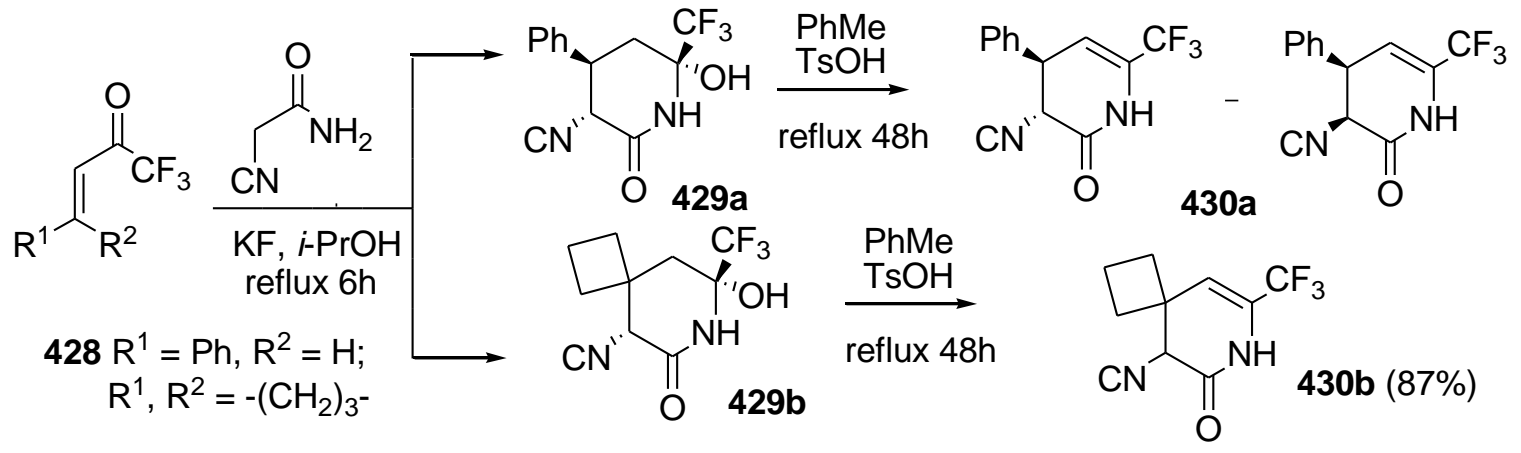

\section{Scheme 122}


The reaction of $\mathrm{CF}_{3}$-enone $\mathbf{4 3 1}$ with cyanothioacetamide depending on conditions permits preparation of the isomeric pyridinethiones 432 and 433 in good yields. The similar method for preparation of pyridine-2-thiols as $\mathrm{N}$-methylmorpholine salts $\mathbf{4 3 5}$ is based on the reaction of enones 434 and cyanothioacetamide in the presence of double excess of N-methylmorpholine. ${ }^{138}$<smiles>Cc1cc(C(F)(F)F)c(C#N)c(=S)[nH]1</smiles>
$433(89 \%) \quad R$<smiles>N#CCC(N)=S</smiles><smiles>CCO/C=C(/C=O)C(=O)C(C)(C)C</smiles><smiles>COC(=CC(=O)C(F)(F)F)C(C)(C)C</smiles>
431

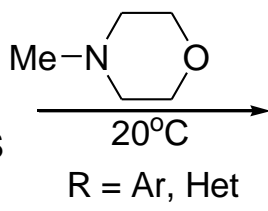<smiles>CCOC(=O)C(F)(F)c1cc(C)c(C#N)c(=S)[nH]1</smiles>

432 (94\%)<smiles>[R]C(=O)c1cc(C#N)c(S(=O)(=O)[Sb])nc1C(F)(F)F</smiles>

\section{Scheme 123}

A novel method for the preparation of $\mathrm{CF}_{3}$ - pyridines 436 was elaborated recently. First step is the synthesis of $\alpha$-hydroxydihydropyrans 437 by reaction of 438 and $\alpha$-cyanoacetophenones 439 . Second step is transformation of $\mathbf{4 3 7}$ with ammonium acetate to form tetrahydropyridines $\mathbf{4 4 0}$. Third is the dehydration of $\mathbf{4 4 0}$ to give dihydropyridines $\mathbf{4 4 1}$. The final stage is oxidation into the target pyridines $\mathbf{4 3 6}$ with DDQ. All compounds were prepared in good yields. ${ }^{139}$

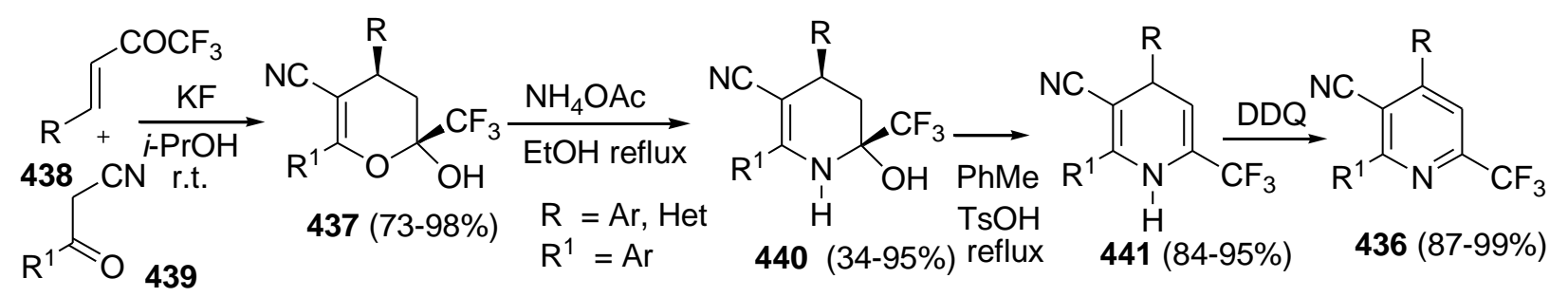

\section{Scheme 124}

It has been found that chloroacetonitrile reacts with $\mathbf{4 4 2}$ in the presence of zinc and trimethylchlorosilane to produce the $\beta$-trimethylsilyloxynitrile 443 and the elimination product 444 . 4-Trifluoromethyl-2-pyridone $\mathbf{4 4 5}$ was prepared in good yield after reflux of $\mathbf{4 4 3}$ and $\mathbf{4 4 4}$ mixture in concentrated $\mathrm{HCl}$. Chlorination of $\mathbf{4 4 5}$ with $\mathrm{POCl}_{3}$ gave $\mathbf{4 4 6} .{ }^{140}$

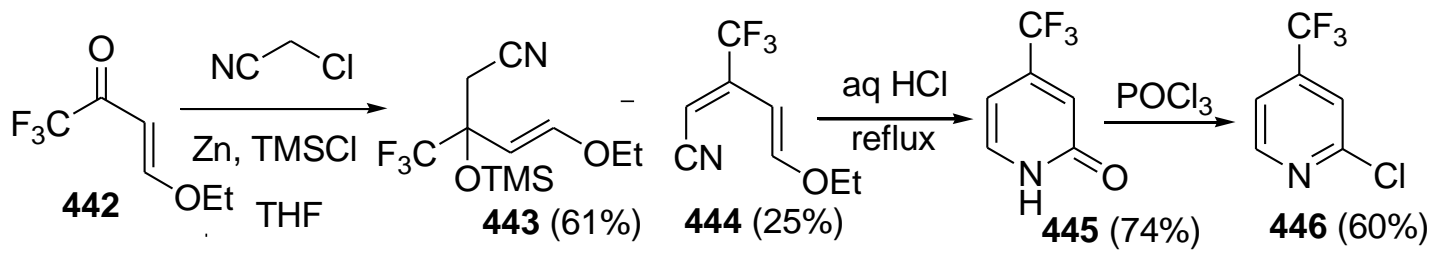

\section{Scheme 125}


Treatment of enones 447 with eight equivalents of magnesium and chlorotrimethylsilane in DMF leads to difluoro-derivative of Danishefsky-diene 448. Hardly available 5,5-difluoroderivatives of dihydropyridone-4 450 were obtained using aldimines 449 as dienophiles. ${ }^{141}$<smiles>[R6]O/C=C/C(=O)C(F)(F)F</smiles>

\section{Scheme 126}

A chemoselective synthesis of alkoxy or alkylamino substituted tetrahydropyridines bearing trifluoroacetyl group 451a,b was elaborated by reaction of primary amines with ketone $\mathbf{4 5 2} .{ }^{142}$

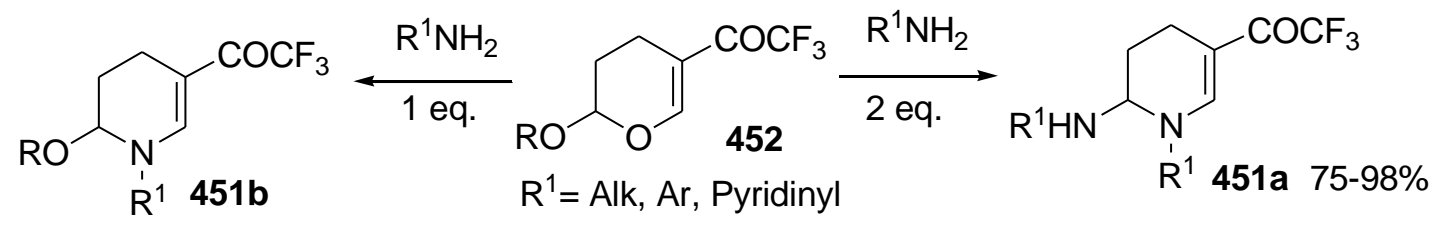

\section{Scheme 127}

3.2.2 Synthesis of quinolines and benzoquinolines. $\beta$-Arylamino-substituted enones $\mathbf{4 5 3}$ were cyclized to 2-trifluoromethyl- 454 and $4-\mathrm{CF}_{3}$-quinolines 455 under treatment with acids. ${ }^{113} \mathrm{POCl}_{3}$, $\mathrm{ZnCl}_{2}$ and PPA were used as catalysts. ${ }^{143}$<smiles>[R]/C(=C/C(=O)OC(F)(F)F)Nc1[R]cccc1</smiles><smiles>[R7]c1cc(C(F)(F)F)nc2c1C=C[R1](C(C)(C)C)C=C2</smiles>

454 $\mathrm{R}^{1}=\mathrm{Me}, \mathrm{OMe}, \mathrm{Hal} ; \mathrm{R}^{2}=\mathrm{H}, \mathrm{Alk}, \mathrm{Ph}$<smiles>[R]c1cc(C(F)(F)F)c2ccc[Y7]c2n1</smiles>

455

\section{Scheme 128}

Quinolines $\mathbf{4 5 5}$ are the products of "normal" cyclization, while the mechanism of formation of 2-trifluoromethylquinolines $\mathbf{4 5 4}$ is the question of further investigations. The ratio of the products depends on the nature of acidic catalyst applied and the structure of the enone. Cyclization of enones with $\mathrm{R}^{2}=\mathrm{H}$ gives only 2-trifluoromethylquinolines 454 . When $\mathrm{R}^{2}=\mathrm{Alk}$ or $\mathrm{Ph}$, 4trifluoromethylquinolines $\mathbf{4 5 5}$ are formed predominantly. ${ }^{144}$ 
Various enaminoketones $456 \mathbf{a}$ were used for preparation of benzo[ $h]$ quinolines 457a. The target heterocycles $\mathbf{4 5 7}$ were obtained in good yields using TFA as cyclizing agent. The alkoxyketones 456b can be used for the synthesis of isomeric 4-CF3-benzo[h]quinolines 457b. The enaminoketones $\mathbf{4 5 6}$ prepared from 1-naphthylamine were cyclized with PPA. ${ }^{145}$

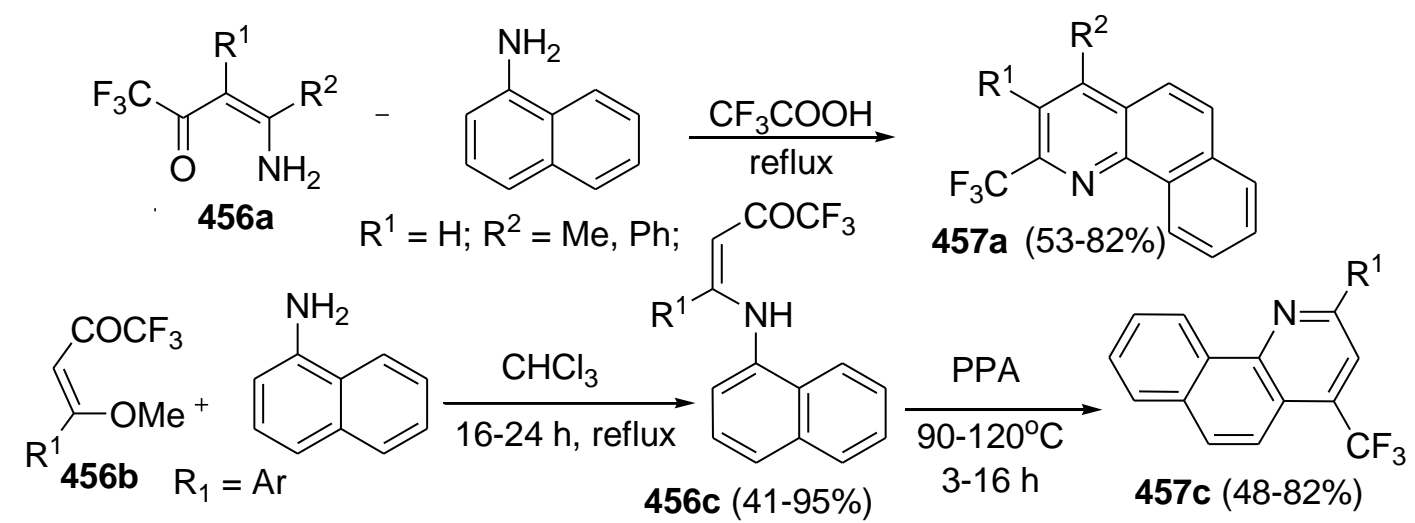

\section{Scheme 129}

The enaminodione $\mathbf{4 5 8}$ reacts with aromatic amines in the presence of catalytic amounts of $\mathrm{FeCl}_{3}$ to give $\mathrm{N}$-aryl-substituted enaminodiones 459 , which cyclize on treatment with PPA or $\mathrm{TiCl}_{4}$, the yields of the reaction products $\mathbf{4 6 0}$ being substantially higher in the case of $\mathrm{TiCl}_{4}$.

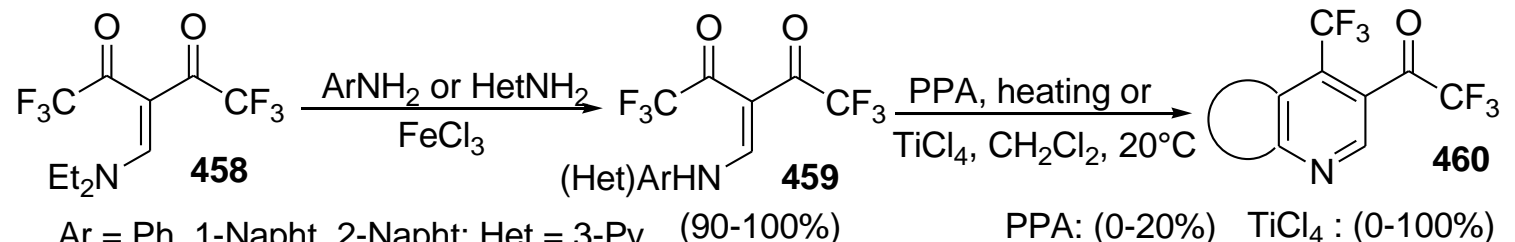

\section{Scheme 130}

The synthesis of $\mathrm{CF}_{3}$-derivatives of dihydrobenzo[c]acridine $\mathbf{4 6 1}$ is based on the application of $\mathrm{CF}_{3}$-enone $\mathbf{4 6 2}$ obtained from tetralone-1. ${ }^{146}$ In the reaction of $\mathbf{4 6 2}$ with various substituted anilines the formation of enaminoketones 463 is observed. Compounds 463 are cyclized to the target dihydrobenzo[ $c$ ]acridines $\mathbf{4 6 1}$ in high yields by treatment with polyphosphoric acid.

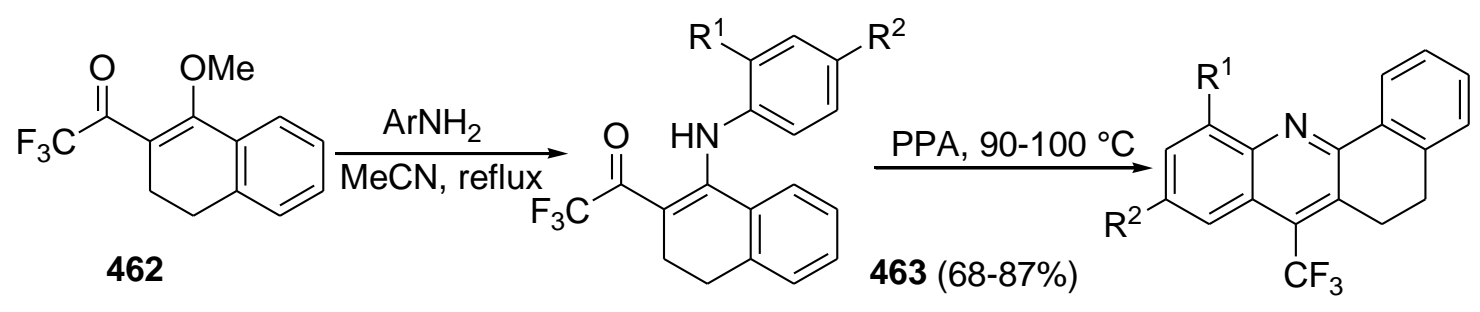

$\mathrm{R}^{1}, \mathrm{R}^{2}=\mathrm{H}, \mathrm{H} ; \mathrm{H}, \mathrm{Me} ; \mathrm{Me}, \mathrm{H} ; \mathrm{H}, \mathrm{Br} ; \mathrm{Br}, \mathrm{H} ; \mathrm{H}, \mathrm{Cl} ; \mathrm{H}, \mathrm{F} ; \mathrm{H}, \mathrm{MeO} ; \mathrm{OH}, \mathrm{H} 461$ (44-82\%)

\section{Scheme 131}


A simple and general one-pot synthesis of 2-trifluoromethylquinolines 464 from anilines and enaminoketone $\mathbf{4 6 5}$ was elaborated. Treatment of $\mathbf{4 6 5}$ with triflic anhydride caused the formation of 3-trifloxy-3-trifluoromethylpropeniminium triflate $\mathbf{4 6 6}$ which was found to react with electron-rich aromatics to give corresponding $\mathrm{CF}_{3}$-quinolines 464 in excellent yields. ${ }^{147}$

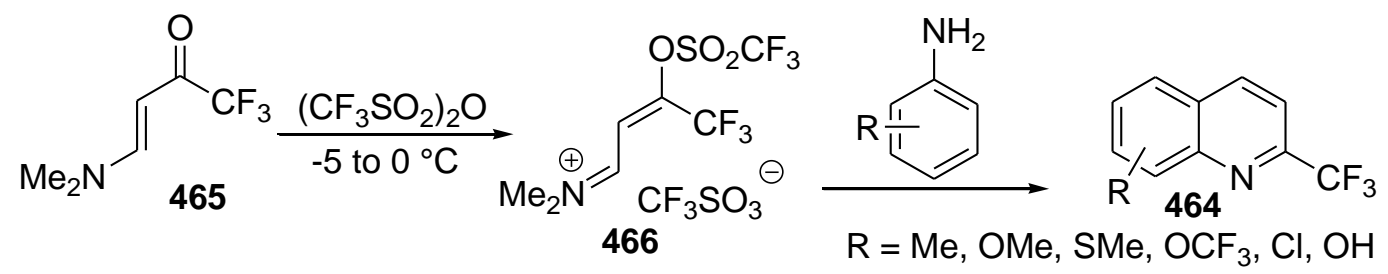

\section{Scheme 132}

The effective method for preparation of 2-substituted 4-quinolinecarbaldehydes 467 is based on the reaction of acetylenic ketones $\mathbf{4 6 8}$ with 2-aminothiophenol. The reaction proceeds through formation of diacetal $\mathbf{4 6 9}$ which is hydrolyzed with formic acid. ${ }^{148}$

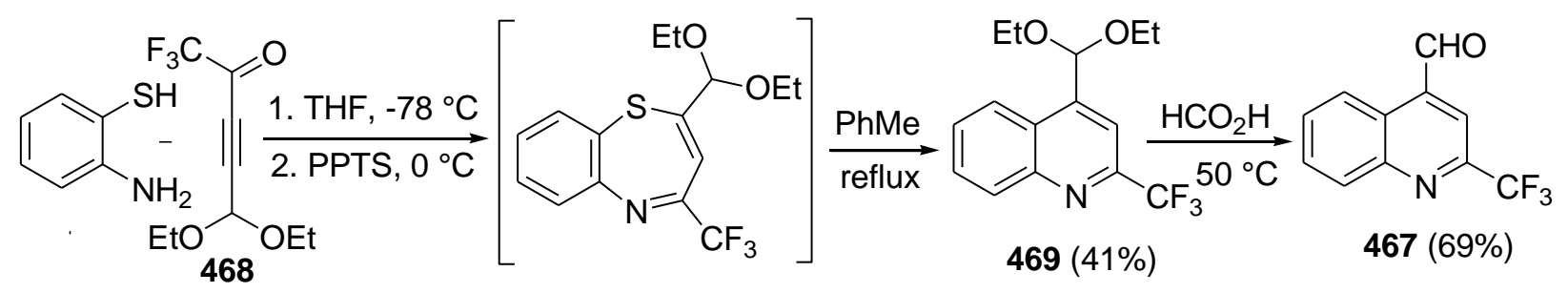

\section{Scheme 133}

Imino-derivatives of $\mathbf{4 7 0}$ can be also applied for the synthesis of quinolines derivative $\mathbf{4 7 1}$ in good yield under dehydrogenation $(\mathrm{Pd} / \mathrm{C}){ }^{28}$

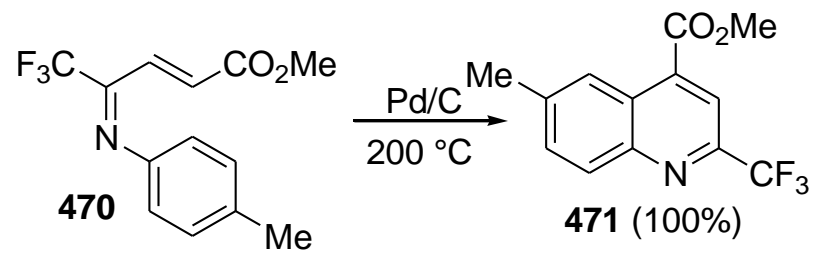

\section{Scheme 134}

3.2.3 Synthesis of pyrans, thiopyrans and their derivatives. Diels-Alder reaction of difluorinated Danishefsky-diene $\mathbf{4 7 2}$ with various aldehydes was studied. The corresponding pyran-4-ones $\mathbf{4 7 3}$ were obtained in moderate yields. The asymmetric synthesis of dihydropyrone 474 using Ti(IV)$(R)$-BINOL catalyst was demonstrated. ${ }^{141}$ 
$\overbrace{\mathrm{Ph}}^{\mathrm{F}_{\mathrm{F}}^{\mathrm{F}}} \frac{\mathrm{PhCHO}, \mathrm{Ti}(\mathrm{O}-i-\mathrm{Pr})_{4} / \mathrm{CH}_{2} \mathrm{Cl}_{2}}{(R)-\mathrm{BINOL}}$

$474(40 \%, 92 \%$ ee $)$<smiles>CCOC=CC(OC)=C(F)F</smiles><smiles>[R]C1OC=CC(=O)C1(F)F</smiles>

473 (50-64\%)

\section{Scheme 135}

An attempt to prepare unsubstituted $\mathrm{CF}_{3}$-enone $\mathbf{4 7 5}$ from ethyl trifluoroacetoacetate have been unsuccessful due to spontaneous dimerization of $\mathbf{4 7 5}$ to give dihydropyran $\mathbf{4 7 6} .{ }^{149}$

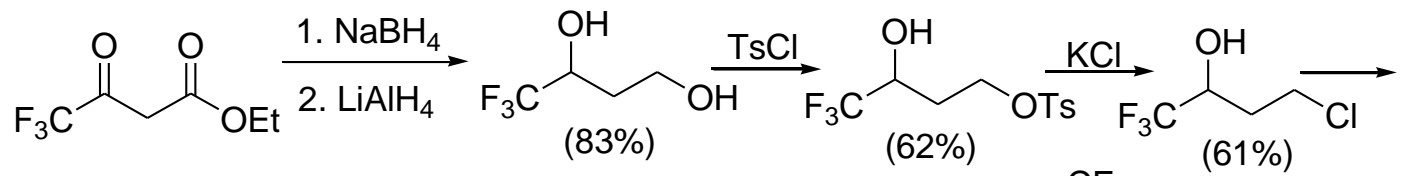

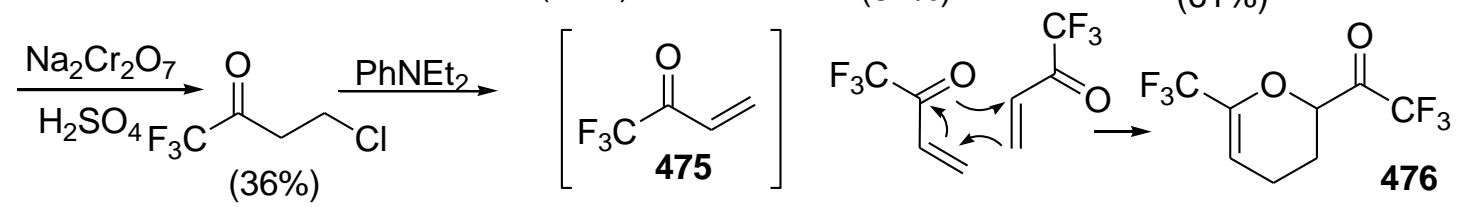

\section{Scheme 136}

The reactions of trifluoromethyl enones $\mathbf{4 7 7}$ with malonodinitrile in the presence of pyrrolidine as a catalyst gave the corresponding pyrans $\mathbf{4 7 8} .{ }^{137}$

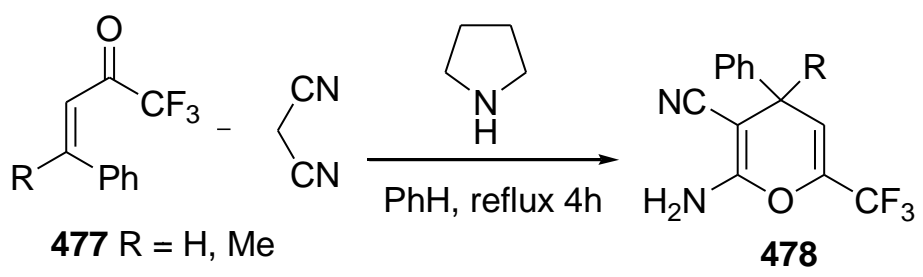

\section{Scheme 137}

The ketone and diol form of compounds $\mathbf{4 7 9}$ can be used as heterodiene in the Diels-Alder reaction to reveal the stereoselective approach for dihydropyrans $\mathbf{4 8 0} .{ }^{149}$

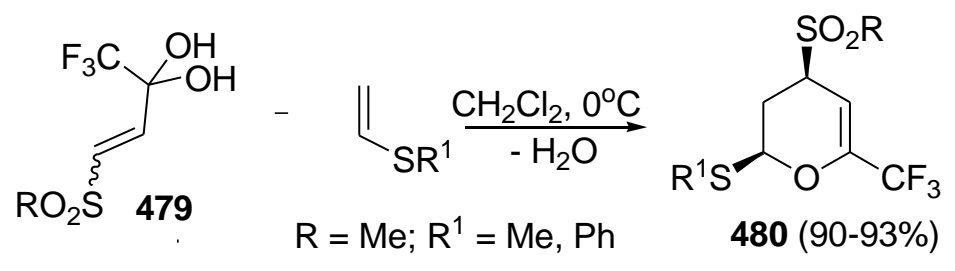

\section{Scheme 138}


The cycloaddition of $\alpha, \beta$-unsaturated aldehydes $\mathbf{4 8 1}$ with $\mathbf{4 8 2}$ leads to unexpected cycloadducts $\mathbf{4 8 3}$ having alkoxy-group migrated as a mixture of cis-/trans-isomers. $^{121}$

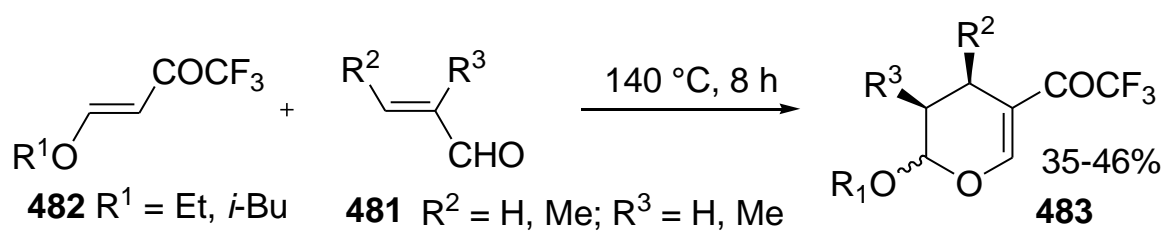

\section{Scheme 139}

The inverse-electron-demand hetero-Diels-Alder reaction of $\mathbf{4 8 4}$ occurred under mild conditions using a chiral diphenylprolinol silyl ether as the catalyst. The corresponding trifluoromethyl-dihydropyan-2-ones $\mathbf{4 8 5}$ were obtained with high ee and transformed to $\mathbf{4 8 6}$. $^{150}$

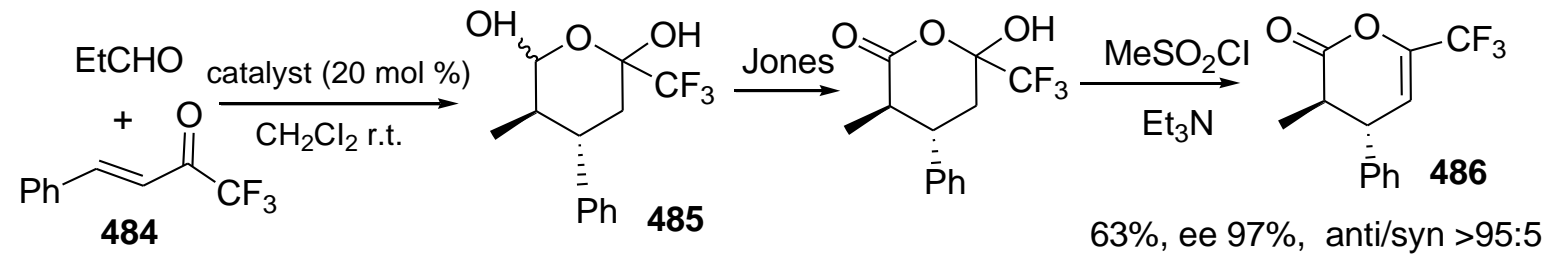

\section{Scheme 140}

The influence of various Lewis acids on the cycloaddition reaction of $\beta$-alkoxy $\mathrm{CF}_{3}$-enones 487 with vinyl ethers $\mathbf{4 8 8}$ was investigated. The highest ratio of diastereoisomers was obtained using $\mathrm{TiCl}_{4}$. The preparation of chiral $\mathrm{CF}_{3}$-dihydropyrans 491 was also investigated. In this case the reaction of $\mathrm{CF}_{3}$-enone 490 containing chiral substituent in $\beta$-position was used. The application of $\mathrm{TiCl}_{4}$ gave the target pyrans $\mathbf{4 9 1}$ in high yields but de is very low. ${ }^{151}$
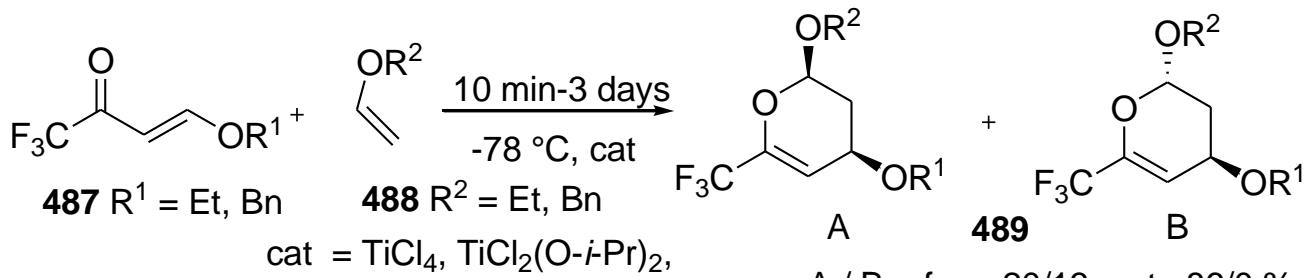

$\mathrm{AlCl}_{3}, \mathrm{EtAlCl}_{2}, \mathrm{Et}_{2} \mathrm{AlCl}, \mathrm{ZnCl}_{2}$

$A / B=$ from $20 / 13$ up to $86 / 0 \%$<smiles>C[C@@H]([PH2+])O/C=C/C(=O)C(F)(F)F</smiles>

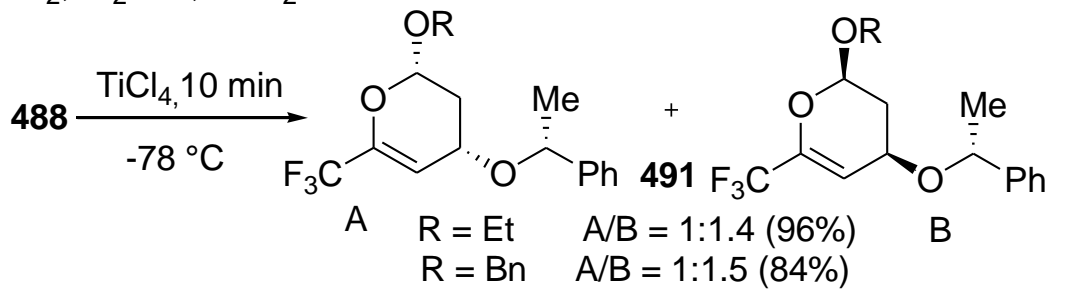

\section{Scheme 141}


Cycloaddition proceeds especially easily for $\mathbf{4 9 2}$ due to the presence of the second strong EWG increasing the reactivity of trifluoromethylenones 492 as heterodienes.

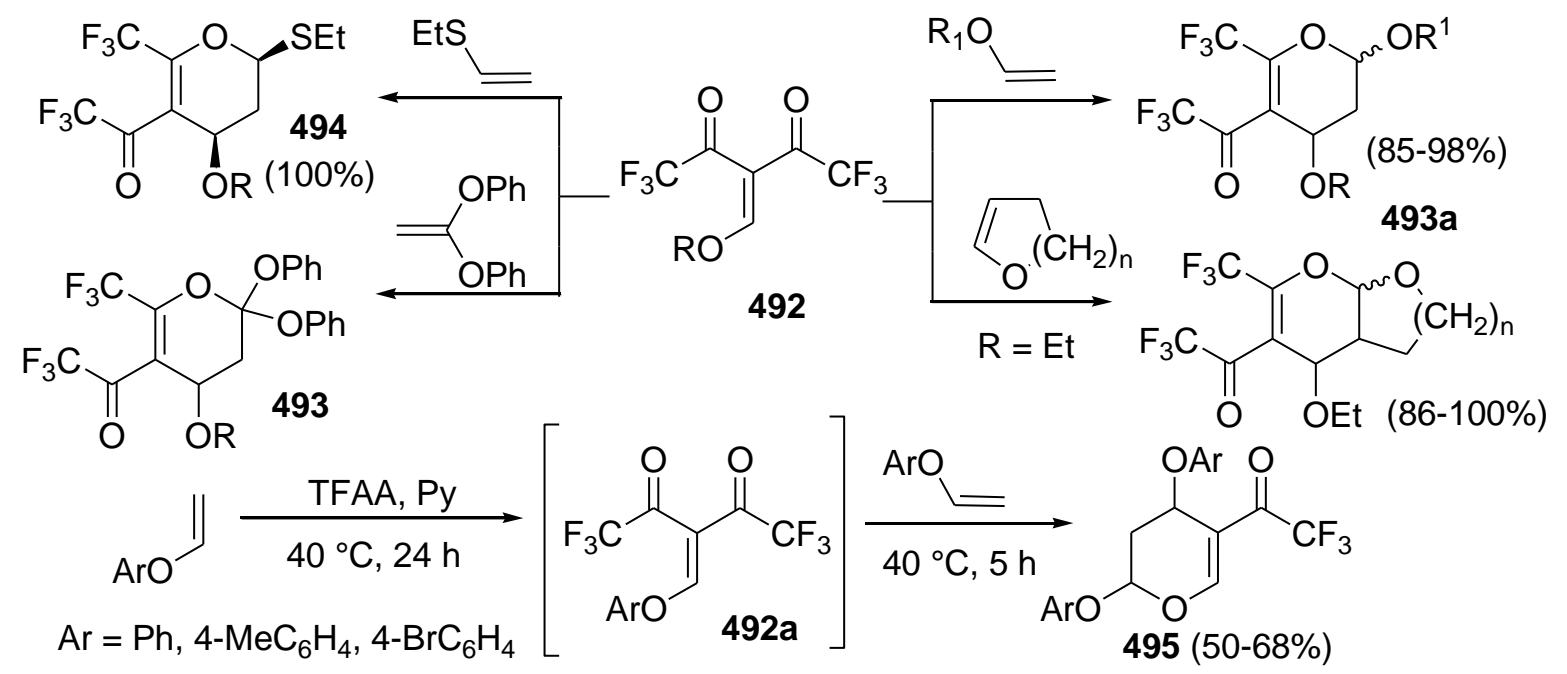

\section{Scheme 142}

The reaction is carried out at room temperature to give 493 in high yields. Thioethers reacted similarly to give single diastereomers of pyranes 494. Aryl vinyl ethers react with trifluoroacetic anhydride to give the corresponding bis(trifluoroacetyl) derivatives 492a. It was found that these compounds are unstable. However, they can be introduced without isolation in the reaction with a second equivalent of aryl vinyl ether to form $\mathbf{4 9 5}$ in good yields. ${ }^{152}$

The solid-phase methodology can be successfully applied to the cycloaddition of $\beta$-benzyloxy$\mathrm{CF}_{3}$-enone 496 and vinyl ether 497. The reaction is catalyzed with europium(III) complex and proceeds in moderate yield though with high stereoselectivity. The target pyran 498 was obtained after the treatment 499 with $\mathrm{LiBHEt}_{3}$. The reaction of $\mathbf{4 9 6 a}$ with vinyl ethers affords 3,4-dihydro2H-pyrans 500 and $\mathbf{5 0 1}$ in good yields. ${ }^{153}$

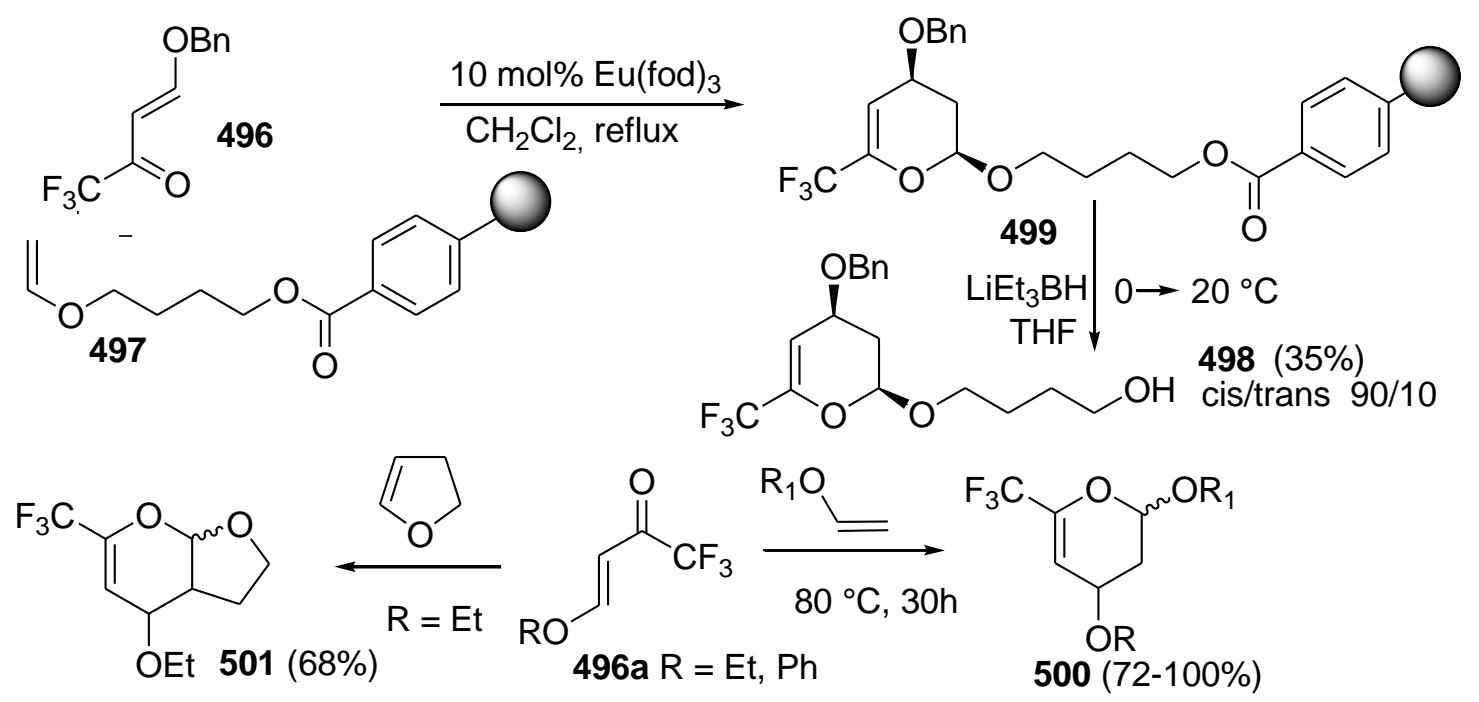

\section{Scheme 143}


A new multistep synthesis of tri- and difluoromevalonates 502 starting from $\mathbf{5 0 3}$ has been developed. Enantiomers of fluoromevalonates can be obtained by chromatography separation. ${ }^{154}$

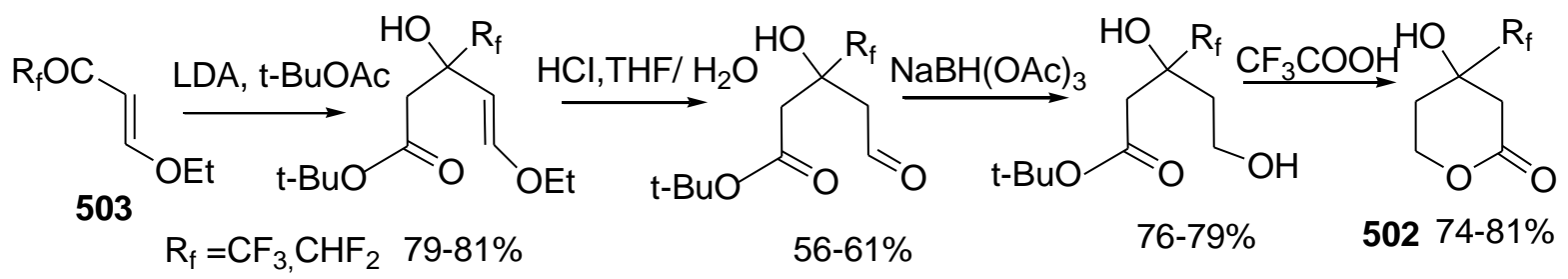

\section{Scheme 144}

Cyano substituted dihydropyrans $\mathbf{5 0 4}$ were obtained in the reaction of $\mathbf{5 0 5}$ with $\alpha$-cyanoketones. The reaction proceeds in the presence of calcinated KF $100 \%$ stereoselectively. ${ }^{155}$

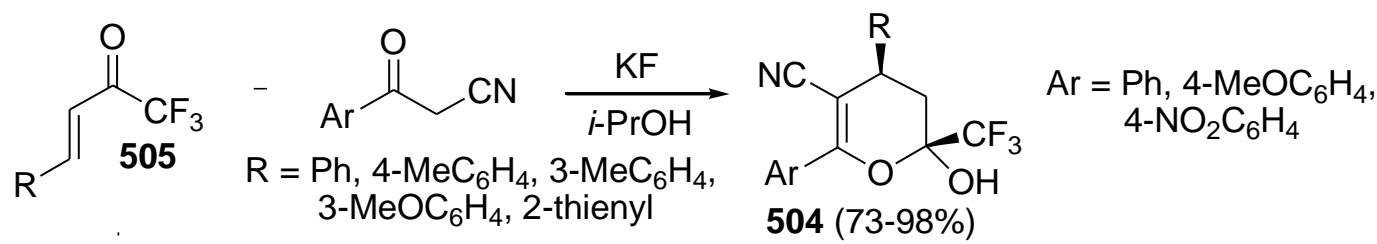

\section{Scheme 145}

Pyran derivatives $\mathbf{5 0 7}$ were obtained as the single diastereomer in the reaction of trifluoroacetylstyrene with 4-methylthiophenol. The second reaction product was Michael adduct 506. Depending on the reaction conditions each of the two products can be obtained selectively. ${ }^{156}$

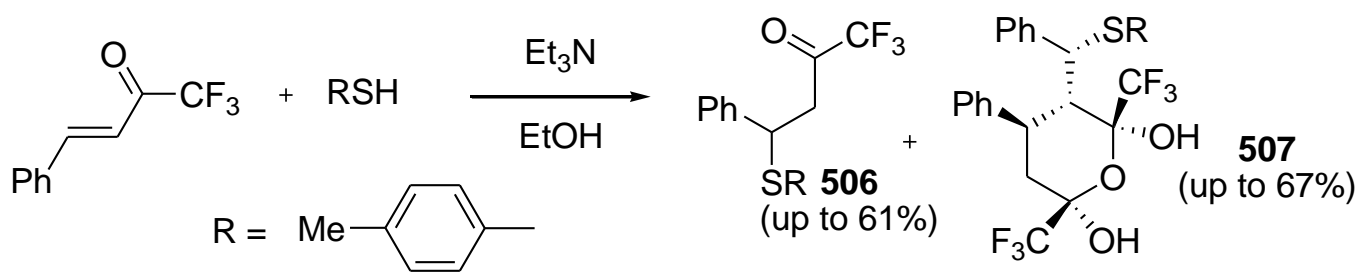

\section{Scheme 146}

The reaction of trifluoromethyl enones with ammonium hydrosulfide depends on the structure of the initial enone. For instance, trifluoroacetylstyrene reacts stereospecifically yielding tetrahydrothiapyran $\mathbf{5 0 8}$ as one diastereoisomer. The reaction with cyclobutylsubstituted enone $\mathbf{5 0 9}$ affords a mixture of cis- and trans-diastereomers 510a,b in 1:1 ratio. ${ }^{157}$ 


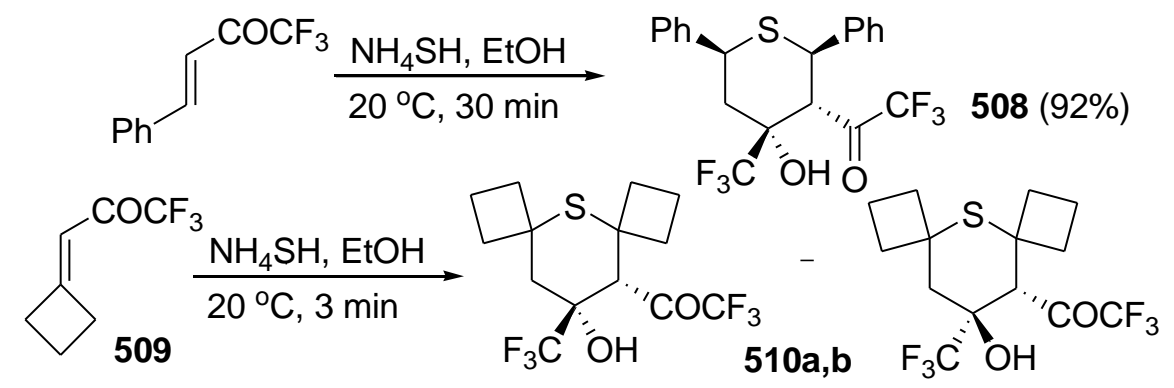

\section{Scheme 147}

The reaction of $\mathbf{5 1 1}$ with 2-mercaptobenzaldehyde leads to thiochromanes $\mathbf{5 1 2}$ which can be easily transformed into $2 \mathrm{H}$-thiochromenes 513 by heating. The intermediate thiochromane 512 were isolated only in case of $\mathrm{CF}_{3}$-enone having the phenyl substituent. ${ }^{156}$

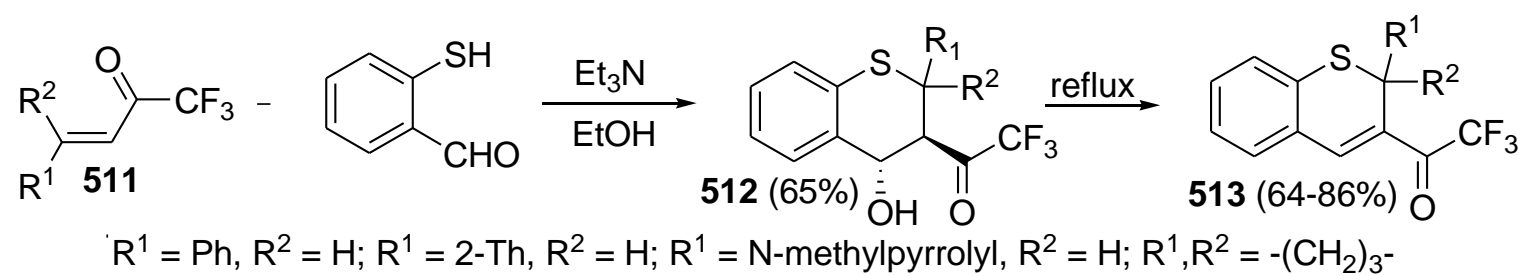

\section{Scheme 148}

The reaction of 2-aminothiopenol with cyclic $\beta$-alkoxyenones 514 leads to formation of benzothiazolines $\mathbf{5 1 5}$ binding with tetrahydrofuran and tetrahydropyran ring. ${ }^{158}$

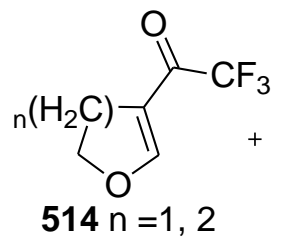<smiles>COc1ccc(N)c(S)c1</smiles>

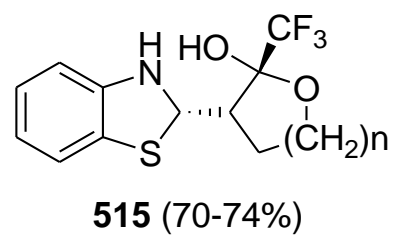

\section{Scheme 149}

Spiro-pyrane derivative $\mathbf{5 1 8}$ were obtained in good yields in the reaction of trimethylsilyl ethers 516 with $\beta$-ethoxy ketone $\mathbf{5 1 7}$ catalyzed by boron trifluoride-diethyl ether complex. ${ }^{159}$

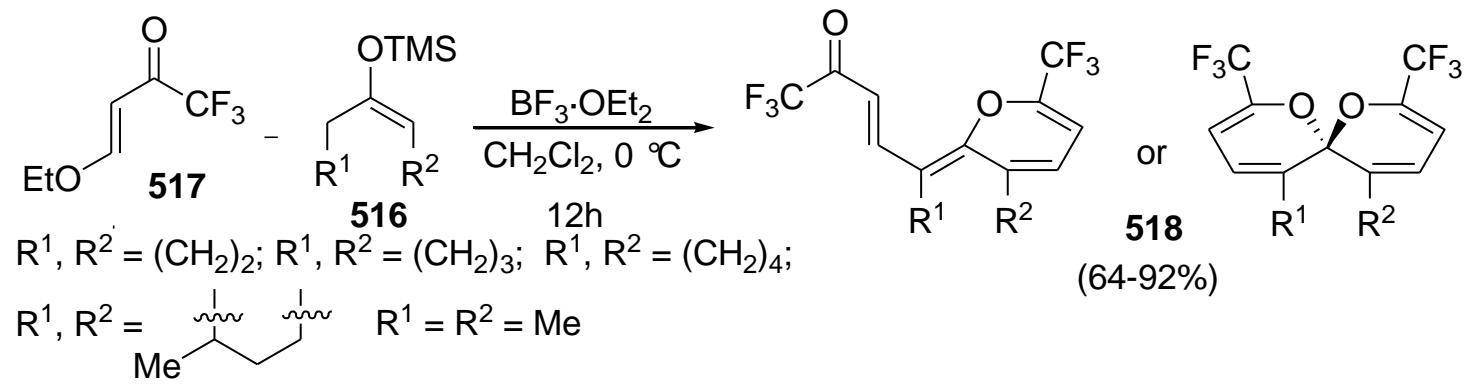

\section{Scheme 150}


The Knoevenagel condensation of ethyl trifluoroacetoacetate with salicylaldehydes provides a simple and convenient approach to substituted (trifluoromethyl)- $2 H$-chromene $\mathbf{5 1 9}$ via intermediate formation of enones 520. The subsequent recyclization of 519 affording previously unknown 3(trifluoroacetyl)coumarins $\mathbf{5 2 1}$ in moderate to good yields. ${ }^{160}$

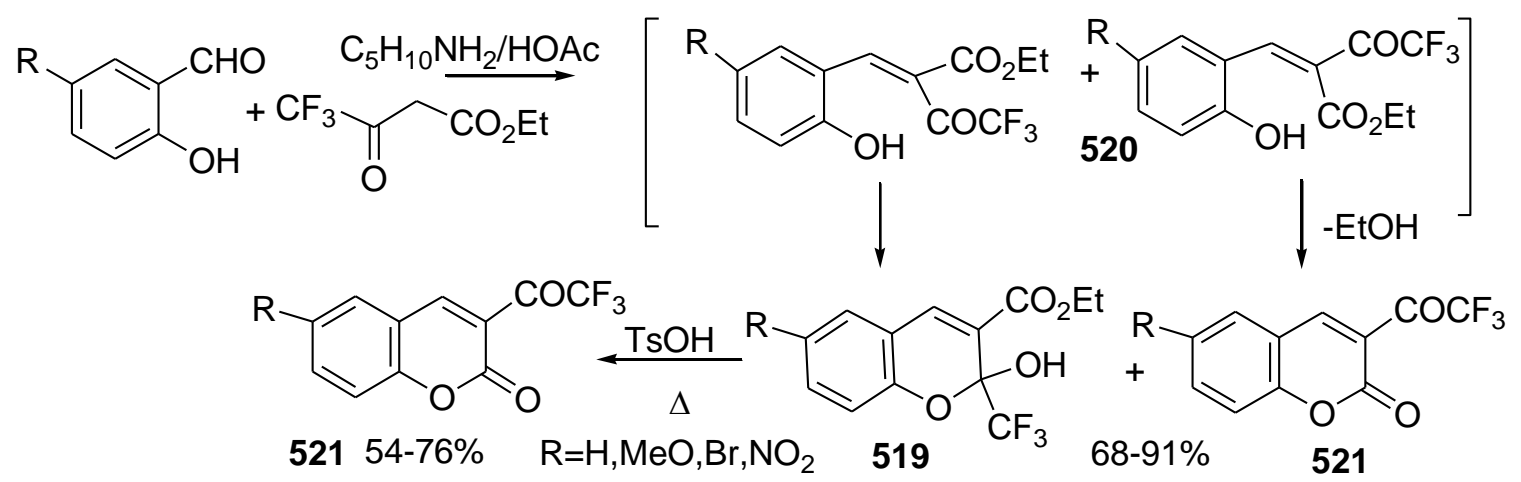

\section{Scheme 151}

The $\mathrm{Me}_{3} \mathrm{SiOTf}$-mediated reactions of dimethoxy-substituted $\mathrm{CF}_{3}$-enones $\mathbf{5 2 2}$ with 1,3bis(silyloxy)-1,3-butadienes $\mathbf{5 2 3}$ afford pyran-4-ones $\mathbf{5 2 4}$. $^{161}$

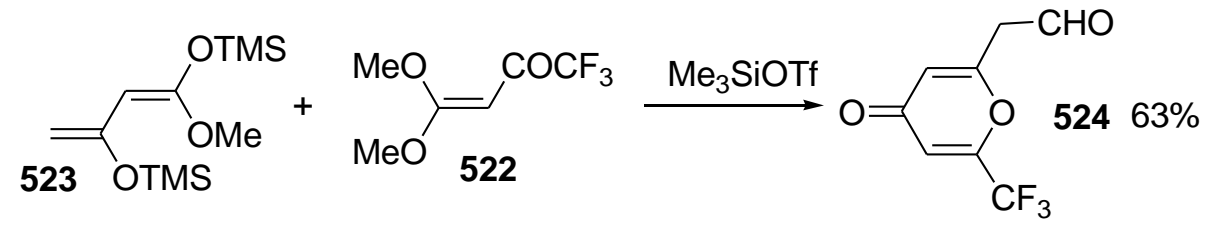

\section{Scheme 152}
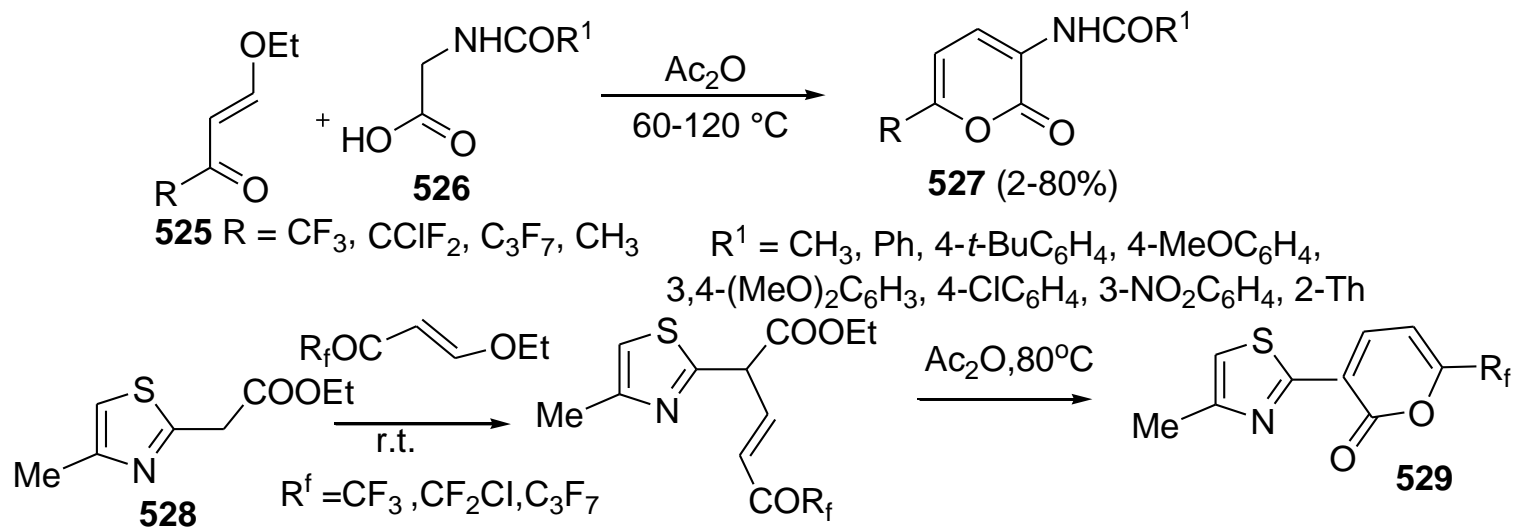

\section{Scheme 153}


The reaction of $\mathbf{5 2 5}$ with $\mathrm{N}$-aroyl glycines $\mathbf{5 2 6}$ in the presence of $\mathrm{Ac}_{2} \mathrm{O}$ leads to $2 \mathrm{H}$-pyran-2ones derivatives 527. The reaction between enones and thiazole $\mathbf{5 2 8}$ bearing a methylene group activated by an electron-withdrawing substituent leads to formations pyrones $\mathbf{5 2 9} .{ }^{162}$

3.2.4 Synthesis of pyrimidines and their derivatives. Trifluoromethylpyrimidines $\mathbf{5 3 0}$ are formed when $\beta$-ethoxyenone $\mathbf{5 3 1}$ is allowed to react with formamide in the presence of ammonia chloride or with the compounds of the urea series. ${ }^{163}$ 2-Bromo-4-(trifluoromethyl)pyrimidine 533 was prepared by reaction of $\mathbf{5 3 2}$ with phosphorus tribromide. ${ }^{164}$ Enamidoketone $\mathbf{5 3 4}$ was used for preparation of pyrimidine derivative 535. ${ }^{35}$ The heterocyclization was carried out under basic conditions.

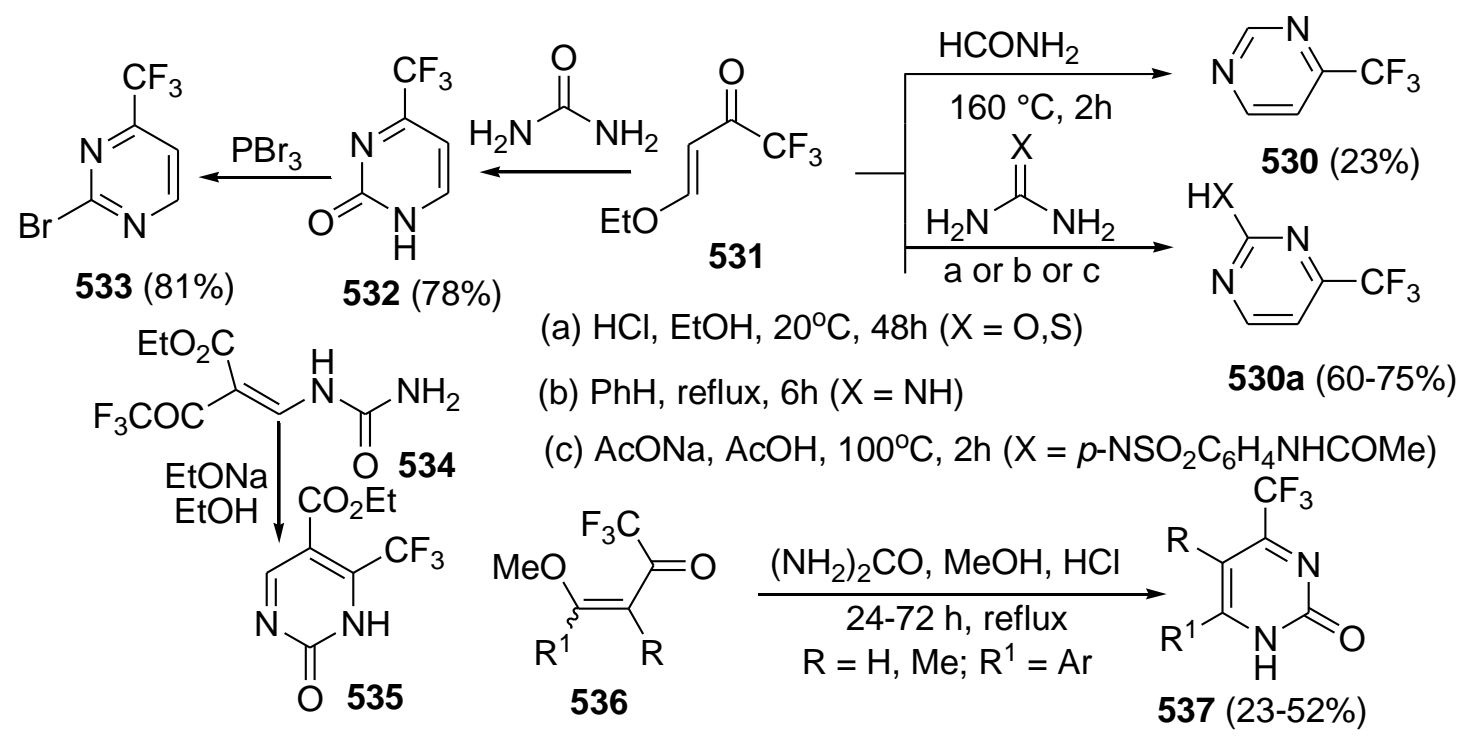

\section{Scheme 154}

The reactions of $\mathrm{CF}_{3}$-enone 538 containing the ethoxycarbonyl group in the $\alpha$-position with thiourea and guanidine sulfate gave the corresponding dihydro- 539 and tetrahydro-derivative 540 in moderate yields. ${ }^{110}$ The reaction of a sterically hindered trifluoromethyl enone $\mathbf{5 4 1}$ having an adamantane fragment with thiourea affords dihydropyrimidine $\mathbf{5 4 2} .{ }^{165}$

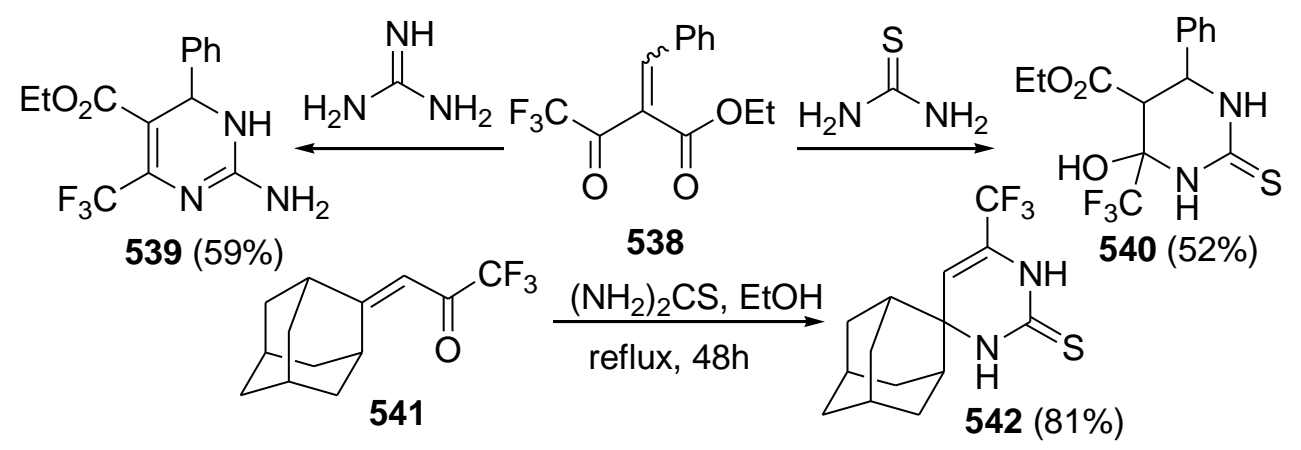

\section{Scheme 155}


Cyclic $\mathrm{CF}_{3}$-enones 543 were applied for the preparation of 2-pyrimidones 544 and their thioanalogous using the reaction with urea and thiourea. ${ }^{166}$

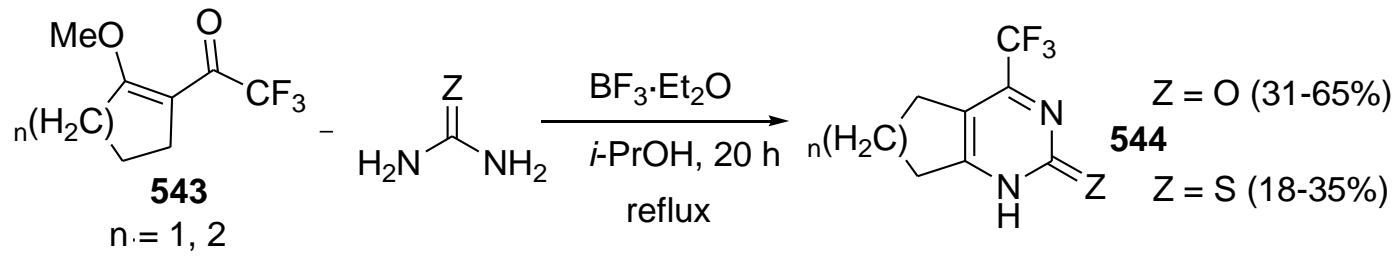

\section{Scheme 156}

The reaction of series of $\mathrm{CF}_{3}$-enones $\mathbf{5 4 5 a}, \mathbf{b}$ with acet- and benzamidine was carried out. ${ }^{167}$ The formation of pyrimidine $\mathbf{5 4 6}$ or the mixture of 546 and its tetrahydro-derivative $\mathbf{5 4 7}$ is observed. In the case of enones $\mathbf{5 4 5 b}$ subsequent dehydration and oxidation of intermediate adducts $\mathbf{5 4 8}$ without isolation permits preparation of $\mathbf{5 4 9}$ in high yields. The possibility of application of $\mathbf{5 5 1}$ for the synthesis of pyrimidine 552derivatives was shown. ${ }^{168}$
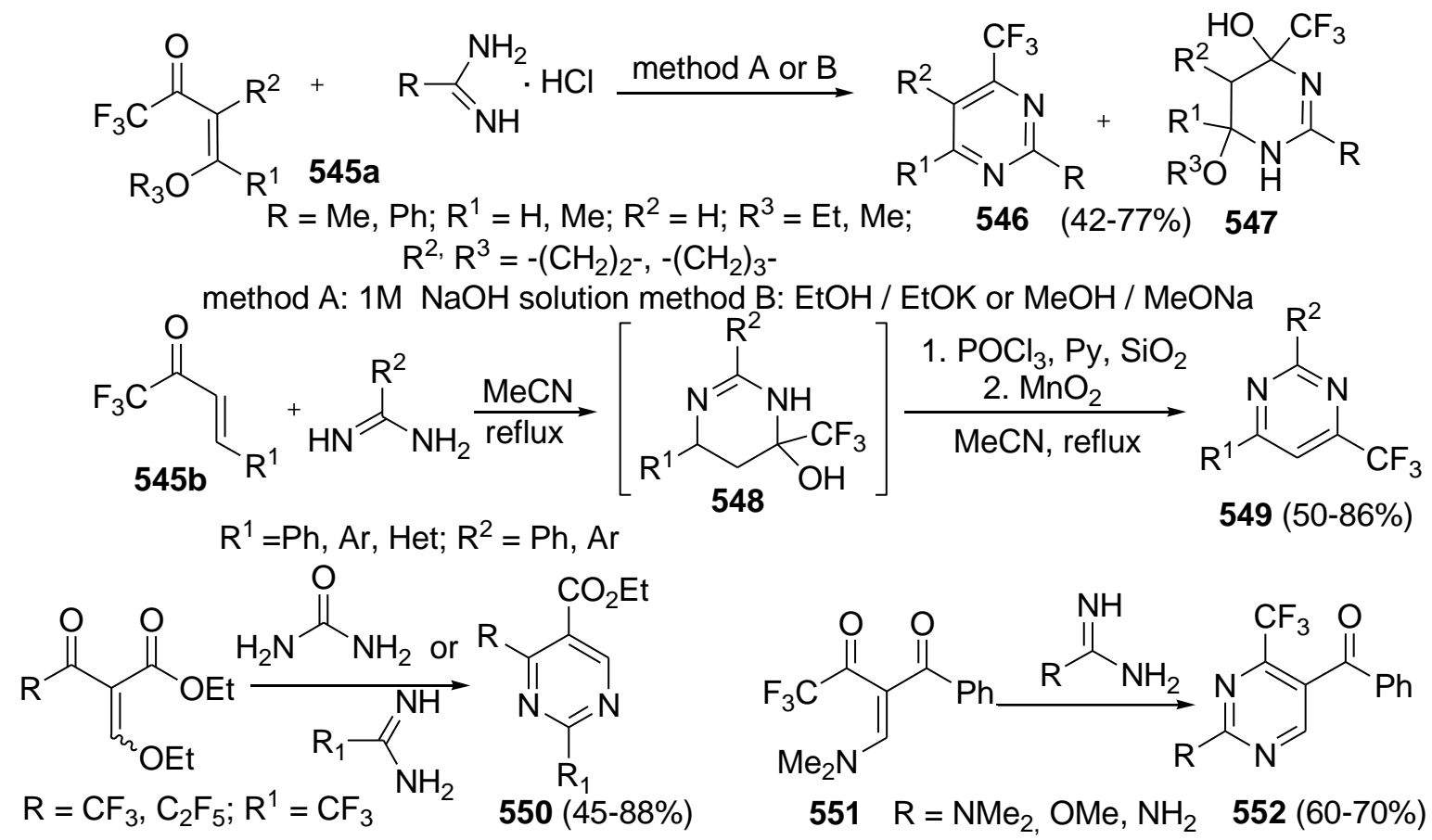

\section{Scheme 157}

The one-pot synthesis of substituted 2-acetylaminopyrimidines 554 using the reaction of $\mathbf{5 5 3}$ with 1-acetylguanidine was elaborated. The acetylamino group of 2-acetylaminopyrimidines can be hydrolyzed to afford the corresponding 2-aminopyrimidines 555. ${ }^{169}$ The N'-benzylidenehydrazino pyrimidines 556 were obtained through one-step cyclocondensation of N-guanidinobenzylimines and 4-alkoxyenones in good yields. Most heterocycles were isolated as a single diastereoisomer (E- 
isomers). ${ }^{170} \mathrm{~N}$-substituted pyrimidinones $\mathbf{5 5 7}$ were synthesized by condensation of enones $\mathbf{5 5 3}$ with excess $N$-methyl- and $N$-allylureas. ${ }^{171}$

The reaction of $\beta$ - alkoxyvinyl $\mathrm{CF}_{3}$ - ketones 553 with 2-methyl-2-thiopseudourea sulfate carried out in the presence of sodium hydroxide solution furnishing substituted 4-CF 3 -2-methylsulfanyltetrahydropyrimidines $\mathbf{5 5 8}$ in good yields, but the product was unstable and rapidly lost an alcohol and water molecule to give the parent aromatic pyrimidine 559. ${ }^{172}$ The compound 560 reacts with methylisothiouronium sulfate forming directly the corresponding pyrimidine $\mathbf{5 6 1}$ in moderate yield. ${ }^{64 a}$

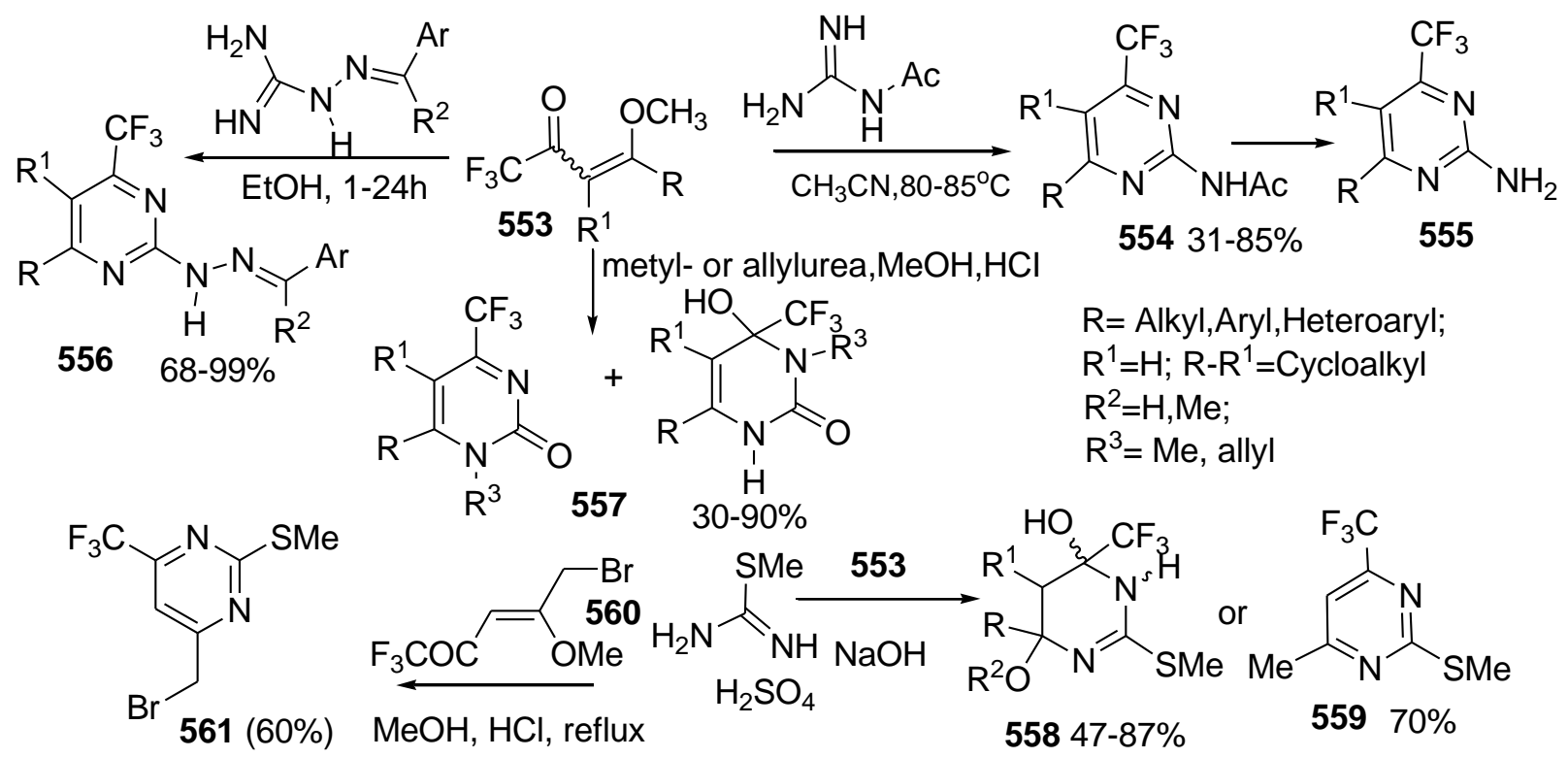

\section{Scheme 158}

The cyclocondensation of $\mathbf{5 5 3}$ toward the nonsymmetric dinucleophile - N-methylthiourea was choosen to study its regiochemistry. Depending on the temperature and the reaction time the openchain products 562 or pyridinethiones 563 were obtained. ${ }^{173}$

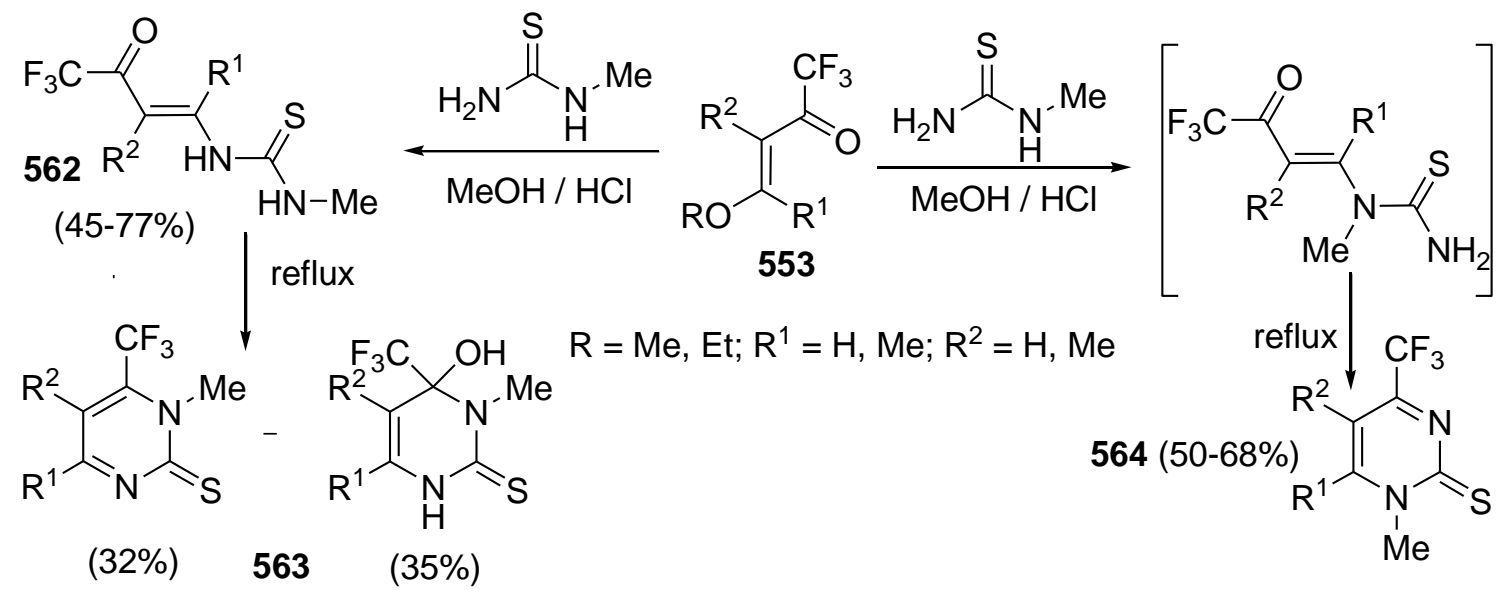

\section{Scheme 159}


Analogous reaction was used for synthesis of 2-dimethylamino-derivative $\mathbf{5 6 6}$ showed cardiotonic activity. ${ }^{174}$ The target product 566 was obtained in high yield.<smiles>CCOC(=O)c1cnc(N(C)C)nc1C(=O)OCC</smiles>

\section{Scheme 160}

The enaminodione $\mathbf{5 6 7}$ has been introduced in reactions with urea derivatives. The reaction with guanidine affords pyrimidine 568 in good yield. The reaction with $O$-methylisourea affords 1methoxypyrimidine 569 and 1-diethylaminopyrimidine 570 because diethylamine formed in the reaction reacts with methoxypyrimidine $\mathbf{5 6 9} .{ }^{84 \mathrm{~b}}$

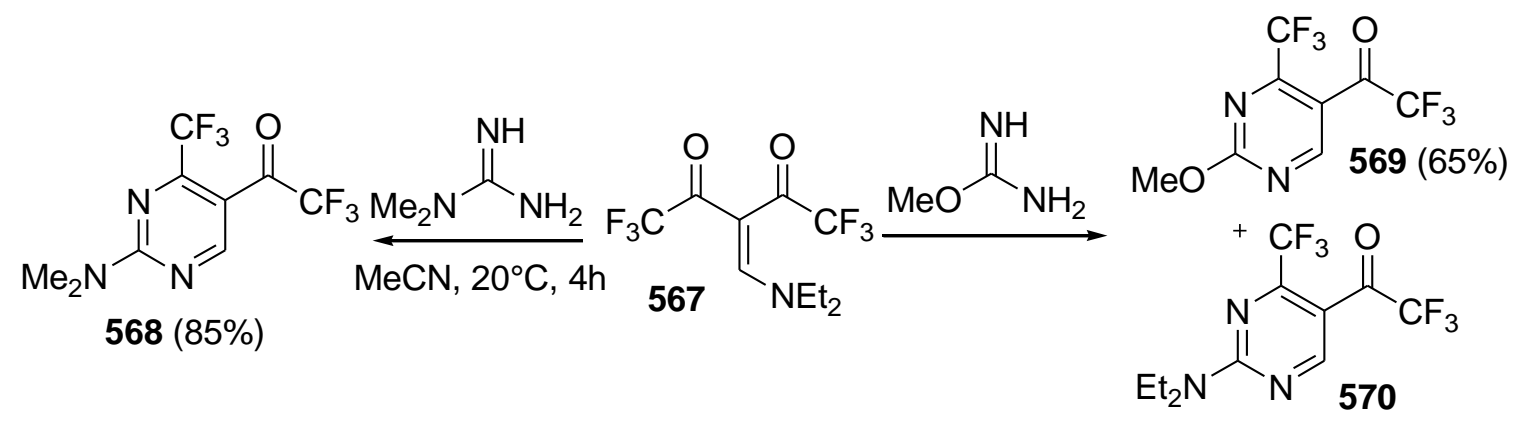

\section{Scheme 161}

The work was undertaken to apply the methodology of the synthesis of fluorinated aminopyrimidines analogous to trimethoprim (TMP) ${ }^{175}$ - the reference drug for prophylaxis and treatment of opportunistic infections due to Pneumocystis carinii and Toxoplasmagondii. Enaminoketones $\mathbf{5 7 1}$ were reacted with guanidine to give $\mathbf{5 7 2}$.

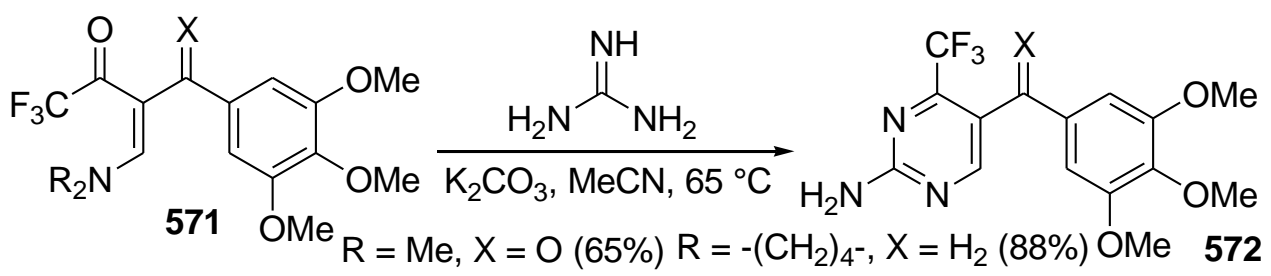

\section{Scheme 162}

Four novel pyrimidines were prepared to investigate the effects of on NTPDase activity in a synaptosomal fraction obtained from rat cerebral cortex. ${ }^{176}$ The pyrimidine $\mathbf{5 7 3}$ was prepared by the cyclocondensation reaction of $\mathbf{5 7 4}$ with 1,2-dimethyl-isothiourea. The synthesis of $\mathbf{5 7 5}$ was 
achieved from the cyclization of hydrazine $\mathbf{5 7 6}$ with the ketone $\mathbf{5 7 4}$. The pyrimidine $\mathbf{5 7 7}$ was prepared by the oxidation of 2-methylsulfanyl-pyrimidine 578 with MCPBA which underwent nucleophilic displacement of the 2-methylsulfonyl group by hydrazine hydrate to furnish the 2hydrazino-pyrimidine $\mathbf{5 7 6}$ in excellent yield.

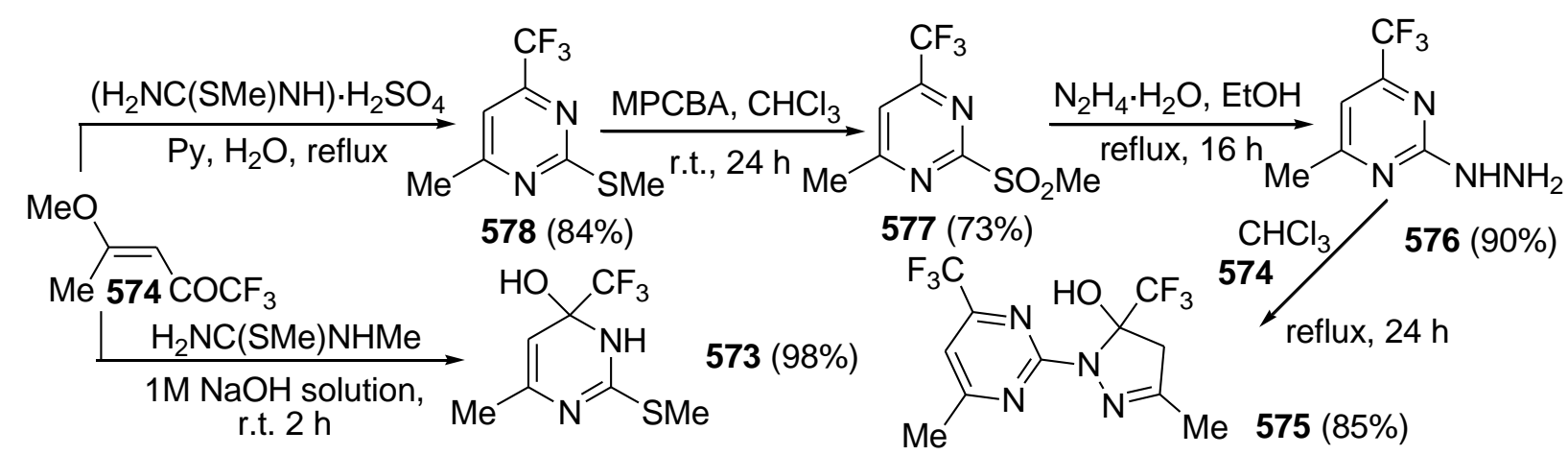

\section{Scheme 163}

The reaction of 2-guanidinopyrimidine 579 with 580 and cyclic enones 580a leads to dipyrimidylamines $\mathbf{5 8 1}$ or their condensed dihydrofuran and dihydropyran derivatives $\mathbf{5 8 2} .{ }^{177}$

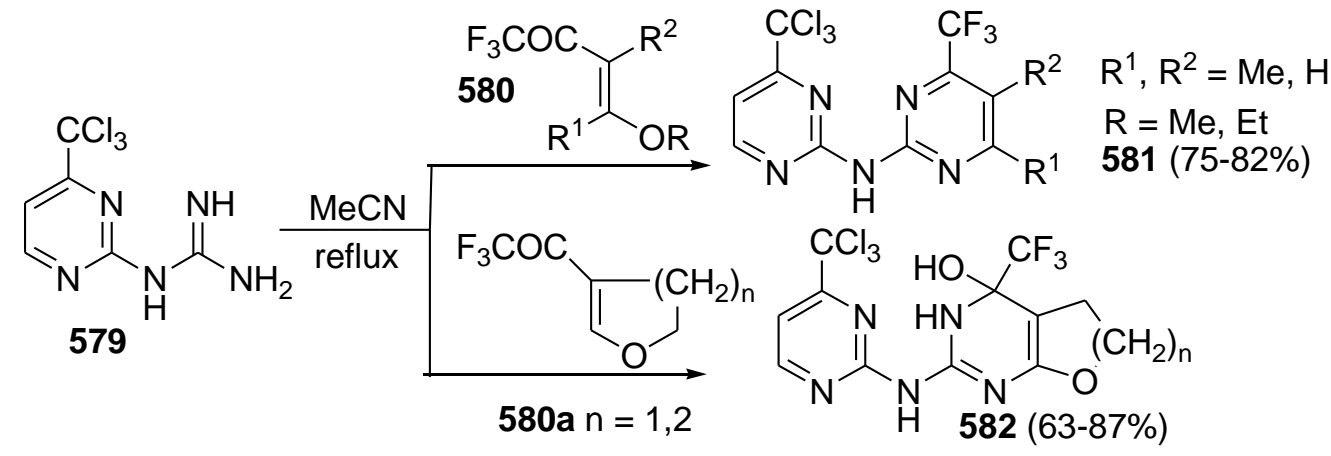

\section{Scheme 164}

Enaminoketone $\mathbf{5 8 3}$ reacts with various aldehydes in the presence of ammonia to give dihydropyrimidines $\mathbf{5 8 4}$ in good yields. Oxidation of $\mathbf{5 8 4}$ with DDQ at room temperature for 24h in acetonitrile caused smooth dehydrogenation to give the desired pyrimidines $\mathbf{5 8 5}$ having both trifluoromethyl and trifluoroacetyl groups which are not easily obtained by other methods. ${ }^{178}$<smiles>CCOC(=O)C(=O)C(=CN)C(=O)C(F)(F)F</smiles>

Scheme 165

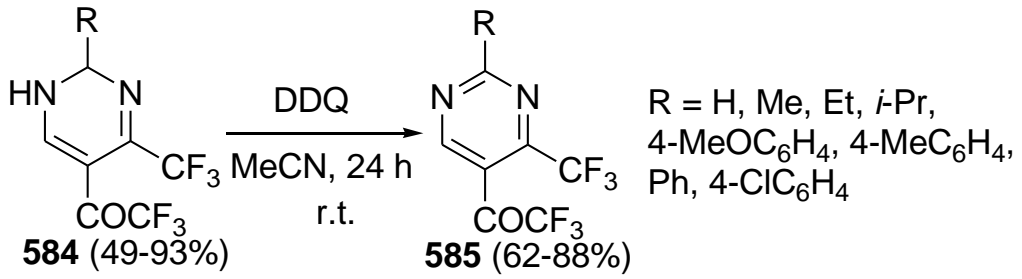


The reactions of $\mathrm{CF}_{3}$-enone $\mathbf{5 8 6}$ with several $\mathrm{N}, \mathrm{N}$-binucleophiles gave various 2-substituted pyrimidines $\mathbf{5 8 7}$ containing 1,3-dithiopropyl substituent. ${ }^{104}$<smiles>O=C(C=C1CCCCS1)C(F)(F)F</smiles>

586

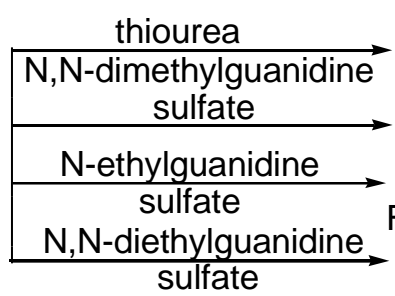

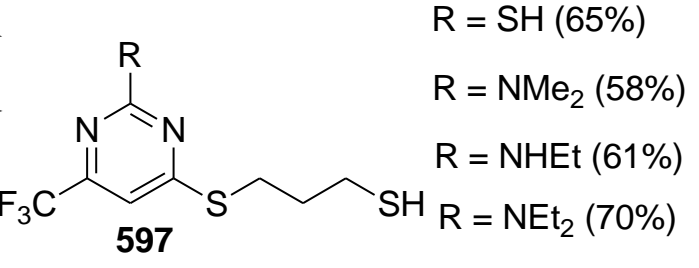

\section{Scheme 166}

The example of application of trifluoroacetyl pyrroline $\mathbf{5 8 8}$ for preparation of pyrimidines $\mathbf{5 8 9}$ was also described. In this case the reaction is less selective. Nevertheless, the products $\mathbf{5 8 9}$ are very attractive objects for medicinal chemistry. ${ }^{103}$

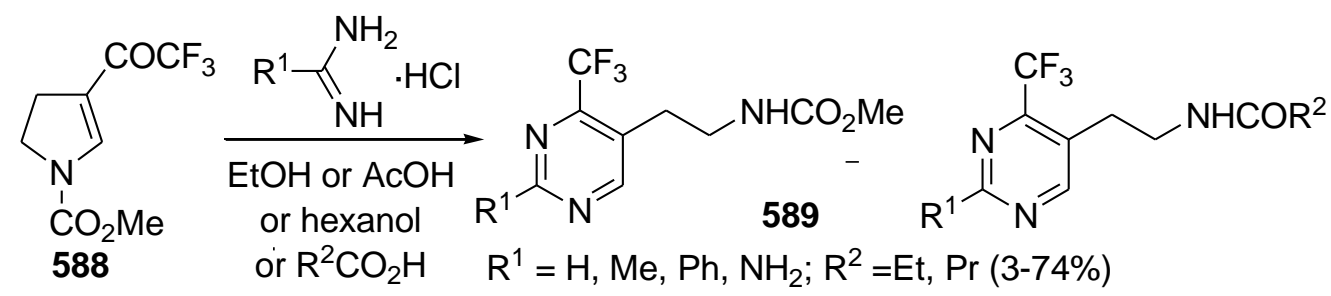

\section{Scheme 167}

The multicomponent reaction of $\mathrm{CF}_{3}$-enone 590, primary amine and formaldehyde was used for the synthesis of tetrahydropyrimidines $\mathbf{5 9 1}$ in moderate to high yields. ${ }^{179}$

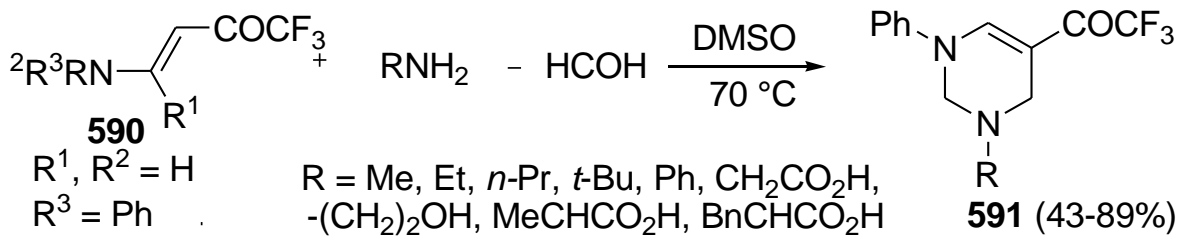

\section{Scheme 168}

$\beta$-Alkoxy- $\mathrm{CF}_{3}$-enones $\mathbf{5 9 2}$ were also used for preparation of various $\mathrm{CF}_{3}$-pyrimidines $\mathbf{5 9 3}$ containing 3-oxo-2,3-dihydropyrazole substituent. ${ }^{180}$ These compounds are of particular interest as the potential anti-inflammatory nonsteroid agents. Similarly pyrimidines 594 were synthesized by reaction of $\mathbf{5 9 5}$ with $\mathbf{5 9 2} .{ }^{181} \beta$-Trifluoroacetylstyrene reacts with aminoguanidine to give compound 597 containing tetrahydropyrimidine and pyrazoline moieties. In this case, water is eliminated only from the five-membered ring. ${ }^{110 \mathrm{a}}$ 


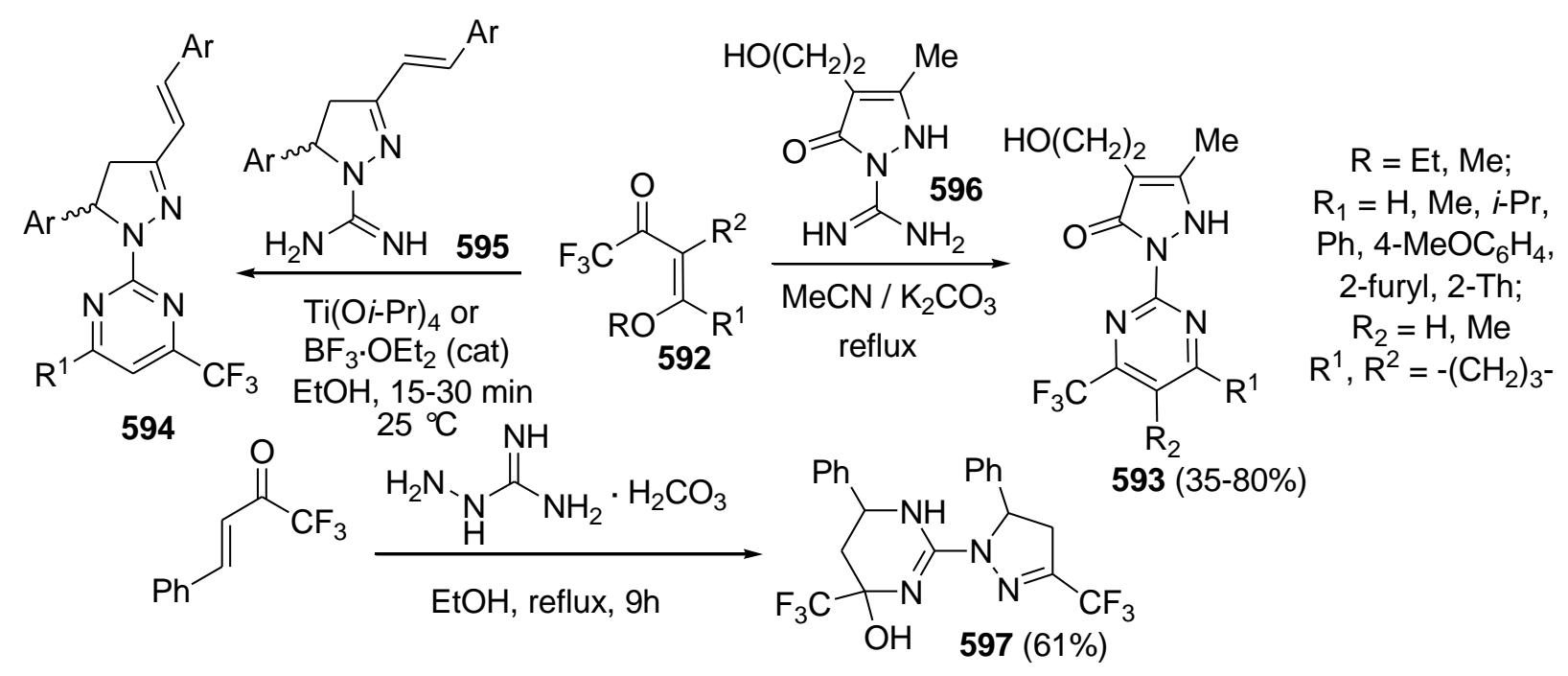

\section{Scheme 169}

3.2.5 Synthesis of $\mathbf{1 , 2}-\mathbf{1 , 3}$ - and 1,4-thiazines. The reaction of $\beta$-alkoxy- $\mathrm{CF}_{3}$-enones $\mathbf{5 9 2}$ with $S, S$ dimethylsulfoximine 598 gave 599 cyclized into the derivatives of 1,2-thiazine-1-oxide $\mathbf{6 0 0}$ in high yields. ${ }^{182}$

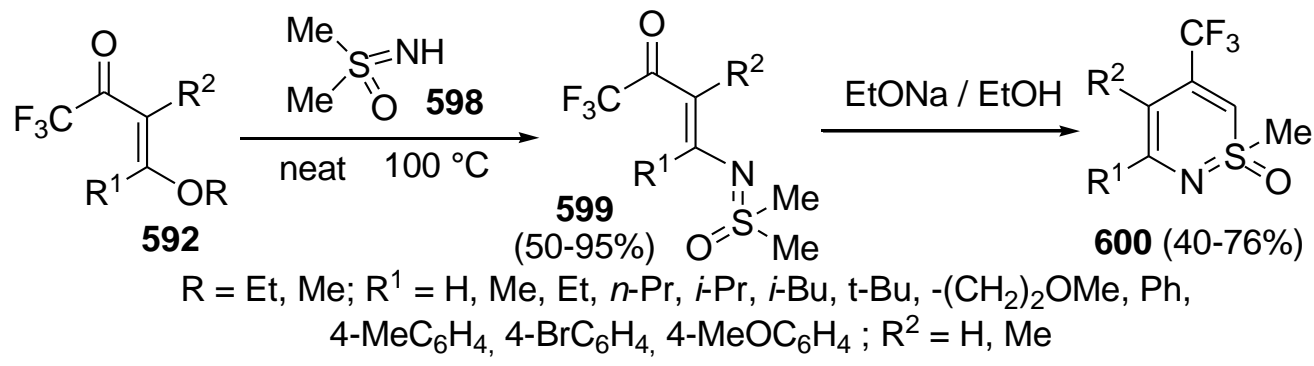

\section{Scheme 170}

The reactions of trifluoromethyl enones 601 with thiourea and thioacetamide in an acidic medium afford dihydrothiazines 602. Both reactions are regiospecific ones and give one isomer formed upon the addition of sulfur at the double bond and nitrogen of the carbonyl group. ${ }^{183}$

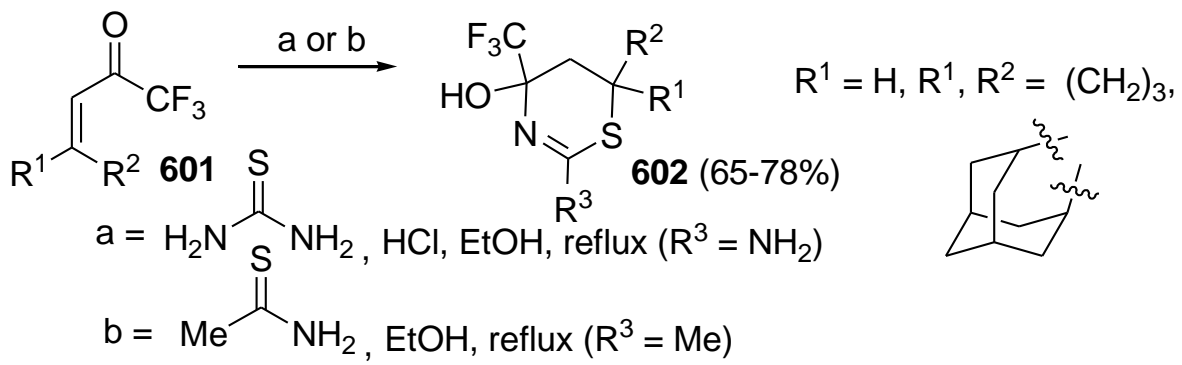

\section{Scheme 171}


The reaction of $\beta, \beta$-dibromo- $\mathrm{CF}_{3}$-ketone $\mathbf{6 0 3}$ with thioacetamide and thiourea lead regioselectively to the corresponding 1,3-thiazine derivatives $\mathbf{6 0 4}$ in good yields. ${ }^{15 \mathrm{e}}$<smiles>[R]c1nc(C(F)(F)F)cc(=S)s1</smiles>

\section{Scheme 172}

Dihydrothiazine 605 can be prepared using the reaction of ketone 606 with 2-aminoethanethiol with the subsequent oxidative cyclization of the adduct $\mathbf{6 0 7}$. The reaction with 2-aminothiophenol results in the formation of benzothiazine derivative 609 by heating. ${ }^{158}$

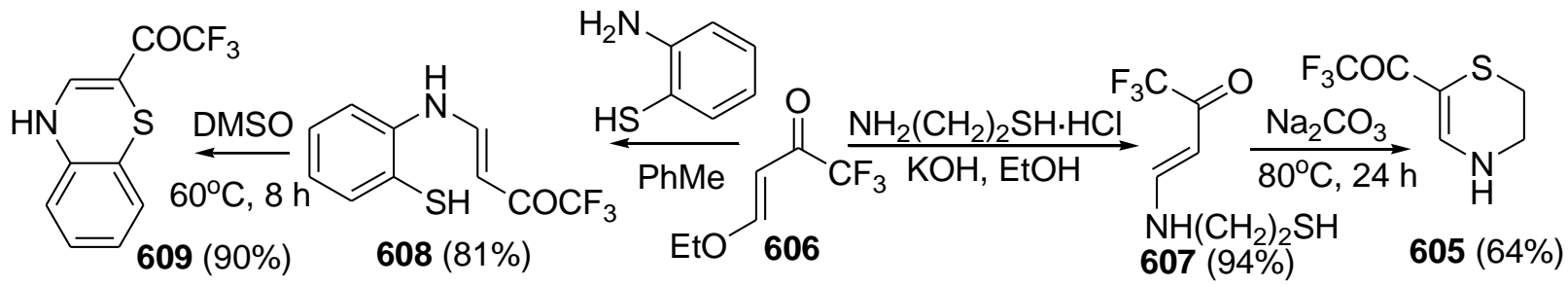

\section{Scheme 173}

3.2.6 Synthesis of 1,3-oxazines and 1,2,3-oxathiazines. The reaction of $\beta$-alkoxy- $\mathrm{CF}_{3}$-enones 610 with ethyl carbamate 611 leads to formation of enamidoketones 612. Subsequent reduction into 613 and cyclization to oxazines 614. One of the evaluated compounds 614 exhibited significant activity against tested microorganism strains. ${ }^{184}$

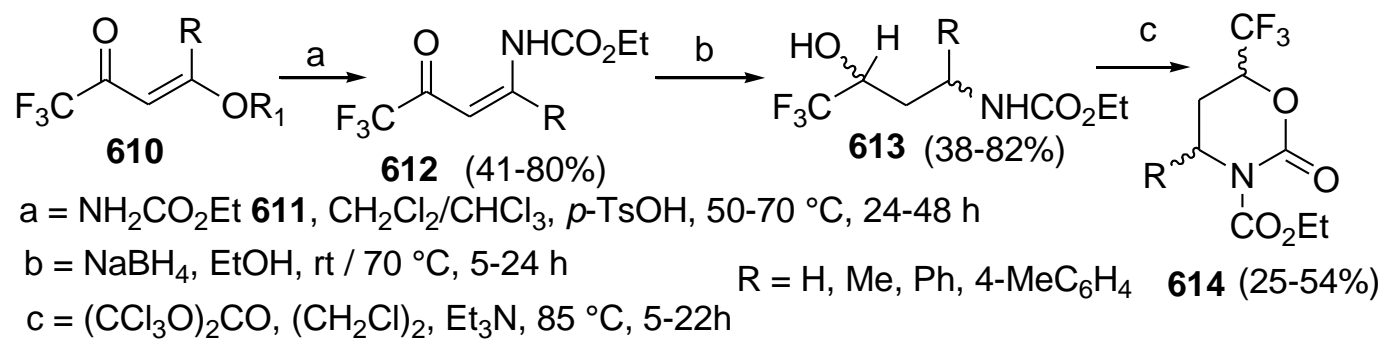

\section{Scheme 174}

\subsection{Synthesis of seven-membered heterocycles}

3.2.1 Synthesis of 1,4-diazepines (benzoanalogues) and 1,5-benzoxazepines. 5-Trifluoromethyl2,3-dihydro-1,4-diazepines $\mathbf{6 1 5}$ were prepared by the reaction of $\mathrm{CF}_{3}$-enone $\mathbf{6 1 6}$ with 1,2propylenediamine. ${ }^{43 \mathrm{~b}}$ The reaction gave two isomeric products $\mathbf{6 1 5 a , b}$ in a nearly 1:1 ratio. Similarly 1,4-diazepines 617 were prepared in good yields with ethylenediamine using microwave 
irradiation (MW), whereas carrying out the reaction in refluxing xylene resulted in a complicated mixture of products. ${ }^{185}$ Benzodiazepines have been considered the most extensively consumed psychoactive drugs worldwide due to their anxiolytic and anticonvulsant activity.

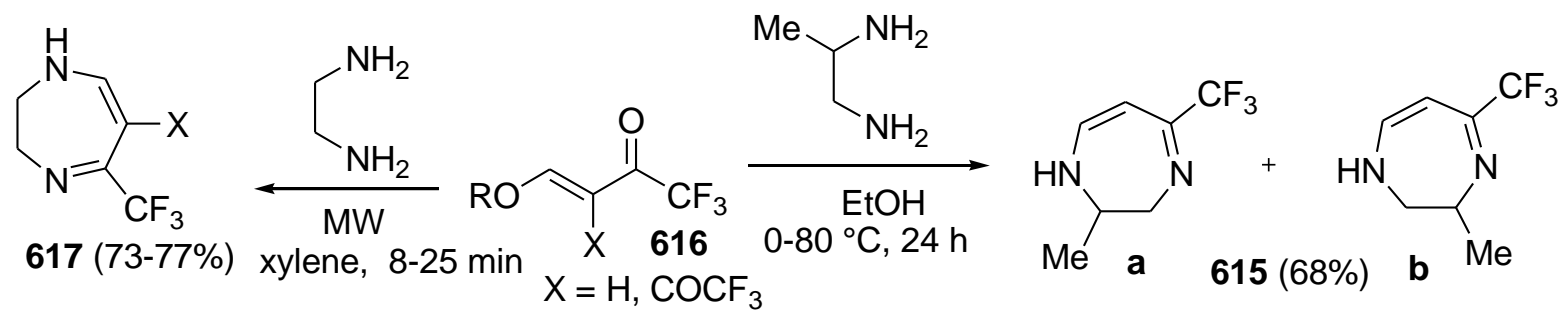

\section{Scheme 175}

The high yield preparation of benzodiazepines 618 by one-step reaction of 619 with ophenylendiamines was shown. The reactions with o-aminophenol or o-aminothiophenol yield 1,5oxazepines or 1,5-thiazepines 620 respectively. The reaction of trifluoromethyl enones $\mathbf{6 2 1}$ having no eliminating group in $\beta$-position with o-phenylenediamine affords $\mathbf{6 2 2} .{ }^{186}$

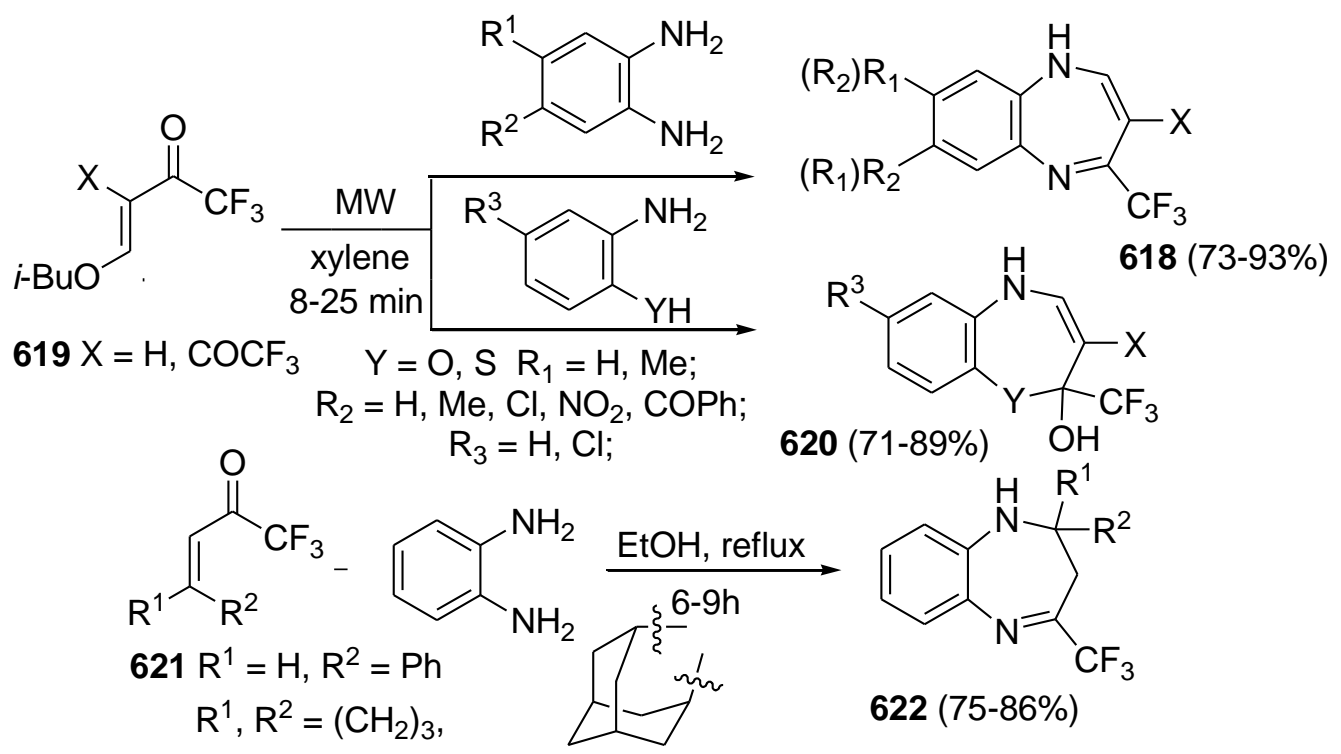

\section{Scheme 176}

The trifluoromethyl-4,5-dihydro-3H-pyrido[2,3-b][1,4]diazepin-4-ols $\mathbf{6 2 3}$ were obtained by cyclocondensation of 4-methoxy- $\mathrm{CF}_{3}$-enones $\mathbf{6 2 4}$ with 2,3-diaminopyridine. The reactions proceed regiospecifically in a moderate to good yields. ${ }^{187}$ The compounds $\mathbf{6 2 3}$ were also obtained from intramolecular cyclization reaction of the respective trifluoroacetyl enamines 625 . 


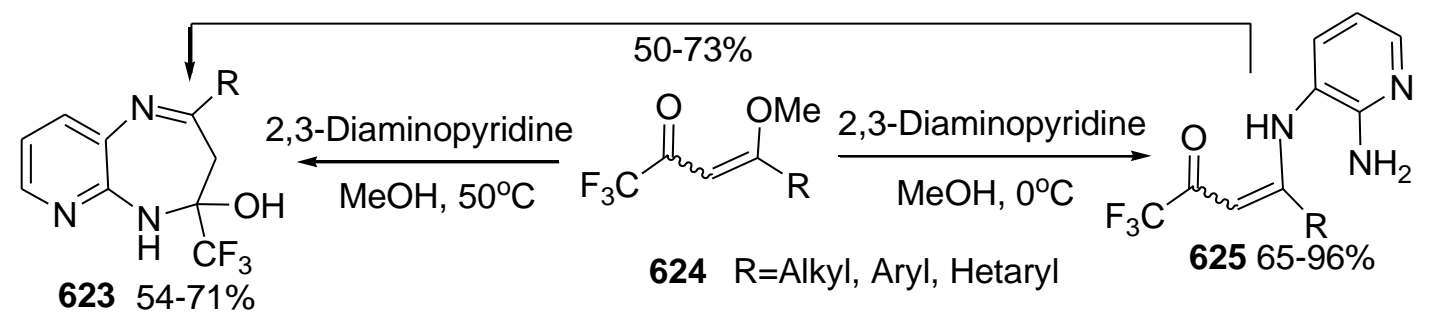

\section{Scheme 177}

Useful approach to the preparation of new $\mathrm{CF}_{3}$-containing 1,5-benzoxazepines $\mathbf{6 2 6}$ was presented. The reaction of enaminoketones 627 with DMF-DMA results in the corresponding dienamines 628. Its cyclization with $\mathrm{H}_{2} \mathrm{SO}_{4}$ give the fluorinated 1,5-benzoxazepines $626 .{ }^{188}$

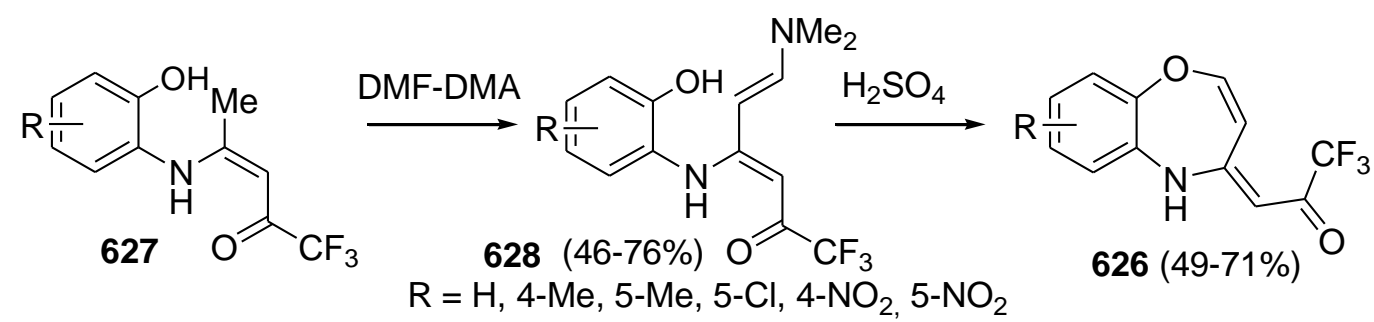

\section{Scheme 178}

\subsection{Synthesis of other condensed heterocycles}

Treatment of enaminoketone $\mathbf{6 2 9}$ with methylamine or acetic acid leads to the formation of $2-\mathrm{CF}_{3}-$ benzimidazole 630. The destruction of skeleton of the starting ketone $\mathbf{6 2 9}$ takes place. ${ }^{43 \mathrm{~b}}$

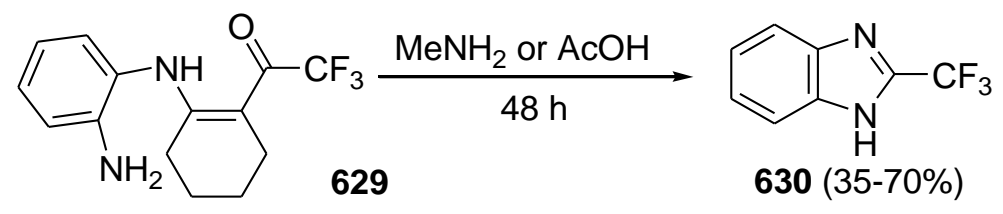

\section{Scheme 179}

The benzimidazolyl- and benzoxazolyl $\mathrm{CF}_{3}$-ketones $\mathbf{6 3 1}$ were obtained in high yields in the reaction of $o$-phenylendiamine and $o$-aminophenol with $\beta, \beta$-dibromoketone 632a and diethoxyketone 632b. ${ }^{101}$

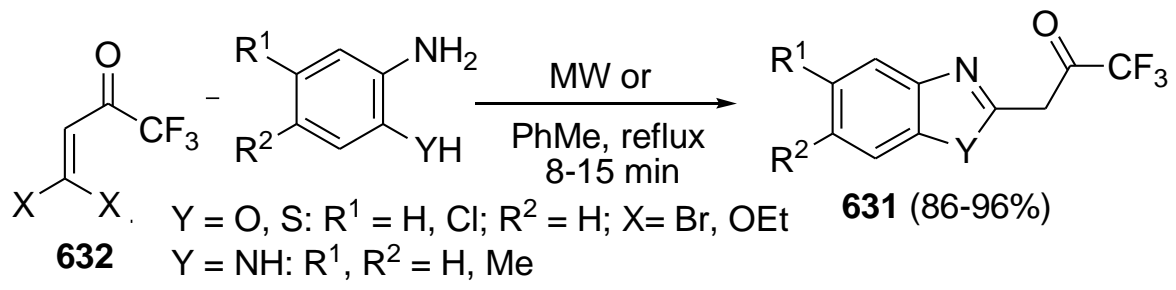

\section{Scheme 180}


Ketone 632b was applied for the synthesis of triazadibenzocrysenes 633. These polycondensed heterocycles containing various substituents were prepared in good yields from 2perimydinylamines 634. ${ }^{189}$

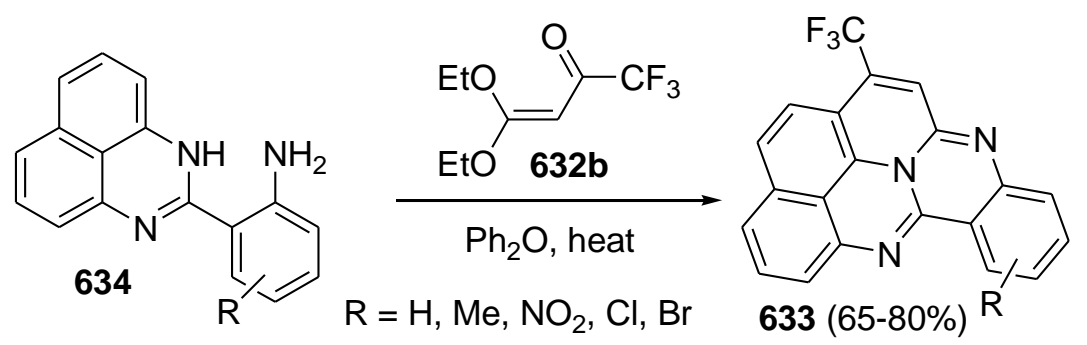

\section{Scheme 181}

The pyrimidine derivatives 635 have been prepared by the reaction of 636 with aminotriazoles and aminotetrazoles. The intermediate tetrahydro derivatives 637 were obtained as single diastereomer. ${ }^{190}$ The analogous reaction was investigated for $\beta$-enaminoketone 638. The reaction leads directly to condensed heterocyclic compounds 639, bypassing the intermediate tetrahydro derivatives. The reaction proceeds in $100 \%$ regioselective manner. ${ }^{191}$

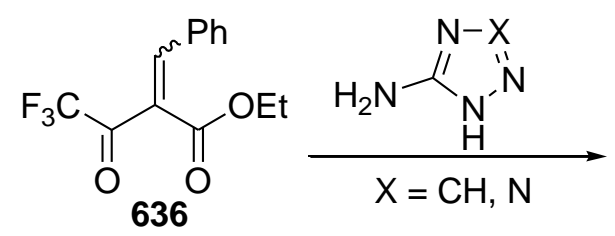

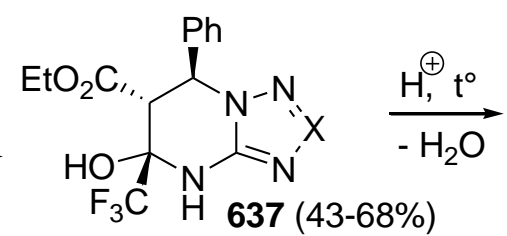<smiles>CCOC(=O)C1=C(C(F)(F)F)Nc2nnnn2C1c1ccccc1</smiles>

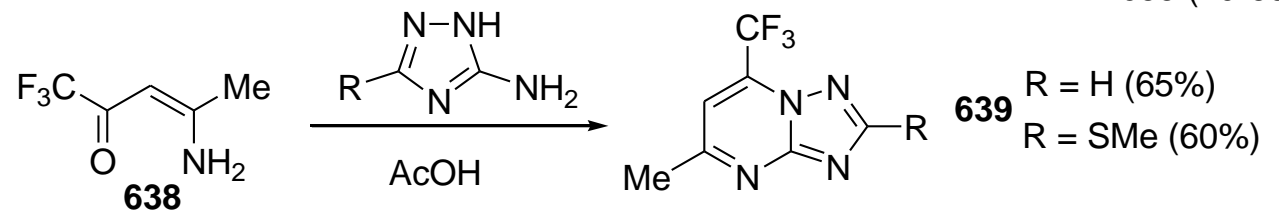

\section{Scheme 182}

The reaction of $\mathrm{CF}_{3}$-enone 640 with aminoazoles was used for the preparation of dihydro- 641 and tetrahydroazolopyrimidines 642. In case of aminotriazole and aminotetrazole the reaction proceeds $100 \%$ stereoselectively to form $\mathbf{6 4 2}$ having cis-orientation of $\mathrm{CF}_{3}$ - and $\mathrm{Ph}$ - groups. ${ }^{192} \mathrm{An}$ effective and regioselective method for the synthesis of $7-\mathrm{CF}_{3}$ substituted azolopyrimidines 643 from $\mathrm{CF}_{3}$-ketones 644 with 5(3)-aminoazoles was proposed. ${ }^{193}$ 


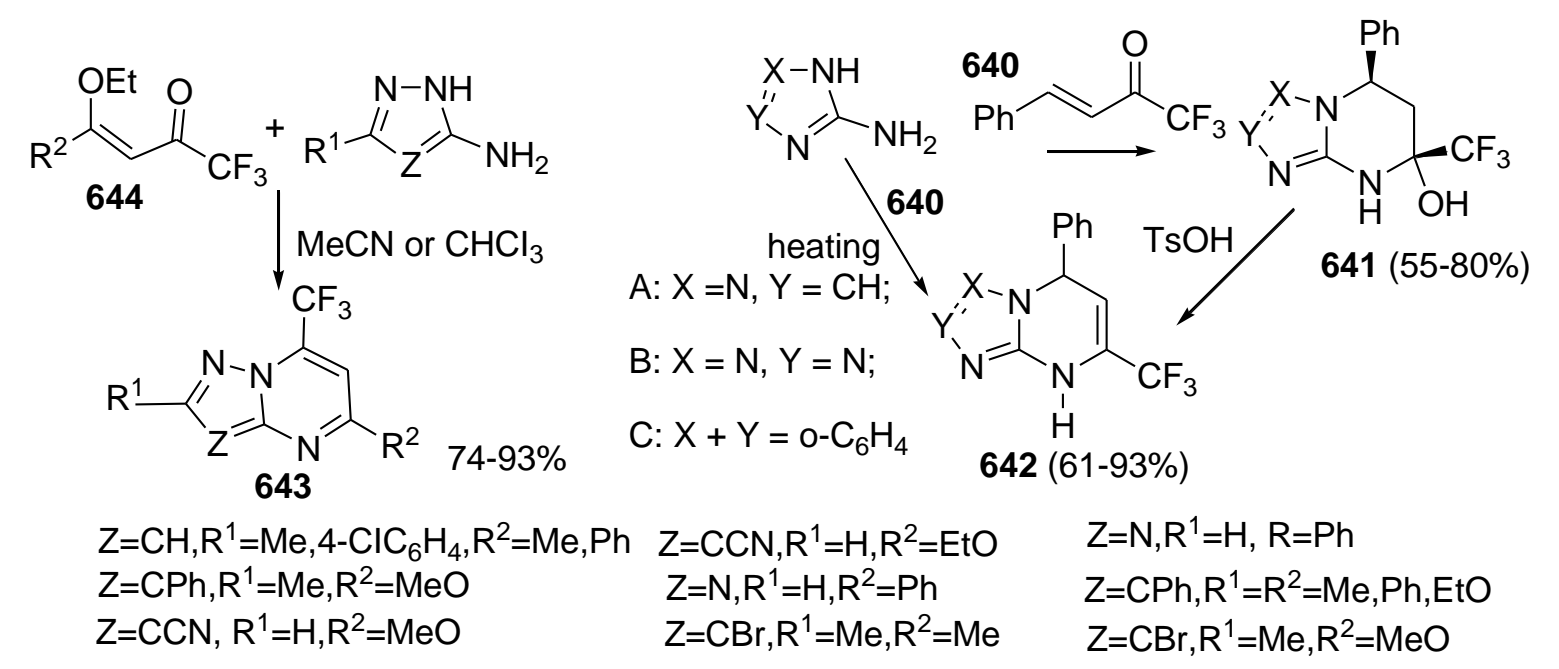

\section{Scheme 183}

The condensation of 6-aminouracil derivatives 647 and $\mathrm{CF}_{3}$-enones 648 provides preparation of $\mathrm{CF}_{3}$-derivatives of pyrido[2,3-d]pyrimidine $\mathbf{6 4 5 a} \mathbf{a}, \mathbf{b}$ and dihydro-derivative $\mathbf{6 4 6} .{ }^{194}$

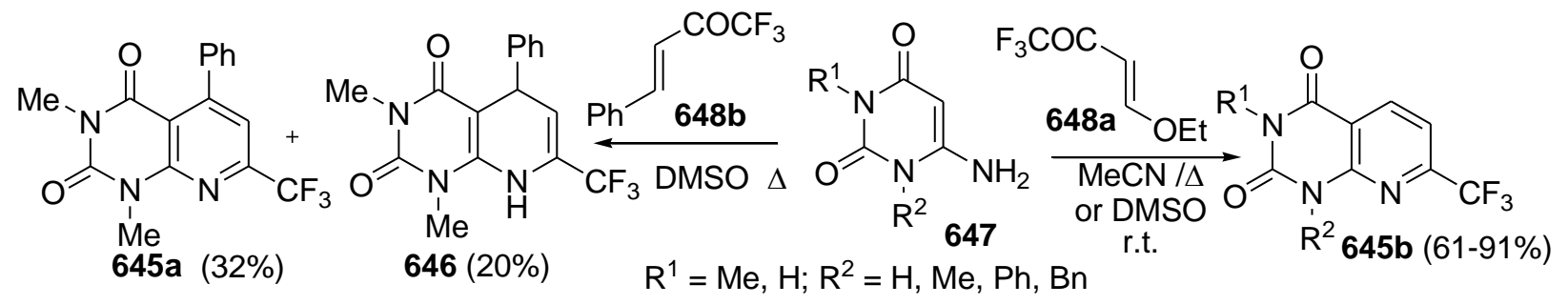

\section{Scheme 184}

Photoinduced cyclization of uracil-substituted ketones 649 having sulfimino-substituent was used for the preparation of pyrrolo[2,3-d]pyrimidine-2,4-diones 650 containing $\mathrm{CF}_{3}$-group. ${ }^{53}$

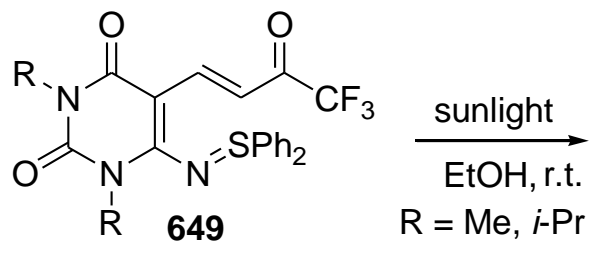<smiles>[R5]N1C(=O)c2cc(C(=O)C(F)(F)F)[nH]c2N(P)C(=O)N1[R6]</smiles>

\section{Scheme 185}

In a similar manner, the reaction of 5-aminopyrazole $\mathbf{6 5 1}$ or aminopyrazolo[3,4-b]pyridine derivatives 652 gives rise to formation of condensed pyridine systems 653-655. On exposure to microwave radiation trifluoromethyl-substituted derivatives of pyrido[2', $\left.3^{\prime}: 3,4\right]$ pyrazolo[1,5a]pyrimidine $\mathbf{6 5 5}$ are formed in good yields from ketones $\mathbf{6 5 6} .^{195}$ 


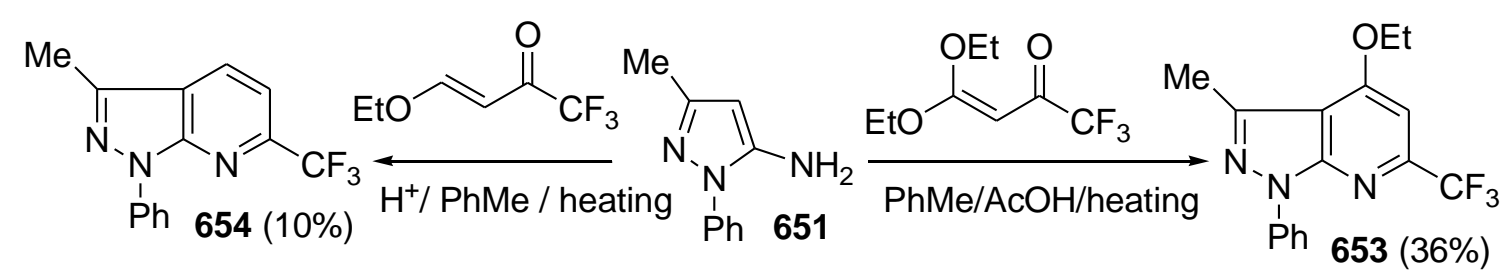

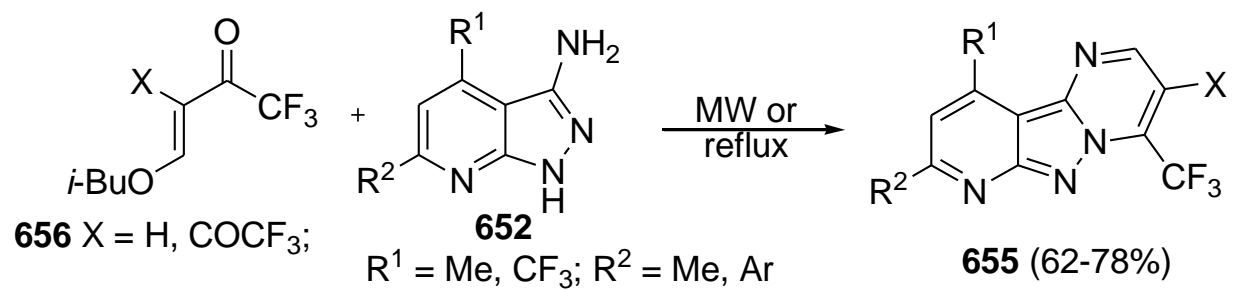

\section{Scheme 186}

The corresponding pyrido[1,2-a]pyrimidine derivatives 657 are formed in good yields by heating the dienone $\mathbf{6 5 8}$ in toluene or acetic acid solution. ${ }^{131 b}$

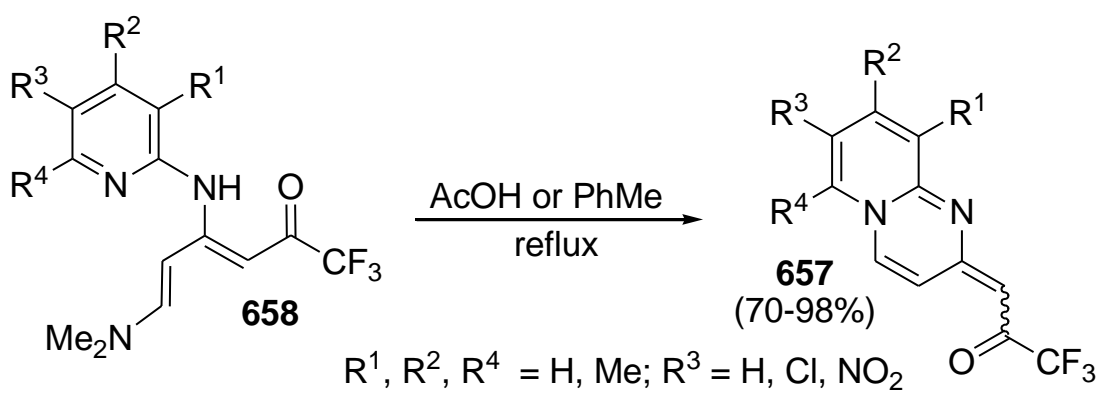

\section{Scheme 187}

The reaction of ketones $662(\mathrm{X}=\mathrm{Cl}, \mathrm{Br}, \mathrm{I})$ with 2-aminopyridine leads to imidazopyridine 663 . In case of $\mathrm{X}=\mathrm{Cl}$ the formation of mixture of two products is observed. It was shown that the reaction of ketone 659 with pyridinium (isoquinolinium) salts 660 in the presence of the base leads to indolizines $\mathbf{6 6 1}$ due to the oxidation of intermediate dihydroderivatives with air. ${ }^{196}$

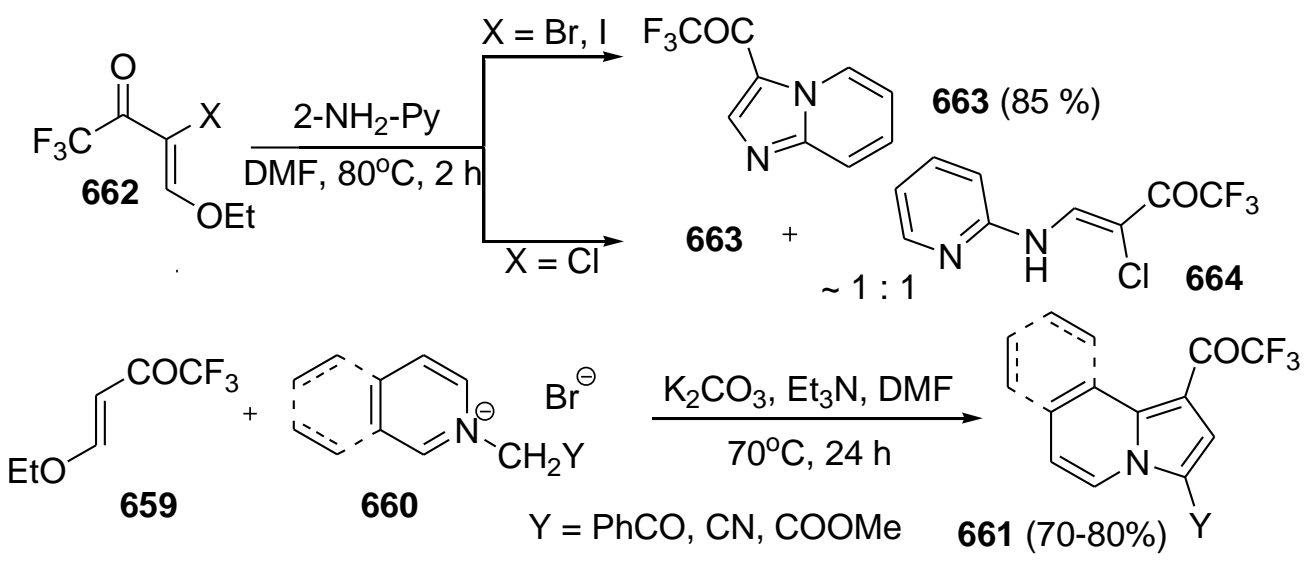

\section{Scheme 188}


The synthesis of imidazopyridines 665 using the reaction of 666 with several 2-aminopyridines was described. The reaction proceeds regio- and stereoselectively (the intermediate dihydroderivatives 667 were isolated as the single diastereomer). This reaction is the exception of the commonly observed direction for the reaction of $\mathbf{6 6 6}$ with amines because usually it leads to the products of sulfonyl-group substitution. Noteworthy that the electrophilic attack is directed on $\mathrm{C}^{3}$ carbon atom of $\mathbf{6 6 6}$ due to the EWG properties of sulfonyl group. ${ }^{197}$

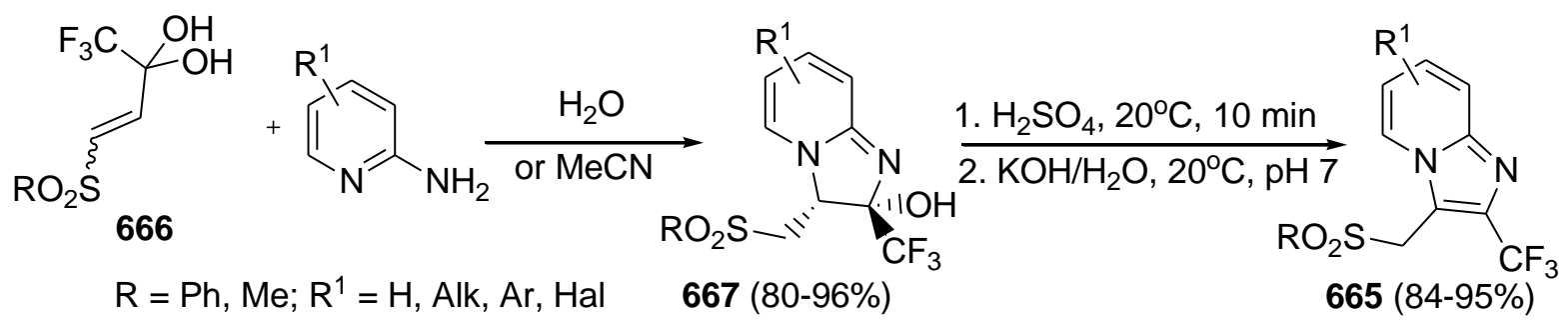

\section{Scheme 189}

The synthesis of various heterocyclic systems using the reaction of enones $\mathbf{6 6 6}$ with several diazoles was investigated. Reflux of $\mathbf{6 6 6}$ with 3-aminopyrazoles leads to formation of pyrazolopyrimidines 667a. In several cases, the isomeric pyrazolopyrimidines $\mathbf{6 6 7 b}$ were formed as the second product. Using aryl-substituted aminopyrazoles the reaction proceeded stereoselectively forming $667 \mathrm{a}$ as the only isomer. In the reaction of ketones 666 with 2 -amino- $1 H$-benzimidazole the formation of imidazopyridines $\mathbf{6 6 8}$ was observed. The analogous regioselectivity is observed in the reaction of enones $\mathbf{6 6 6}$ with various 3-amino-1,2,4-triazoles and 5-aminotetrazoles. 7Trifluoromethyl-substituted cycloadduct 669a dominates in most cases. However, the reaction in acetonitrile gave triazolopyrimidines $669 \mathbf{b} .^{198}$

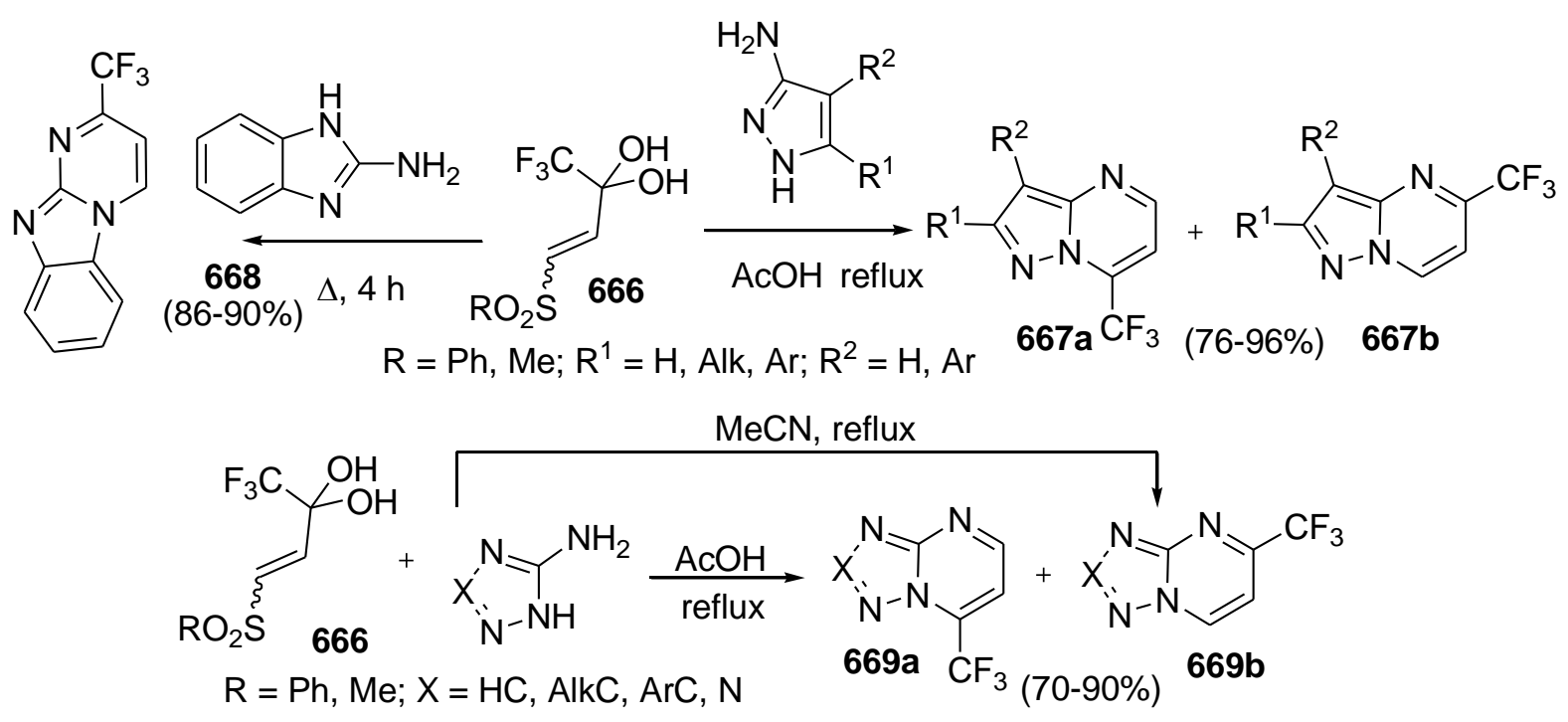

Scheme 190 
The reaction of 2-amino-1,3,4-thiadiazoles with $\mathbf{6 6 6}$ proceeds in high yields and with high stereoselectivity although the products 670 and 671 contain two asymmetric centers. This is probably due to hydrogen bond between hydroxy- and the phenylsulfonyl group. ${ }^{199}$

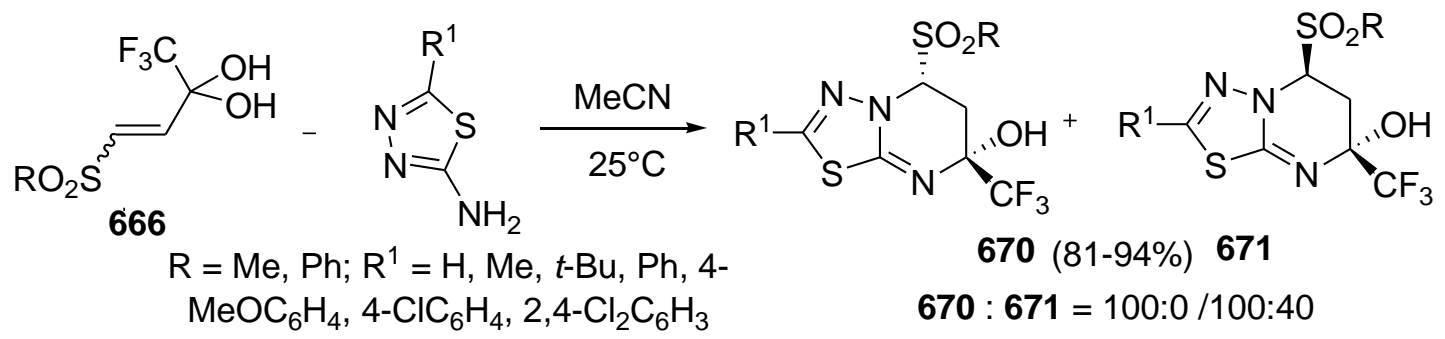

\section{Scheme 192}

As the scaffold for the construction of condensed heterocyclic systems several 2-aminothiazoles were used. The isomer 672a dominates among the products of this reaction. The effort to use 2amino-4-aryl-1,3-thiazoles failed because the reaction leads to predominate formation of enaminoketones 673 - the products of sulfonyl-group nucleophilic substitution. In the reaction of benzothiazoles the heterocycles $\mathbf{6 7 4}$ are formed as single reaction product only in the case of compounds having no substituent in the position 4. Furthermore, the cyclization with 2aminobenzothiazoles proceeds regio- and stereoselectively. ${ }^{200}$

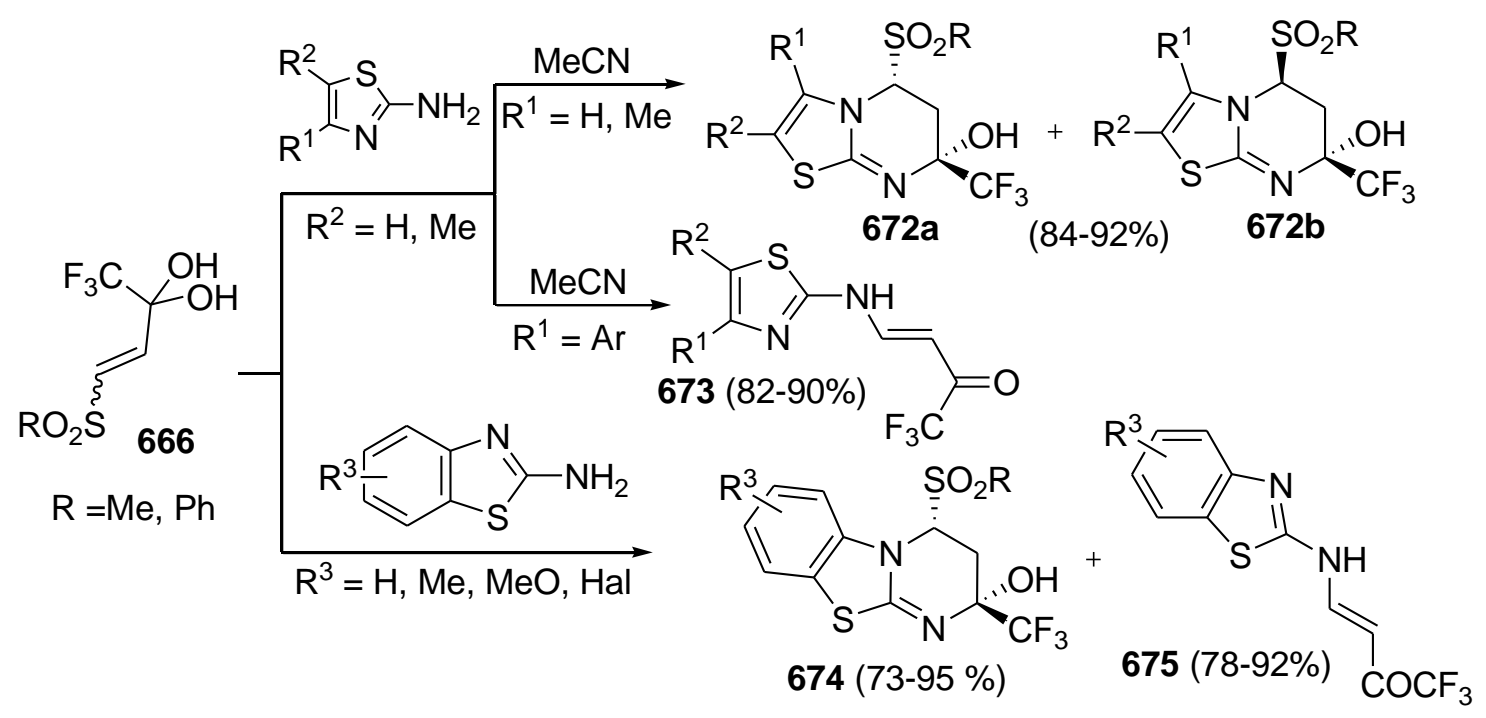

\section{Scheme 193}

The alkylation of pyridinethiones 676 with methyl iodide and $\omega$-bromoacetophenone was studied. The corresponding methylthio- and phenacylthio-derivatives of nicotinonitrile 677 were obtained in good yields. These compounds 677 were also used for heterocyclization into the corresponding benzoylthieno[2,3-b]pyridines 678 treating 677 with potassium hydroxide. ${ }^{201}$ 


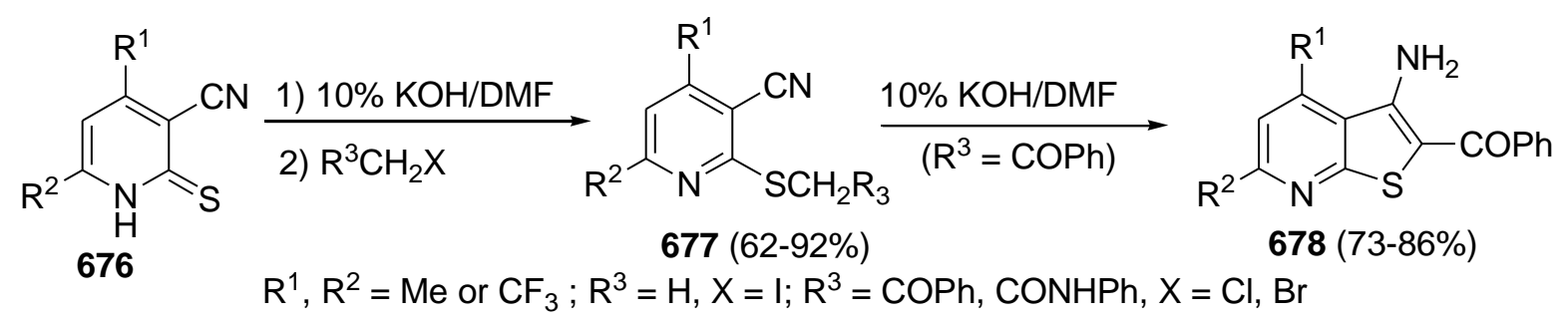

\section{Scheme 194}

The enone 679 can be applied for the preparation of the vinylogous of Vilsmeier-type reagent 680. The complex 680 can be used for the different purposes. For example, the reaction of 2,2'-bisindolyl 681 with 680 leads to formation of pentacyclic compound 682. The reaction of N,N'dipyrylmethane 683 with 680 leads to aldehyde 684 formation. ${ }^{202}$

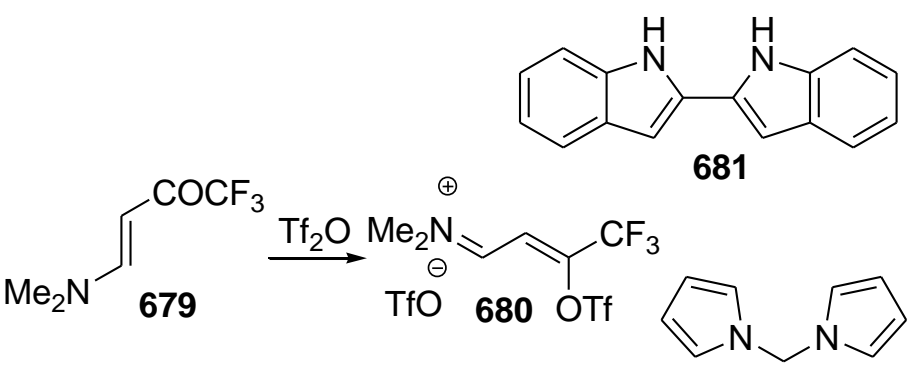

683 $\frac{1.680}{2 . \mathrm{OH}^{\ominus}}$

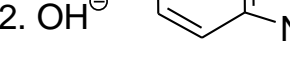

$682(86 \%)$<smiles>O=[R6]c1ccccc1-c1ccc(C(F)(F)F)c2c1=c1c=2[nH]c2ccccc12</smiles>

1.680<smiles>O=CCC1(C(F)(F)F)c2cccn2Cn2cccc21</smiles>

$684(55 \%)$

\section{Scheme 195}

\section{Conclusion}

Summarizing the facts given in the review, one might say that $\alpha, \beta$-unsaturated trifluoromethylketones exhibit a very high synthetic potential as molecular building blocks containing trifluoromethyl group. $\alpha, \beta$-Unsaturated trifluoromethylketones are widely used in modern organic synthesis, especially for the preparation of fluorinated heterocyclic compounds. However, the application of these very useful molecular building blocks is not restricted by this area.

The peculiarities of $\alpha, \beta$-unsaturated trifluoromethyl ketones are their high reactivity towards nucleophiles, as well as high chemo, regio- and stereoselectivity in these reactions. The distinctive trait is the stability of gem-hydroxy-trifluoromethyl fragments, sometimes very resistant to the action of dehydrating agents. 


\section{References}

1. (a) Nenajdenko, V. G.; Sanin, A. V.; Balenkova, E. S. Molecules 1997, 2, 186. (b) Nenajdenko, V. G.; Sanin, A. V.; Balenkova, E. S. Russ. Chem. Rev. 1999, 99, 483. (c) Druzhinin, S. V.; Balenkova, E. S.; Nenajdenko, V. G. Tetrahedron 2007, 63, 7753. (d) Erian, A. W. J. Het. Chem. 2001, 38, 793. (e) Kumar, V.; Aggarwal, R.; Singh, S. P. Heterocycles 2008, 75, 2893. (f) Zhu, S. Z.; Wang, Y. L.; Peng, W. M.; Song, L. P.; Jin G. F. Curr. Org. Chem. 2002, 6, 1057. (g) Pace, A.; Buscemi, S.; Vivona, N. Org. Prep. Proc. Int. 2007, 39, 1. (h) Pace, A.; Buscemi, S.; Vivona, N. Org. Prep. Proc. Int. 2005, 37, 447. (i) Muzalevskiy, V. M.; Shastin, A. V.; Balenkova, E. S.; Haufe, G.; Nenajdenko, V. G. Synthesis 2010, 23, 3905. (j) Serdyuk, O.; Butin, A.; Abaev, V. J. Fluorine Chem. 2010, 131, 296. (k) Furin, G. G. In Adv. Het. Chem.; Katritzky, A. R. Ed.; 2003, Vol. 86, p 129. (1) Furin, G. G. In Adv. Het. Chem.; Katritzky, A. R. Ed.; 2004, Vol. 87, p 273. (m) Furin, G. G. In Adv. Het. Chem.; Katritzky, A. R. Ed.; 2005, Vol. 88, p 231. (n) Silvester, M. J. Adv. Het. Chem.; Katritzky, A. R. Ed.; 1994, Vol. 59, p 1. (o) Burger, K.; Wucherpfennig, U.; Brunner, E.; Adv. Het. Chem.; Katritzky, A. R. Ed.; 1994, Vol. 60, p 1. (p) Burger, K.; Hennig, L.; Spengler, J.; Albericio, F. Heterocycles 2006, 69, 569. (q) Gakh, A.; Kirk, K. L. Fluorinated Heterocycles; Oxford University Press, 2008. (r) Petrov, V. A. Fluorinated Heterocyclic Compounds: Synthesis, Chemistry, and Applications.; John Wiley \& Sons, 2009.

2. (a) Hojo, M.; Masuda, R.; Kokuryo, Y.; Shioda, H.; Matsuo, S. Chem. Lett. 1976, 499. (b) Hojo, M.; Masuda, R.; Sakaguchi, S.; Takagawa, M. Synthesis 1986, 1016. (c) Colla, A.; Martins, M. A. P.; Clar, G.; Krimmer, S.; Fischer, P. Synthesis 1991, 483.

3. Hojo, M.; Masuda, R.; Kamitori, Y. Tetrahedron Lett. 1976, 17, 1009.

4. Mo, X-S.; Huang, Y-Z; Zhao, Y-R. J. Chem. Soc. Chem. Commun. 1994, 2769.

5. (a) Verboom, W.; Reinhoudt, D. N.; Harkema, V. S.; van Hummel, G. J. J. Org. Chem. 1982, 47, 3339. (b) Trabelsi, H.; Cambon, A. Tetrahedron Lett. 1995, 36, 3145.

6. (a) Vasil'tsov, A. M.; Shmidt, E. Yu.; Mikhaleva, A. I.; Zaitsev, A. B.; Tarasova, O. A.; Afonin, A. V.; Toryashinova, D. -S. D.; Il'icheva, L. N.; Trofimov, B. A. Russ. J. Org. Chem. 2001, 37, 334. (b) Zaitsev, A. B.; Shmidt, E. Yu.; Vasil'tsov, A. M.; Mikhaleva, A. I.; Morozova, L. V.; Ushakov, I. A.; Afonin, A. V.; Il'icheva, L. N. Russ. J. Org. Chem. 2003, 39, 1429.

7. Hojo, M.; Masuda, R.; Okada, E. Tetrahedron Lett. 1986, 27, 353.

8. (a) Hojo, M.; Masuda, R.; Okada, E. Synthesis. 1986, 1013. (b) Flores, A. F. C.; Brondani, S.; Zanatta, N.; Rosa, A.; Martins, M. A. P. Tetrahedron Lett. 2002, 43, 8701. (c) Bonacorso, H. G.; Martins, M. A. P.; Bittencourt, S. R. T.; Lourega, S. R. T.; Zanatta, N.; Flores, A. F. C. J. Fluorine Chem. 1999, 99, 177. (d) Hojo, M.; Masuda, R. J. Org. Chem. 1975, 40, 963.

9. Hojo, M.; Masuda, R.; Okada, E. Synthesis 1990, 347.

10. (a) Gorbunova, M. G.; Gerus, I. I.; Kukhar, V. P. Synthesis 2000, 738. (b) Gorlov, D. V.; Kurykin, M. A.; Petrova, O. E. Russ. Chem. Bull. 1999, 48, 1791.

11. (a) Levkovskaya, G. G.; Bozhenkov, G. V.; Larina, L. I.; Evstaf'eva, I. T.; Mirskova, A. N. Russ. J. Org. Chem. 2001, 37, 644. (b) Bozhenkov, G. V.; Levkovskaya, G. G.; Mirskova, A. N. Russ. J. Org. Chem. 2002, 38, 134. 
12. Cook, G.; Waddle, J. L. Terahedron Lett. 2003, 44, 6923.

13. Simchen, G.; Schmidt, A. Synthesis 1997, 117.

14. Schumann, D.; Naumann, A. Liebigs Ann. Chem. 1984, 1519.

15. (a) Kende, A. S.; Kun, L. Tetrahedron Lett. 1995, 36, 4035. (b) Magnus, P.; Hobson, L. A.; Westlund, N.; Lynch, V. Tetrahedron Lett. 2001, 42, 993. (c) Kende, A. S.; Liu, K.; Jos Brands, K. M. J. Am. Chem. Soc. 1995, 117, 10597. (d) Jokela, R.; Halonen, M.; Lounasmaa, M. Heterocycles 1994, 38, 189. (e) Lounasmaa, M.; Halonen, M.; Jokela, R.; Heterocycles 1995. 41, 807. (f) Halonen, M.; Jokela, R.; Lounasmaa, M. Heterocycles 1995, 41, 353. (g) Vronen, P. J. E.; Koval, N.; de Groot, A. Arkivoc 2004, (ii), 24.

16. Platoshkin, A. M.; Cheburkov, Yu. A.; Knunyants, I. L. Izv. Akad. Nauk SSSR, Ser. Khim. 1969, 112.

17. (a) Le'vy, J.; Soufyane, M.; Mirand, C.; Maindreville, M doe de.; Royer, D. Tetrahedron Lett. 1991, 5081. (b) Vasileva, E.; Sapi, J.; Laronze, J. -Y.; Mirand, C.; Levy, J. Monatch. Chem. 2002, 133, 151 .

18. Schreiber, S. L. Tetrahedron Lett. 1980, 21, 1027.

19. (a) Sunose, M.; Anderson, K. M.; Orpen, A. G.; Gallagher, T.; Macdonald, S. J. F. Tetrahedron Lett. 1998, 39, 8885. (b) Kawase, M.; Hirabayashi, M.; Koiwai, H.; Yamamoto, K; Miyamae, H. Chem. Comm. 1998, 641.

20. (a) Rashatasakhon, P.; Padwa, A. Org. Lett. 2003, 5, 189. (b) Padwa, A.; Rashatasakhon, P. Rose, M. J. Org. Chem. 2003, 68, 5139.

21. Lamarre, C.; Stella, L. Synlett 1999, 725.

22. (a) Nenajdenko, V. G.; Balenkova, E. S. Zh. Org. Khim. 1992, 28, 600. (b) Nenajdenko, V. G.; Gridnev, I. D.; Balenkova, E. S. Tetrahedron 1994, 50, 11023. (c) Nenajdenko, V. G.; Sanin, A. V.; Balenkova, E. S. Zh. Org. Khim. 1994, 30, 531. (d) Nenajdenko, V. G.; Balenkova, E. S. Zh. Org. Khim. 1993, 29, 687. (e) Nenajdenko, V. G.; Leshcheva, I. F.; Balenkova, E. S. Tetrahedron 1994, 50, 775. (e) Nenajdenko, V. G.; Sanin, A. V; Balenkova, E. S. Zh. Org. Khim. 1995, 31, 878.

23. Nenajdenko, V. G.; Balenkova, E. S. Tetrahedron 1994, 50, 12407.

24. Minami, Y.; Kuniyasu, H.; Miyafuji, K.; Kambe. N. Chem. Commun. 2009, 3080.

25. Neunhoeffer, O.; Alsdorf, G.; Ulrich, H. Chem. Ber. 1959, 92, 252

26. Fustero, S.; de la Torre, M. G.; Pina, B.; Fuentes, A. S. J. Org. Chem. 1999, 64, 5551.

27. (a) Keller, H.; Schlosser, M. Tetrahedron 1996, 52, 4637. (b) Nenajdenko, V. G.; Pronin, S. V.; Balenkova, E. S. Russ. Chem. Bull 2007, 335. (c) Sosnovskikh, V. Ya.; Usachev, B. I. Russ. Chem. Bull. 2004, 53, 383.

28. Uneyama, K.; Watanabe, H. Tetrahedron Lett. 1991, 32, 1459.

29. (a) Xiao, J.; Feng, Y.; Yuan, C. J. Chem. Soc., Perkin Trans. 1 2000, 4240. (b) Zhang, L.; Brookhart, M.; White, P. S. Organometallics 2006, 25, 1868. (c) Reznikov, V. A.; Volodarsky, L. B. Russ. Chem. Bull. 1996, 45, 1699. (d) Reznikov, V. A.; Roschupkina, G. I.; Mazhukin, D. G.; Petrov, P. A.; Popov, S. A.; Fokin, S. V.; Romanenko, G. V.; Rybalova, T. V.; Gatilov, Y. V.; Shvedenkov, Y. G.; Irtegova, I. G.; Shundrin, L. A.; Ovcharenko, V. I. Eur. J. Org. Chem. 2004, 749. 
30. Liebeskind, L. S.; Srogl, J. J. Am. Chem. Soc. 2000, 122, 11260.

31. (a) Mead, D.; Loh, R.; Asato, A. E.; Liu, R. S. H. Tetrahedron Lett. 1985, 26, 2873. (b) Mead, D.; Asato, A E.; Denny, M.; Liu, R. S. H.; Hanzawa, Y.; Taguchi, T.; Yamada, A.; Kobayashi, N.; Hosoda, A.; Kobayashi, Y. Tetrahedron Lett. 1987, 28, 259. (c) Gernert, D. L.; Ajamie, R. A.; Ardecky, R. A.; Bell, M. G.; Leibowitz, M. D.; Mais, D. A.; Mapes, C. M.; Michellys, P. Y.; Rungta, D.; Reifel-Miller, A.; Tyhonas, J. S.; Yumibe, N.; Grese, T. A. Bioorg. Med. Chem. Lett. 2003, 13, 3191. (d) Anshworth, I.; Hopes, P.; Levin, D.; Patel, I.; Salloo, R. Tetrahedron Lett. 2002, 43, 4931.

32. Gazit, A.; Rappoport, Z. J. Chem. Soc., Perkin Trans. 1 1984, 2863.

33. Cadierno, V.; Diez, J.; Garcia-Garrido, S. E.; Gimeno, J.; Nebra, N. Adv. Synth. Catal. 2006, 348, 2125.

34. (a) Pryadeina, M. V.; Kuzueva, O. G.; Burgart, Ya. V.; Saloutin, V. I.; Lyssenko, K. A.; Antipin, M. Yu. J. Fluorine Chem. 2002, 117, 1. (b) Katsuyama, I.; Funabiki, K.; Matsui, M.; Muramatsu, H.; Shibata, K. Chem. Lett. 1996, 179.

35. Palanki, M. S. S.; Gayo-Fung, L. G.; Shevlin, G. I.; Erdman, P.; Sato, M.; Goldman, M.; Ransone, L.; Sponner, C. Bioorg. Med. Chem. Lett. 2002, 12, 2573.

36. (a) Ishihara, T.; Maekawa, T.; Ando, T. Tetrahedron Lett. 1983, 24, 4229. (b) Huang, W. S.; Yuan, C. Y. J. Chem. Soc., Perkin Trans. 1 1995, 741. (c) Palacios, F.; Pascual, S.; Oyarzabal, J.; de Retana, A. M. O. Org. Lett. 2002, 4, 769. (d) Palacios, F.; Oyarzabal, J.; de Retana, A. M. O.; Pascual, S.; Oyarzabal, J. J. Org. Chem. 2004, 69, 8767.

37. (a) Yoshimatsu, M.; Sugimoto, T.; Okada, N.; Kinoshita, S. J. Org. Chem. 1999, 64, 5162. (b) Matsubara, Y.; Yoshimatsu, M. J. Org. Chem. 2000, 65, 4456. (c) Yoshimatsu, M.; Timura, Y. J. Org. Chem. 2002, 67, 5678.

38. Jiang, B. Chem. Comm. 1996, 861.

39. Peng, W.; Zhu, S. Tetrahedron 2003, 59, 4641.

40. (a) Pashkevich, K. I.; Khomutov, O. G.; Sevenard, D. V. Russ. Chem. Bull. 1999, 48, 557. (b) Venkat Reddy, G.; Rama Rao, V. V. V. N. S.; Maitraie, D.; Ravikanth, S.; Yadla, R.; Reddy, S. N.; Narsaiah, B.; Shanthan Rao, P. J. Fluorine. Chem. 2003, 124, 203. (c) Yachevskii, D. S.; Chizhov, D. L.; Kodess, M. I.; Pashkevich, K. I. Monatsch. Chem. 2004, 135, 23.

41. (a) Pashkevich, K. I.; Khomutov, O. G.; Sevenard, D. V. Russ. J. Org. Chem. 1998, 34, 1727.

(b) Bartoli, G.; Bosco, M.; Locatelli, M.; Marcantoni, E.; Melchiorre, P.; Sambri, L. Synlett 2004, 239.

42. (a) Pashkevich, K.; Aizikovich, A. Izv. Akad. Nauk SSSR, Ser. Khim. 1982, 1908. (b) Pashkevich, K. I.; Bobrov, M. B.; Aizikovich, A. Ya.; Rudaya, M. N. Izv. Akad. Nauk SSSR, Ser. Khim. 1986, 2125. (c) Bayer, E.; Mueller, H. P.; Sievers, R. Anal. Chem. 1971, 43, 2012. (d) Bartnik, R.; Bensadat, A.; Cal, D.; Cebulska, Z.; Laurent, A.; Laurent, E.; Rizzon, C. Tetrahedron Lett. 1996, 37, 8751. (e) Alvernhe, G.; Bensadat, A.; Ghobsi, A.; Laurent, A.; Laurent, E. J. Fluorine Chem. 1997 81, 169.

43. (a) Zanatta, N.; Squizani, A. M. C.; Fantinel, L.; Nachtigall, F. M.; Bonacorso, H. G.; Martins, M. A. P. Synthesis 2002, 2409. (b) Zhu, S.; Chu, Q.; Wang, Y. Heteroatom Chem. 2000, 11, 27. 44. Zhu, S.; Xu, G.; Qin, C.; Chu, Q.; Xu, Y. Monatsh. Chem. 1999, 130, 671. 
45. Cebulska, Z.; Laurent, A. J.; Laurent, E. G. J. Fluorine Chem. 1996, 76, 177.

46. Gorbunova, M. G.; Gerus, I. I.; Kukhar, V. P. J. Fluorine Chem. 1993, 25.

47. Sanin, A. V.; Nenajdenko, V. G.; Smolko, K I.; Denisenko, D. I.; Balenkova, E. S. Synthesis 1998, 842.

48. (a) Sanin, A. V.; Nenaidenko, V. G.; Denisenko, D. I.; Smolko, K. I.; Balenkova, E. S. Russ. J. Org. Chem. 1999, 35, 209. (b) Martins, M. A. P.; Emmerich, D. J.; Pereira, C. M. P.; Cunico, W.; Rossato, M.; Zanatta, N.; Bonacorso, H. Terahedron Lett. 2004, 45, 4935.

49. Koldobskii, A. B.; Tsvetkov, N. P.; Solodova, E. V.; Verteletskii, P. V. Godovikov, I. A.; Kalinin, V. N. Tetrahedron 2010, 66, 3457.

50. Koldobskii, A. B.; Tsvetkov, N. P.; Kalinin, V. N. Doklady Chemistry 2010, 432, 133.

51. Mo, X-S.; Huang, Y-Z. Synlett 1995, 180.

52. (a) Hara, S.; Kato, N.; Takada, E.; Suzuki, A. Synlett 1994, 961. (b) Takada, E.; Hara, S.; Suzuki, A. Heteroatom. Chem. 1992, 483.

53. Matsumoto, N.; Takahashi, M. Tetrahedron Lett. 2005, 46, 5551.

54. (a) Krasovsky, A.; Nenajdenko, V.; Balenkova, E. Russ. Chem. Bull. 2002, 51, 2080. (b) Krasovsky, A.; Pissarev, S.; Nenajdenko, V. G.; Balenkova E. S. J. Chem. Soc. Perkin. Trans. 1 2002, 2554. (c) Krasovsky, A. L.; Nenajdenko, V. G.; Balenkova, E. S. Tetrahedron 2001, 57, 201. (d) Nenajdenko, V. G.; Krasovsky, A. L.; Balenkova, E. S. Tetrahedron 2007, 63, 12481.

55. (a) Krasovsky, A. L.; Moiseev, A. M.; Nenajdenko, V. G.; Balenkova, E. S. Khim. Het. Soed. 2004, 784. (b) Krasovsky, A. L.; Nenajdenko, V. G.; Balenkova, E. S. Russ. Chem. Bull. 2001, $50,1395$.

56. (a) Nenajdenko, V. G.; Krasovsky, A. L.; Lebedev, M. V.; Balenkova, E. S. Synlett 1997, 1349.

(b) Krasovsky, A.; Pisarev, S.; Nenajdenko, V.; Balenkova, E. Russ. Chem. Bull. 2003, 1791.

57. Krasovsky, A.; Druzhinin, S.; Nenajdenko, V.; Balenkova, E. Tetrahedron Lett. 2004, 45, 1129.

58. Funabiki, K.; Ohtsuki, T.; Ishira, T.; Yamanaka, H. J. Chem. Soc. Perkin Trans. 1 1998, 2413.

59. Yang, X. -J.; Liu, J. -T.; Zhao, F. -L. J. Fluorine Chem. 2004, 125, 415.

60. (a) Gerus, I. I.; Gorbunova, M. G.; Vdovenko, S. I.; Yagupol'skii, Yu. L.; Kukhar', V. P. Zh. Org. Khim. 1990, 26, 1877. (b) Hojo, M.; Masuda, R.; Okada, E. Tetrahedron Lett. 1989, 30, 6173. (c) Pashkevich, K. I.; Filyakova, V. I. Izv. Akad. Nauk SSSR, Ser. Khim. 1986, 620.

61. Stefani, H. A.; Pereire, C. M. P.; Doerr, F. A.; Cella, R. Arkivoc 2005, (vi), 19.

62. Martins, M. A. P.; Bastos, G. P.; Sinhorin, A. P.; Zimmermann, N. E. K.; Bonacorso, H. G.; Zanatta, N.; Synthesis 2002, 2220.

63. (a) Gerus, I. I.; Kruchok, I. S.; Kukhar, V. P. Tetrahedron Lett. 1999, 40, 5923. (b) Kruchok, I. S.; Gerus, I. I.; Kukhar, V. P. Synthesis 2002, 71. (c) Kruchok, I. S.; Gerus, I. I.; Kukhar, V. P. Tetrahedron 2000, 56, 6533.

64. (a) Gerus, I. I.; Kacharova, L. M.; Vdovenko, S. I. Synthesis 2001, 431. (b) Kacharova, L. M.; Kacharov, A. D.; Gerus, I I. J. Fluorine. Chem. 2001, 111, 29. (c) Reznikov, V. A.; Skuridin, N. G.; Khromovskikh, E. L.; Khramtsov, V. V. Russ. Chem. Bull. 2003, 52, 2052. (d) Rulev, A. Yu.; Fedorov, S. V.; Nenajdenko, V. G.; Balenkova, E. S.; Voronkov, M. G. Russ. Chem. Bull. 2003, 52, 2287. (e) Fedorov, S. V.; Rulev, A. Yu.; Chipanina, N. N.; Shulunova, A. M.; Nenajdenko, V. G.; Balenkova, E. S.; Tyurin, D. A.; Turchaninov, V. K. Russ. Chem. Bull. 
2005, 54, 103. (f) Rulev, A. Yu.; Ushakov, I. A., Nenajdenko, V. G. Tetrahedron 2008, 64, 8073. (g) Rulev, A. Yu.; Ushakov, I. A., Nenajdenko, V. G.; Balenkova, E. S.; Voronkov, M. G. Eur. J. Org. Chem. 2007, 6039.

65. (a) Lyutenko, N. V.; Gerus, I. I.; Kacharov, A. D.; Kukhar, V. P. Tetrahedron 2003, 59, 1731.

(b) Gerus, I. I.; Lyutenko, N. V.; Kacharov, A. D.; Kukhar, V. P. Tetrahedron Lett 2000, 41, 10141.

66. Rosa, F. A.; Machado, P.; Rossatto, M.; Vargas, P. S.; Bonacorso, H. G.; Zanatta, N.; Martins, M. A. P. Synlett 2007, 20, 3165.

67. Ferrer, L. O.; Margaretha, P. Chem. Comm. 2001, 481.

68. (a) Linderman, R. J.; Jamois, E. A.; Tennyson, S. D. J. Org. Chem. 1994, 59, 957. (b) Linderman, R. J.; Graves D. M. J. Org. Chem. 1989, 54, 661. (c) Hanzawa, Y.; Yamada, A.; Kobayashi, Y. Tetrahedron Lett. 1985, 26, 2881.

69. Singh, R. P.; Cao, G.; Kirchmeier, R. L.; Shreeve, J. M. J. Org. Chem. 1999, 64, 2873.

70. Kremlev, M. M; Mushta, A. I.; Tyrra, W.; Naumann, D.; Hendrik, T. M.; Yagupolskii, Y. L. J. Fluorine Chem. 2007, 128, 1385.

71. (a) Hegde, V. B.; Renga, J. M.; Owen, J. M. Tetrahedron Lett. 2001, 42, 1847. (b) Jones, B. G.; Branch, S. K.; Thompson, A. S.; Threadgill, M. D. J. Chem. Soc. Perkin Trans 1 1996, 2685. (c) Frey, R. R.; Wada, C. K.; Garland, R. B.; Curtin, M. L.; Michaelides, M. R.; Li, J.; Pease, L. J.; Glaser, K. B.; Marcotte, P. A.; Bouska, J. J.; Murphy, S. S.; Davidsen, S. K. Bioorg. Med. Chem. Lett. 2002, 12, 3443. (d) Koldobskii, A. B.; Solodova, E. V.; Kalinin, V. N. Dokladi Chemistry 1999, 366, 110.

72. Obrecht, D.; Gerber, F.; Sprenger, D.; Masquelin, T. Helv. Chim. Acta. 1997, 80, 531.

73. Ishizaki, M.; Suzuki, D.; Hoshino, O. J. Fluorine Chem. 2001, 81.

74. (a) Tsvetkov, N. P.; Koldobskii, A. B.; Kalinin, V. N. Dokladi Chemistry 2005, 404, 174. (b) Tsvetkov, N. P.; Koldobskii, A. B.; Korznikova, I. V.; Peregudov, A. S.; Kalinin, V. N. Doklady Chemistry 2006, 408, 87. (c) Tsvetkov, N. P.; Koldobskii, A. B.; Godovikov, I. A. Kalinin, V. N. Dokladi Chemistry 2005, 404, 210.

75. (a) Linderman, R. J.; Lonikar, M. S. J. Org. Chem. 1988, 53, 6013. (b) Linderman, R. J.; Lonikar, M. S. Tetrahedron Lett. 1987, 28, 5271.

76. Linderman, R. J.; Kirollos, K. S. Tetrahedron Lett. 1990, 31, 2689.

77. Coe, P. L.; Owen, I. R.; Till, S. J. J. Chem Soc. Perkin Trans. 1 2000, 1529.

78. Martins, M. A. P.; Pereira, C. M. P.; Zimmermann, N. E. K.; Cunico, W.; Moura, S.; Beck, P.; Zanatta, N.; Bonacorso, H. G. J. Fluorine Chem. 2003, 123, 261.

79. Nenaidenko, V. G.; Druzhinin, S. V.; Balenkova, E. S. Russ. Chem. Bull. 2003, 52, 2467.

80. (a) Lee, H.; Kim, K. Tetrahedron Lett. 1998, 39, 5781. (b) Lee, H. -S.; Kim, K. Tetrahedron Lett. 1998, 39, 6895.

81. Cebulska, Z.; Laurent, A. J.; Laurent, E. G. Bull. Chim. France 1996, 133, 209.

82. Krasnykh, O. P.; Karpenko, N. S. Filyakova, V. I.; Charushin, V. N. Russ. Chem. Bull. 2004, 53, 1355.

83. Zanatta, N.; Schneider, J. M. F.; Schneider, P. H.; Wouters, A. D.; Bonacorso, H. G.; Martins, M. A. P.; Wessjohann, L. A. J. Org. Chem. 2006, 71, 6996. 
84. (a) Andrew, R. J.; Mellor, J. M. Tetrahedron, 2000, 56, 7267. (b) Soufyane, M.; Mirand, C.; Le'vy, J. Tetrahedron Lett. 1993, 34, 7737.

85. (a) Okada, E.; Masuda, R.; Hojo, M.; Inoue, R. Synthesis, 1992, 533. (b) Okada, E.; Masuda, R.; Hojo, M.; Yoshida, R. Heterocycles 1992, 34, 1435.

86. Hernandez-Toribio, J.; Arrayas, R. G.; Martın-Matute, B.; Carretero J. C. Org. Lett. 2009, 11, 393.

87. Zanatta, N.; Wouters, A. D.; Fantinel, L.; da Silva, F. M.; Barichello, R.; da Silva, P. E. A.; Ramos, D. F.; Bonacorso, H. G.; Martins, M. A. P. Synlett 2009, 755.

88. Müller, J.; Troschütz, R.; Synthesis 2006, 1513.

89. (a) Rudenko, A. P.; Aristov, S. A.; Vasilyev, A. V. Russ. J. Org. Chem. 2004, 40, 1221. (b) Aristov, S. A.; Vasilyev, A. V.; Rudenko, A. P. Russ. J. Org. Chem. 2006, 42, 66.

90. Avetisyan, E. A.; Gambaryan, N. P. Izv. Akad. Nauk SSSR, Ser. Khim. 1973, 2559.

91. Zhang, D. H. Yuan, C. Y. Eur. J. Org. Chem. 2007, 3916.

92. Bartnik, R.; Bensadat, A.; Cal, D.; Faure, R. Khatimi, N.; Laurent, A.; Laurent, E.; Rizzon, C. Bull. Soc. Chim. Fr. 1997, 134, 725.

93. (a) Touzot, A.; Soufyane, M.; Berber, H.; Toupet, L.; Mirand, C. J. Fluorine. Chem. 2004, 125, 1299. (b) Pashkevich, K. I.; Filyakova, V. I.; Kuznetsova, O. A. Russ. Chem. Bull. 1996, 45 , 2868.

94. (a) Braibante, M. E. F.; Clar, G.; Martins, M. A. P J. Het. Chem. 1993, 30, 1159. (b) Pavlik, J. W.; Ayudhya, T. I. N.; Tantaynon, S. J. Het. Chem. 2002, 39, 1025. (c) Schlosser, M.; Volle, J. N.; Leroux, F.; Schenk, K. Eur. J. Org. Chem. 2002, 2913. (d) Pavlik, J. W.; Ayudhya, T. I. N.; Tantaynon, S. J. Het. Chem. 2003, 40, 1087.

95. Martins, M. A. P.; Bastos, G. P.; Sinhorin, A. P.; Zimmermann, N. E. K.; Rosa, A.; Brondani, S.; Emmerich, D.; Bonacorso, H. G., Zanatta, N. J. Fluorine Chem. 2003, 123, 249.

96. (a) Bonacorso, H. G.; Cechinel C. A.; Oliveira, M. R.; Costa, M. B.; Martins, M. A. P.; Zanatta, N.; Flores, A. F. C. J. Het. Chem. 2005, 42, 1055. (b) Cunico, W.; Cleber, A.; Cechinel, A.; Bonacorso, H. G.; Martins, M. A. P.; Zanatta, N.; de Souza, M. V. N.; Fraitas, I. O.; Soares, R. P. P.; Kretti, A. U. Bioorg. Med. Chem. Lett. 2006, 16, 649. (c) Zanatta, N.; Flores, D. C.; Madruga, C. C.; Faoro, D.; Flores, A. F. C.; Bonacorso, H. G.; Martins, M. A. P. Synthesis 2003, 894. (d) Sauzem, P. D.; Machado, P.; Rubin, M. A.; Sant'Anna, G. da S.; Faber, H. B.; de Souza, A. H.; Mello, C. F.; Beck, P.; Burrow, R. A. Bonacorso, H. G.; Zanatta, N.; Martins, M. A. P. Eur. J. Med. Chem. 2008, 43, 1237 . (e) Bonacorso, H. G.; Wentz, A. P.; Lourega, R. V.; Cechinel, C. A.; Moraes, T. S.; Coelho, H. S.; Zanatta, N.; Martins, M. A. P.; Hoerner, M.; Alves, S. H. J. Fluor. Chem. 2006, 127, 1066. (f) Reddy, M. V. R.; Billa, V. K.; Pallela, V. R.; Mallireddigari, M. R.; Boominathan, R.; Gabriel, J. L.; Reddy, E. P. Bioorg. Med. Chem. 2008, 3907.

97. Singh, S. P.; Kumar, D.; J. Chem. Res. 1997, 142.

98. (a) Song, L. -P.; Chu, Q. -L.; Zhu, S. -Z. J. Fluorine Chem. 2001, 107, 107. (b) Bonacorso, H. G.; Porte, L. M. F.; Cechinel, C. A.; Paim, G. R.; Deon, E. D.; Zanatta, N.; Martins M. A. P. Tetrahedron Lett. 2009, 50, 1392. 
99. Martins, M. A. P.; Cunico, W.; Brondani, S.; Peres, R. L.; Zimmerman, N.; Rosa, F. A.; Fiss, G. F.; Zanatta, N.; Bonacorso, H. G. Synthesis 2006, 1485.

100. Nenajdenko, V. G.; Reznichenko, A. L.; Balenkova, E. S. Russ. Chem. Bull. 2006, 1, 172.

101. (a) Levskovskaya, G. G.; Bozhenkov, G. V.; Larina, L. I.; Mirskova, A. N. Russ. J. Org. Chem. 2002, 38, 1501. (b) Bozhenkov, G. V.; Levskovskaya, G. G.; Mirskova, A. N.; Dolgushin, G. V.; Larina, L. I.; Ushakov, P. E. Russ. J. Org. Chem. 2003, 39, 1069. (c) Bozhenkov, G. V.; Frolov, Yu. L.; Toryashinova, D. S. -D.; Levskovskaya, G. G.; Mirskova Russ. J. Org. Chem. 2003, 39, 807. (d) Bozhenkov, G. V.; Savosik, V. A.; Larina, L. I.; Klyba, L. V.; Zhanchipova E. R. Mirskova, A. N.; Levskovskaya, G. G. Russ. J. Org. Chem. 2003, 39, 1024.

102. Martins, M. A. P.; Blanco, R. F.; Pereira, C. M. P.; Beck, P.; Brondani, S.; Cunico, W.; Zimmermann, N. E. K.; Bonacorso, H. G.; Zanatta, N. J. Fluorine Chem. 2002, 118, 69.

103. Kawase, M.; Hyrabayashi, M.; Saito, S.; Yamamoto, K. Tetrahedron Lett. 1999, 40, 2541.

104. Mellor, J. M.; Schofield, S. R.; Korn, S. R. Tetrahedron 1997, 53, 17163.

105. Moreira, D. N.; Frizzo, C. P.; Longhi, K. Zanatta, N.; Bonacorso, H. G.; Martins M. A. P. Monatsh. Chem. 2008, 1049.

106. Bonacorso, H. G.; Wentz, A. P.; Zanatta, N.; Martins, M. A. P. Synthesis 2001, 1505.

107. Bonacorso, H. G.; Wastowski, A. D.; Zanatta, N.; Martins, M. A. P.; Naue, J. A. J. Fluorine. Chem. 1998, 92, 23.

108. Martins, M. A. P.; Sinhorin, A. P.; da Rosa, A.; Flores, A. F. C.; Wastowski, A. D.; Pereira, C. M. P.; Flores, D. C.; Beck, P.; Freitag, R. A.; Brondani, S.; Cunico, W.; Bonacorso, H. G.; Zanatta, N. Synthesis 2002, 2353.

109. (a) Bonacorso, H. G.; Lewandrowski, H.; Drekener, R. L.; Costa, M. B.; Pereira, C. M. P.; Wastowski, A. D.; Peppe, C.; Martins, M. A. P.; Zanatta, N. J. Fluorine Chem. 2003, 122, 159. (b) Bonacorso, H. G.; Lang, E. S.; Lewandowski, H.; Martins, M. A. P.; Peppe, C.; Zanatta, N. Inorg. Chem. Comm. 2003, 6, 646.

110. (a) Nenajdenko, V. G.; Sanin, A. V.; Balenkova, E. S. Zh. Org. Khim. 1995, 31, 786. (b) Pryadeina, M. V.; Burgart, Ya. V.; Kodess, M. I.; Saloutin, V. I.; Chupakhin, O. N. Russ. Chem. Bull. 2004, 53, 1261.

111. Gambaryan, N. P.; Simonyan, L. A.; Petrovskii, P. V. Izv. Akad. Nauk SSSR, Ser. Khim. 1967, 918.

112. Sanin, A. V.; Nenajdenko, V. G.; Kuz'min, V. S.; Balenkova, E. S. Khim. Geterotsikl. Soedin. 1998, 634.

113. Linderman, R. J.; Kirollos, K. S. Tetrahedron Lett. 1989, 30, 2049.

114. Kamitori, Y.; Hojo, M.; Masuda, R.; J. Het. Chem. 1993, 30, 389.

115. Nenajdenko, V. G.; Statsuk, A. V.; Balenkova, E. S. Chem. Het. Comp. 2003, 5, 598.

116. Trofimov, B. A.; Schmidt, E. Yu.; Mikhaleva, A. I.; Vasil’tsov, A. M.; Larina, L. I.; Klyba, L. V. Mend. Comm. 1999, 6, 238.

117. (a) Martins, M. A. P.; Machado, P.; Piovesan, L. A.; Flores, A. F. C.; de Campos, M. M. A.; Scheidt, C.; Bonacorso, H. G.; Zanatta N. Monatsh. Chem. 2008, 139, 985. (b) Martins, M. A. P.; Siqueira, G. M.; Bastos, G. P.; Bonacorso, H. G.; Zanatta, N. J. Het. Chem. 1996, 33, 1619. 
(c) Flores, A. F. C.; Brondani, S.; Pizutti, L.; Martins, M. A. P.; Zanatta, N.; Bonacorso, H. G. Synthesis 2005, 2744.

118. Okada, E.; Okumura, H.; Nishida, Y.; Kitahora, T. Heterocycles 1999, 50, 377.

119. Martins, M. A. P.; Flores, A. F. C.; Bastos, G. P.; Zanatta, N.; Bonacorso, H. G. J. Het. Chem. 1999, 36, 837.

120. Jiang, H.; Yue, W.; Xiao, H.; Zhu S. Tetrahedron 2007, 63, 2315.

121. Zhu, S.; Jin, G.; Peng, W.; Huang, Q. Tetrahedron 2003, 59, 2899.

122. Majo, V. J.; Prabhakaran, J.; Simpson, N. R.; Van Heertum, R. L.; Mann, J. J.; Dileep Kumar, J. S. Bioorg. Med. Chem. Lett. 2005, 15, 4268.

123. (a) Soloshonok, V. A.; Kacharov, A. D.; Avilov, D. V. Tetrahedron Lett. 1996, 43, 7845. (b) Soloshonok, V. A.; Kacharov, A. D.; Avilov, D. V.; Ishikawa, K.; Nagashima, N.; Hayashi, T. J. Org. Chem. 1997, 62, 3470. (c) Gulevich, A. V., Zhdanko, A. G.; Orru, R.; Nenajdenko, V. Chem. Rev. 2010, 5425.

124. Colantoni, D.; Fioravanti, S.; Pellacani, L.; Tardella P. A. J. Org. Chem. 2006, 6295.

125. Peng, W. -M.; Zhu, S. -Z. J. Fluorine Chem. 2002, 116, 81.

126. Cooke, J. W. B.; Coleman, M. J.; Caine, D. M.; Jenkins, K. P. Tetrahedron Lett. 1998, 39, 7965.

127. Cocco, M. T.; Congiu, C.; Onnis, V.; Morelli, M.; Felipo, V.; Cauli, O. Bioorg. Med. Chem. Lett. 2004, 12, 4169.

128. Katsuyama, I.; Ogava, S.; Yamaguchi, Y.; Funabiki, K.; Matsui, M.; Muramatsu, H.; Shibata, K. Synthesis 1997, 1321.

129. Cocco, M. T.; Congiu, C.; Onnis, V. J. Het. Chem. 1996, 33, 1771.

130. Palacios, F.; Ochoa de Retana, A. M.; Oyarzabal, J.; Pascual, S.; Fernandez de Troconiz G. J. Org. Chem. 2008, 73, 4568.

131. (a) Cocco, M. T.; Congiu, C.; Onnis, V. Terahedron Lett. 1999, 40, 4407. (b) Cocco, M. T.; Congiu, C.; Onnis, V. Chem. Pharm. Bull. 2001, 49, 703. (c) Cocco, M. T.; Congiu, C.; Lilliu, V.; Onnis, V. Bioorg. Med. Chem. Lett. 2004, 14, 5787. (d) Cocco, M. T.; Congiu, C.; Lilliu, V.; Onnis, V. J. Med. Chem. 2005, 48, 8245.

132. Katsuyama, I.; Funabiki, K.; Matsui, M.; Muramatsu, H.; Shibata, K. Tetrahedron Lett. 1996, 37, 4177.

133. Carroll, W. A.; Altenbach, R. J.; Bai, H.; Brioni, J. D.; Brune, M. E.; Buckner, Ste. A.; Cassidy, C.; Chen, Y.; Coghlan, M. J.; Daza, A. V.; Drizin, I.; Fey, T. A.; Fitzgerald, M.; Gopalakrishnan, M.; Gregg, R. J.; Henry, R. F.; Holladay. M. W.; King, L. L.; Kort, M. E.; Kym, P. R.; Milicic, I.; Tang, R.; Turner, S. C.; Whiteaker, K. L.; Yi, L.; Zhang, H.; Sullivan, J. P. J. Med. Chem. 2004, 47, 3163.

134. (a) Konakahara, T.; Hojahmat, M.; Tamura, S. J. Chem. Soc. Perkin Trans. 1 1999, 2803. (b) Konakahara, T.; Sugama, N.; Yamada, A.; Kakehi, A.; Sakai, N. Heterocycles 2001, 55, 313. (c) Hojahmat, M.; Konakahara, T.; Tamura, S. Heterocycles 2000, 53, 629.

135. (a) Okada, E.; Kinomura, T.; Higashiyama, Y.; Takeuchi, H.; Hojo, M. Heterocycles 1997, 44, 129. (b) Lahm, G. P.; Selby, T. P.; Freudenberger, J. H.; Stevenson, T. M.; Myers, B. J.; Seburyamo, G.; Smith, B. K.; Flexner, L.; Clark, C. E.; Cordova, D. Bioorg. Med. Chem. Lett. 
2005, 15, 4898. (c) Isaacs, R. C. A.; Cutrona, K. J.; Newton, C. L.; Sanderson, P. E.; Solinski, M. G.; Baskin, E. P.; Chen, I-Wu.; Cooper, C. M.; Cook, J. J.; Cardell, S. J.; Lews, S. D.; Lucas Jr., R. J.; Lyle, E. A.; Lynch Jr., J. J.; Naylor-Olsen, A. M.; Stranieri, M. T.; Vastag, K.; Vacca, J. P. Bioorg. Med. Chem. Lett. 1998, 8, 1719. (d) Zanatta, N.; Barichello, R.; Bonacorso, H. G.; Martins, M. A. P. Synthesis 1999, 765.

136. Funabiki, K.; Isomura, A.; Yamaguchi, Y.; Hashimoto, W.; Matsumaga, K.; Shibata, K.; Matsui, M. J. Chem. Soc. Perkin Trans. 1 2001, 2578.

137. Sanin, A. V.; Nenajdenko, V. G.; Krasovskii, A. L.; Churakov, A. V.; Howard, J. A. K.; Balenkova, E. S. Rus. J. Org. Chem. 1997, 33, 205.

138. (a) Kislyi, V. P.; Nikishin, K. G.; Kruglova, E. Ya.; Shestopalov, A. M.; Semenov, V. V. Terahedron 1996, 33, 10841. (b) Yakunin, Ya. Yu.; Dyachenko, V. D.; Litvinov, V. P. Chem. Het. Comp. 2000, 36, 1431. (c) Dyachenko, V. D.; Tkachev, R. P.; Dyachenko, A. D. Rus. J. Org. Chem. 2009, 121.

139. Nenajdenko, V. G.; Druzhinin, S. V.; Balenkova, E. S. J. Fluorine Chem. 2006, 127, 856.

140. (a) Xiong, W. -N.; Yang, C. -G.; Jiang, B. Bioorg. Med. Chem. Lett. 2001, 9, 1773. (b) Jiang, B.; Xiong, W.; Zhang, X.; Zhang, F. Org. Proc. Res. Dev. 2001, 5, 531.

141. Amii, H.; Kobayashi, T.; Terasawa, H.; Uneyama, K. Org. Lett. 2001, 3, 3103.

142. Zanatta, N.; Fernandes, L. S.; Nachtigall, F. M.; Coelho, H. S.; Amaral, S. S.; Flores, A. F. C.; Bonacorso, H. G.; Martins M. A. P. Eur. J. Org. Chem. 2009, 1435.

143. (a) Gerus, I. I.; Kropachev, A. V.; Gorbunova, M. G.; Il'chenko, A. Ya.; Kukhar', V. P. Ukr. Khim. Zh. 1993, 59, 408. (b) Schlosser, M.; Keller, H.; Sumida, S.; Yang, J. Tetrahedron Lett. 1997, 38, 8523.

144. Dade, J.; Provot, O.; Moskowitz, H.; Mayrargue, J.; Prina, E. Chem. Pharm. Bull. 2001, 49, 480.

145. (a) Boltacheva, N. S.; Filyakova, V. I.; Charushin, V. N. Russ. Chem. Bull. 2005, 41, 1452.

(b) Bonacorso, H. G.; Duarte, S. H. G.; Zanatta, N.; Martins, M. A. P. Synthesis 2002, 1037.

146. Bonacorso, H. G.; Drekener, R. L.; Rodrigues, I. R.; Vezzosi, R. P.; Costa, M. B.; Martins, M. A. P.; Zanatta, N. J. Fluorine Chem. 2005, 126, 1384.

147. Baraznenok, I. L.; Nenajdenko, V. G.; Balenkova, E. S. Eur. J. Org. Chem. 1999, 937.

148. Masquelin, T.; Obrecht, D. Tetrahedron 1997, 53, 641.

149. (a) Tordeux, M.; Wakselman, C. J. Fluorine Chem. 1982, 20, 301. (b) Krasovsky, A. L.; Nenajdenko, V. G.; Balenkova, E. S. Russ. Chem. Bull. 2002, 51, 609.

150. Zhao, Y.; Wang, X.; Liu J. Synlett 2008, 1017.

151. (a) Hayman, C. M.; Larsen, D. S.; Brooker, S. Aust. J. Chem. 1998, 51, 545. (b) Hayman, C.

M.; Hanton, L. R.; Larsen, D. S.; Guthrie, J. M. Aust. J. Chem. 1999, 52, 921.

152. Hojo, M.; Masuda, R.; Okada, E. Synthesis 1990, 347.

153. Hojo, M.; Masuda, R.; Okada, E. Synthesis 1989, 215.

154. Kondratov, I. S.; Gerus, I. I.; Kukhar, V. P.; Manoilenko, O. V. Tetrahedron Asymm. 2007, $18,1918$.

155. Nenajdenko, V. G.; Druzhinin, S. V.; Balenkova, E. S. Mend. Comm. 2006, 16, 180. 
156. Nenajdenko, V. G.; Sanin, A. V.; Churakov, A. V.; Howard, J. A. K.; Balenkova, E. S. Chem. Het. Comp. 1999, 35, 549.

157. Sanin, A. V.; Nenajdenko, V. G.; Kuz'min, V. S.; Balenkova, E. S. J. Org. Chem. 1996, 61, 1986.

158. Chu, Q.; Song, L.; Jin, G.; Zhu, S. J. Fluorine Chem. 2001, 108, 51.

159. Jiang, H.; Zhu, S. Synlett 2006, 1343.

160. Chizhov, D.; Sosnovskikh, V.; Pryadeina, M. V.; Burgart, Y. V.; Saloutin, V. I., Charushin, V. N. Synlett 2008, 281.

161. Bunescu, A.; Reimann, S.; Lubbe, M.; Spannenberg, A.; Langer P. J. Org. Chem. 2009, 74, 5002.

162. (a) Gerus, I. I.; Tolmacheva, N. A.; Vdovenko, S. I.; Frohlich, R.; Haufe, G. Synthesis 2005, 1269. (b) Tolmacheva, N. A.; Gerus, I. I.; Vdovenko, S. I.; Haufe, G.; Kirzhner Y. A. Synthesis 2007, 3797.

163. (a) Gerus, I. I.; Vdovenko, S. I.; Gorbunova, M. G.; Kukhar', V. P. Khim. Geterotsikl. Soedin. 1991, 502. (b) Bonacorso, H. G.; Lopes, I. S.; Wastowski, A. D.; Zanatta, N.; Martins, M. A. P. J. Fluorine Chem. 2003, 120, 29.

164. Ondi, L.; Lefebvre, O.; Schlosser, M. Eur. J. Org. Chem. 2004, 3714.

165. Nenajdenko, V. G.; Sanin, A. V.; Kuz'min, V. S.; Balenkova, E. S. Zh. Org. Khim. 1996, 32, 1579.

166. Bonacorso, H. G.; Costa, M. B.; Lopes, I. S.; Oliveira, M. R.; Drekener, R. L.; Martins, M. A. P.; Zanatta, N.; Flores, A. F. C. Synth. Comm. 2005, 35, 3055.

167. Zanatta, N.; Fagundes, M. B.; Ellensohn, R.; Marcues, M.; Bonacorso, H. G.; Martins, M. A. P. J. Het. Chem. 1998 35, 451.

168. (a) Funabiki, K.; Nakamura, H.; Matsui, M.; Shibata, K. Synlett 1999, 756. (b) Palanki, M. S. S.; Erdman, P. E.; Gayo-Fung, L. M.; Shevlin, G. I.; Sullivan, R. W.; Suto, M. J.; Goldman, M. E.; Ransone, L. J.; Brydon, B. L.; Manning, A. M. J. Med. Chem. 2000, 43, 3995. (c) Soufyane, M.; van den Brock, S.; Khamliche, L.; Mirand, C. Heterocycles 1999, 10, 2445.

169. Bonacorso, H. G.; Ferla, A.; Cechinel, C. A.; Zanatta, N.; Martins M. A. P. J. Het. Chem., 2008, $45,483$.

170. Zanatta, N.; Amaral, S. S.; dos Santos, J. M.; de Mello, D. L.; Fernandes, L. S.; Bonacorso,

H. G.; Martins, M. A. P.; Andricopulo, A. D.; Borchhardt, D. M. Bioorg. Med. Chem. 2008, 10236.

171. Zanatta, N.; Faoro, D.; Fernandes, L.; Brondani, P. B.; Flores, D. C.; Flores, A. F. C.; Bonacorso, H. G.; Martins, M. A. P. Eur. J. Org. Chem. 2008, 5832.

172. (a) Zanatta, N.; Madruga, C. C.; Marisco, P. C.; da Rosa, L. S.; Fernandes, L. S.; Flores, D. C.; Flores, A. F. C.; Burrow, R. A.; Bonacorso, H. G.; Martins, M. A. P. J. Het. Chem. 2008, 45, 221. (b) Madruga, C. C.; Clerici, E.; Martins, M. A. P.; Zanatta, N. J. Het. Chem. 1995, 32, 735.

173. Zanatta, N.; de C. Madruga, C.; da C. Marisco, P.; Florres, D. C.; Bonacorso, H. G.; Martins, M. A. P. J. Het. Chem. 2000, 37, 1213. 
174. Dorigo, P.; Fraccarollo, D.; Santostasi, G.; Marango, I.; Floreani, M.; Borea, P. A.; Mosti, L.; Sansebastiano, L.; Fossa, P.; Orsini, F.; Benetollo, F.; Bombrieri, G. J. Med. Chem. 1996, $39,3671$.

175. Berber, H.; Soufyane, M.; Santillana-Hayat, M.; Miranda, C. Tetrahedron Lett. 2002, 43, 9233.

176. Cechin, S. R.; Schetinger, M. R. C.; Zanatta, N.; Madruga, C. C.; Pacholski, I. L.; Flores, D.

C.; Bonacorso, H. G.; Martins, M. A. P.; Morsch, V. M. Chem. Res. Toxicol. 2003, 16, 1433.

177. Zanatta, N.; Lopes, E. C. S.; Fantinel, L.; Bonacorso, H. G.; Martins, M. A. P. J. Het. Chem. 2002, 39, 943.

178. Okada, E.; Kinomura, T.; Takeuchi, H.; Hojo, M. Heterocycles 1997, 44, 349.

179. Zhao, F. -L.; Liu. J. -T.; J. Fluorine Chem. 2004, 125, 1491.

180. Bonacorso, H. G.; Martins, D. B.; Martins, M. A. P.; Zanatta, N.; Flores, A. F. C. Synthesis 2005, 809.

181. Flores, D. C.; Fiss, G. F.; Wbatuba, L. S.; Martins, M. A. P.; Burrow, R. A.; Flores, A. F. C. Synthesis 2006, 2349.

182. (a) Bonacorso, H. G.; Bittencourt, S. R. T.; Lourega, R. V.; Flores, A. F. C.; Zanatta, N.; Martins, M. A. P. Synthesis 2000, 1431. (b) Bonacorso, H. G.; Vezzosi, R. P.; Rodrigues, I. R.; Drekener, R. L.; Porte, L. M. F.; Flores, A. F. C.; Zanatta, N.; Martins, M. A. P. J. Braz. Chem. Soc. 2009, 1370. (c) Bonacorso, H. G.; Vezzosi, R. P.; Drekener, R. L.; Zanatta, N.; Martins, M. A. P. Lett. Org. Chem. 2009, 6, 145.

183. Nenajdenko, V. G.; Sanin, A. V.; Lebedev, M. V.; Balenkova, E. S. Zh. Org. Khim. 1995, $31,783$.

184. Zanatta, N; Borchhardt, D. M.; Alves, S. H.; Coelho, H. S.; Squizani, A. M. C.; Marchi, T. M.; Bonacorso, H. G.; Martins, M. A. P. Bioorg. Med. Chem. 2006, 14, 3174.

185. (a) Reddy, A. C. S.; Rao, P. S.; Venkataratnam, R. V. Tetrahedron Lett. 1996, 37, 2845. (b)

Reddy, A. C. S.; Rao, P. S.; Venkataratnam, R. V. Tetrahedron 1997, 53, 5847.

186. (a) Bonacorso, H. G.; Marques, L. M. L.; Zanatta, N.; Martins, M. A. P. Synth. Comm. 2002, 32, 3225. (b) Nenajdenko, V. G.; Sanin, A. V.; Balenkova, E. S. Khim. Geterotsikl. Soedin. 1994, 1240.

187. (a) Bonacorso, H. G.; Lourega, R. V.; Deon, E. D.; Zanatta, N.; Martins, M. A. P. Tetrahedron Lett. 2007, 4835. (b) Bonacorso, H. G.; Lourega, R. V.; Righi, F. J.; Deon, E. D.; Zanatta, N.; Martins, M. A. P. J. Het. Chem., 2008, 1679.

188. Bonacorso, H. G.; Marques, L. M. L.; Zanatta, N.; Martins, M. A. P. Synth. Comm. 2002, $32,3225$.

189. Arun Dutt, S. V.; Chalapathi Rao, C. V. J. Fluorine Chem. 1996, 79, 7.

190. Pryadeina, M. V.; Burgart, Ya. V.; Saloutin, V. I.; Kodess, M. I.; Ulomskii, E. N.; Rusinov, V. L. Russ. J. Org. Chem. 2004, 40, 902.

191. Kuznetsova, O. A.; Filyakova, V. I.; Pashkevich, K. I.; Ulomskii, E. N.; Plekhanov, P. V.; Rusinov, G. L.; Kodess, M. I.; Rusinov, V. L. Russ. Chem. Bull. 2003, 52, 1190.

192. Desenko, S.; Gladkov, E. S.; Nenaidenko, V. G.; Shishkin, O. V.; Shishkinam S. V. Chem. Het Comp. 2004, 40, 65. 
193. Emelina, E. E.; Petrov, A. A. Russ. J. Org. Chem., 2009, 45, 417.

194. Takahashi, M.; Nagaoka, H.; Inoue, K. J. Het. Chem. 2004, 41, 525.

195. Reddy, A. C. S.; Narsaiah, B.; Venkataratnam, R. V. J. Fluorine Chem. 1997, 86, 127.

196. (a) Kacharova, L. M.; Gerus, I. I.; Kacharov, A. D. J. Fluorine Chem. 2002, 117, 193. (b) Zhu, S. -Z.; Qin, C. -Y.; Wang, Y. -L.; Chu, Q. -L. J. Fluorine Chem. 1999, 99, 183.

197. Krasovsky, A. L.; Nenajdenko, V. G.; Balenkova, E. S. Synthesis 2002, 1379.

198. (a) Krasovsky, A. L.; Hartulyari, A. S.; Nenajdenko, V. G.; Balenkova, E. S. Synthesis 2002, 133. (b) Krasovsky, A. L.; Moiseev, A. M.; Nenajdenko, V. G.; Balenkova, E. S. Synthesis 2002, 901.

199. Krasovsky, A. L.; Moiseev, A. M.; Nenajdenko, V. G.; Balenkova, E. S. Chem. Het. Comp. 2002, 38, 231.

200. Krasovsky, A. L.; Moiseev, A. M.; Nenajdenko, V. G.; Balenkova, E. S. Chem. Het. Comp. 2004, 40, 667.

201. Nikishin, K. G.; Nesterov, V. N.; Kislyi, V. P.; Shestopalov, A. M.; Semenov, V. V. Russ. Chem. Bull. 1998, 47, 679.

202. (a) Baraznenok, I. L.; Nenajdenko, V. G.; Balenkova, E. S. Chem. Het. Comp. 2003, 39, 776. (b) Baraznenok, I. L.; Nenajdenko, V. G.; Balenkova, E. S. Tetrahedron, 2000, 56, 3077. 


\section{Authors' Biographies}

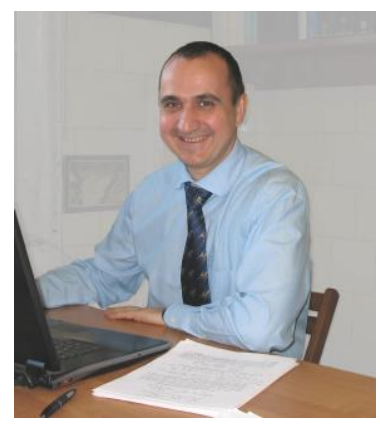

Valentine G. Nenajdenko was born in 1967 in Ivanovo, Russia. He graduated from Moscow State University (Lomonosov) in 1991. He received his Ph.D. degree under the supervision of Professor E.S. Balenkova in 1994 researching the synthesis and application of unsaturated $\mathrm{CF}_{3}$ ketones. In 2000 he received Dr. of Chemistry degree involving the chemistry of sulfonium and iminium salts. In 2003 he became full Professor of Organic Chemistry at the Department of Chemistry of Moscow State University. His scientific interests include organic synthesis, asymmetric catalysis, the chemistry of sulfur and fluorine containing compounds, heterocyclic chemistry, multicomponent reactions. He have been a supervisor of 13 postgraduate studies. Prof. Nenajdenko is head of the Scientific Committee and Jury of International Mendeleev Chemistry Olympiad. He was the winner of the Academiae Europeae Award in 1997, the Russian President Award in 1996, the Prize for the best scientific work at the Department of Chemistry of Moscow State University in 2001 and 2007, the Shuvalov Award in 2001, the Russian President Award in 2004, Russian Science Support Foundation in 2005, Moscow State University Awards in 2006, 2007 and 2008.

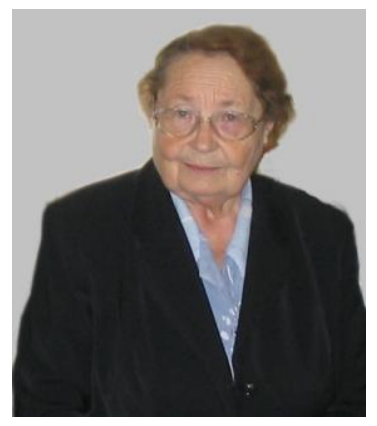

Elizabeth S. Balenkova was born in Moscow in 1926. She graduated from Moscow State University in 1950 and then she was a postgraduate student of the Department of Chemistry of Moscow State University. She received her Ph.D. degree under the supervision of academician B.A. Kazansky in 1953 for the research concerning medium ring hydrocarbons. Since that, she has been working at Moscow State University as a senior researcher (1959) and full professor (1986). She was a supervisor of 27 postgraduate and 63 diploma works. Her research interests are in the area of organic synthesis, electrophilic addition reaction, chemistry of heterocyclic and sulfur compounds. 